UNIVERSIDADE DE SÃO PAULO

FACULDADE DE ODONTOLOGIA

\title{
ESTUDO COMPARATIVO ENTRE DUAS TÉCNICAS PARA MONTAGEM DO MODELO DE GESSO DE ARCADAS SUPERIORES EM ARTICULADOR SEMI-AJUSTÁVEL
}

\section{ROGÉRIO RIBAS DA COSTA}

Tese apresentada à Faculdade de Odontologia da Universidade de São Paulo, para obter o Título de Doutor, pelo Programa de Pós-Graduação em Odontologia.

Área de Concentração: Prótese Dentária 
Data da Defesa: 20/11/ 2001.

\section{BANCA EXAMINADORA}

Prof. Dr.

Julgamento:

Assinatura:

Prof. Dr.

Julgamento:

Assinatura:

Prof. Dr.

Julgamento:

Assinatura:

Prof. Dr.

Julgamento:

Assinatura:

Prof. Dr.

Julgamento:

Assinatura: 
UNIVERSIDADE DE SÃO PAULO

FACULDADE DE ODONTOLOGIA

\section{ESTUDO COMPARATIVO ENTRE DUAS TÉCNICAS PARA MONTAGEM DO MODELO DE GESSO DE ARCADAS SUPERIORES EM ARTICULADOR SEMI-AJUSTÁVEL}

\section{ROGÉRIO RIBAS DA COSTA}

Tese apresentada à Faculdade de Odontologia da Universidade de São Paulo, para obter o Título de Doutor, pelo Programa de Pós-Graduação em Odontologia.

Área de Concentração: Prótese Dentária

Orientador: Prof. Dr. Artemio Luiz Zanetti 


\section{Catalogação-na-Publicação}

Serviço de Documentação Odontológica

Faculdade de Odontologia da Universidade de São Paulo

\section{Costa, Rogério Ribas da}

Estudo comparativo entre duas técnicas para montagem do modelo de gesso de arcadas superiores em articulador semi-ajustável / Rogério Ribas da Costa ; orientador Artemio Luiz Zanetti. -- São Paulo, 2001.

169 f. : il., tabs., grafs.

Tese (Doutorado - Programa Pós-Graduação em Odontologia. Área de Concentração: Prótese Dentária) -- Faculdade de Odontologia da Universidade de São Paulo.

1. Moldes dentários - Técnicas para montagem ajustável - Arcada superior 3. Prótese dentária
2. Articulador dentário semi-

CDD 617.69028

BLACK D37 


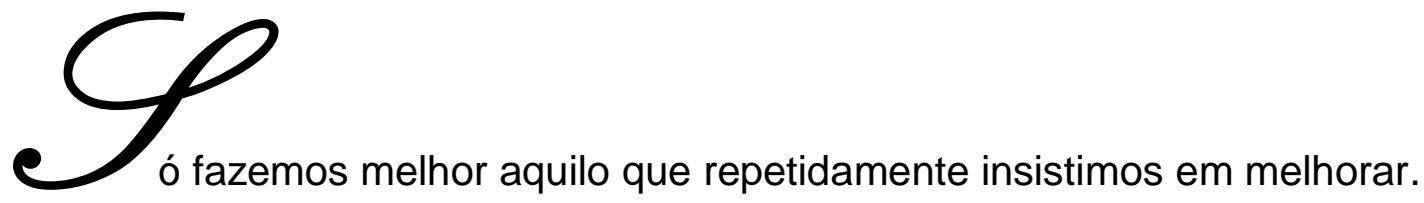

A busca da excelência não deve ser um objetivo e, sim, um hábito".

Aristóteles (384-322 a. C. ), filósofo grego 


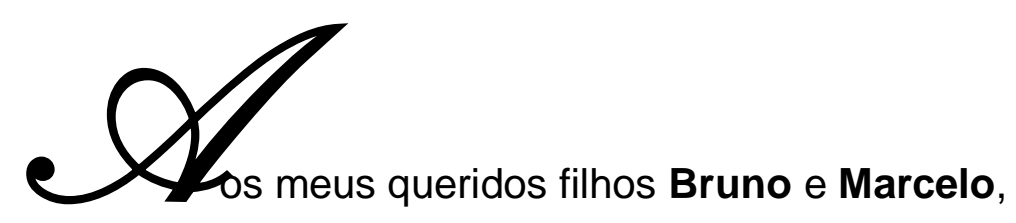

por todo amor que sinto, dedico carinhosamente esta obra. 


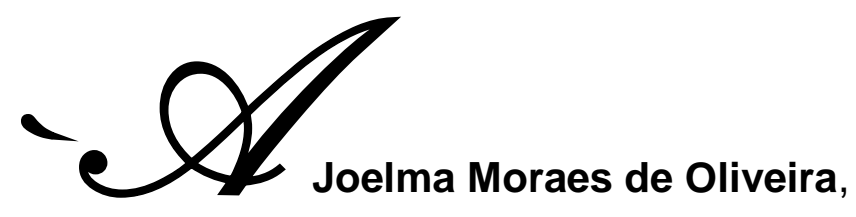

sem a qual a elaboração deste trabalho teria sido muito mais difícil, por todo seu amor, companheirismo, dedicação à profissão, incentivo, infinita paciência e compreensão. 
eos meus queridos Pais, Rosária e Roseny, pelo contínuo incentivo à minha vida profissional e aos estudos, dedico de modo muito especial esta obra. 


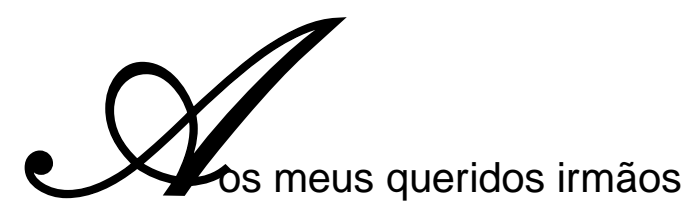

Renato, Ricardo, Raquel, Roberta e Rosane,

meus grandes amigos, e seus respectivos cônjuges e filhos, pelo amor, carinho e apoio sempre presentes. 


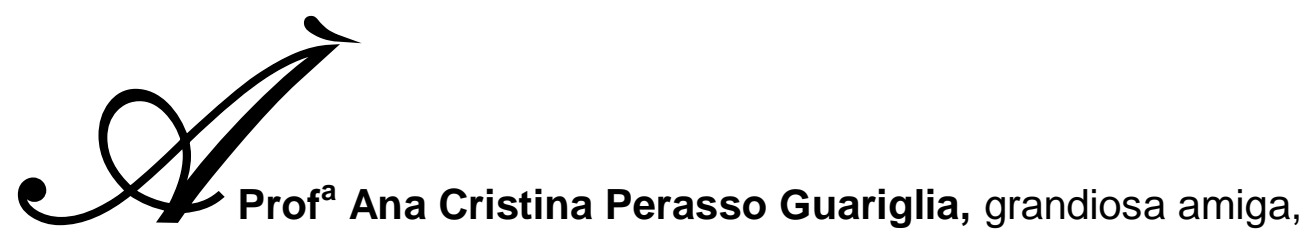

pela sua imensa amizade e consideração, confiança,

incentivo à atividade acadêmica e de pesquisa,

nosso eterno agradecimento. 


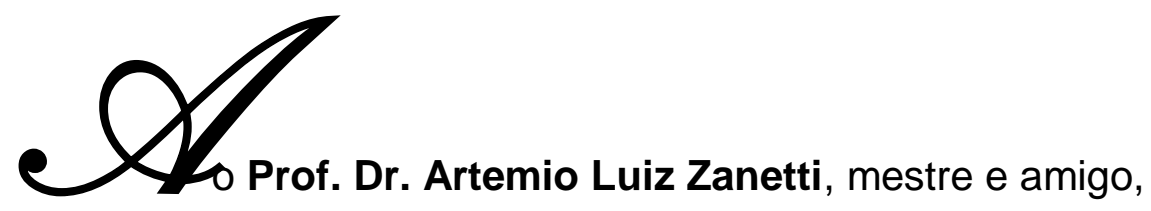

nosso reconhecimento pela confiança e consideração

que sempre nos dedicou e pela orientação prestimosa

na elaboração deste trabalho. 


\section{Ceus agradecimentos especiais são para os \\ profissionais que colaboraram}

neste trabalho:

$\mathrm{Na}$ fase clínica, nosso sincero e profundo reconhecimento pelos profissionais que engrandeceram o resultado final deste trabalho:

\begin{tabular}{||l|c|c||}
\hline \multicolumn{1}{|c|}{ NOME } & CRO & FONE \\
\hline 1. Alessandra Perasso & 53644 & $5084-4316$ \\
\hline 2. Alice B. de O. Schmidt & 68251 & $5042-0900$ \\
\hline 3. Ana Cristina P. Guariglia & 25318 & $5573-9419$ \\
\hline 4. Antonio Carlos Mauri Fo & 19167 & $246-9976$ \\
\hline 5. Joelma M. de Oliveira & 3625 & $5042-0900$ \\
\hline 6. José Virgílio de P. Eduardo & 7441 & $3813-8448$ \\
\hline 7. Patrícia Ferrara & 62594 & $5042-0900$ \\
\hline 8. Paulo G. Sanseverino Jr. & 45923 & $(12) 533-1302$ \\
\hline 9. Renata Pensado Ferraz & 65452 & $6335-5272$ \\
\hline 10.Rosana Pensado Ferraz & 36906 & $6335-4513$ \\
\hline
\end{tabular}

À Srt ${ }^{\mathrm{a}}$ Rosângela Monteiro, o nosso eterno agradecimento e respeito pela presteza, incentivo e carinho demonstrados na fase de desenvolvimento da metodologia utilizando o software Image Tool.

À Srt ${ }^{a}$ Adriana Sañudo, responsável pela análise estatística, pela atenção e consideração demonstrados, nosso sincero agradecimento.

À Sr $^{\mathrm{a}}$ Luzia Marilda Z. M. Moraes, do Serviço de Documentação Odontológica (SDO) da Faculdade de Odontologia da Universidade de São Paulo, nosso sincero agradecimento pelo trabalho de revisão da normalização das referências bibliográficas e das citações no texto.

Ao Sr. Roseny Ribas da Costa, nosso profundo reconhecimento e agradecimento pelo impecável trabalho de revisão final do texto e pelas prestimosas considerações e orientações. 


\section{PCus agradecimentos...}

..."são para aqueles que convivemos, que com pequenas atitudes, constroem a maior parte de nossa vida.

Ninguém deve viver isolado, porque ninguém é auto-suficiente.

As grandes alegrias merecem partilha".

(Autor desconhecido)

Ao Prof. Dr. Edmir Matson, Diretor da Faculdade de Odontologia da Universidade de São Paulo, pela atual administração.

À Chefe do Departamento de Prótese Dentária da Faculdade de Odontologia da Universidade de São Paulo, $\operatorname{Prof}^{\mathrm{a}} \mathbf{D r}^{\mathrm{a}}$ Maria Cecília Miluzzi Yamada pela atenção e compreensão prestadas desde o início de nosso Curso de Pós-Graduação.

Ao Prof. Dr. João Humberto Antoniazzi, Presidente da Comissão de PósGraduação da Faculdade de Odontologia da Universidade de São Paulo, pela importância e qualidade do curso oferecido, bem como pelos ensinamentos e pela amizade demonstrada.

Ao Prof. Dr. Moacyr Domingos Novelli, pela atenção e consideração que sempre nos prestou, pela sua imensa amizade e humildade na transmissão de sua grande sabedoria. Um exemplo a ser seguido.

À Faculdade de Odontologia da Universidade de São Paulo, pelas instalações onde se realizou o curso.

Aos Professores do Departamento Prótese Dental da Faculdade de Odontologia da Universidade de São Paulo, nas pessoas responsáveis pelas Disciplinas Prof $^{\mathrm{a}}$ Dr $^{\mathrm{a}}$ Maria Cecília Miluzzi Yamada (Prótese Total) - Prof. Dr. Tetsuo Saito (Prótese Parcial Fixa) - Prof. Dr. Carlos Gil (Prótese Parcial Removível), pelos ensinamentos e pela amizade demonstrada. 
Aos Professores do Curso de Pós-Graduação da Faculdade de Odontologia da Universidade de São Paulo, pelos ensinamentos ministrados e pela oportunidade da convivência técnico-científica durante o curso.

Às secretárias do Departamento de Prótese Dentária da Faculdade de Odontologia da Universidade de São Paulo, Sandra Maria Gomes da Silva, Valdinéia Barreto da Silva Santos, Coraci Aparecida de Moraes e, em especial, à secretária Regina de Carvalho Tognasoli, pela amizade, solicitude e compreensão que sempre prestaram.

Aos funcionários do Departamento de Prótese Dentária da Faculdade de Odontologia da Universidade de São Paulo, pela atenção que sempre prestaram durante o curso.

Às Sras. Cátia Tiezzi dos Santos, Nair Hatsuko Tanaka Costa e Emília Caetano Pereira do Serviço de Pós-Graduação pela atenção, paciência e por todas as orientações dadas.

Aos funcionários da Biblioteca da Faculdade de Odontologia da Universidade de São Paulo, pela atenção e auxílio prestados na elaboração deste trabalho.

A todos os colegas do Curso de Pós-Graduação e, em especial, à Marisol Castilla Camacho, pelas suas considerações no decorrer desse trabalho e pelos laços de amizade que nasceram no decorrer de nosso convívio.

Ao Sr. Sérgio Miglioli e demais funcionários da Casa das Teses, pela disponibilidade, gentileza e presteza na finalização deste trabalho.

À Universidade Cidade de São Paulo, nosso sincero agradecimento pela confiança depositada em nosso trabalho e, particularmente, à Faculdade de Odontologia, onde foi desenvolvida a fase clínica da pesquisa.

Ao Prof. Dr. Flávio Vellini Ferreira, Diretor da Faculdade de Odontologia da Universidade Cidade de São Paulo, por acreditar em nosso trabalho.

À Equipe de Prótese Dental da Faculdade de Odontologia da Universidade Cidade de São Paulo, nas pessoas responsáveis pelas Disciplinas - Prof. Dr. Antonio Carlos Mauri Filho (Prótese Total) - Prof. Dr. Ricardo Tatsuo Inoue (Prótese Parcial Fixa) - Prof $^{\mathrm{a}} \mathbf{D r}^{\mathrm{a}}$ Dalva Cruz Laganá (Prótese Parcial Removível), pelo incentivo, apoio e valiosa colaboração prestada.

Aos colegas do Centro de Estudos em Implantes Osseointegrados (CEIO) da Faculdade de Odontologia da Universidade Cidade de São Paulo, na pessoa de seu coordenador, Prof. Fábio Gonçalves, pela sua imensa amizade, atenção e consideração que sempre nos prestou.

Ao Prof. Dr. José Virgílio de Paula Eduardo, pela colaboração durante a elaboração desta obra. 
A todos os funcionários da Faculdade de Odontologia da Universidade Cidade de São Paulo, pelos prestimosos serviços prestados à Disciplina de Prótese Dentária.

Ao Jurandir Mariano de Oliveira, pela sua atenção, amizade e pelos valiosos trabalhos de computação gráfica.

À cirurgiã-dentista Alice Bernardes de Oliveira Schmidt pela sua valiosa cooperação durante execução desta investigação e pelos laços de amizade que nasceram no decorrer de nosso convívio.

Aos colegas cirurgiões-dentistas Igor Alexander Berenguel, Paulo Geraldo Sanseverino Junior e Rosana Ferraz Pensado pela consideração, amizade e vibração durante a elaboração deste trabalho, e também às auxiliares odontológicas Jeniffer Paulieli Lavado e Egle Pedroso Lavado pela inestimável colaboração.

Aos alunos Ana Carolina Lazzuri Alves Costa e Anderson Angelucci da F. O. UNICID, pelo auxílio prestado durante a execução da pesquisa, nosso sincero agradecimento.

À Sra. Maria Tereza Ribeiro, técnica do laboratório de Prótese Dental da Faculdade de Odontologia da Universidade Cidade de São Paulo, pelo auxílio durante a fase laboratorial da pesquisa.

Aos demais funcionários da Faculdade de Odontologia da Universidade de Cidade de São Paulo.

À Srta. Edvan de Souza Brito pela paciência, compreensão e inestimável auxílio.

À FAPESP - Fundação de Amparo à Pesquisa do Estado de São Paulo, pela concessão de bolsa de estudos. 


\section{SUMÁRIO}

p.

LISTA DE FIGURAS

LISTA DE TABELAS

LISTA DE GRÁFICOS

RESUMO

1 INTRODUÇÃO …...................................................................... 1

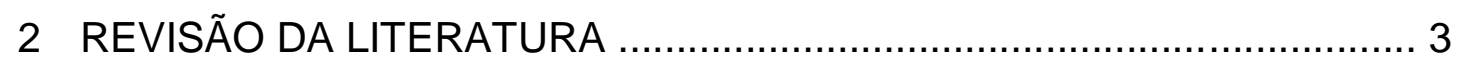

$2.1 \mathrm{O}$ problema da arcada parcialmente edentada ...................................... 3

2.1.1 Considerações gerais ............................................................ 3

2.1.2 Diferença de comportamento biomecânico dos sistemas de sustentação de carga encontrada numa Classe I de Kennedy ............. 5

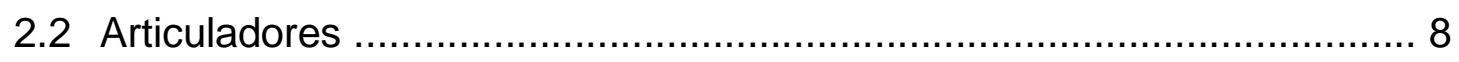

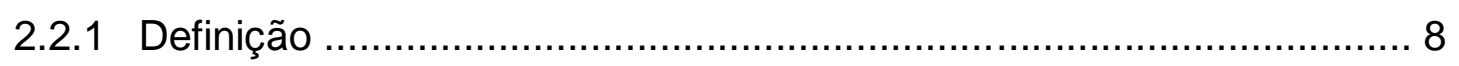

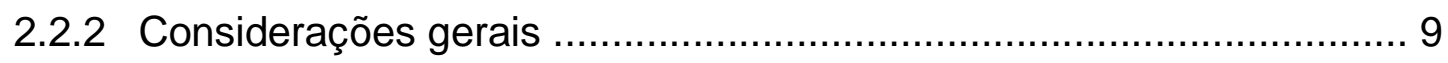

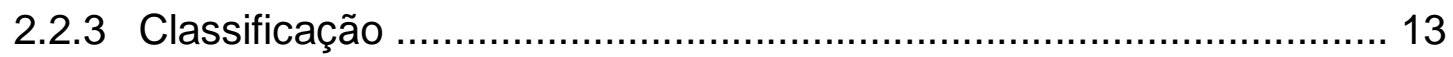

2.2.3.1 Articuladores simples ou não ajustáveis ................................... 21

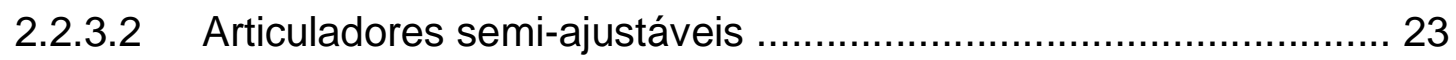

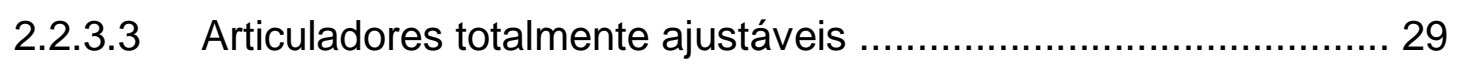

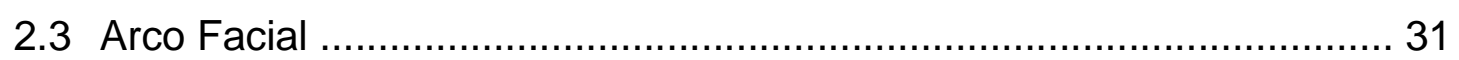

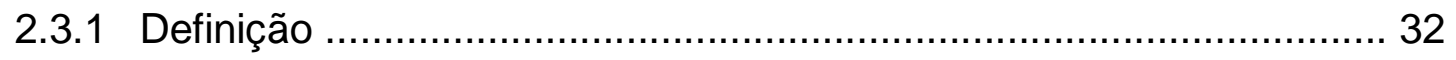

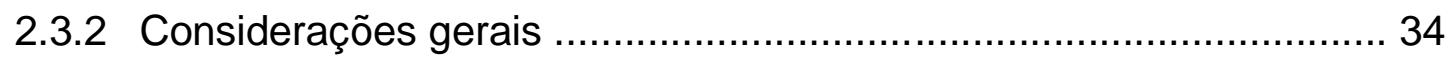

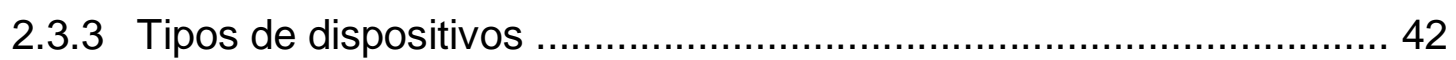

2.3.3.1 Arco facial arbitrário simples ................................................... 43

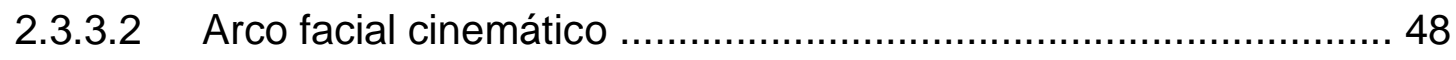

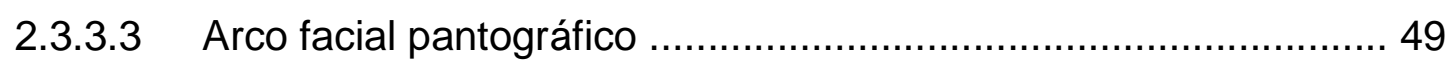




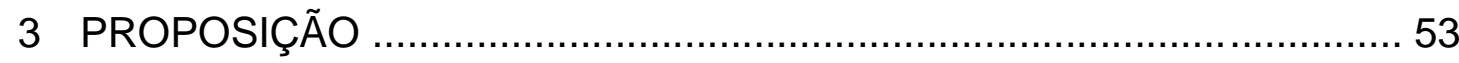

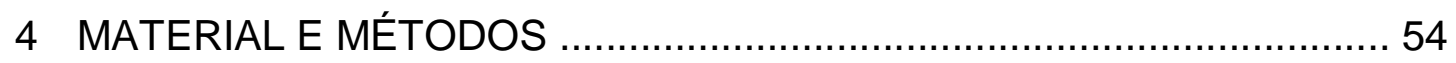

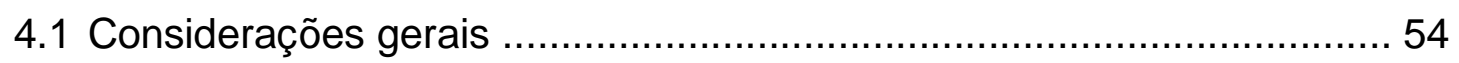

4.2 Treinamento e calibração dos operadores ………….......................... 57

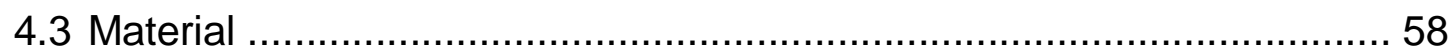

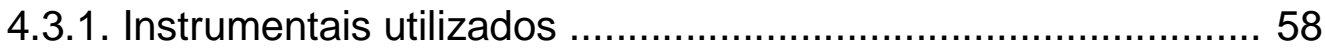

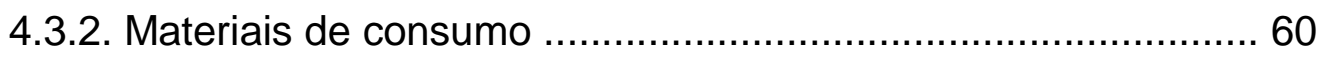

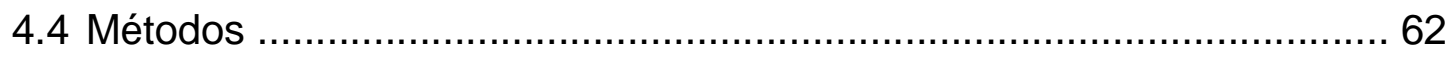

4.4.1 Metodologia utilizada para obtenção do modelo-padrão e preparo para

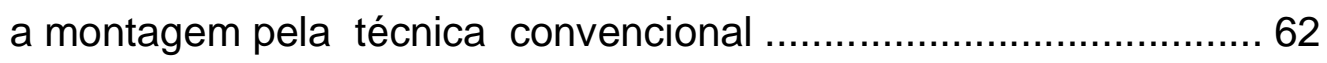

4.4.2 Metodologia para o ajuste do arco facial e montagem no articulador com a técnica convencional ........................................................ 73

4.4.3 Técnica de montagem direta no articulador ................................... 92

4.4.3.1 Sistema de transferência direta do molde .................................. 92

4.4.4 Metodologia para moldagem e montagem no articulador com a técnica de transferência direta (Técnica Zanetti) ....................................... 96

4.4.5 Metodologia para análise das imagens ..................................... 117

4.4.5.1 Obtenção e digitalização da telerradiografia em norma

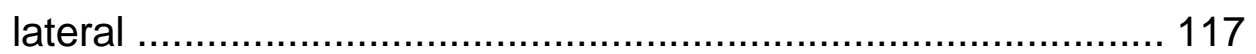

4.4.5.2 Digitalização das imagens dos modelos de gesso montados nos articuladores .................................................. 120

4.4.5.3 Análise das imagens no computador ...................................... 123

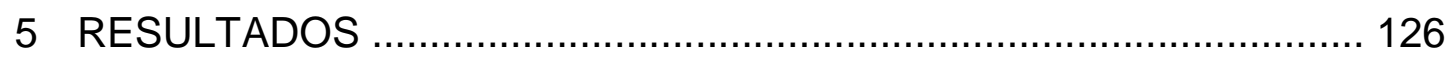

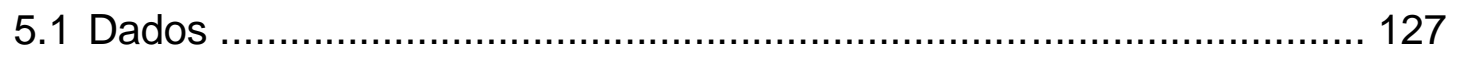

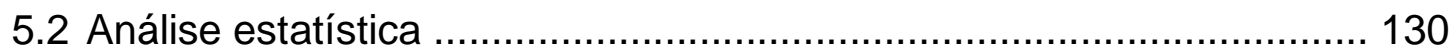

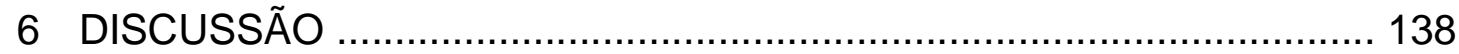

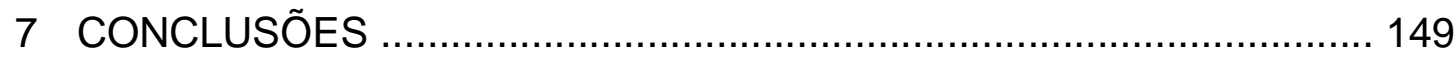

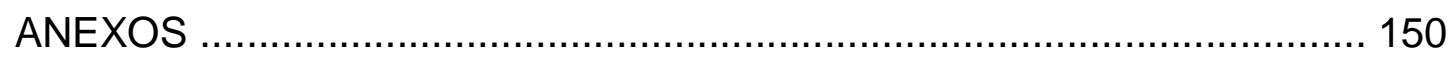

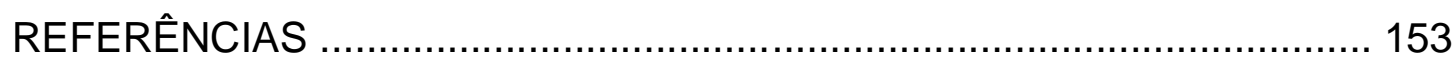

SUMMARY 


\section{LISTA DE FIGURAS}

Figura 2.1 - O modelo de gesso deve relacionar-se aos elementos mecânicos do articulador de maneira idêntica à maxila no contexto crânio facial 4

Figura 2.2 - Desequilíbrio biomecânico existente devido à presença de diferentes comportamentos entre dentes e fibromucosa frente às cargas mastigatórias (extraído do livro de Zanetti \& Laganá, 1996)

Figura 2.3 - Pfaff confeccionava uma escavação na extensão posterior do modelo inferior (seta) para poder articulá-lo com o superior (extraído do artigo de Huggett \& Harrison, 1977) ..................... 8

Figura 2.4 - Articulador do tipo arcon, onde os elementos mecânicos da articulação imitam a anatomia humana

Figura 2.5 - Articulador do tipo não-arcon: (1) elemento condilar no ramo superior e, (2) guia condilar no ramo inferior.

Figura 2.6 - Articulador Gysi Simplex concebido por Alfred Gysi em 1912 (extraído do artigo de Huggett \& Harrison, 1977)

Figura 2.7 - Articulador Dentatus idealizado por Beyron em 1944 na Suécia

Figura 2.8 - Charles Stuart idealizou em 1955 sua concepção de articulador totalmente ajustável (extraído do livro de Todescan et al., 1998)

Figura 2.9 - Articulador do tipo charneira (abre e fecha) 22

Figura 2.10 - Articulador arcon semi-ajustável Whip Mix 8500 24

Figura 2.11 - Articulador totalmente ajustável concebido por Tadachi Tamaki

Figura 2.12 - O arco facial arbitrário simples foi idealizado e patenteado por Snow e é essencialmente o mesmo utilizado hoje em dia (extraído do livro de Turano \& Turano, 1998) 
Figura 2.13 - O arco facial determina um plano de referência horizontal coincidente com o plano de Frankfurt, que vai do pórion (1) à porção inferior da cavidade orbital (2)

Figura 2.14 - (a) arco facial simples de posicionamento no meato acústico externo; (b) detalhe do dispositivo denominado de suporte anterior do arco facial (seta), que permite a manutenção da posição de registro da arcada superior para a montagem do modelo de gesso

Figura 2.15 - Arco facial cinemático acoplado a um clutch (setas) (extraído do livro de Todescan et al., 1998)

Figura 2.16 - Arco facial pantográfico: (a) puas registradoras posteriores;

(b) puas registradoras anteriores; (c) plataformas de registro posterior e, (d) plataformas de registro anterior

Figura 4.1 - Arcada superior de Classe I de Kennedy, utilizada na pesquisa

Figura 4.2 - Articulador arcon semi-ajustável com arco facial arbitrário simples utilizado na pesquisa

Figura 4.3 - Conjunto de moldeiras de transferência: (1) moldeiras;

(2) sistema de fixação da moldeira no arco facial e, (3) cabo para moldeira funcional de transferência

Figura 4.4 - Conjunto de suportes Ribas: suporte inferior da moldeira

(1) e suporte anterior do arco facial (2) 60

Figura 4.5 - Modelo-padrão utilizado para a duplicação dos modelos para a técnica convencional

Figura 4.6 - Após a obtenção dos moldes do modelo-padrão, os modelos foram duplicados: à esquerda o molde vazado

Figura 4.7 - Detalhe do molde de borracha de silicone para a duplicação dos modelos

Figura 4.8 - Detalhe de um modelo de gesso $C$ (convencional) obtido a partir do molde do modelo-padrão: (a) vista oclusal; (b) vista anterior;

(c) vista do lado direito e, (d) vista do lado esquerdo 68

Figura 4.9 - Plano de orientação com a curva antero-posterior confeccionada previamente pela placa conformadora de plano oclusal e, com uma altura posterior de $2,5 \mathrm{~cm}$ da base do modelo à superfície interna da placa 
Figura 4.10 - Melhoria da adaptação do plano de orientação no modelo com a aplicação da pasta de óxido de zinco e eugenol (base estabilizada)

Figura 4.11 - Plano de orientação recolocado na boca da paciente 75

Figura 4.12 - Colocação do garfo com godiva e pasta de óxido de zinco e eugenol, para o registro da posição da arcada superior da paciente

Figura 4.13 - Colocação do arco facial iniciando pela introdução da união Universal no cabo do garfo (seta)

Figura 4.14 - Aperto dos três parafusos superiores do arco facial (setas) 78

Figura 4.15 - Colocação do násion (a) no suporte geral do arco facial (b) 79

Figura 4.16 - Aperto da união universal do eixo principal do arco facial (seta) 80

Figura 4.17 - Aperto da união universal que fixa o cabo do garfo ao arco facial (seta)

Figura 4.18 - Após a remoção do arco facial da face da paciente, deve-se colocar a banda elástica ao redor do arco

Figura 4.19 - Para que o arco facial passe pelo centro de rotação dos elementos condilares (linha a) e, desta forma, fique paralelo ao ramo superior do articulador (plano de Frankfurt), as guias condilares devem ser ajustadas inicialmente em $30^{\circ}$ (linha $b$ )

Figura 4.20 - Guia condilar regulada em $0^{\circ}$. Observar que o arco facial montado dessa forma não passaria pelo centro de rotação do elemento condilar (linha) e também não permitiria seu paralelismo com o ramo superior do articulador

Figura 4.21 - Suporte inferior do garfo posicionado no ramo inferior do articulador

Figura 4.22 - Ajuste das guias do movimento lateral (Bennett) com angulação negativa para facilitar o manuseio do ramo superior do articulador (setas)

Figura 4.23 - Colocação do modelo de gesso no garfo do arco facial. A seta a mostra o suporte anterior; A seta $b$ mostra o suporte inferior do garfo 
Figura 4.24 - Colocação do gesso primeiramente na placa de montagem superior

Figura 4.25 - O gesso é colocado na base do modelo após a placa superior do articulador

Figura 4.26 - O gesso deve ser espalhado sobre as retenções da base do modelo

Figura 4.27 - Após a colocação do gesso para fixação do modelo, abaixa-se o ramo superior tomando-se o cuidado de posicionar corretamente a banda elástica (seta)

Figura 4.28 - Uma pequena quantidade de gesso (seta) é suficiente para garantir a fixação inicial do modelo e impedir os efeitos da expansão de cristalização do gesso 90

Figura 4.29 - Modelo de gesso montado pela técnica convencional. Observar a utilização do suporte anterior do arco facial (1) e o suporte inferior do garfo (2) para garantir a correta posição do modelo no articulador de maneira idêntica àquela ocupada pela maxila da paciente

Figura 4.30 - Uma nova camada de gesso foi colocada para aumentar a resistência de fixação do modelo ao articulador, completando o acabamento final do modelo de gesso montado com a técnica convencional

Figura 4.31 - Detalhe do sistema de fixação da moldeira de transferência (vista superior): (1) presilha superior; (2) conexão posicionadora inferior; (3) sistema de encaixe angular e, (4) posicionador da moldeira de transferência

Figura 4.32 - Detalhe do sistema de fixação da moldeira de transferência (vista lateral esquerda): (1) presilha superior; (2) conexão posicionadora inferior; (3) sistema de encaixe angular e, (4) posicionador da moldeira de transferência

Figura 4.33 - Detalhe do sistema de fixação da moldeira de transferência (vista inferior): (1) parafuso convencional transfixador; (2) parafuso de fixação do posicionador da moldeira; (3) sistema de encaixe angular com duplo plano inclinado e, (4) parafuso independente para fixação do cabo da moldeira

Figura 4.34 - Individualização da moldeira de transferência finalizada 98

Figura 4.35 - Para garantir a retenção do alginato deve-se fazer retenções em toda a extensão da cera 
Figura 4.36 - Sequência de montagem do arco facial pela técnica de transferência direta: (a) moldagem da arcada superior; (b) colocação do posicionador da moldeira; (c) colocação do arco facial e, (d) aperto dos 3 parafusos da parte superior do arco

Figura 4.37 - Colocação do suporte nasal ou nasion (seta) 101

Figura 4.38 - Aperto do parafuso da união universal do suporte principal do arco facial (seta), tomando-se o cuidado de manter a estabilidade do arco com a outra mão

Figura 4.39 - Aperto do parafuso transfixador da conexão posicionadora Inferior (seta)

Figura 4.40 - Aperto do parafuso do posicionador da moldeira (a); não é necessário nessa fase apertar o parafuso independente de fixação da haste da moldeira $(b)$

Figura 4.41 - Observar o correto posicionamento do arco facial em relação ao plano de referência horizontal (plano de Frankfurt) 104

Figura 4.42 - (a) remove-se o suporte nasal; (b) afrouxa-se os parafusos da parte superior do arco; $(c)$ desaloja-se as olivas dos meatos acústicos externos e, $(d)$ desliza-se a conexão inferior pelo cabo da moldeira até soltar-se totalmente da mesma

Figura 4.13 - Moldeira de transferência com o posicionador (seta) fixado em seu cabo

Figura 4.44 - Remoção da moldeira de transferência 106

Figura 4.45 - Colocação correta da banda elástica (a); ajuste dos suportes inferior da moldeira $(b)$ e, anterior do arco facial $(a)$

Figura 4.46 - Vazamento do molde sob vibração. Observar que o posicionador da moldeira de transferência permanece no cabo da mesma, mantendo o registro de sua posição original na boca

Figura 4.47 - (a) colocação do conjunto molde vazado+moldeira de transferência no arco facial; (b) o parafuso independente da conexão inferior é apertado para fixar o cabo precisamente no arco; (c) colocação do arco no ramo superior e, (d) colocação do suporte anterior do arco 109

Figura 4.48 - Coloca-se o gesso primeiramente na placa de montagem superior 
Figura 4.49 - Na sequência, coloca-se o gesso sobre a porção previamente vazada do molde

Figura 4.50 - Levanta-se a banda elástica e abaixa-se o ramo superior

Figura 4.51 - O ramo superior deve encostar completamente sobre o suporte geral do arco facial

Figura 4.52 - A banda elástica é aplicada sobre o ramo superior do articulador

Figura 4.53 - Foi colocada uma pequena quantidade de gesso suficiente para complementar a fixação do futuro modelo no articulador

Figura 4.54 - Modelo de gesso montado em articulador pela técnica de transferência direta (Técnica Zanetti)

Figura 4.55 - (a) término da confecção dos modelos convencionais e de transferência direta (Zanetti); (b) detalhe do modelo convencional e, $(c)$ detalhe do modelo obtido pela técnica Zanetti

Figura 4.56 - (a) montagem dos modelos nos articuladores e, (b) no detalhe, os modelos da técnica Zanetti prontos para serem fotografados nos articuladores

Figura 4.57 - Telerradiografia em norma lateral tomada com o arco facial em posição na face da paciente. Todo cuidado foi dado para que não ocorresse um erro de paralaxe em relação ao arco

Figura 4.58 - Telerradiografia em norma lateral digitalizada com os traçados dos planos de referência horizontal (arco facial) e oclusal com a intersecção sobre o arco (a) e régua de calibragem de $1 \mathrm{~cm}(b)$

Figura 4.59 - Imagem digitalizada mostrando a intersecção dos traçados na borda esquerda da fotografia (a) e a régua de calibragem de $1 \mathrm{~cm}$ aplicada sobre o ramo superior do articulador $(b)$

Figura 4.60 - Imagem digitalizada da telerradiografia em norma lateral sendo analisada pelo software Image Tool, após a calibragem espacial

Figura 4.61 - Imagem digitalizada do modelo de gesso sendo analisada pelo software Image Tool, após a calibragem para correção da magnificência entre a telerradiografia e as fotografias 


\section{LISTA DE TABELAS}

Tabela 5.1 - Ângulo (em graus) formado entre o plano oclusal e o de Frankfurt, segundo a telerradiografia em norma lateral da paciente

Tabela 5.2 - Ângulo (em graus) formado entre o plano oclusal e o ramo superior (plano de Frankfurt) do articulador, segundo os modelos montados pela técnica convencional

Tabela 5.3 - Ângulo (em graus) formado entre o plano oclusal e o ramo superior (plano de Frankfurt) do articulador, segundo os modelos montados pela técnica de transferência direta 


\section{LISTA DE GRÁFICOS}

Gráfico 5.1 - Gráfico de dispersão dos resíduos segundo os modelos da técnica convencional

Gráfico 5.2 - Gráfico de dispersão dos resíduos segundo os modelos da técnica de transferência direta

Gráfico 5.3 - Gráfico de dispersão dos valores médios dos modelos da técnica convencional

Gráfico 5.4 - Gráfico de dispersão dos valores médios dos modelos da técnica de transferência direta

Gráfico 5.5 - Gráfico de barras das diferenças entre os valores obtidos da telerradiografia e os obtidos pela técnica convencional segundo cada modelo

Gráfico 5.6 - Gráfico de barras das diferenças entre os valores obtidos da telerradiografia e os obtidos pela técnica de transferência direta segundo cada modelo

Gráfico 5.7 - Representação gráfica do intervalo de confiança a 95\% para cada uma das técnicas avaliadas 


\section{ESTUDO COMPARATIVO ENTRE DUAS TÉCNICAS PARA MONTAGEM DO MODELO DE GESSO DE ARCADAS SUPERIORES EM ARTICULADOR SEMI-AJUSTÁVEL}

Este estudo avaliou a habilidade de duas técnicas, uma convencional e uma de transferência direta do molde, para a montagem do modelo de gesso maxilar no articulador. Um único paciente do sexo feminino, 39 anos, portador de arcada superior de Classe I de Kennedy (desdentado posterior bilateral) foi usado para esta investigação. Foram obtidos 20 modelos de gesso em cada técnica, totalizando 40 montagens nos articuladores. Com o modelo maxilar montado, cada articulador foi fotografado do mesmo lado direito da radiografia em norma lateral da paciente, obtida com o arco facial montado em sua face. As medidas analisadas nos traçados realizados sobre as fotografias e na radiografia, foram obtidas calculando-se o ângulo entre a interseção do plano oclusal da maxila e o plano de referência horizontal (plano de Frankfurt), representado pelo arco facial na radiografia da paciente, comparando-o com o ângulo entre o plano oclusal do modelo de gesso e o ramo superior do articulador em ambas as técnicas, por meio do software UTHSCSA Image Tool. O dados foram submetidos à análise estatística. Os resultados deste estudo demonstraram uma capacidade maior de reprodução daquele ângulo quando uma técnica de transferência direta do molde é usada. Da mesma maneira, foi verificado uma distorção significante na reprodutibilidade dos modelos montados pela técnica convencional. 


\section{INTRODUÇÃO}

Para se elaborar uma análise oclusal ou mesmo um adequado plano de tratamento de qualquer caso em Odontologia, necessita-se de uma tríade formada pelo exame clínico, exame radiográfico e modelos de gesso de ambas as arcadas correlatados de maneira adequada.

A primeira tentativa de se examinar o relacionamento maxilomandibular ocorreu em 1756 com Phillip Pfaff, dentista de Frederico o Grande, da Prússia, que articulava os modelos de gesso superior e inferior com finalidade diagnóstica.

Compulsando-se a literatura verifica-se que os trabalhos de pesquisa procuram demonstrar, desde então, a melhor forma de estabelecer uma relação entre a maxila e a mandíbula, com o objetivo de permitir um correto diagnóstico, plano de tratamento e execução de qualquer tratamento reabilitador. Os pesquisadores são unânimes em corroborar a necessidade de montagem dos modelos de gesso no articulador na mesma posição espacial tridimensional que a arcada superior ocupa no paciente.

$\mathrm{O}$ articulador é um dos principais instrumentos utilizados na Odontologia para esse propósito no qual, ao relacionar os modelos de gesso de forma precisa, conseguese simular ou reproduzir os movimentos mandibulares.

Profissionais e estudantes de Odontologia rotineiramente se deparam com a exigência de se montar apropriadamente os modelos de gesso em articuladores. 
A literatura mostra que quando se aplicam os procedimentos convencionais de montagem, mesmo nos casos de arcadas totalmente dentadas, poderão ocorrer alterações de posição do modelo de gesso no articulador, causadas devido às alterações dimensionais dos diversos materiais utilizados para esse procedimento, que tornarão imprecisos o diagnóstico, o plano de tratamento e a construção de uma prótese dental.

Sem dúvida nenhuma essas distorções são mais evidentes quando se trata de uma arcada parcialmente edentada de extremidade livre (espaços protéticos posteriores uni ou bilaterais), devido a presença de dois sistemas de suporte de carga com comportamentos biomecânicos diferentes - dente e fibromucosa. Essa situação obrigatoriamente exige a confecção de planos de orientação para obtenção do tripodismo necessário à montagem desses modelos em articulador.

Com a utilização de um sistema de transferência direta do molde, consegue-se registrar e transferir a posição da arcada superior do paciente para o articulador numa só etapa, sem a necessidade de confeccionar-se as bases de prova ou de registro e planos de orientação, do garfo do arco facial e dos meios macios de transferência.

Comparando-se clinicamente essas duas técnicas foi possível verificar qual delas apresenta uma maior capacidade de montagem do modelo de gesso superior em relação aos elementos mecânicos do articulador, da mesma maneira que a arcada superior se relaciona ao contexto crânio-facial do paciente. 


\section{REVISÃO DA LITERATURA}

O presente estudo irá comparar duas técnicas de montagem de modelos de gesso, para verificar a capacidade de precisão de cada uma em relação a reprodução da posição da arcada superior do paciente no articulador semi-ajustável, que utiliza o arco facial arbitrário simples. Para facilitar o entendimento da pesquisa, a revisão da literatura será conduzida no sentido de abordar separadamente os seguintes tópicos: (1) o problema da arcada parcialmente edentada; (2) articuladores e, (3) arco facial.

\subsection{O problema da arcada parcialmente edentada}

\subsubsection{Considerações gerais}

Na Prótese Dental, como em qualquer outra especialidade odontológica, para a reabilitação de uma arcada parcialmente edentada é necessário montar-se os modelos de gesso do paciente de forma apropriada no articulador (Pruden, 1960; Ellis III et al., 1992).

Vários pesquisadores demonstraram que se os modelos de gesso não forem montados de forma correta, os dentes ocluirão no articulador em posição diferente daquela encontrada na boca do paciente. É indispensável que o modelo de gesso da arcada superior esteja precisamente montado no articulador, numa relação espacial 
similar à posição tridimensional que a maxila ocupa no paciente em relação aos ossos do crânio (Figura 2.1), a fim de capacitar a reprodução exata do relacionamento maxilomandibular (Weinberg, 1963a; Whitsett et al., 1977; Henderson \& Steffel, 1979; Shillingburg et al., 1983; Zuckerman, 1985, Zanetti \& Laganá, 1996; Zanetti \& Ribas, 1996, 1997; Costa, 1998 e Costa et al., 1999).

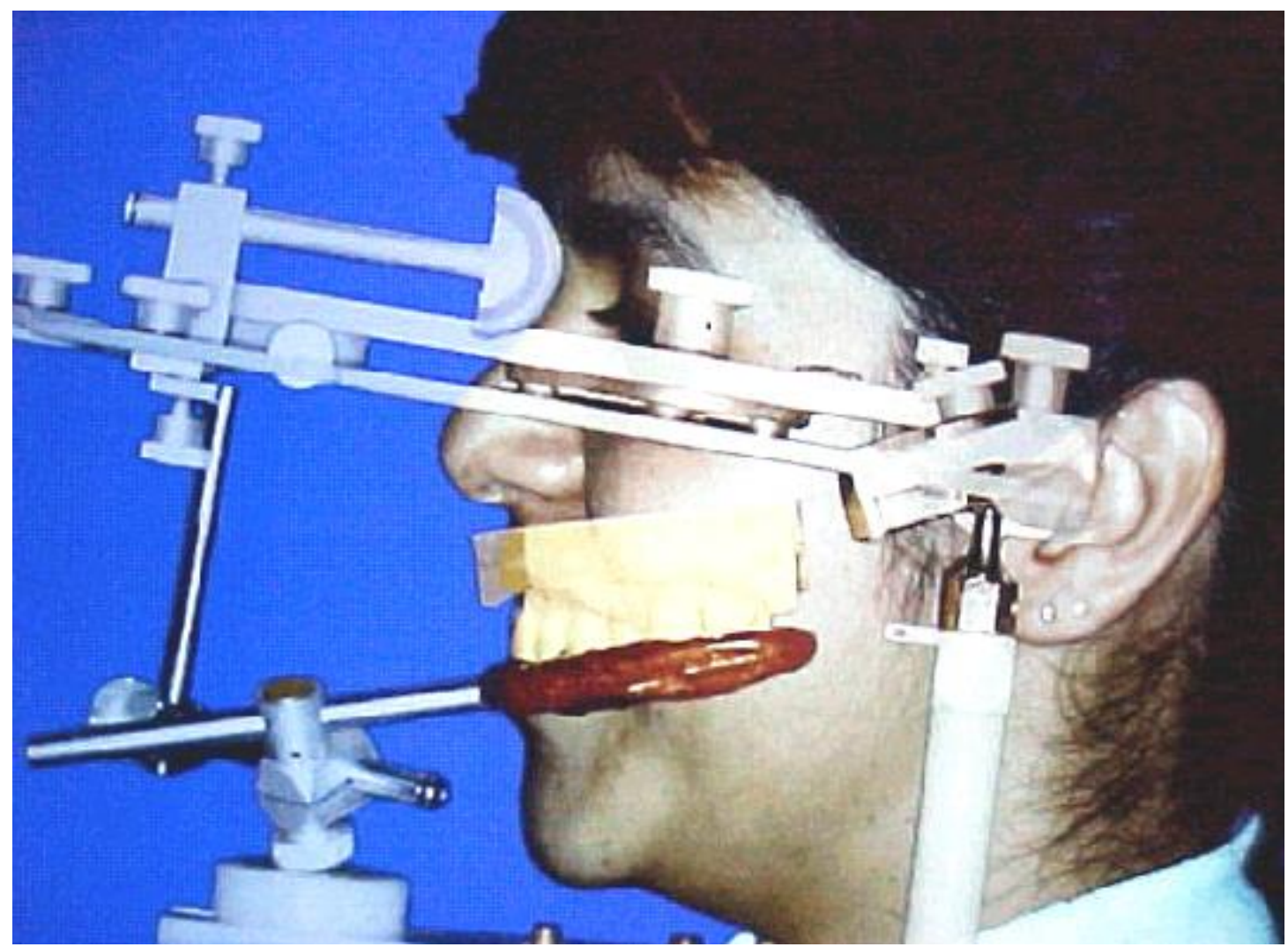

Figura 2.1 - 0 modelo de gesso deve relacionar-se aos elementos mecânicos do articulador de maneira idêntica à maxila no contexto crânio facial 
Dependendo do grau de complexidade que uma arcada parcialmente edentada possa apresentar, a montagem de modelos em articulador será igualmente complexa, como por exemplo, as arcadas que apresentam grandes espaços edentados, e mesmo aquelas totalmente dentadas que apresentam um grau de mobilidade acentuado devido à patologias periodontais.

As arcadas que apresentam grandes espaços protéticos ou extremidades livres, uni ou bilaterais, apresentam um grau de complexidade muito grande na construção de próteses adequadas, devido a presença de duas vias de suporte, de naturezas diferentes, na sua sustentação: uma dentária, representada pelas fibras periodontais e outra fibromucosa, representada pela resiliência dos tecidos que recobrem o rebordo alveolar. Diversos pesquisadores mencionaram a diferença de comportamento entre dentes e fibromucosa diante das forças mastigatórias (Henderson \& Steffel, 1979; Zanetti \& Laganá, 1996; Zanetti \& Ribas, 1996).

\subsubsection{Diferença de comportamento biomecânico dos sistemas de sustentação de carga encontrada numa Classe I de Kennedy}

Thielemann (1938) citado por Rebossio (1963) e Biagi \& Elbrech (1955) demonstraram que os dentes sofrem uma movimentação fisiológica para dentro do alvéolo de $0,1 \mathrm{~mm}$.

Fava (1956) registrou o valor médio de resiliência da fibromucosa em torno de uma grandeza correspondente a 1,3mm. Isto significa que a fibromucosa confere uma 
liberdade de movimentos à base da prótese 13 vezes maior que aquela permitida pelos dentes, condicionados ao confinamento de seus alvéolos.

Segundo Applegate (1959) e Henderson \& Steffel (1979) o problema maior em próteses dento-mucoso-suportadas, são as duas citadas vias de transmissão (dente e fibromucosa), pois que ambas têm comportamentos diferentes frente às cargas mastigatórias.

Rebossio (1963); Zanetti \& Laganá (1996); Zanetti \& Ribas (1996) e Todescan et al. (1998) também citaram em seus trabalhos o desequilíbrio biomecânico que ocorre com próteses de extremidade livre, devido à diferença de comportamento biomecânico entre dentes e fibromucosa, pois além da movimentação fisiológica dos dentes para dentro do alvéolo, existe uma deformação da fibromucosa diante de cargas mastigatórias que variam em média de 1 a 3mm. Concluíram os autores que "se a fibromucosa se deforma em média de 1 a $3 \mathrm{~mm}$ e os dentes de suporte movimentam-se em até 0,1mm, é certo que haverá um desequilíbrio biomecânico". Segundo Todescan et al. (1998) os registros encontrados na literatura vão de 0,4 até 3 e $4 \mathrm{~mm}$, estes últimos para os casos de fibromucosa muito flácida. Portanto esse desequilíbrio biomecânico pode chegar até 20, 30 ou 40 vezes mais (Figura 2.2). 


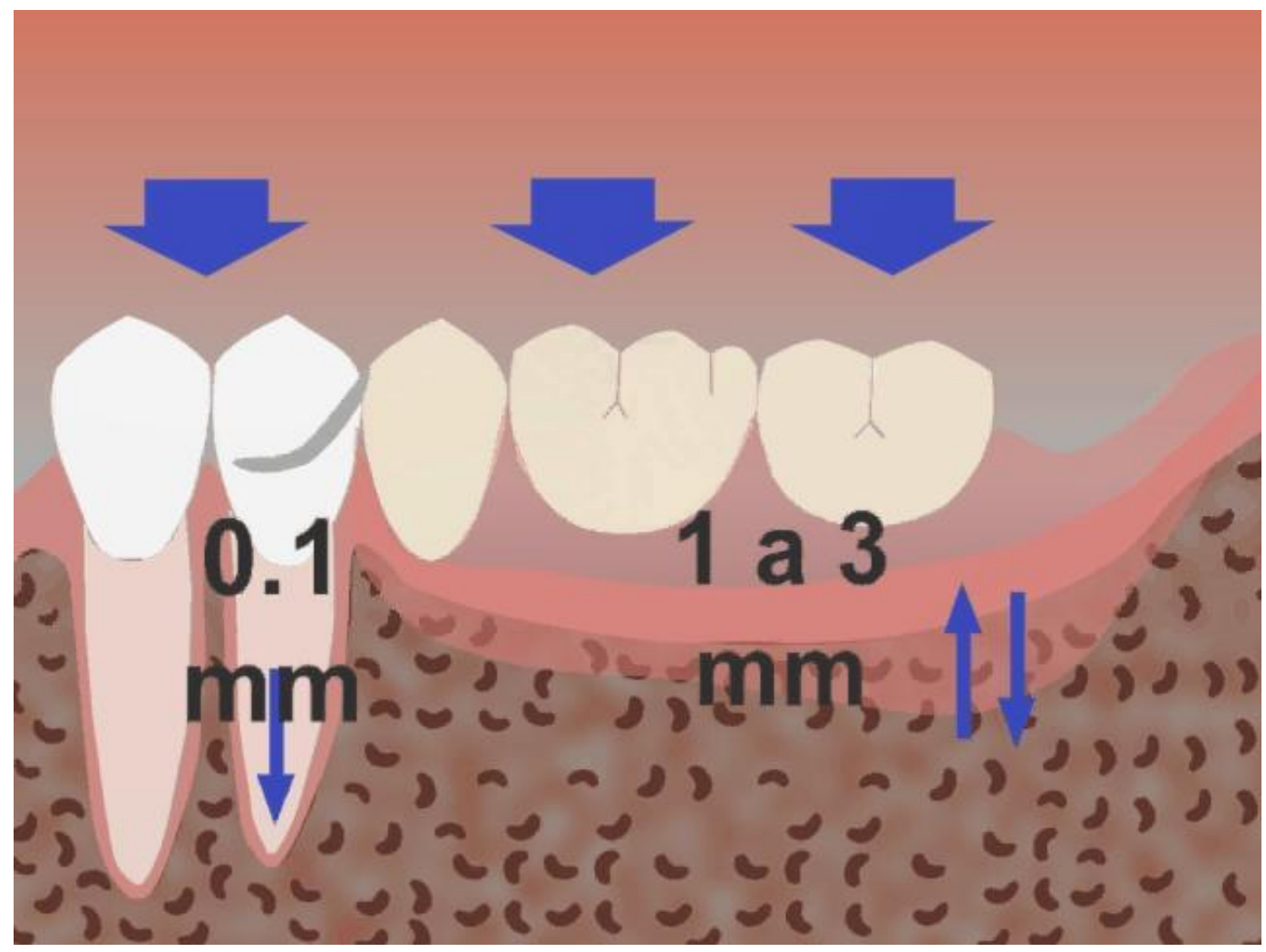

Figura 2.2 - Desequilibrio biomecânico existente devido à presença de diferentes comportamentos entre dentes e fibromucosa frente às cargas mastigatórias (extraído do livro de Zanetti \& Laganá, 1996)

De acordo com os trabalhos de Smutko (1977) e Shillingburg et al. (1983) sabe-se que para uma melhor biocompatibilidade entre a prótese e os elementos dentais e tecidos subjacentes, é fundamental que a transferência das informações da boca do paciente para o articulador seja feita sem distorções, e de maneira precisa e simplificada. Esse fato evidencia a grande importância de se obter um equilíbrio de comportamento biomecânico entre esses dois sistemas de suporte, já na fase de moldagem e montagem dos modelos de gesso no articulador. 


\subsection{Articuladores}

\subsubsection{Definição}

O desenvolvimento e a evolução dos articuladores, como também, qual teria sido o primeiro articulador construído com a finalidade de auxiliar na reabilitação de arcadas parcialmente edentadas, constituem questões bastante controvertidas na literatura. Existe uma vasta quantidade de trabalhos, elaborados por centenas de pesquisadores os quais, desde a primeira tentativa de relacionar a maxila e a mandíbula feita, segundo Mitchell \& Wilkie (1978), por Phillip Pfaff em 1756, vêm tentando interpretar os complexos movimentos mandibulares e entender o trabalho e a função da articulação temporomandibular (Figura 2.3).

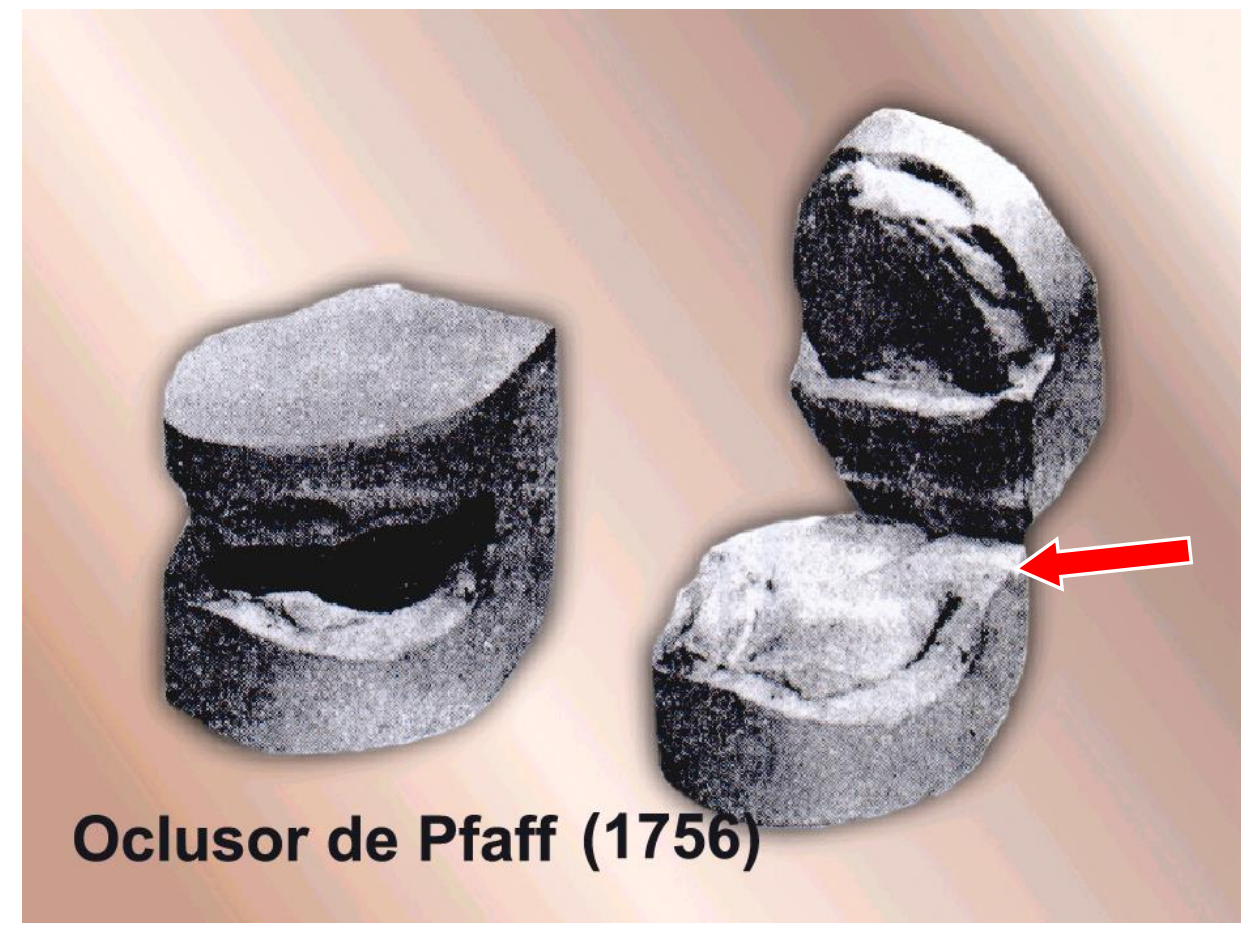

Figura 2.3 - Pfaff confeccionava uma escavação na extensão posterior do modelo inferior (seta) para poder articulá-lo com o superior (extraído do artigo de Huggett \& Harrison, 1977)

Segundo Santos Jr. (2000, informação verbal) os articuladores são instrumentos que melhor seriam denominados de simuladores, pois, na verdade, são 
utilizados para simular os movimentos mandibulares, bem como, as relações maxilomandibulares das arcadas dentárias. Tendo em vista suas finalidades primordiais, é importante levar-se em conta que a estrutura e dimensão de um instrumento sejam compatíveis com as do aparelho mastigatório. Um aspecto muito importante na aceitação e uso de articuladores, por parte dos profissionais, estaria ligada à simplicidade do manuseio e precisão nos ajustes dos instrumentos.

Por definição, de acordo com Pruden (1960); Weinberg (1963a); Hickey et al. (1967); Heartwell \& Rahn (1974); Henderson \& Steffel (1979); Tamaki (1981); Zanetti \& Ribas (1996, 1997); Costa (1998); Todescan et al. (1998); Turano \& Turano (1998); Costa et al. (1999) e Santos, Jr. (2000, informação verbal), o articulador é um dispositivo mecânico metálico ou quase totalmente metálico utilizado para representar as articulações temporomandibulares e os maxilares, ao qual são fixados os modelos de gesso das arcadas superior e inferior para o diagnóstico e tratamento de pacientes.

\subsubsection{Considerações gerais}

Pruden (1960) atestou que existe a necessidade de se utilizar os modelos de estudo para o diagnóstico e plano de tratamento.

Teteruck \& Lundeen (1966) atestaram que o uso de um articulador está na dependência de uma precisa transferência feita pelo arco facial.

Segundo Hickey et al. (1967), o articulador é um dos principais instrumentos utilizados na Odontologia para o diagnóstico e plano de tratamento. 
Tanaka et al. (1975) comprovaram que o propósito principal do articulador é simular ou reproduzir movimentos selecionados da mandíbula. Também são importantes para o diagnóstico e plano de tratamento. Para os autores, os articuladores semi-ajustáveis são precisos nas posições inicial e terminal dos movimentos mandibulares. Contudo, todos os movimentos intermediários são arbitrários.

Em relação aos tipos de articuladores utilizados pelos cirurgiões-dentistas, Mohamed et al., verificaram num estudo de 1976 nos Estados Unidos, que aproximadamente $64 \%$ eram do tipo charneira ou articuladores simples, $26 \%$ eram semi-ajustáveis e os restantes $10 \%$ eram totalmente ajustáveis. Verificaram ainda que, quando esses profissionais nem sequer mandavam os modelos articulados e não especificavam o tipo de articulador a ser utilizado, em 78,6\% dos casos os técnicos de laboratório escolhiam os simples ou de charneira, os semi-ajustáveis em $17 \%$ dos modelos e de apenas $1,9 \%$ para os totalmente ajustáveis. Os restantes $2,5 \%$ dos modelos não eram montados.

Tanaka \& Finger (1978) fizeram uma investigação com três tipos de articuladores semi-ajustáveis. Esses autores também demonstraram as mesmas aplicações dos articuladores semi-ajustáveis e totalmente ajustáveis.

Para Celenza (1979) os articuladores permitem uma análise oclusal, o enceramento de diagnóstico e auxilia na formulação do plano de tratamento. Quanto à reabilitação oral, eles proporcionam um perfeito funcionamento fisiológico e uma posição que garanta as funções dentro do limite do movimento dinâmico.

Balthazar et al. (1981) citado por Bassanta \& Srna (1996) relataram em seu trabalho que os articuladores foram desenvolvidos para simularem as relações e os movimentos maxilomandibulares. 
O dicionário de termos odontológicos americano, conforme citação encontrada no trabalho de Wise (1982), define articulador como um "aparelho mecânico que representa a articulação temporomandibular, a maxila e a mandíbula, no qual os modelos de gesso são fixados". Se os modelos forem precisamente montados em articulador, é possível simular certas relações oclusais. A facilidade dos articuladores em reproduzir precisamente as relações oclusais depende de sua capacidade de ajuste. Segundo o mesmo autor, surgiram os articuladores anatômicos, assim denominados por serem utilizados para simular o relacionamento funcional existente entre os dentes superiores e inferiores.

Ainda segundo esse autor, os articuladores são usados para:

1) diagnóstico: eles capacitam o profissional a observar as relações oclusais. Além disso, permitem a realização do enceramento de diagnóstico e o reposicionamento dental nos modelos com um certo grau de precisão.

2) restauração dental: os articuladores facilitam o desenvolvimento da oclusão e da estética (dá ao operador um melhor senso de perspectiva, prevenindo a construção de restaurações com planos oclusais incorretos).

No entendimento de Barnett (1984) os articuladores são aparelhos destinados a montagem de modelos de diagnóstico, sendo úteis para a análise oclusal e, também, construção de próteses dentais. Para esse autor, alguns articuladores são capazes de imitar os movimentos mandibulares mais precisamente do que outros, porém todos os articuladores apresentam falhas ao representar os mecanismos funcionais da mandíbula em seu todo. Ainda assim, o articulador é um auxiliar valioso no estudo da oclusão, desde que todo cuidado seja tomado nas técnicas de registro, e seja utilizado de acordo com suas instruções de uso. O autor é pragmático quando afirma que o articulador é um outro meio auxiliar de diagnóstico o qual, quando combinado com o 
histórico, com as radiografias e com o exame clínico do paciente, pode ajudar a produzir um plano de tratamento mais completo.

Carter (1984) foi também muito oportuno ao ensinar que muitos procedimentos diagnósticos deveriam ser repensados à luz de um conhecimento profundo da articulação temporomandibular.

Segundo Smith (1985) a maior diferença entre os articuladores introduzidos de 1970 até 1985 e aqueles desenvolvidos entre 1899 e 1915, é que estes últimos foram direcionados para o uso em próteses totais, enquanto que os articuladores da época de seu trabalho foram preferentemente direcionados para o uso em prótese parcial fixa. Essa diferença originou uma dicotomia entre os tipos de articuladores utilizados em prótese parcial fixa e em prótese parcial removível.

Para Zuckerman (1985) os articuladores são planejados para duplicar o eixo de rotação da mandíbula do paciente. Quando o registro e a montagem são acompanhados de precisão, os modelos permanecerão em relação cêntrica, mesmo que a dimensão vertical seja alterada no articulador. A precisão depende do método utilizado para a montagem, da precisão dos instrumentos utilizados e da habilidade e experiência do profissional no uso desses instrumentos.

Elledge et al. relataram em 1989, que os modelos de diagnóstico fornecem aos profissionais uma perspectiva das necessidades dentais do paciente. Para esses autores, contudo, os modelos devem estar precisamente montados num articulador a fim de permitir o estudo das relações oclusais e, bem assim, a simulação dos movimentos mandibulares.

Wright Jr. (1989) mencionou que os articuladores são utilizados há muitos anos na Odontologia para simular a postura maxilomandibular em posição estática além dos movimentos funcionais e parafuncionais. 
Para Tamaki et al. (1990) a efetividade dos articuladores está subordinada à capacidade de reproduzir os movimentos mandibulares do paciente.

Também estudando a efetividade dos articuladores, Pitchford (1991) enfatizou que o modelo de gesso superior deve estar nesses aparelhos na mesma dimensão vertical que o maxilar superior ocupa em relação ao crânio do paciente.

Para Hayashi et al. (1994) a análise oclusal é um dos mais importantes procedimentos para o diagnóstico da função estomatognática ou para a avaliação de uma prótese dental. E o articulador é o instrumento utilizado para esse fim.

Santos Jr. et al. (1996) asseveraram que a montagem precisa dos modelos de gesso nos articuladores é auxiliada pela reprodução espacial das relações da arcada superior à base do crânio do paciente e o eixo de rotação transversal dos côndilos da mandíbula.

Para Turano \& Turano (1998) o propósito dos articuladores é permitir a realização da análise oclusal e reabilitação oral em prótese dental.

Costa et al. (1999) desenvolveram um método para melhoria do uso desses instrumentos e demonstraram ser possível conseguir-se uma razoável precisão de montagem dos modelos de gesso de arcadas superiores, quando se utiliza uma técnica criteriosa.

\subsubsection{Classificação}

Devido ao grande número de articuladores existentes, com seus mais variados ajustes, a revisão da literatura revelou que muitos tipos de classificações foram propostas, desde que começaram a ser estudados. 
Não existe dentre os objetivos dessa revisão, a pretensão de esgotar o assunto referente a classificação dos articuladores, cuja literatura é vasta. Apenas serão mencionados aqueles autores que mais se destacaram no esclarecimento do desenvolvimento dos articuladores semi-ajustáveis, cujas afirmativas serão utilizadas nesse estudo.

Destacam-se as seguintes citações:

Gillis (1926) citado por Rihani (1980) dividiu os articuladores em adaptáveis ou tipo ajustável e medianos ou tipo fixo.

Boucher (1934) citado por Rihani (1980) classificou os articuladores em não ajustáveis e ajustáveis. Também subdividiu os ajustáveis em instrumento bidimensional e tridimensional.

Beck (1962) citado por Rihani (1980) baseou sua classificação no desenho dos instrumentos. Dividiu-os em 3 categorias: (1) instrumento de suspensão, (2) instrumento de eixo e (3) instrumento trípode.

Weinberg (1963b), adotou uma classificação diferente baseada na concepção associada com cada articulador. Na opinião do autor os articuladores podem ser:

1. arbitrários - são todos aqueles construídos segundo a teoria esférica de Monson de 1918. O eixo de rotação presente nesse tipo de articulador é meramente para abrir e fechar os modelos. Eles não duplicam os movimentos mandibulares do paciente.

2. posicionais ou estáticos - são aqueles construídos segundo o conceito do oclusor trípode de Stansbery de 1929. Nessa categoria o princípio de desenho não inclui o eixo de rotação. Não existe controle condilar. A oclusão cêntrica cria um ponto de início para os movimentos horizontais excêntricos, os quais são governados por mecanismos-guia colocados de maneira tripodal no nível do plano oclusal. Os movimentos realizados por esse articulador efetivamente são os mesmos do tipo 
que possui eixo de rotação, porém por causa da ausência de uma distribuição anatômica e forma das guias, é difícil visualizar e analisar seus componentes básicos.

3. semi-ajustáveis - são aqueles que contam com os ajustes da guia condilar, ângulo de Bennett e guia incisal (concepção do Hanau H, Gysi Trubyte, Whip Mix, Gnatus, Bio Art e Dent-Flex).

4. totalmente ajustáveis - são aqueles que dispõem das regulagens das guias condilares, ângulo de Bennett, guia incisal, ângulo de Fischer e distância intercondilar individualizada (concepção do Hanau Kinoscope; McCollum Gnathoscope, Stuart, Di Pietro, Denar D4-A e TT II).

Além de Weinberg (1963b); Rihani (1980); Zuckerman (1985) e Todescan et al. (1998) afirmaram existir uma grande variedade de articuladores disponíveis para o uso na Odontologia e são classificados segundo sua capacidade de ajuste. Vão desde simples e arbitrários oclusores ou verticuladores e charneiras, capazes de registrar apenas uma posição oclusal estática (são classificados de não ajustáveis), os semiajustáveis que reproduzem os pontos inicial e final dos movimentos mandibulares, até os articuladores totalmente ajustáveis, capazes de reproduzir todos os movimentos mandibulares.

Posselt (1968) classificou os articuladores de curso simples, de valor médio e os ajustáveis.

Thomas (1973) tentou simplificar as classificações dos articuladores e os dividiu baseando-se no tipo de registro utilizado: (1) arbitrário (não ajustável), (2) posicional (com e sem eixo de registro estático) e, (3) funcionais (com e sem eixo de registro funcional). 
Sharry (1974) classificou os articuladores em simples, tipo dobradiça, tipo guia fixa e os ajustáveis.

Heartwell \& Rahn (1974) enfatizaram o papel dos pantógrafos nos registros da articulação temporomandibular e dividiram os articuladores em 2 classes: (1) instrumentos que irão receber e reproduzir pantografia e traçados gráficos e (2) instrumentos que não irão receber pantografia, os quais são subdivididos em 4 tipos: (a) tipo dobradiça, (b) arbitrários, (c) ajustáveis e, (d) instrumentos desenhados e usados para a construção de próteses totais.

De acordo com os estudos de Henderson \& Steffel (1979); Wise (1982); Shillingburg et al. (1983) e Mohl et al. (1991) os articuladores semi-ajustáveis também podem ser classificados em arcon e não arcon. O termo arcon é uma derivação, preconizada por Bergström (1950) das palavras articulação e côndilo. Nos do tipo arcon, os elementos condilares (postes condilares) estão presentes no ramo inferior do instrumento, assim como os côndilos estão unidos à mandíbula. A guia condilar está unida ao ramo superior do articulador, simulando a própria cavidade articular (Figura 2.4).

A Academia de Prótese Dentária Americana apresentou em 1982 uma classificação semelhante a de Weinberg, 1963b, com quatro categorias: (1) articuladores arbitrários; (2) articuladores posicionais ou estáticos; (3) articuladores semi-ajustáveis e, (4) articuladores totalmente ajustáveis.

Para Wise (1982) existem inúmeros aparelhos que são classificados como articuladores, mas de fato não passam de simples seguradores de modelos, que não simulam os movimentos mandibulares. Para o autor, os modelos podem ser analisados das seguintes formas: (1) articulados na mão; (2) em articuladores simples de planos 
lineares; (3) em articuladores semi-ajustáveis e, (4) em articuladores totalmente ajustáveis.

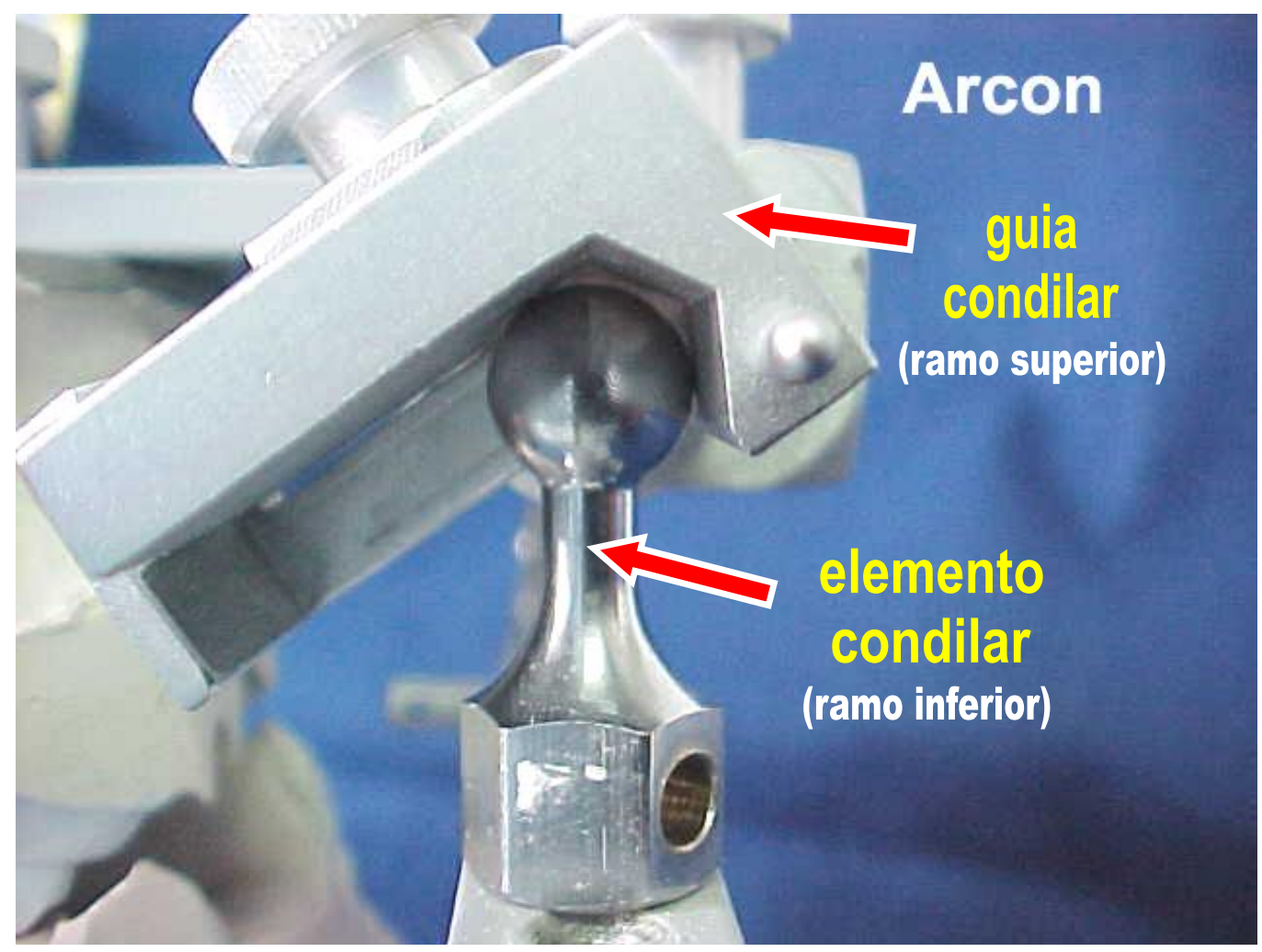

Figura 2.4 - Articulador do tipo arcon, onde os elementos mecânicos da articulação imitam a anatomia humana

Segundo os autores citados, como exemplo de articuladores do tipo arcon podem-se citar: semi-ajustáveis - Dent-Flex, Gnatus e Bio Art, nacionais e o Whip Mix 8500, Denar Mark II, americanos; totalmente ajustáveis - TT II, nacional e o de Stuart e Denar D4 - A, americanos.

Ainda de acordo com esses mesmos autores, nos articuladores do tipo nãoarcon, as guias condilares estão unidas ao ramo inferior e os elementos condilares 
(postes condilares) ao ramo superior do articulador. Como exemplo podem-se citar os articuladores Dentatus (Figura 2.5) e o Hanau modelo H.

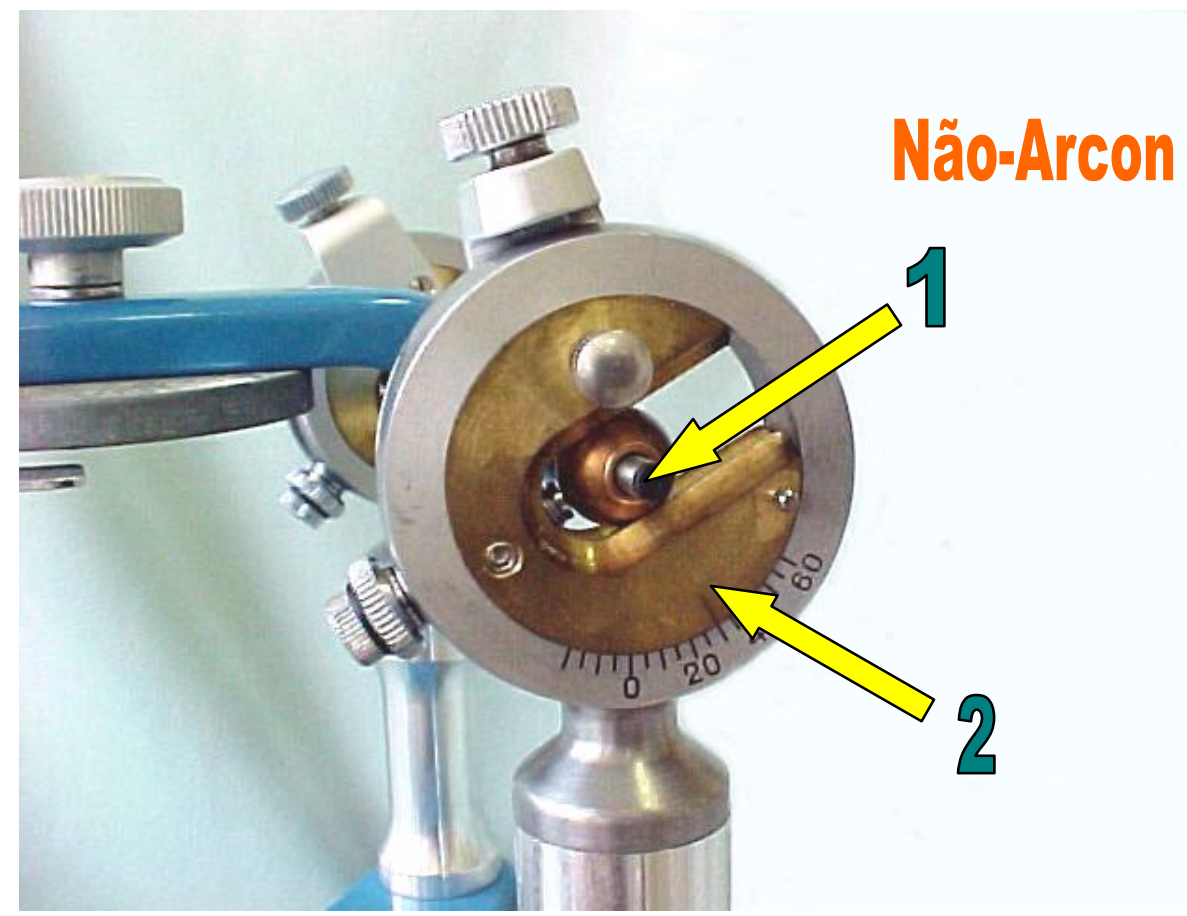

Figura 2.5 - Articulador do tipo não-arcon: (1) elemento condilar no ramo superior e (2) guia condilar no ramo inferior

Para tornar a classificação dos articuladores mais simples na visualização e para evitar confusão por causa de seus sofisticados ajustes, optou-se pela classificação de Rihani (1980) que adotou um sistema baseado no número de registros usados e dos ajustes necessários para o instrumento aceitar esses registros. Esse autor classificou os articuladores, quanto ao grau de precisão, em três categorias:(1) simples ou não ajustáveis - podem aceitar um ou dois dos seguintes registros: arco facial, relação cêntrica ou protrusão. São articuladores que só reproduzem movimentos de dobradiça (abrir e fechar). Cada articulador é exemplificado com o nome de seu idealizador e a 
data de desenvolvimento: Gariot, 1805; Evans, 1840; Bonwill, 1858; Walker, 1896; Snow, 1906; Gysi Simplex, 1912 (Figura 2.6); Monson, 1918; Stansbery, 1929 e Pankey-Mann, 1955.

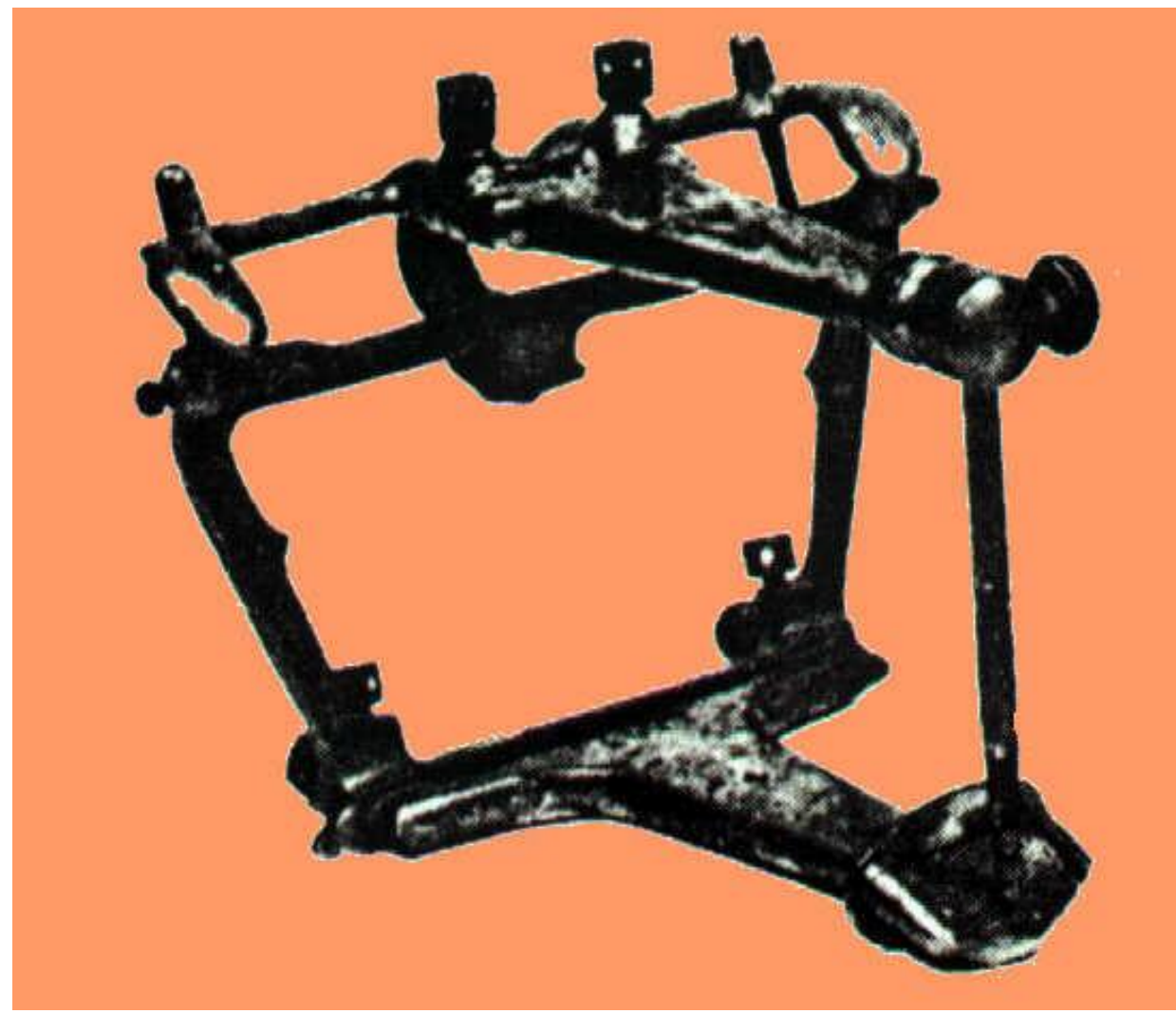

Figura 2.6 - Articulador Gysi Simplex concebido por Alfred Gysi em 1912 (extraído do artigo de Huggett \& Harrison, 1977)

(2) semi-ajustáveis - foram concebidos para aceitar três registros: arco-facial, relação cêntrica e movimento de protrusão. Alguns reproduzem os pontos inicial e final dos movimentos condilares, e a trajetória entre esses dois pontos é retilínea, quando na verdade deveria ser curvilínea. As distâncias intercondilares não são totalmente ajustáveis, e sim representadas em três tamanhos arbitrários (pequeno, médio e 
grande). São exemplos: Snow Acme, 1910; Hanau H, 1921; Gysi Trubyte, 1926; Dentatus, 1944 (Figura 2.7); Whip Mix 8500, 1963.

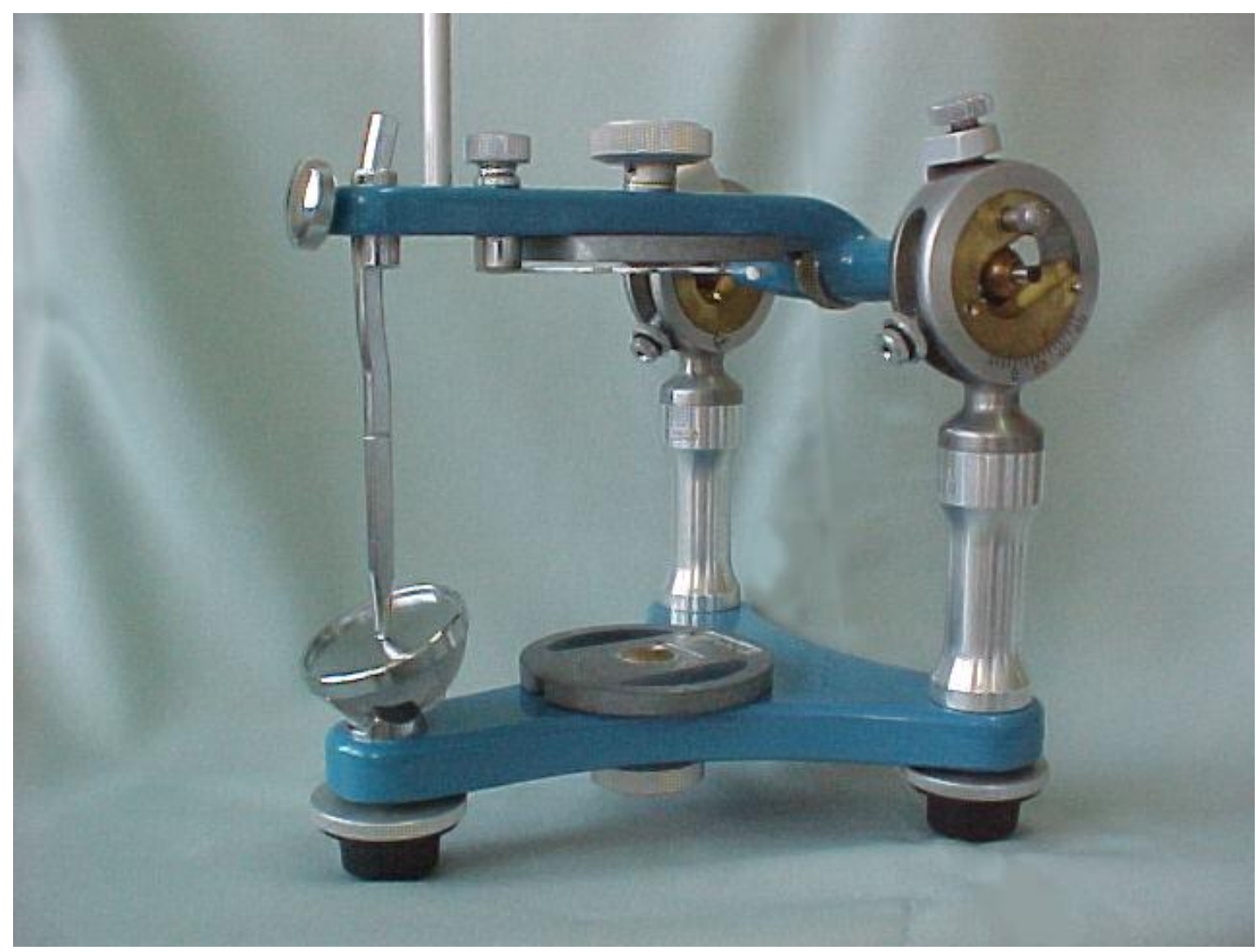

Figura 2.7 - Articulador Dentatus idealizado por Beyron em 1944 na Suécia

(3) totalmente ajustáveis - foram construídos para aceitar cinco ajustes: registro do arco facial, registro da relação cêntrica, registro do movimento protrusivo, registro dos movimentos laterais e registro da distância interproximal individualizada. São exemplos: Hanau Kinoscope, 1923; McCollum Gnathoscope, 1935; Stuart, 1955 (Figura 2.8); Denar D4-A, 1968. 


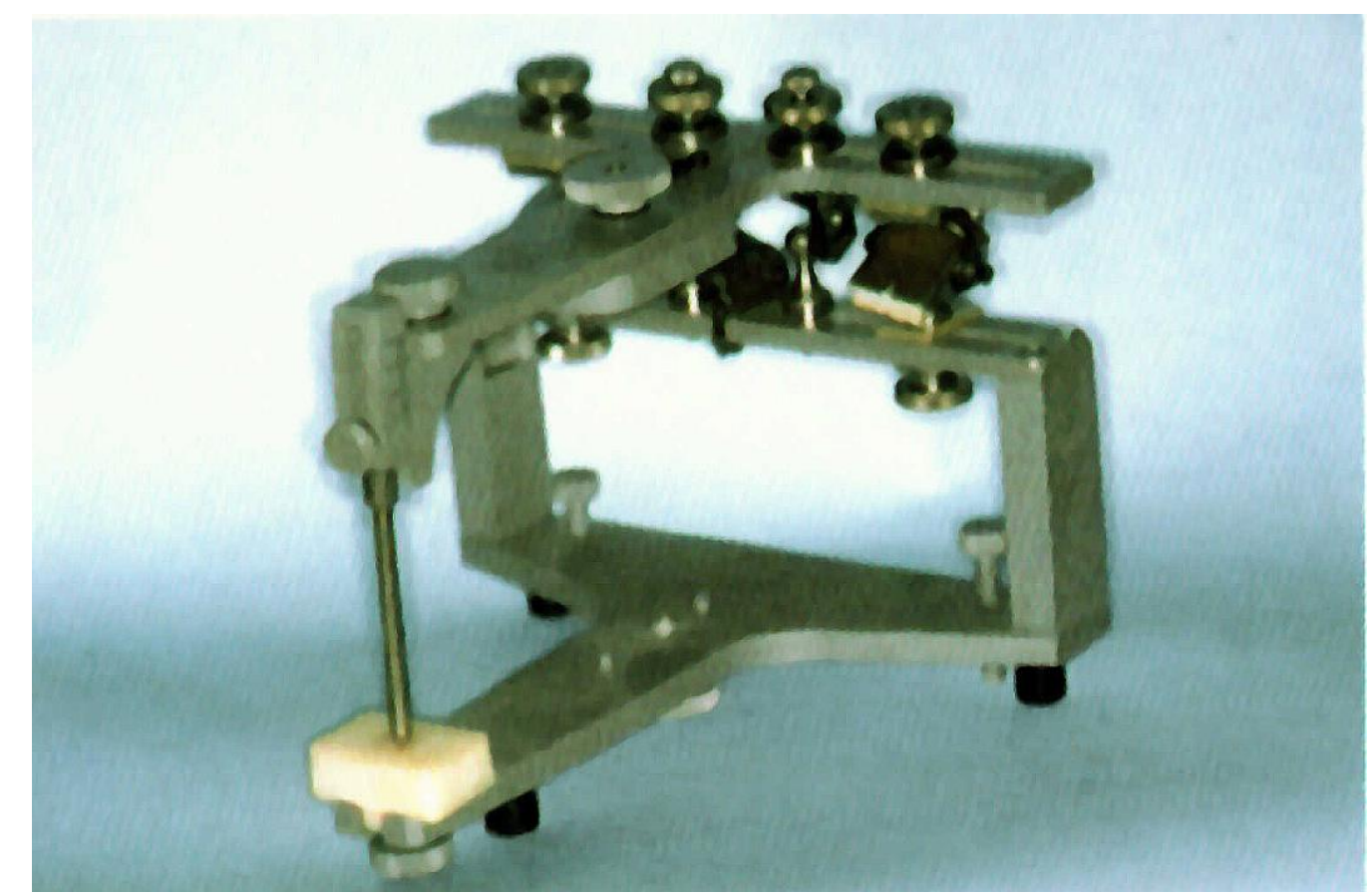

Figura 2.8 - Charles Stuart idealizou em 1955 sua concepção de articulador totalmente ajustável (extraído do livro de Todescan et al., 1998)

\subsubsection{Articuladores simples ou não ajustáveis}

Para Barnett (1984) esses são essencialmente mecanismos de eixo simples do tipo abre e fecha (charneira).

Segundo Whitbeck \& Ivanhoe (1985) esses instrumentos permitem que os modelos sejam movimentados apenas verticalmente. São ideais para a estabilização da oclusão pela técnica do eixo funcional, na qual o modelo oponente é relacionado por meio de uma superfície registrada de todos os movimentos funcionais.

Mohl et al., mencionaram em 1991, que comumente esses articuladores também possuem uma parada vertical ajustável, para impedir danos aos modelos e alterações bruscas na dimensão vertical de oclusão. 
Para esses autores, as limitações físicas desse dispositivo excluem seu uso nos procedimentos diagnósticos ou restauradores mais complicados. Por exemplo, se os modelos montados em charneira produzirem uma trajetória de fechamento diferente daquela do paciente, pode ocorrer travamento de vertentes das cúspides nas restaurações colocadas na boca do paciente.

Outra desvantagem inerente é que os movimentos laterais não podem ser examinados nesses dispositivos.

Ainda de acordo com os autores, os articuladores semi-ajustáveis não permitem movimentos excêntricos (lateralidade e protrusão).

Para Todescan et al. (1998) os articuladores simples são instrumentos pequenos que só reproduzem movimentos de dobradiça, ou seja, abrir e fechar (charneira), permitindo que os modelos sejam movimentados verticalmente em arco, onde o centro de rotação é o eixo da charneira (Figura 2.9).

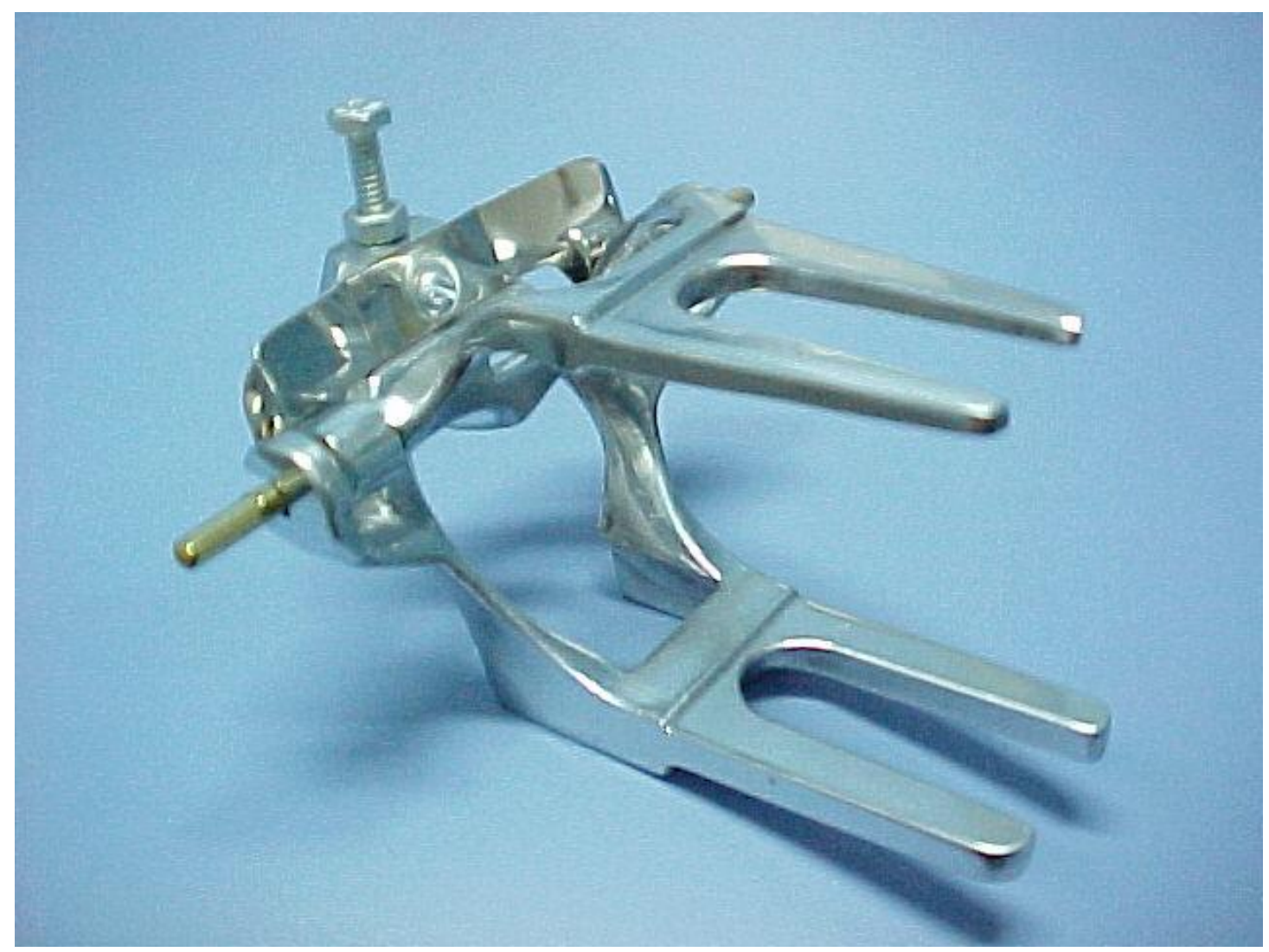

Figura 2.9 - Articulador do tipo charneira (abre e fecha) 


\subsubsection{Articuladores semi-ajustáveis}

Segundo Hickey et al. (1967); Shillingburg et al. (1983); Whitbeck \& Ivanhoe (1985); Desplats (1986); Johnson \& Stratton (1988); Mohl et al. (1991) e Todescan et al. (1998) a maior falha desses articuladores refere-se a não reprodução fiel de todos os movimentos mandibulares, pois, por possuírem as guias condilares planas, que representam as cavidades articulares, reproduzem um percurso reto, quando os contornos anatômicos são curvilíneos.

Além disso, disseram esses autores, o movimento de Bennett é reproduzido nesses articuladores como uma linha de desvio gradual, apesar de que as investigações demonstrem com muita freqüência, que existe nesse movimento um considerável componente de desvio lateral imediato da cabeça do côndilo (Aull, 1965; Hickey et al., 1967).

Para Hickey et al. (1967); Malone \& Koth (1991) e Mohl et al. (1991) mesmo apresentando essas limitações mecânicas em relação a reprodução dos movimentos mandibulares, pela sua simplicidade de manuseio, quando usado adequadamente e o profissional conhece essas limitações, o articulador semi-ajustável pode dar informações valiosas para auxiliar no diagnóstico e nas reconstruções oclusais e, por isso, é largamente utilizado no ensino de Odontologia e na clínica odontológica.

Hickey et al., 1967, publicaram um trabalho detalhando o funcionamento do articulador Whip Mix 8500, o qual é uma simplificação do articulador totalmente ajustável de Stuart e precursor das diversas marcas comerciais de articuladores encontradas em nosso mercado (Figura 2.10). 


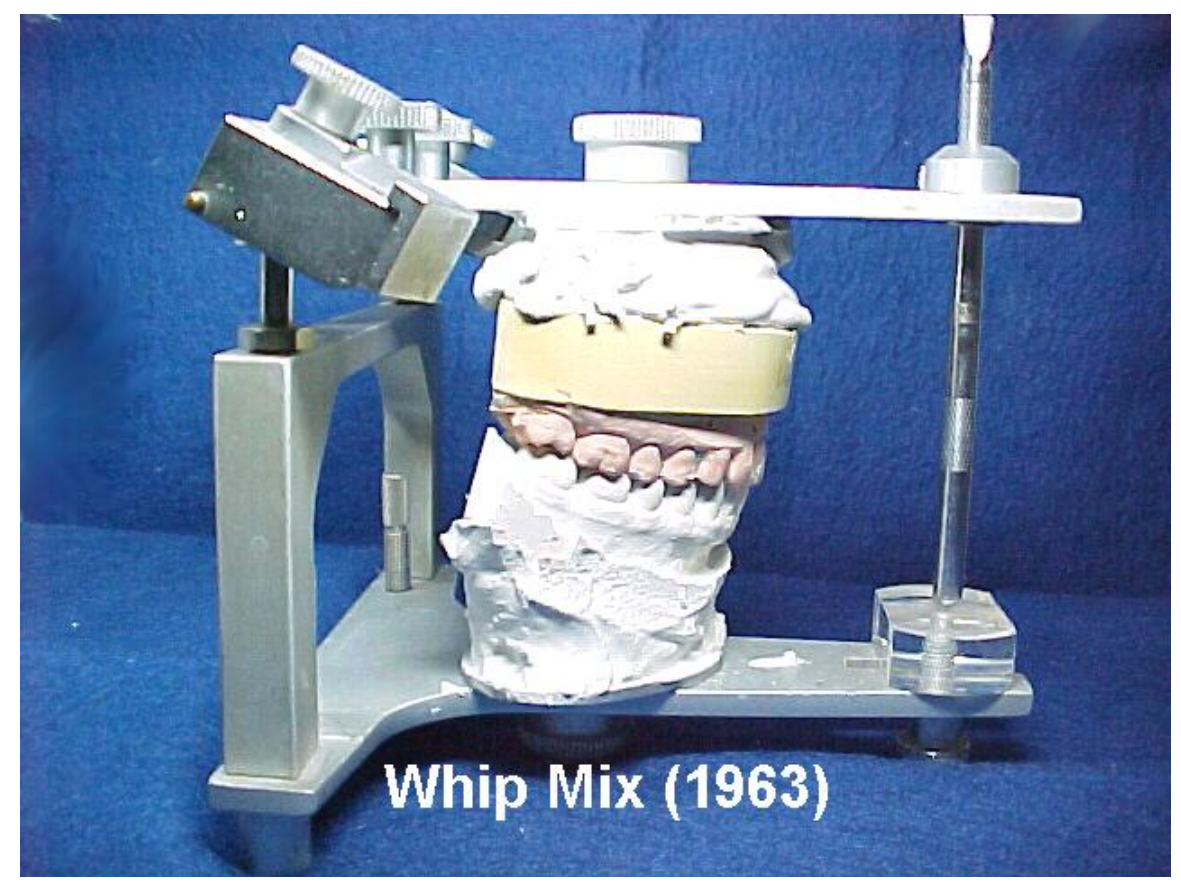

Figura 2.10 - Articulador arcon semi-ajustável Whip Mix 8500

Para Bellanti (1973) os articuladores semi-ajustáveis orientam somente o componente lateral do movimento de rotação condilar. Além disso, são capazes de reproduzir a largura intercondilar pequena e média com uma margem de erro não significativa. Porém o ajuste da largura maior parece não permitir adequadamente o alcance possível da variação anatômica do paciente que foi descrita por Aull (1965).

Segundo o autor, o erro incorporado numa largura extrema iria requerer mais do que um ajuste mínimo intra-oral da prótese em movimentos excêntricos. Ainda segundo o autor, os articuladores semi-ajustáveis são capazes de somente reproduzir movimentos simples laterais e são incapazes de reproduzir qualquer variação durante os movimentos protrusivos.

Hobo et al. (1976) mostraram que na ausência de perda de dimensão vertical e problemas oclusais severos, é plenamente possível a utilização de articuladores semiajustáveis. 
Mohamed et al. (1976) referiram que os articuladores semi-ajustáveis são tradicionalmente utilizados em prótese dental. São importantes para o ensino e aplicação clínica dos princípios de oclusão e conscientizam os estudantes a respeito da importância desse instrumento como um auxiliar para elaborar um diagnóstico e tratamento da oclusão dos pacientes.

No entender de Whitsett et al. (1977) os articuladores semi-ajustáveis podem ser utilizados na maioria dos pacientes com múltiplas restaurações ou próteses parciais fixas, onde não exista perda de dimensão vertical e com um mínimo de evidência de problemas oclusais.

Tanaka \& Finger (1978) descreveram o articulador Whip Mix como sendo do tipo arcon. São construídos com a capacidade de ajustes na distância intercondilar, a qual é semi-ajustável no movimento lateral. Pode ser ajustado em pequeno, médio ou grande, dependendo do registro obtido do paciente. Dentro das guias condilares possuem uma guia condilar horizontal e um ajuste progressivo do desvio lateral imediato.

Rihani (1980) mencionou em seu trabalho que esses articuladores são capazes de aceitar pelo menos o uso do arco facial para montar o modelo superior na relação apropriada com seu eixo de rotação condilar e, também segundo Mohl et al. (1991), a relação cêntrica e os registros interoclusais protrusivos. Em certos casos essas variáveis são freqüentemente deixadas em posições padrão que representam a média da morfologia no adulto e os registros de mordidas interoclusais não são consignados especificamente. Esse último método obviamente é menos preciso do que os registros reais feitos num determinado paciente. Mas os registros individuais podem estar associados a erros relativamente grandes. 
Para o autor, em certos centros de estudos, por esse motivo, as vantagens dos registros individuais são questionadas e as angulações médias são utilizadas (mesmo quando são empregados os articuladores semi-ajustáveis).

Gibbs \& Lundeen (1982); Drago \& Rugh (1982) e Mongini (1982) demostraram em seus estudos a importância dos articuladores semi-ajustáveis do tipo arcon na reabilitação por meio de prótese dental.

Kafandaris \& Theodorou (1982) relataram que o articulador Whip Mix é utilizado pelas escolas de Odontologia da Grécia como um importante adjunto no ensino da oclusão, principalmente pela sua facilidade de uso e baixo custo.

Segundo Wise (1982) e Mohl et al. (1991) nos articuladores semi-ajustáveis as inclinações condilares são ajustadas utilizando-se, por exemplo, placas de cera chamadas de registro ou placas de mordida, mediante as quais se transfere a posição terminal dos côndilos da mandíbula ao instrumento. Essas placas têm em média de 3 a $5 \mathrm{~mm}$ de espessura, de modo que os dentes dos modelos de gesso superior e inferior ficam separados por essa distância, enquanto forem ajustadas as inclinações condilares. Quando se retiram esses registros, de um articulador tipo arcon e os dentes são ocluídos, as inclinações condilares permanecem as mesmas. Entretanto, quando os dentes são ocluídos num articulador não arcon, ocorre uma alteração no ângulo entre a inclinação da trajetória condilar e o plano oclusal dos dentes da maxila, com o articulador aberto (onde as inclinações do articulador são ajustadas, devido a espessura da placa de mordida) e fechado (como é utilizado).

Por essas características, ainda segundo os autores, os articuladores arcon tem tido seu uso difundido devido a sua precisão e facilidade de manipulação para o enceramento oclusal necessário nas restaurações dentais. Porém a posição cêntrica é menos facilmente mantida quando a oclusão de todos os dentes posteriores está sendo 
manipulada. Essas características tornaram-no impopular para a montagem de dentes em próteses totais. Em vista disso, o articulador não arcon tem se mostrado mais popular para a confecção de próteses totais. Os articuladores arcon, equipados com dispositivos firmes de fixação cêntrica que impedem o deslocamento posterior, contornam a maioria das objeções.

De acordo com Shillingburg et al. (1983) são instrumentos que reproduzem os pontos inicial e final de alguns dos movimentos condilares, sendo que a trajetória entre esses dois pontos é representada por uma linha reta, quando na verdade deveria ser uma trajetória curvilínea. Não reproduz as trajetórias intermediárias.

Esses mesmos autores também mencionam que a distância intercondilar desses instrumentos não é totalmente ajustável. Pode ser ajustada, quando muito, a valores pequenos, médios e grandes ou com valores relativos de 1, 2 e 3 . As restaurações feitas com esse tipo de articulador necessitarão de algum ajuste na boca, porém esse procedimento será de pouca importância se a restauração for confeccionada cuidadosamente, sendo possível utilizá-lo na maioria das reconstruções unitárias e próteses parciais fixas.

Barnett (1984) postulou que os articuladores semi-ajustáveis podem ser ajustados em relação a inclinação da trajetória condilar, da guia incisal e aos movimentos simulados de Bennett (reproduz o desvio lateral imediato como uma linha reta).

Numa pesquisa realizada por Gross \& Gazit em 59 faculdades de Odontologia norte-americanas em 1984, publicada por esses autores em 1985 e, outra realizada por Smith (1985), também em 59 faculdades de Odontologia norte-americanas, foi constatado que o articulador Whip Mix 8500 é o mais freqüentemente utilizado, sendo inclusive sugerido para o uso na construção de próteses parciais fixas e removíveis. 
Dos 81 tipos de articuladores utilizados no ensino de Odontologia daquele país, 62 (76,5\%) são do tipo arcon, por permitirem a separação dos ramos superior e inferior.

Whitbeck \& Ivanhoe (1985) verificaram que os articuladores semi-ajustáveis são limitados aos registros que são feitos para analisar várias posições da mandíbula, porém os movimentos mandibulares entre essas posições não são registrados.

Gross et al. (1990) também verificaram em seus trabalhos que os articuladores semi-ajustáveis são os mais utilizados no ensino da Odontologia em muitos países, sendo que o Whip Mix 8500 encontra-se entre os modelos mais usados.

Embora esses articuladores tenham a maior preferência entre os profissionais, os não arcon demonstraram em vários estudos terem um melhor nível de reprodutibilidade na utilização de registros interoclusais. Esses pesquisadores mostraram em seus estudos que os articuladores semi-ajustáveis usando um registro interoclusal tem um nível baixo de reprodutibilidade e estão sujeitos a variações do instrumento, operador e registros oclusais.

Num estudo comparativo da habilidade dos articuladores em reproduzir os movimentos mandibulares, realizado por esses autores, usando um articulador eletrônico Cyberhoby (Nippon Avionics, Tokyo, Japan), entre 6 articuladores semiajustáveis arcon e não arcon, foi verificado um maior ângulo entre os arcon em relação ao ângulo formado entre o ramo superior e o plano oclusal, quando comparados ao ângulo formado entre o plano de Frankfurt e o plano oclusal do paciente.

O estudo desses autores confirmou pesquisas anteriores, que também demonstraram que os articuladores semi-ajustáveis do tipo arcon, que utilizam registros interoclusais, possuem um nível baixo de reprodutibilidade e estão sujeitos a variações dos instrumentos, do operador e dos registros oclusais. 
Zanetti \& Ribas $(1996,1997)$ estudaram um novo método para simplificação e maior precisão de montagem de modelos de arcadas superiores em articuladores semiajustáveis, e demonstraram uma maior vantagem do método de transferência direta do molde para o articulador.

Todescan et al. (1998) demonstraram a utilização dos articuladores semiajustáveis em casos de reabilitações orais.

Costa (1998) e Costa et al. (1999) apontaram uma melhoria na precisão de montagem de modelos de gesso de arcadas superiores em articuladores semiajustáveis e desenvolveram um dispositivo que é acoplado ao arco facial que proporciona uma estabilidade no posicionamento do modelo superior em relação ao eixo transversal de rotação da mandíbula.

\subsubsection{Articuladores totalmente ajustáveis}

Bonfante et al. (1974) realizaram um estudo comparativo dos registros do eixo terminal de rotação pela técnica arbitrária e cinemática e demonstraram que o uso desses complexos instrumentos não são necessários para a montagem com o eixo de rotação do paciente.

Segundo Rihani (1980) os articuladores totalmente ajustáveis são instrumentos capazes de registrar os ajustes obtidos pelo arco facial, a relação cêntrica, o registro protrusivo e a distância intercondilar.

No entendimento de Wise (1982); Ramfjord \& Ash (1983); Shillingburg et al.

e Mohl et al. (1991) esses instrumentos mais complicados e inquestionavelmente mais precisos, contudo, não são necessários no tratamento de 
todos os pacientes, mas estão reservados aos casos mais complexos e à pesquisa e, possivelmente, para uso em paciente com uma capacidade de adaptação precária para um desajuste mínimo no sistema mastigador.

De acordo com esses autores, para usar um articulador totalmente ajustável, é necessário um treinamento especial, exigindo um alto grau de habilidade e mais tempo para ser executada a técnica, além de uma quantia considerável (Figura 2.11).

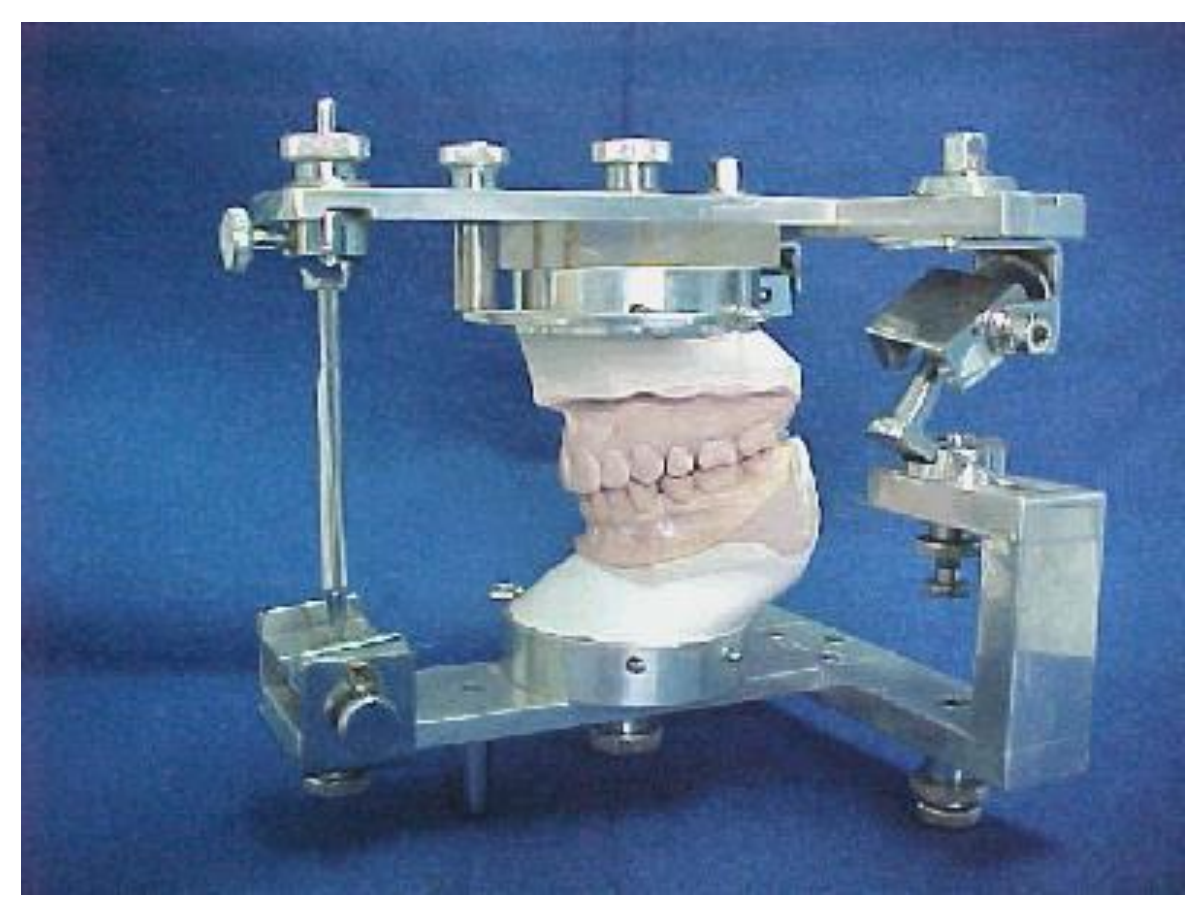

Figura 2.11 - Articulador totalmente ajustável concebido por Tadachi Tamaki

Para Shillingburg et al. (1983) e Todescan et al. (1998) esses instrumentos são planejados para reproduzir todas as características dos movimentos excêntricos, inclusive o desvio lateral imediato, o progressivo (ou gradual) e a inclinação e curvatura da trajetória condilar. A distância intercondilar é totalmente ajustável. Quando o eixo terminal de rotação é localizado cinematicamente e são obtidos 
registros precisos dos movimentos mandibulares, estes podem ser parcialmente reproduzíveis.

Whitbeck \& Ivanhoe (1985) mostraram que os articuladores totalmente ajustáveis possuem ajustes variáveis para os movimentos multidirecionais e bordejantes irregulares. Eles são programados por meio de traçados pantográficos. Podem ser utilizados com qualquer teoria ou esquema oclusal, incluindo as oclusões balanceadas, de função de grupo ou mutuamente protegida. A morfologia oclusal pode ser concebida para permitir que as cúspides, fóssulas e sulcos funcionem eficientemente e harmoniosamente com os movimentos mandibulares. Com esse aparelho, tem-se a oportunidade de criar a oclusão fisiológica desejada para as mais complexas restaurações, envolvendo uma ou as duas arcadas, com um mínimo de ajustes intra-orais.

\subsection{Arco Facial}

Em 1880, Hayes citado por Heartwell \& Rahn (1974) usou um instrumento em formato de pinça que ele chamou de "caliper" (compasso, em inglês). Esse dispositivo não foi usado como um arco facial como é usado hoje, mas ele relatou o ponto incisivo médio à distância dos côndilos mandibulares.

Por volta da virada do século 19, Gysi (s.d.) citado por Heartwell \& Rahn (1974) desenvolveu um dispositivo similar a um arco facial principalmente para registrar a trajetória dos côndilos da mandíbula. Em 1899, Snow citado por Heartwell \& Rahn (1974) desenvolveu e patenteou o arco facial como é conhecido hoje (Figura 
2.12). Os arcos faciais utilizados na atualidade baseiam-se nas modificações do arco de Snow.

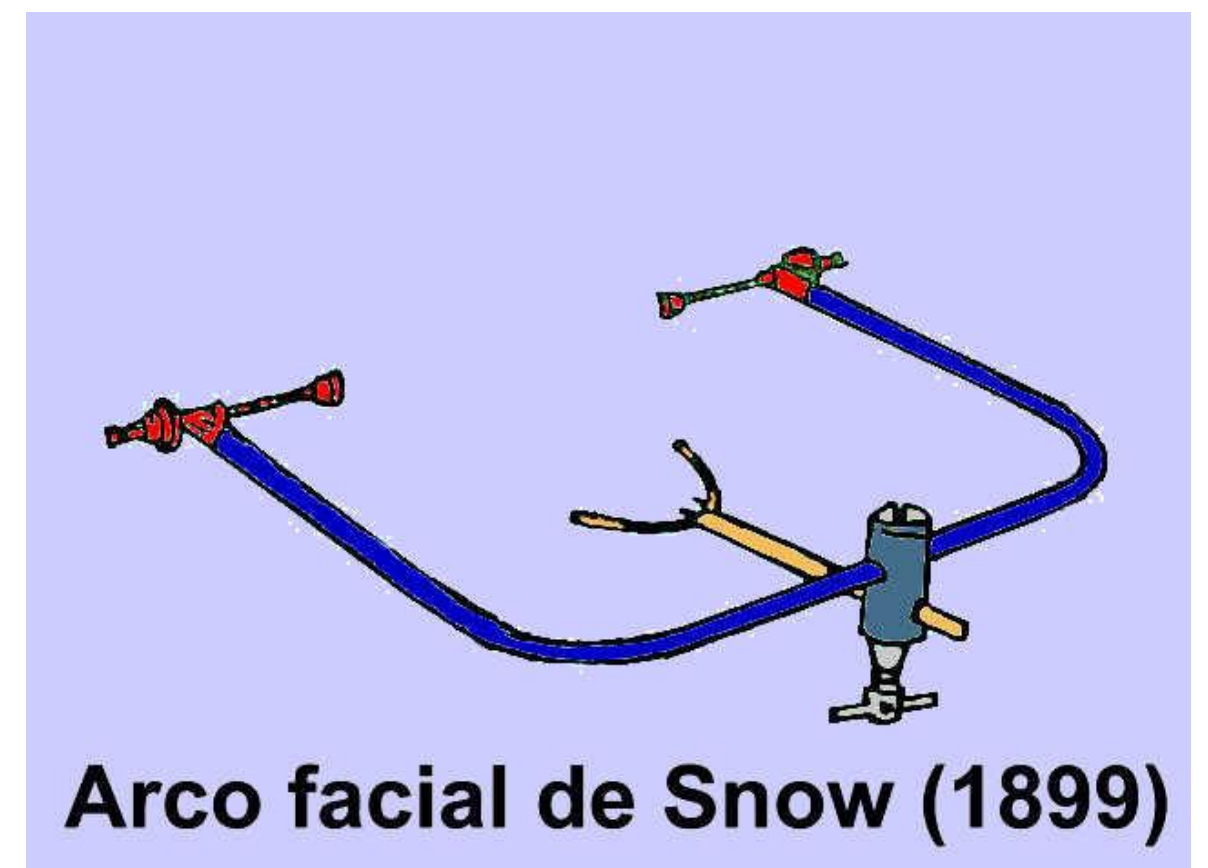

Figura 2.12 - 0 arco facial arbitrário simples foi idealizado e patenteado por Snow e é essencialmente o mesmo utilizado hoje em dia (extraído do livro de Turano \& Turano, 1998)

\subsubsection{Definição}

Pruden (1960) definiu o arco facial como sendo um dispositivo que orienta o modelo superior no articulador.

Heartwell \& Rahn (1974) definiram o arco facial como sendo um dispositivo utilizado para duplicar as distâncias dos centros rotacionais condilares mandibulares no articulador.

Para Whitsett et al. (1977) o arco facial é um dispositivo que reproduz, num aparelho mecânico, a mesma relação entre os dentes do modelo de gesso e o eixo 
rotacional do articulador como o existente entre os dentes na boca e o eixo de rotação dos côndilos da mandíbula.

Henderson \& Steffel (1979) definiram o arco facial como sendo um dispositivo relativamente simples utilizado para obter-se o registro de transferência com a finalidade de orientar o modelo maxilar superior no instrumento de articulação.

Kotwal (1979) conceituou o arco facial como sendo um dispositivo semelhante a um compasso que é utilizado para registrar o relacionamento da maxila com a articulação temporomandibular e aos ossos do crânio. Para esse autor, a história do arco facial se iniciou com Bonwill em 1860, Balkwill em 1866 e com Hayes em 1880, o qual construiu um mecanismo denominado de compasso curvo.

Para Hockel (1980) o arco facial é um compasso que usa três pontos de referência para estabelecer um plano horizontal na cabeça do paciente. A maxila e os dentes superiores estão relacionadas a esse plano.

Tamaki, 1981, esclareceu que o arco facial é um dispositivo destinado a orientar a transferência dos modelos para o articulador. Por meio dele consegue-se montar os modelos respeitando as características individuais de posição, inclinação e o grau de assimetria de uma arcada dental em relação aos côndilos da mandíbula.

Para Palik et al. (1985) o arco facial é um dispositivo utilizado no desenvolvimento dos registros intermaxilares, relacionando o modelo maxilar superior aos elementos condilares mecânicos no articulador da mesma maneira que a maxila do paciente está relacionada ao eixo terminal de rotação dos côndilos da mandíbula.

Segundo Mohl et al. (1991) e Todescan et al. (1998) o arco facial é o dispositivo, utilizado com os articuladores, que relaciona o modelo de gesso da arcada superior de acordo com o relacionamento espacial da maxila à base do crânio do 
paciente. Portanto, tem este a função de transferir as características individuais da arcada dental do paciente para o articulador. Essa relação é importante ao se alterar a dimensão vertical de oclusão durante a confecção de próteses dentais.

Akerly (1996) demonstrou que o arco facial é um dispositivo que fornece importantes dados para programação do articulador, visando simular os movimentos mandibulares do paciente ao redor do eixo transversal de rotação de seus côndilos.

Turano \& Turano (1998) referiram-se ao arco facial como sendo um dispositivo que capta os registros do posicionamento da arcada dentária superior do paciente e transfere essas informações para o articulador.

Para Todescan et al. (1998) o arco facial é um dispositivo complementar, que tem por função a transferência das características individuais da arcada dentária superior do paciente para o articulador.

\subsubsection{Considerações gerais}

Weinberg (1961) avaliou a montagem com arco facial e demonstrou tratar-se de um importante passo na construção de restaurações que requeiram um mínimo de ajuste intra-oral. Ele também mostrou o alto grau de precisão dos arcos faciais arbitrários em pacientes para prótese total.

Para Weinberg (1963a) a utilização apropriada de um articulador anatômico está na dependência do uso de um preciso arco facial.

Weinberg (1963a); Whitsett et al. (1977); Shillingburg et al. (1983) e Zuckerman (1982, 1985), demonstraram em seus estudos que se os modelos forem montados de tal forma que o articulador feche ao redor de um eixo diferente daquele 
dos côndilos da mandíbula do paciente, os dentes ocluirão no articulador em posição diferente do que na boca do paciente.

Parel (1972) demonstrou que quando existir necessidade de alterações na dimensão vertical de oclusão, seria necessário o uso de um arco facial para obter-se resultados mais eficientes e precisos.

Para Jones (1974) os procedimentos necessários destinados a utilização do arco facial são orientações difíceis de ensinar, tendo em vista que para se proceder à uma transferência exata das informações posicionais da maxila do paciente são necessários conhecimentos teóricos e práticos, não somente a respeito do manuseio do dispositivo, mas também, controle do paciente. Daí a necessidade do aprendizado começar num crânio seco ou manequim odontológico e, num segundo estágio, iniciar treinamento prático com os colegas de turma e, somente depois, utilizá-lo no paciente.

Whitsett et al. (1977) afirmaram que o uso dos arcos faciais arbitrários adaptados ao meato acústico externo tem adquirido uma ampla aceitação e tem sido largamente utilizados. Afirmaram ainda que o primeiro passo para o uso de um arco facial é determinar a localização do eixo de rotação horizontal dos côndilos da mandíbula. Quanto mais exata for essa localização, mais precisa será a transferência e subseqüente montagem dos modelos maxilares no articulador.

Laing \& Wise (1978) demostraram que o uso do arco facial da Whip Mix produz uma localização do eixo de rotação da mandíbula próxima àquela obtida pelo arco cinemático e, por isso, pode ser usado como uma técnica aceitável.

Loos (1978) relatou em seu trabalho que o arco facial é utilizado para montar o modelo maxilar superior na mesma posição relativa ao eixo de abertura do articulador, da mesma maneira que a arcada superior do paciente é posicionada em relação ao eixo terminal de abertura dos côndilos da mandíbula. 
Thorp et al. (1978) revelaram que o arco facial do articulador Whip Mix não apresentou diferenças significativas de montagem de modelos, quando comparado com o articulador Hanau.

Kotwal (1979) relatou que o arco facial permite maior precisão do arco de fechamento no articulador quando os registros interoclusais em cera são removidos e os dentes no articulador são ocluídos.

Para Henderson \& Steffel (1979); Zuckerman (1985); Pitchford (1991) e Ellis III et al. (1992) quando o registro e a montagem são acompanhados de precisão, os modelos montados permanecerão na posição de relação cêntrica mesmo se a dimensão vertical for alterada no articulador. É de suma importância que o ângulo formado entre o plano oclusal e o plano de Frankfurt no paciente seja o mesmo que o formado pelo plano oclusal do modelo de gesso superior em relação ao ramo superior do articulador. A idéia de que o pórion (ponto central da margem superior do meato acústico externo) e a borda inferior da cavidade orbital formam um plano paralelo ao plano de referência horizontal foi originalmente adotada num congresso de antropologia em Frankfurt, Alemanha, em 1822, tornando-se conhecido como plano de Frankfurt (Figura 2.13).

Para Hockel (1980) que é professor do curso de Procedimentos de Reconstrução Gnatológica da Universidade da Califórnia, os gnatologistas acham que o uso do arco facial é essencial para planejar, registrar, avaliar, verificar e corrigir seus empenhos ortopédicos. Para esse autor o arco facial é um compasso curvo que utiliza três pontos de referência para estabelecer o plano horizontal na cabeça do paciente. Segundo o autor, a arcada superior e os dentes superiores estão relacionados ao plano horizontal estabelecido. 


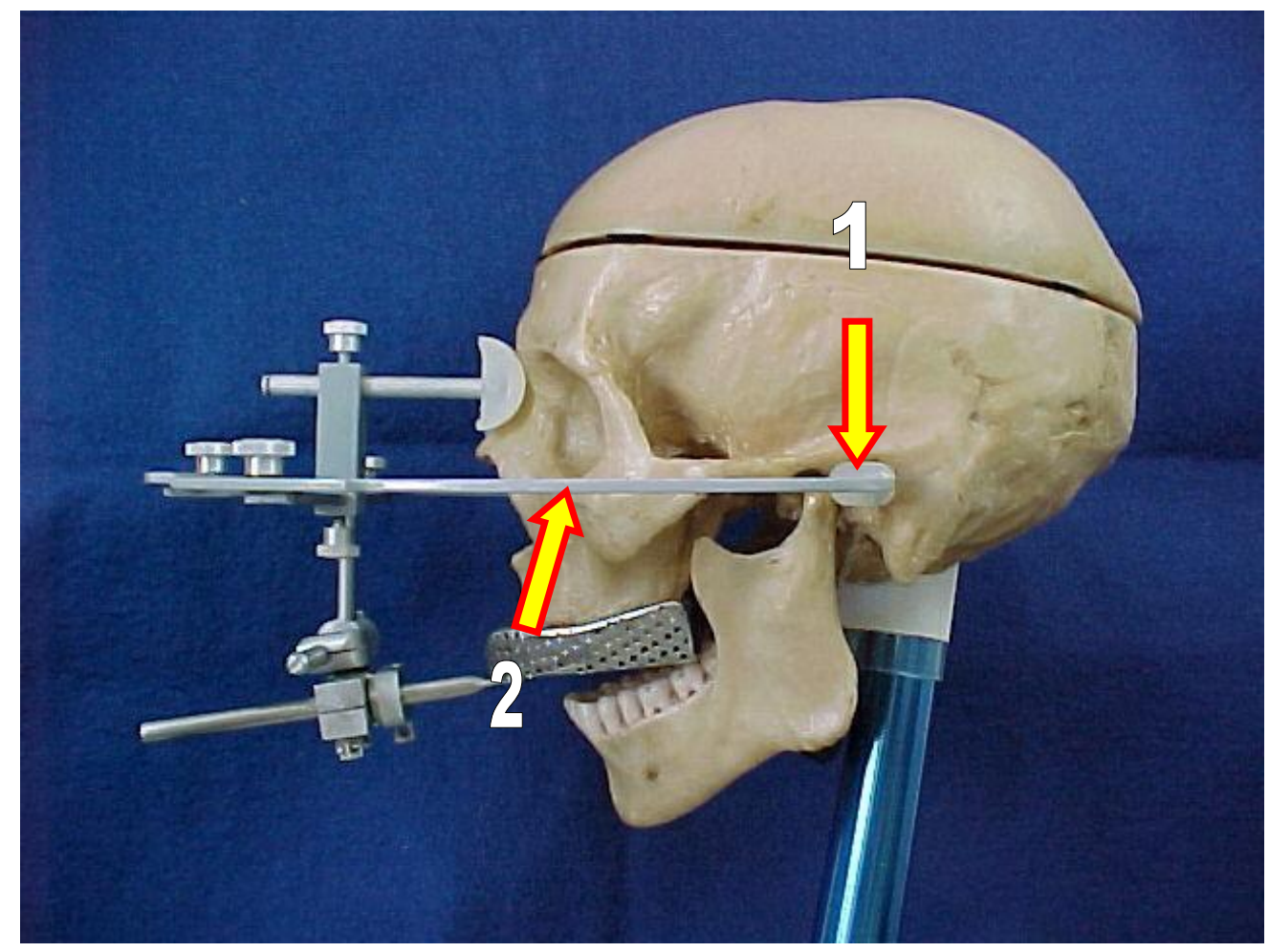

Figura 2.13 - 0 arco facial determina um plano de referência horizontal coincidente com o plano de Frankfurt, que vai do pórion (1) à porção inferior da cavidade orbital (2)

Beard \& Clayton (1981) afirmaram que o registro do eixo terminal de rotação da mandíbula pode ser transferido para os modelos de gesso montados em articulador permitindo assim, que os mesmos sejam ocluídos na mesma relação cêntrica encontrada no paciente.

Razek (1981) relatou que o registro do arco facial é um importante passo para a montagem apropriada de modelos de gesso na prática clínica em Odontologia protética.

Segundo Wise (1982) o arco facial é usado para registrar:

a) a distância das articulações temporomandibulares com os dentes superiores; 
b) o relacionamento entre o eixo do plano orbital (unindo-se ao eixo de rotação da mandíbula com a borda inferior da cavidade orbital, que corresponde ao plano de Frankfurt) e ao plano oclusal superior (unindo-se às pontas das cúspides dos dentes).

Para Chow et al. (1985) o relacionamento dos dentes com o eixo intercondilar da mandíbula e o plano horizontal é transferido para o articulador por meio do arco facial. Segundo os autores, na maioria dos articuladores semi-ajustáveis, o plano horizontal, no qual o modelo de gesso superior é orientado, é o plano de Frankfurt ou próximo dele, o plano axiorbital. Nesses tipos de articuladores, torna-se detalhe de grande valia se e quando a orientação dos modelos de gesso estiverem, no aparelho, de acordo com o eixo intercondilar e o plano horizontal, da mesma maneira que a maxila se relaciona com esses locais no paciente.

Palik et al. (1985) confirmaram que muitos erros em prótese dental podem ser atribuídos à montagem incorreta dos modelos do paciente. Os autores postularam que os registros do arco facial devem relacionar o modelo de gesso da maxila aos elementos condilares do articulador da mesma maneira que a maxila do paciente se relaciona com o eixo terminal de rotação dos côndilos da mandíbula. O trabalho desses autores demonstrou que o arco facial simples de posicionamento no meato acústico externo consegue relacionar a maxila ao eixo de rotação dos côndilos, em 50\% dos casos, dentro de uma área de $5 \mathrm{~mm}$ aceitáveis.

Para Piehslinger et al. (1985) os modelos de gesso da maxila montados no articulador são de grande importância diagnóstica, constituindo prática comum na Odontologia. Para isso, os modelos da arcada superior necessitam ter a mesma relação com o plano axiorbital do paciente. Para os autores, essa relação pode ser transferida do paciente para o articulador por meio do arco facial. No entender desses pesquisadores, a localização do eixo de rotação da mandíbula pode ser determinada 
por vários métodos cinemáticos e arbitrários. Os métodos arbitrários possuem alguma margem de erro, enquanto que o método mais preciso de montagem de modelos de gesso é realizado por meio da localização cinemática do eixo de rotação da mandíbula. No entanto, ponderaram os autores, o método arbitrário é o mais utilizado pela sua simplicidade e rapidez de manuseio. Em seus estudos esses autores avaliaram o efeito da montagem de modelos de gesso sobre o relacionamento maxilomandibular. Relativamente à mobilidade periodontal de $0,5 \mathrm{~mm}$ verificada em dentes sadios, definiram que o limite para um erro oclusal em prótese parcial fixa não deve exceder a 0,1mm. Esses autores citaram ainda o trabalho de Fox (1967) que afirmou que o limite de erros oclusais permitidos em prótese parcial fixa está entre 0,05 e $0,075 \mathrm{~mm}$.

Winstanley (1985) fez uma revisão da literatura a respeito do eixo de rotação da mandíbula e, no seu entendimento, o assunto da oclusão e dos movimentos mandibulares, embora tenha sido estudado por muitos anos, ainda não está completamente dominado.

Goska \& Christensen (1988) afirmaram em seu trabalho, que o arco facial é utilizado normalmente para a montagem dos modelos de gesso no articulador.

Em 1988, Strohaver \& Ryan verificaram que a maioria das faculdades de Odontologia, bem como os próprios profissionais, já indicavam o uso do arco facial quando havia necessidade de montagem de modelos de gesso em articulador. Esses autores afirmaram que o arco facial deve registrar o relacionamento entre a maxila e o eixo de rotação da mandíbula, estabelecendo o mesmo relacionamento entre o modelo de gesso superior e o eixo mecânico do articulador. Se o arco facial não for utilizado, as próteses construídas em modelos de gesso não montados em articulador de maneira precisa, podem exibir discrepâncias oclusais facilmente mensuráveis. 
No entendimento de Tamaki et al. (1990) a transferência dos modelos é um passo clínico importante que não pode ser negligenciado. $O$ essencial nesse procedimento é o correto posicionamento dos modelos de gesso que devem estar relacionados no espaço reservado a eles no articulador, tal qual estão os maxilares no contexto crânio facial.

Para Malone \& Koth (1991) e Mohl et al. (1991) as diferenças entre o posicionamento do modelo superior e o eixo de rotação da mandíbula, podem afetar a colocação das pontas de cúspides, fazendo com que as vertentes de cúspides de restaurações na região posterior contatem ou batam primeiro, quando o paciente fizer o movimento de fechar a boca e os dentes ocluírem. O uso do arco facial também impede as imprecisões rotacionais no plano horizontal, que podem causar relações oclusais incorretas.

Segundo Mohl et al. (1991) e Todescan et al. (1998) o arco facial deve transferir o modelo de gesso superior em relação ao eixo de rotação dos côndilos da mandíbula do paciente, fazendo com que o articulador mecanicamente seja equivalente ao mesmo. O eixo terminal de rotação é uma referência importante porque é reproduzível (Posselt, 1968). Isso irá permitir que o plano de oclusão do modelo superior seja corretamente orientado num espaço do articulador, comparável ao observado na maxila em relação ao plano de Frankfurt do paciente.

Bowley \& Bowman (1992) também demonstraram a possibilidade de erros oclusais se os modelos de gesso forem montados numa posição diferente daquela que as arcadas ocupam no paciente e poderão afetar o posicionamento oclusal das restaurações construídas dessa maneira.

Para ter-se uma noção exata da importância da determinação do eixo de rotação da mandíbula e do relacionamento dos modelos de gesso de acordo com esse 
eixo, pode-se citar o trabalho de Dawson, 1995, no qual ele definiu a relação cêntrica como sendo a precisa localização do eixo condilar horizontal quando os elementos côndilo-disco, apropriadamente alinhados, estão completamente assentados em suas respectivas cavidades articulares. Segundo o autor, devido a essa posição do eixo condilar horizontal determinar o relacionamento maxilomandibular durante $\mathrm{o}$ fechamento da mandíbula, qualquer variação na posição dos côndilos irá alterar o arco de oclusão da mandíbula e, assim, afetar o contato inicial dos dentes da mandíbula contra os dentes da maxila.

Castle \& Anthony (1998) realizaram uma interessante investigação para identificar qualquer alteração na dimensão vertical que pudesse ser atribuída a não utilização do arco facial. Os autores observaram alterações tanto nos casos onde o arco facial foi utilizado como naqueles em que não foi utilizado, porém demonstraram que uma maior alteração ocorreu nos casos onde não foi realizada uma transferência do modelo para o articulador utilizando o arco facial. Os autores preconizaram a necessidade de se realizar uma pesquisa mais aprofundada, com o objetivo de procurar estabelecer o quanto de alteração na dimensão vertical pode ser atribuída a erros técnicos no procedimento normal utilizando o arco facial. Para os autores o tempo gasto na transferência das informações posicionais da arcada superior para o articulador (eixo terminal de rotação) pode representar uma pequena porção do tempo requerido para concluir os ajustes oclusais numa prótese dental onde o arco facial não foi utilizado e, alertaram ainda, que essas informações iriam permitir ao clínico decidir sobre o tempo que estariam dispostos a dedicar nas correções oclusais junto ao paciente.

No entender de Todescan et al. (1998) para que o arco facial possa permitir ao operador alinhar adequadamente o modelo de gesso superior com o eixo terminal de 
rotação da mandíbula, são necessários três pontos de referência: dois posteriores (direito e esquerdo) e um anterior, de preferência na face. Para os autores, esse particular relacionamento espacial é muito importante, já que torna possível a fixação do modelo superior no articulador de modo individualizado.

Costa et al. (1999) apresentaram uma técnica de utilização do arco facial que aumenta a precisão de montagem dos modelos de gesso nos articuladores semiajustáveis provenientes do desenho do Whip Mix 8500.

\subsubsection{Tipos de dispositivos}

Palik et al. (1985) relataram em sua pesquisa, que os trabalhos existentes na literatura comparando os métodos arbitrários e cinemáticos de localização do eixo terminal de rotação da mandíbula são conflitantes. Os autores citaram Walker (1980) que observou que $20 \%$ do eixo de rotação verdadeiro detectado por meio de um localizador de eixo estava dentro de um raio de $5 \mathrm{~mm}$ da localização do eixo arbitrário situado $13 \mathrm{~mm}$ à frente do trágus (saliência cartilaginosa anterior à entrada do ouvido externo), enquanto que $60 \%$ estava a $6 \mathrm{~mm}$ ou mais. No entanto Schallhorn (1957) citado por Zuckerman (1982) que reportou que 95\% das localizações dos eixos verdadeiros encontra-se num raio de $5 \mathrm{~mm}$ do eixo arbitrário.

Segundo Strohaver \& Ryan (1988) o protótipo para todos os arcos faciais conhecidos atualmente surgiu com o dispositivo de Snow patenteado em 1899. A partir deste, basicamente foram desenvolvidos dois tipos de arcos faciais: o arbitrário e o cinemático. Enquanto o cinemático é usado para localizar realmente o eixo de rotação da mandíbula, a técnica arbitrária é razoavelmente mais rápida e considerada 
por muitos pesquisadores como sendo suficientemente precisa para os procedimentos rotineiros. Para esses autores, os pantógrafos já são considerados arcos faciais cinemáticos mais sofisticados, visto que conseguem registrar os movimentos mandibulares multidirecionais por meio de vários traçados pantográficos. Dentre esses encontram-se também os pantógrafos eletrônicos e os computadorizados.

De acordo com Mohl et al. (1991) e Todescan et al. (1998) existem vários tipos de arcos faciais: o arco facial simples, o cinemático e o pantográfico. Cada articulador vem normalmente acompanhado de seu arco facial com características próprias.

\subsubsection{Arco facial arbitrário simples}

Para a aplicação de arcos faciais arbitrários simples, existem diversos métodos de localização dos pontos condilares.

Weinberg (1959) citado por Thorp et al. (1978); Weinberg (1961); Hart et al. (1983) e Gordon et al. (1984) verificaram a presença de discrepâncias oclusais resultantes de erros na localização do eixo de rotação.

Para Pruden (1960) a montagem funcional de modelos de gesso, utilizando um arco facial arbitrário simples e um registro cêntrico interoclusal, é de considerável valor no diagnóstico e plano de tratamento de pacientes. Para o autor, com esse auxílio, a localização e o efeito de prematuridade na relação cêntrica pode ser estudada para ganhar melhor entendimento da oclusão do paciente.

Pode ser feita por simples palpação dos côndilos ou baseada no trágus. Neste caso, o ponto é demarcado arbitrariamente, baseado em médias anatômicas, a uma 
distância entre 11 e $13 \mathrm{~mm}$ anterior ao centro da borda superior do trágus, numa linha que vai deste à comissura palpebral lateral (canthus), segundo Weinberg (1963a). Para Teteruk \& Lundeen (1966) e Todescan et al. (1998) 13mm é a distância mais comum para esse tipo de técnica. Tamaki (1981), utilizou a média de $12 \mathrm{~mm}$ para a localização do côndilo. O terceiro ponto de referência é obtido na face do paciente, por meio de um pino do arco facial.

Teteruck \& Lundeen (1966); Shillingburg et al. (1983) e Todescan et al. (1998) descreveram os arcos faciais arbitrários simples que localizam os côndilos por meio do meato acústico externo, baseado em médias anatômicas.

Teteruck \& Lundeen (1966) analisaram o uso dos arcos faciais arbitrários de posicionamento no ouvido externo e concluíram ser de razoável precisão. Com uma simples modificação das olivas de plástico, no modelo convencional, eles conseguiram uma eficiência de 75,5\%. No estudo desses autores, constatou-se que 56,4\% dos pontos arbitrários obtidos pelo arco facial de aplicação no meato acústico externo, estavam dentro de um raio de $6 \mathrm{~mm}$ do eixo verdadeiro de rotação da mandíbula. Eles calcularam o epicentro da maior concentração de pontos do eixo verdadeiro e modificaram a posição dos orifícios de montagem das olivas para novo centro, conseguindo-se sensível melhoria na localização do eixo de rotação pelo método arbitrário. Para os autores a localização arbitrária do eixo de rotação é o método mais comum utilizado. A precisão, velocidade de manuseio e simplicidade de orientar o modelo maxilar com esse tipo de arco facial de posicionamento no meato acústico externo são recomendações para seu uso em muitos procedimentos restauradores.

Fox (1967) demonstrou que a localização arbitrária do eixo de rotação da mandíbula é aceitável para a maioria dos procedimentos odontológicos. 
Hickey et al. (1967) descreveram o arco facial de montagem rápida (quick mount) da Whip Mix Co., que foi concebido para utilizar o meato acústico externo como meio de desenvolver um eixo arbitrário de rotação.

Bonfante et al. (1974) esclareceram em seu estudo que não é indispensável o uso de aparelhagem sofisticada para a montagem com o eixo terminal de rotação dos côndilos da mandíbula do paciente.

Para Tanaka et al. (1975) esse tipo de arco facial utiliza o meato acústico externo como um meio de localizar o eixo de rotação arbitrário. Segundo os autores, esses arcos faciais apresentam pequenas esferas, também chamadas de olivas, nas extremidades de cada metade do arco, as quais são introduzidas nos meatos auditivos externos. Nas olivas existem orifícios que são adaptados sobre os pinos existentes nas guias condilares que estão a $6 \mathrm{~mm}$ do verdadeiro eixo terminal de rotação. Esse arco facial é o mais utilizado com os articuladores semi-ajustáveis.

Hobo et al. (1976) relataram a utilização de arcos faciais simples para a transferência de informações posicionais da arcada superior para o articulador.

Os arcos faciais simples que utilizam o meato acústico externo demonstram ter, segundo Whitsett et al. (1977) um relativo alto grau de precisão, com 75,5\% de acerto na localização do eixo de rotação. Segundo esses autores, o uso do arco facial arbitrário pode ser empregado na maioria dos casos.

Loos (1978) atestou que muitos procedimentos clínicos não requerem o alto grau de precisão fornecido pelos arcos cinemáticos, sendo que um simples arco facial arbitrário seria suficiente. Relatou, ainda, que os arcos de posicionamento no meato acústico externo são melhores na localização do eixo de rotação da mandíbula em relação aos do tipo Snow, em que são necessárias medidas externas, marcações na 
pele e cálculos para essa localização. Para esse autor o mais largamente utilizado é o Whip Mix de montagem rápida.

Para Hockel (1980) o arco facial arbitrário adota na fixação dos pontos de referência posteriores para a determinação do plano horizontal, os meatos acústicos externos utilizados para localização do eixo de rotação da mandíbula e, como terceiro ponto, uma distância predeterminada inferiormente ao násion. Para o autor, são essenciais dispositivos de medida para planejar e registrar um tratamento, para avaliar, diagnosticar, planejar e verificar o progresso do tratamento em detalhes.

Walker (1980) no entanto, afirmou que a localização do eixo de rotação arbitrário para a maioria da população não existe e que, a maioria dos eixos recomendados na literatura criam uma margem de erro de aproximadamente $6 \mathrm{~mm}$.

Palik et al. (1985) estudaram os arcos faciais de posicionamento no meato acústico externo e demonstraram ser um dispositivo de importância para o desenvolvimento de registros interoclusais. Segundo os autores, esses dispositivos relacionam a maxila com o eixo terminal de rotação da mandíbula dentro dos $5 \mathrm{~mm}$ aceitáveis, em 50\% das vezes. Esses dispositivos registram o eixo arbitrário anterior ao eixo terminal de rotação em $92 \%$ dos casos.

No entendimento de Gordon \& Stoffer (1985) a ausência de desvio lateral imediato e a seleção da guia canina são fatores que sugerem a possibilidade do uso de um articulador semi-ajustável.

Para Ellis III et al. (1992) o uso do arco facial arbitrário pode ser indicado pois fornece um eixo de rotação dentro de um raio de 5mm, que é aceitável. Para defender essa afirmação, os autores citaram o trabalho de Schallhorn (1957), que estudou o centro de rotação arbitrário e cinemático da mandíbula. 
Todescan et al. (1998) descreveram o uso dos arcos faciais simples para uso em reabilitação oral.

Costa (1998) e Costa et al. (1999) demonstraram uma melhor precisão de montagem utilizando um arco facial arbitrário simples, por meio de um dispositivo desenvolvido para ser acoplado ao arco facial (Figura 2.14). Os autores observaram a presença de desvios de posição do modelo de gesso superior fixado ao garfo de mordida, causados pela formação de uma alavanca (Kneip et al., 1951), devido ao apoio do arco facial sobre a mesa incisal do ramo inferior dos articuladores semiajustáveis do tipo arcon.

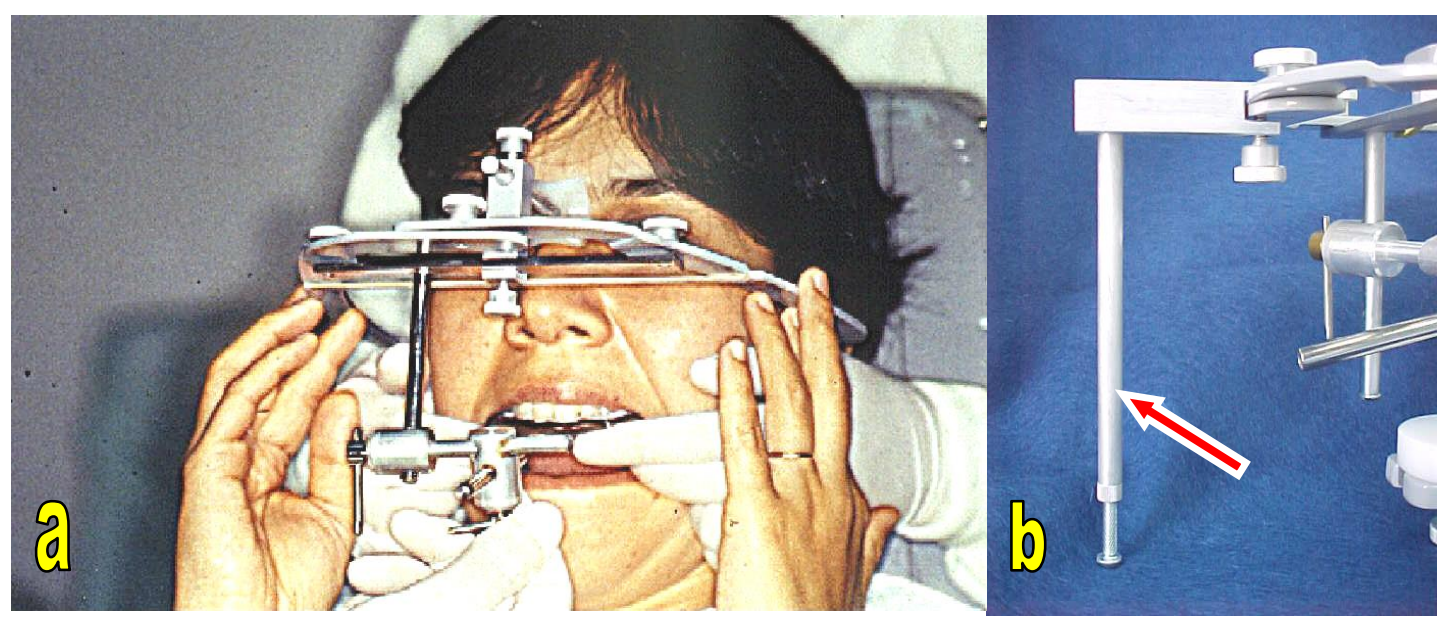

Figura 2.14 - (a) arco facial simples de posicionamento no meato acústico externo; (b) detalhe do dispositivo denominado de suporte anterior do arco facial (seta), que permite a manutenção da posição de registro da arcada superior para a montagem do modelo de gesso

Segundo Bowley \& Morgano (2001) o arco facial arbitrário é considerado aceitável para o tratamento do paciente. 


\subsubsection{Arco facial cinemático}

Para Hockel (1980) o arco facial cinemático utiliza, para a determinação do plano horizontal, dois pontos de referência cinematicamente localizados na posição terminal de rotação da mandíbula e um ponto infra-orbitário do lado direito.

Segundo Stade et al. (1982) o desenvolvimento da técnica de localização cinemática do eixo de rotação da mandíbula é atribuída a McCollum em 1939 e Stuart em 1955. Eles também demonstraram que os eixos podem estar localizados assimetricamente na cabeça do paciente, o que pode levar a incorreções no uso de arcos faciais convencionais. Isso pode resultar em planos oclusais e incisais inclinados de maneira imprópria. Segundo esses autores, o efeito na oclusão causado por modelos de gesso incorretamente montados em articulador devem ser mais bem estudados.

Todescan et al. (1998) esclareceram que o arco facial cinemático é utilizado para a localização do eixo terminal de rotação da mandíbula e também para transportar e orientar a fixação dos modelos, mantendo as mesmas relações da boca no articulador. O mais convencional é composto por dois conjuntos, um correspondente à arcada superior e outro à inferior. Nas extremidades direita e esquerda do arco inferior, ficam os estiletes localizadores ou inscritores e nas extremidades do arco superior, as chamadas bandeiras, onde são registrados os pontos de emergências do eixo terminal de rotação virtual.

Ainda segundo os autores, a fixação do arco facial cinemático à arcada dental se faz, normalmente, por meio de um dispositivo acoplador ou de engate chamado “clutch" semelhante a uma moldeira especial metálica, a qual é desmontável por meio de parafusos (Figura 2.15). 


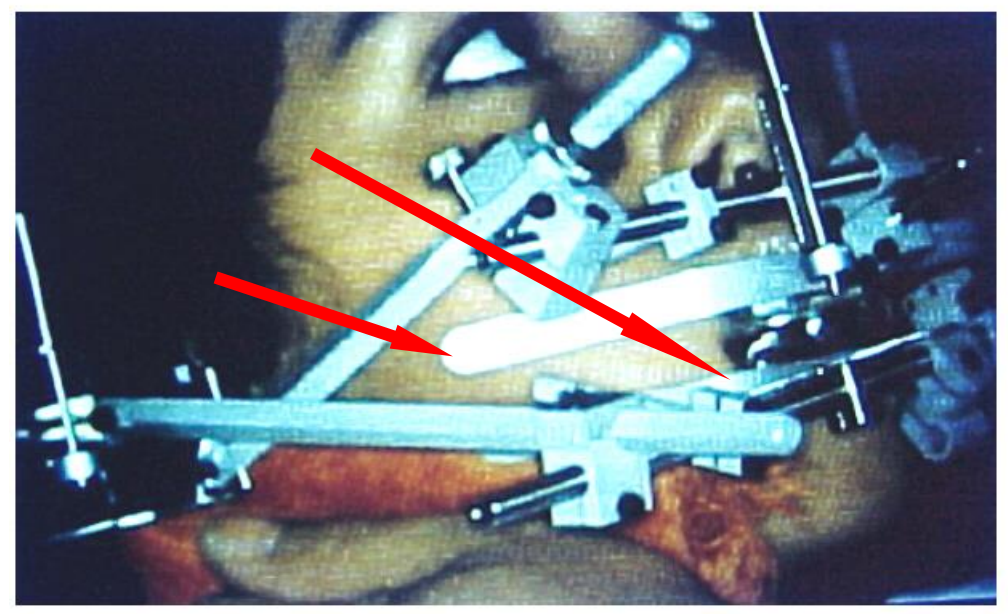

Figura 2.15 - Arco facial cinemático acoplado a um clutch (setas) (extraído do livro de Todescan et al., 1998)

Bowley \& Morgano (2001) afirmaram em seu trabalho que o arco cinemático é utilizado para uma localização mais precisa do eixo de rotação transversal dos côndilos da mandíbula do paciente, porém, reservados para os casos em que deverá ser introduzida uma alteração da dimensão vertical de oclusão.

\subsubsection{Arco facial pantográfico}

Em 1973, Moberg et al., propuseram o uso do pantógrafo como um instrumento para registrar os movimentos da mandíbula e também como um arco facial de precisão para transferência do modelo da maxila para o articulador. 
De acordo com Tamaki (1976) o pantógrafo é um dispositivo sofisticado que determina as trajetórias sagitais dos côndilos, trajetória incisal, ângulos de Bennett, ângulos de Fischer e a distância intercondilar funcional do paciente, por meio de traçados inscritos sobre plataformas de registro fixadas à porção correspondente à mandíbula e com puas registradoras fixadas no arco superior do instrumento. Segundo o autor, esse dispositivo de precisão foi proposto por McCollum em 1939, com o nome de gnatógrafo.

Shillingburg et al. (1983) orientaram que para se conseguir uma simulação fiel dos movimentos condilares num articulador, é necessário obter certos traçados, de maneira precisa, das trajetórias percorridas pelos côndilos. Isso pode-se conseguir com um máximo de precisão mediante o uso de um pantógrafo, que captará todas as características dos movimentos excêntricos da mandíbula, desde sua posição retrusiva até sua posição protrusiva e laterais máximas.

Shillingburg et al. (1983) e Todescan et al. (1998) descreveram o pantógrafo como sendo um dispositivo que, de maneira semelhante ao arco cinemático, possui um conjunto de dois arcos faciais. Um está fixo à arcada superior e o outro à inferior, mediante uma moldeira que se prende aos dentes. No arco inferior são fixadas guias ou puas registradoras, bilateralmente, nas proximidades do eixo terminal de rotação dos côndilos da mandíbula (uma vertical e outra horizontal, Figura 2.16, a) e, também, outras duas verticais na parte anterior do aparelho, uma de cada lado da linha mediana (Figura 2.16, b). No arco superior são fixadas, nas proximidades do eixo terminal de rotação dos côndilos da mandíbula, duas pequenas plataformas opostas às guias (uma vertical e outra horizontal), onde os registros serão realizados (Figura 2.16, c ). Também existem outras duas plataformas na parte anterior, uma de cada lado da linha mediana, opostas às guias inscritoras (Figura 2.16,d). 


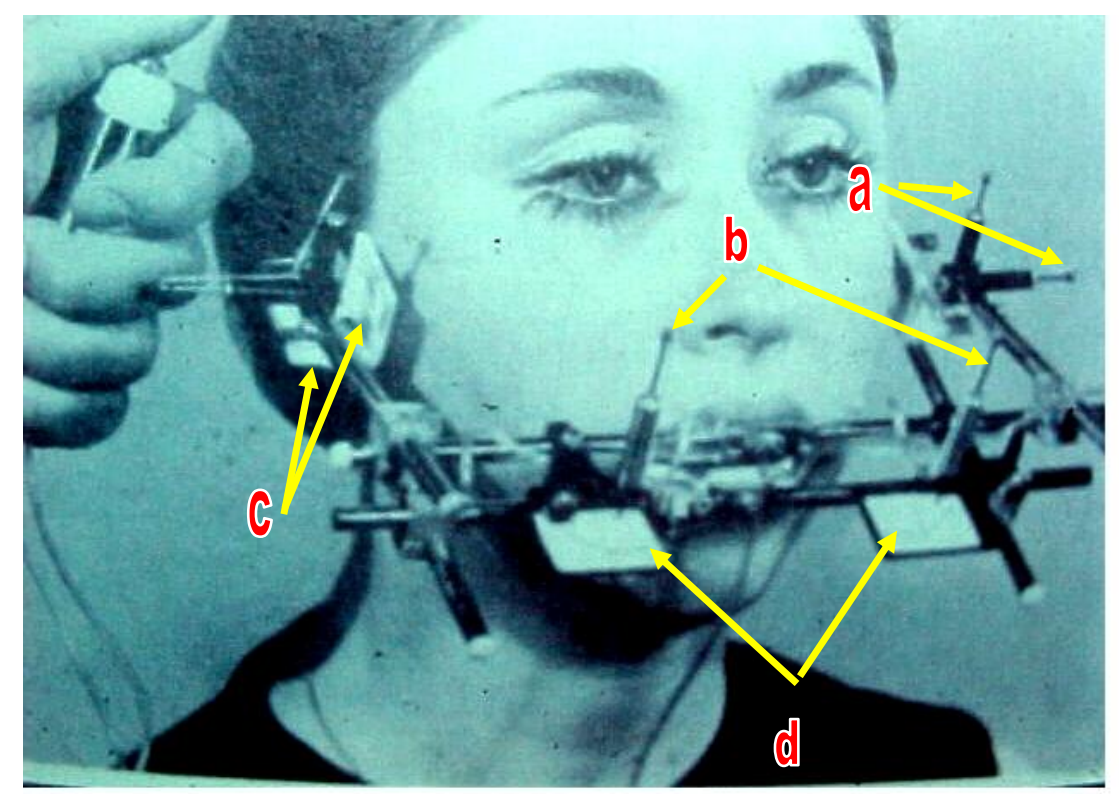

Figura 2.16 - Arco facial pantográfico: (a) puas registradoras posteriores; (b) puas registradoras anteriores; (c) plataformas de registro posterior e, (d) plataformas de registro anterior

Ainda segundo Shillingburg et al. (1983) e Todescan et al. (1998) a mandíbula é submetida à uma série de movimentos laterais, direito e esquerdo, assim como deslocamentos protrusivos. As guias dos arcos vão registrando as trajetórias seguidas pelos côndilos, em cada um de seus movimentos. Todo o potencial do pantógrafo é obtido quando associado a articuladores totalmente ajustáveis.

Para Anderson et al. (1987) os pantógrafos registram os movimentos mandibulares em três dimensões utilizando um estilete inscritor e mesas de registro fixadas às arcadas dentais por meio de um dispositivo de engate ou acoplador do pantógrafo. Para esses autores, diversos estudos com pantógrafos eletrônicos e computadorizados mostram que esses instrumentos são precisos e confiáveis em registrar os movimentos mandibulares. 
Kolling et al. (1988) também analisaram a validade de um sistema computadorizado na pesquisa dos movimentos mandibulares e demonstraram tratar-se de um método efetivo e preciso para se detectar diferenças entre traçados pantográficos superiores a $0,1 \mathrm{~mm}$.

Hayashi et al. (1994) verificaram em seu estudo que é possível reproduzir-se eletronicamente a oclusão do paciente, porém ainda é um método que consome muito tempo e muitas vezes pode perder a precisão para os métodos convencionais. No dizer desses autores, os métodos robotizados para se determinar eletronicamente a oclusão do paciente foram inicialmente desenvolvidos por Messerman (1967) citado por Hayashi et al. (1994).

Leknius (1996) analisou e melhorou a utilização de um pantógrafo eletrônico que, no entendimento do autor, simplificou grandemente o processo de transferência de informações para os articuladores totalmente ajustáveis. 


\section{PROPOSIÇÃO}

A proposição desse trabalho é comparar duas técnicas de montagem quanto a capacidade que cada uma possui em posicionar o modelo de gesso superior corretamente no articulador. O parâmetro a ser utilizado nesta pesquisa é o ângulo formado entre o plano de Frankfurt e o plano oclusal do paciente, sendo que o ângulo formado entre o ramo superior do articulador e o plano oclusal dos modelos montados na técnica convencional e na técnica de transferência direta do molde, serão comparados a ele. 


\section{MATERIAL E MÉTODOS}

Este capítulo foi dividido em quatro tópicos que serão analisados da seguinte forma: 4.1 Considerações gerais; 4.2 Treinamento e calibração dos operadores; 4.3 Material; 4.4 Métodos.

\subsection{Considerações gerais}

A investigação ora preconizada foi desenvolvida na clínica da Faculdade de Odontologia da Universidade Cidade de São Paulo (UNICID), em conformidade com a resolução do Conselho Nacional de Saúde (CNS), do Ministério da Saúde, no ${ }^{\circ} 196$ de 10 de outubro de 1996 e foi submetida à apreciação da Comissão de Ética em Pesquisa (CEP) dessa Universidade, tendo recebido parecer favorável a sua realização (Anexo 1).

Para a fundamentação deste trabalho, foi utilizada uma paciente do sexo feminino, 39 anos, portadora de arcada dentária superior de Classe I de Kennedy (desdentado posterior bilateral) e sem sinais e sintomas subjetivos de desordens temporomandibulares, que concordou com o teor do termo de consentimento livre e esclarecido (Anexo 2), e recebeu a montagem do arco facial pelas duas técnicas (Figura 4.1). 


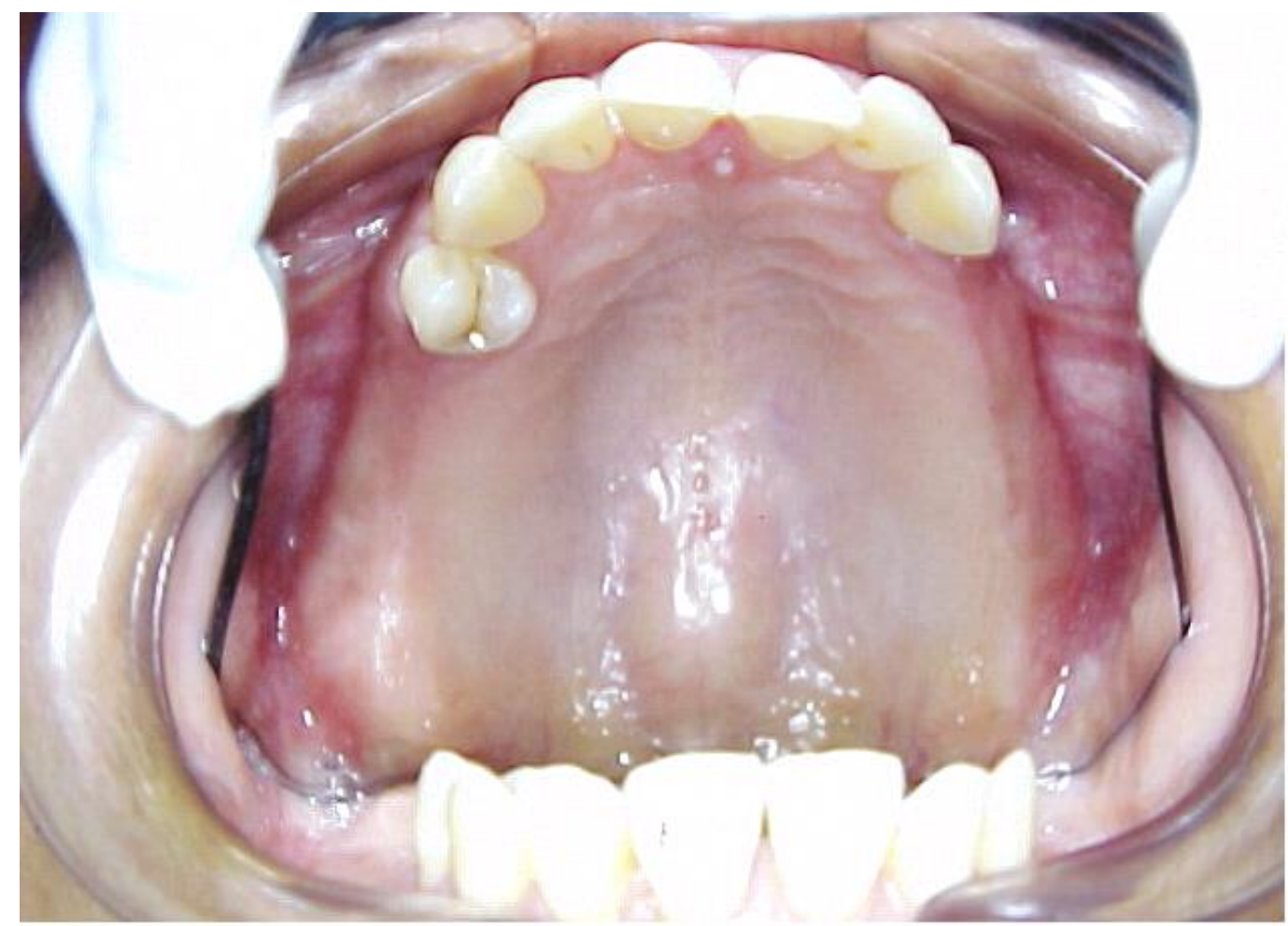

Figura 4.1 - Arcada superior de Classe I de Kennedy, utilizada na pesquisa

Os determinantes pelos quais realizou-se a pesquisa com apenas uma paciente serão convenientemente embasados mais adiante por antecedentes científicos encontrados na literatura.

Vale lembrar que a proposta dessa pesquisa é comparar duas técnicas de montagem quanto a capacidade que cada uma possui em reproduzir o ângulo formado 
entre o plano de Frankfurt e o plano oclusal da paciente, comparando-o com o ângulo formado entre o ramo superior do articulador e o plano oclusal dos modelos montados na técnica convencional, assim denominada por ser largamente descrita na literatura, e na técnica de transferência direta do molde. Por este motivo a fixação do modelo inferior à placa de montagem do ramo inferior do articulador não foi efetivada.

As técnicas que foram comparadas possuem metodologia distinta. Para se fixar o modelo de gesso na técnica convencional e, especificamente no caso da arcada dentária de Classe I de Kennedy, utilizada nessa pesquisa, necessita-se de no mínimo duas sessões clínicas e duas laboratoriais para que a montagem seja concluída. $\mathrm{Na}$ primeira sessão clínica molda-se o paciente. O paciente é dispensado e na primeira sessão laboratorial é necessário que o molde seja vazado, aguardando-se aproximadamente 40 minutos para a cristalização do gesso e depois, no caso de edentados parciais, confecciona-se a base de registro e o rolete de cera para a obtenção do plano de orientação, cuja confecção será detalhada mais adiante. Na segunda sessão clínica ajusta-se o plano de orientação na boca do paciente, quanto as suas bordas e dimensão vertical e, somente então, procede-se ao registro do arco facial na face do paciente. Após esta consulta, na segunda sessão laboratorial montase o modelo superior no articulador.

Na técnica de transferência direta, o molde é vazado imediatamente após ser removido da boca, obtendo-se dessa maneira, o modelo montado numa só etapa.

Fica evidente que na técnica convencional, a paciente teria que ser submetida a uma série muito maior de procedimentos clínicos para se obter a montagem do modelo de gesso.

O Conselho Nacional de Saúde (CNS) deixa claro que deve-se sempre estar assegurado não ser possível estabelecer as vantagens de um procedimento sobre outro 
por meio de revisão da literatura, métodos observacionais ou métodos que não envolvam seres humanos. Como essa investigação necessita de uma aplicação clínica, procurou-se cumprir o parágrafo $h$ do capítulo III.3 da Resolução do CNS n ${ }^{\circ} 196$ de 10 de outubro de 1996, já mencionada anteriormente, a fim de garantir o bem-estar do sujeito da pesquisa e adequar as duas técnicas utilizadas ao projeto proposto, deixando a técnica convencional no mesmo passo clínico da técnica convencional.

Com esse intuito seguiu-se a metodologia que será descrita nos capítulos seguintes.

É importante ressaltar ainda, que todos os procedimentos utilizados para a efetivação das montagens dos modelos de gesso superiores nos articuladores, em ambas as técnicas estudadas, foram considerados suficientemente precisos. Somente a transferência do ângulo formado entre o plano oclusal e o de Frankfurt para o articulador foi avaliada.

\subsection{Treinamento e calibração dos operadores}

Para a realização das montagens em articulador, foram convidados dez profissionais (operadores) com experiência no uso desses instrumentos. Cada um recebeu um conjunto de instrumentais básicos para utilização nas duas técnicas, os quais serão relacionados no item de instrumentais utilizados.

Também foram fornecidos aos profissionais, com a finalidade de padronizar os procedimentos realizados, os materiais necessários que constam de uma listagem especificada no item de materiais de consumo. Nessa listagem também constam os 
materiais utilizados para a obtenção dos modelos padronizados utilizados na técnica convencional e para a confecção dos planos de orientação.

Uma semana antes do início do estudo, os operadores foram treinados a realizar as técnicas de montagem. Com esta finalidade, foram realizadas duas montagens no articulador 01, uma convencional (C01) e outra pela técnica direta (Z01), como demonstração da metodologia a ser seguida e, também, servindo de controle.

Cada operador recebeu um protocolo (descrito nos itens 4.4 .2 e 4.4.4), contendo as instruções a serem seguidas durante a montagem convencional e de transferência direta.

\subsection{Material}

\subsubsection{Instrumentais utilizados}

Para este trabalho foram utilizados os seguintes instrumentais básicos:

1) 20 articuladores semi-ajustáveis do tipo arcon, marca Dent-Flex 10.600 (DentFlex Ind. e Com. Ltda., Brasil) (Figura 4.2). 


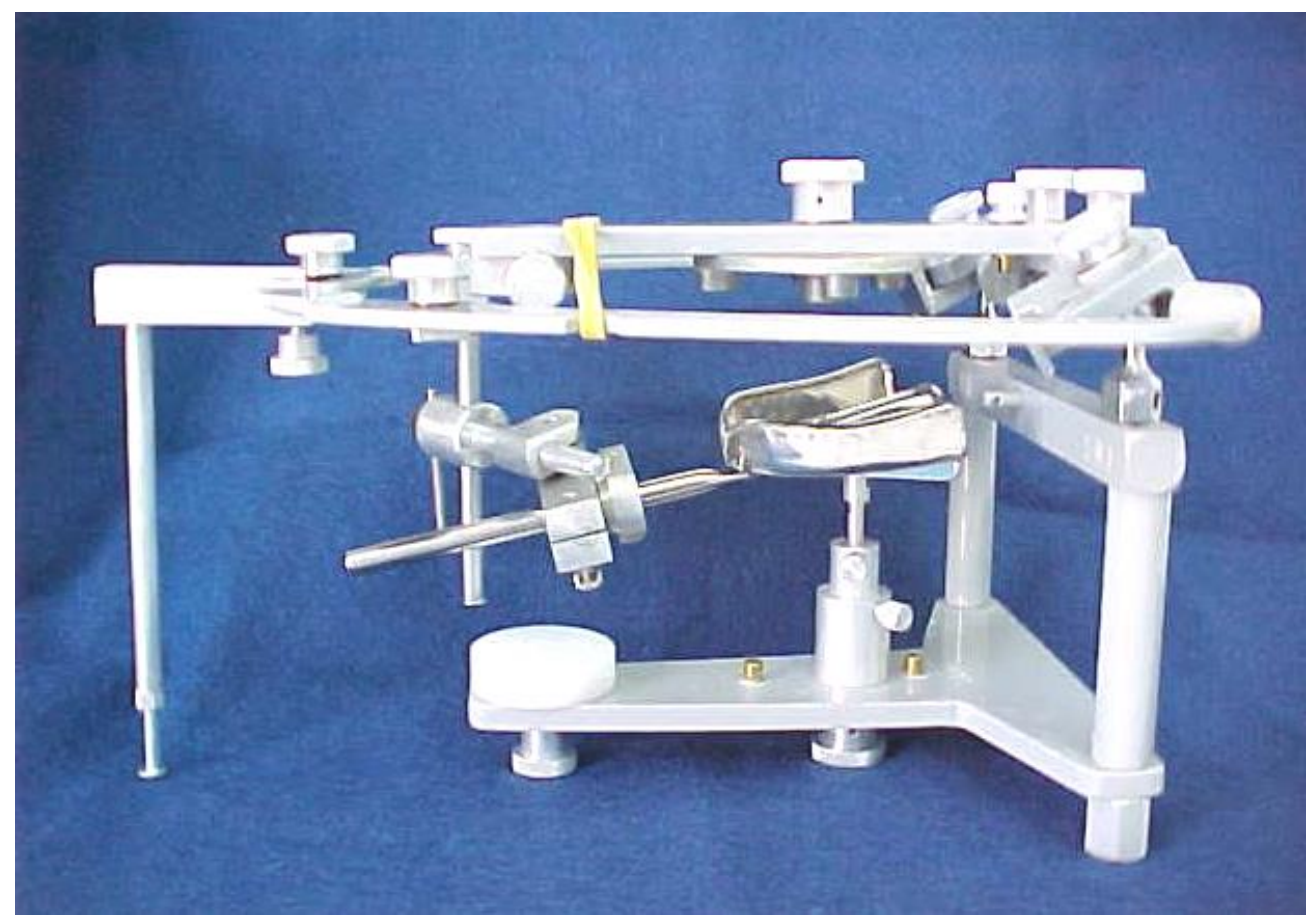

Figura 4.2 - Articulador arcon semi-ajustável com arco facial arbitrário simples utilizado na pesquisa

2) 20 conjuntos de moldeira de transferência Zanetti (Teccom Ind. Com. Equip. Ltda., Brasil) (Figura 4.3).

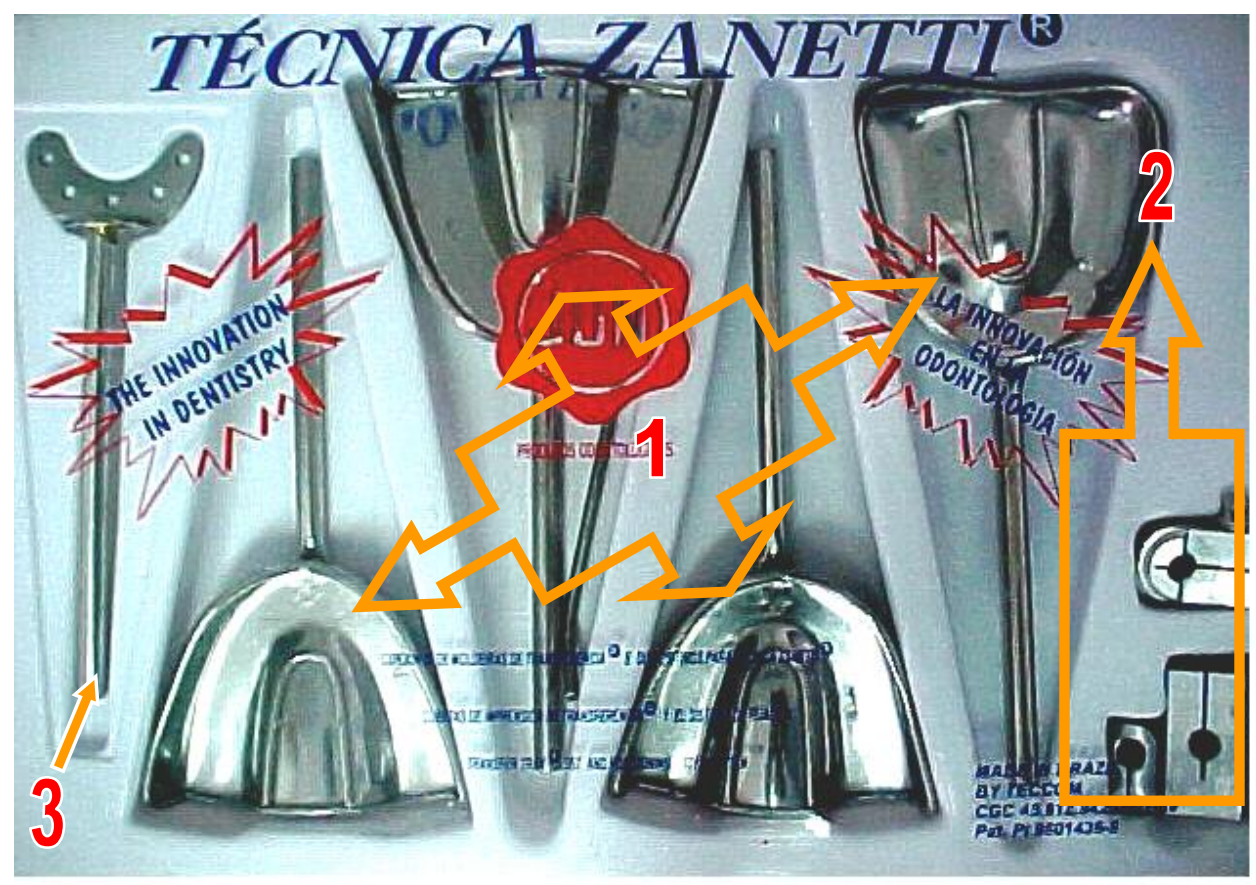

Figura 4.3 - Conjunto de moldeiras de transferência: (1) moldeiras; (2) sistema de fixação da moldeira no arco facial e, (3) cabo para moldeira funcional de transferência 
3) 20 conjuntos de suportes Ribas (Dent-Flex Ind. e Com. Ltda., Brasil) (Figura 4.4).

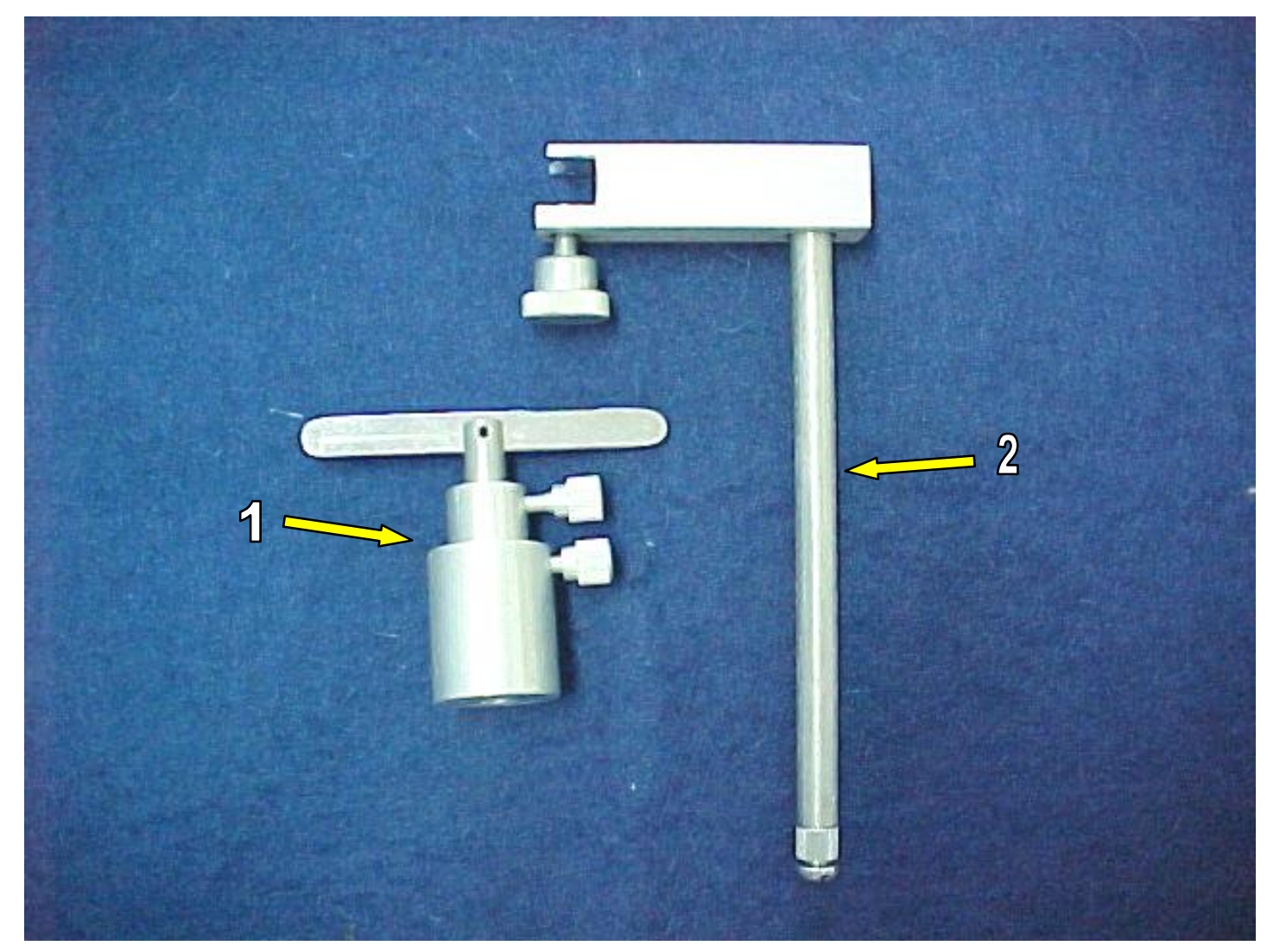

Figura 4.4 - Conjunto de suportes Ribas: suporte inferior da moldeira ou garfo (1) e suporte anterior do arco facial (2)

\subsubsection{Materiais de consumo}

Para padronizar os procedimentos realizados para a moldagem e montagem dos modelos de gesso no articulador, foram fornecidos aos profissionais os seguintes materiais complementares, cujas marcas comerciais serão citadas ao longo da descrição de cada procedimento realizado: 
1) resina incolor de rápida polimerização (monômero e polímero).

2) pote de resina com tampa.

3) 02 potes Dappen.

4) isolante para gesso.

5) pincel $n^{\circ} 18$.

6) espátulas $n^{\circ} 7$ e 31 .

7) mandril para tira de lixa e disco.

8) fresa de carbeto de tungstênio e pontas montadas para resina.

9) pedra branca para resina em forma de pêra.

10) pedras montadas verdes.

11) disco de carboneto de silício.

12) micromotor com ponta reta.

13) lamparina comum e de chama dirigida (tipo Hanau).

14) plastificador de cera/godiva.

15) isqueiro.

16) cera $\operatorname{rosa} n^{0} 7$.

17) placa conformadora de plano oclusal.

18) placa de vidro.

19) régua milimetrada flexível.

20) vaselina sólida.

21) alginato.

22) silicone de adição.

23) borracha de silicone.

24) godiva de média fusão.

25) pasta de óxido de zinco e eugenol. 
26) gesso comum.

27) gesso pedra especial microgranulado.

28) umidificador de gesso (Tuppeware com tampa).

29) gral de borracha.

30) espátula para gesso.

31) fio ortodôntico de $0,6 \mathrm{~mm}$.

32) alicates de bico chato e de corte.

33) papel fotográfico e ultraphan

34) lápis, transferidor e esquadro

\subsection{Métodos}

\subsubsection{Metodologia utilizada para obtenção do modelo-padrão e preparo para a montagem pela técnica convencional}

Inicialmente a arcada superior da paciente foi moldada com um material de moldagem à base de alginato tixotrópico isento de pó (dust free), de presa rápida (Hydrogum, Zhermack® S.p.A., Itália).

Foi escolhida a moldeira $\mathrm{n}^{\mathrm{o}} 4$ do sistema de moldeiras de transferência direta Zanetti, que é indicada para desdentado posterior bilateral. A moldeira foi devidamente individualizada com cera rosa $\mathrm{n}^{0} 7$ (Wilson, Polidental Ind. e Com. Ltda., Brasil) segundo a técnica descrita por Zinner, 1987, com a finalidade de minimizar as variáveis decorrentes de diferentes espessuras do material de moldagem. Após o amolecimento em plastificador elétrico com água a $55^{\circ} \mathrm{C}$ (Mari-Jós Ind. e Com., Brasil) a cera foi inicialmente colocada na região da moldeira correspondente 
ao palato. Nesse procedimento de acomodação da cera na moldeira, também fez-se uso de uma tocha de chama dirigida (Hot Shot, Blazer Co., USA). Após um banho homogeneizador no plastificador, a moldeira foi colocada na boca da paciente para adaptação da cera à anatomia da região do palato. Na seqüência, a cera foi colocada em toda a extensão dos rebordos residuais até o fundo de sulco vestibular. Procedeuse da mesma maneira que na região do palato. Esse procedimento foi repetido várias vezes até que a cera estivesse adequadamente adaptada ao palato, rebordos residuais e fundo de sulco vestibular. Na região do bordo anterior da moldeira foi colocada cera periférica (Kota Ind. e Com. Ltda., Brasil) plastificada com auxílio da tocha de chama dirigida e homogeneizada em plastificador a $55^{\circ} \mathrm{C}$, sendo a moldeira colocada na boca da paciente para adaptação da cera ao fundo de sulco vestibular. Removeu-se uma camada de $3 \mathrm{~mm}$ de cera da região dos rebordos e palato para propiciar uma espessura uniforme ao material de moldagem (Valderhaug \& Flфystrand, 1984; Mendez, 1985). Para promover a retenção do alginato à cera, foram feitas ranhuras em toda a extensão da cera.

$\mathrm{Na}$ execução da moldagem propriamente dita, o pote de alginato foi virado de fundo para cima umas duas ou três vezes, para homogeneizar os componentes do pó que se sedimentam. Para a moldeira escolhida foram utilizadas três porções do pó para três medidas de água à temperatura ambiente, sendo que a colher e o medidor de água são utensílios fornecidos pelo fabricante. Primeiramente foi colocada a quantidade de pó necessária e depois a água. A mistura foi espatulada por 30 segundos e colocada na moldeira. Ao mesmo tempo pediu-se à paciente para fazer bochechos com água morna para remoção da saliva mais mucilaginosa. A moldeira foi inserida na boca e comprimida suavemente até sua correta posição. Assim 
permaneceu durante 60 segundos após o desaparecimento da viscosidade e brilho superficial do alginato

Todo o cuidado foi tomado nessa moldagem, para obter-se uma espessura uniforme do material de moldagem, desse modo melhorando a exatidão do modelo de gesso obtido, como ensinou Breeding et al. (1994) em seu trabalho.

Seguindo as orientações do trabalho de Mendez (1985) e com o intuito de aumentar a resistência do modelo, o molde assim obtido foi vazado com gesso pedra especial microgranulado (Durone, Dentsply Ind. e Com. Ltda., Brasil) de endurecimento rápido. A proporção água/pó utilizada foi a mesma sugerida pelo fabricante: $100 \mathrm{~g}$ de pó para $19 \mathrm{ml}$ de água a temperatura ambiente. Primeiramente foi colocada a água e depois o pó foi incorporado durante 30 segundos, com auxílio de uma espátula para gesso. A massa homogênea foi espatulada por 30 segundos, sendo o gral em seguida colocado no vibrador para eliminação de bolhas de ar do gesso. Logo após foi vazado o molde, ainda sob vibração. Deixou-se o gesso cristalizar por 60 minutos com a moldeira apoiada no interior de um umidificador. Depois da cristalização do gesso, o modelo foi retirado do molde e recortado em máquina própria para recortar gesso.

Esses procedimentos estão devidamente ilustrados no capítulo 4.4.4, página 96.

Com esse modelo previamente acabado, foi realizada uma transferência da posição da maxila da paciente para o articulador por meio do arco facial, apenas para ajustar a altura que a base do modelo deveria ter com a finalidade de tornar-se um modelo-padrão (Figura 4.5) e, assim, pudesse ser duplicado com o tamanho apropriado para que suas cópias pudessem ser posicionadas no espaço compreendido 
entre o garfo de mordida do arco e a placa de montagem do ramo superior do articulador, sem interferências.

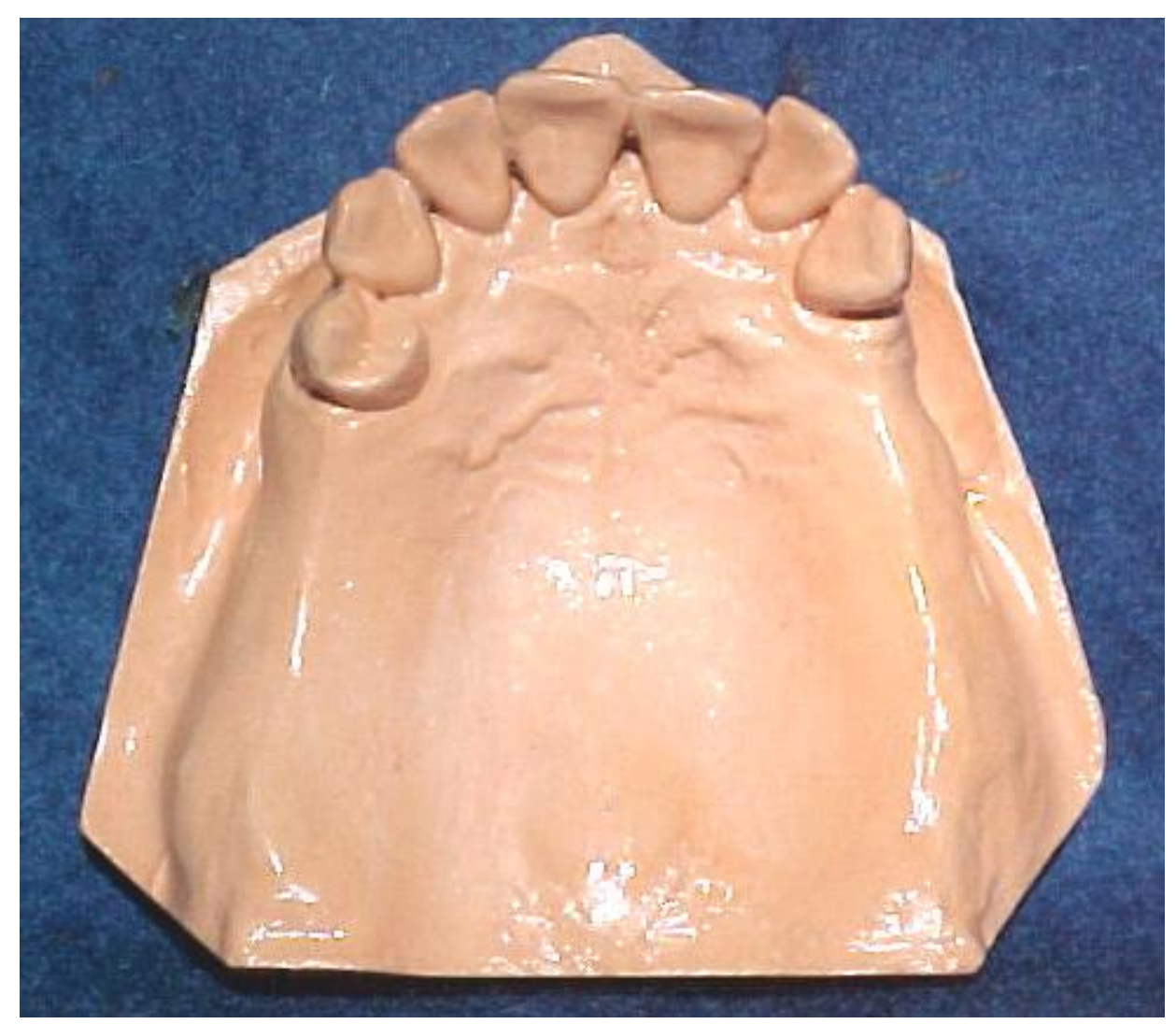

Figura 4.5 - Modelo-padrão utilizado para a duplicação dos modelos para a técnica convencional

Para permitir o ajuste do posicionamento do modelo no articulador, utilizou-se uma placa de registro oclusal confeccionada em cera rosa ${ }^{\circ} 7$ (Wilson, Polidental Ind. e Com Ltda., Brasil) no tamanho da arcada superior da paciente e com dois blocos ou roletes com o mesmo tipo de cera, um para cada espaço protético posterior, com a altura aproximada do plano oclusal da paciente. Esse plano de orientação em cera, assim confeccionado, foi plastificado em água morna a $55^{\circ} \mathrm{C}$ em plastificador elétrico (Plastificador de godiva, Mari-Jós Ind. e Com., PR, Brasil) e colocado na 
boca da paciente para estabelecer sua altura e obter a impressão das pontas de cúspide dos dentes remanescentes. Resfriou-se o plano de orientação com jatos de água.

Em seguida o arco facial foi posicionado na paciente colocando-se o garfo do arco sob o registro realizado em cera. Após os ajustes necessários, o arco foi removido da face da paciente, bem como o plano de orientação em cera. Colocou-se o arco no articulador e o modelo de gesso com o plano de orientação em cera em posição. Dessa forma foi possível verificar os recortes necessários a fim de remover as interferências do modelo no espaço do articulador reservado a sua montagem.

É conveniente observar que o uso de roletes de cera para o registro sem o suporte de uma base rígida, como proposto por Ogesen (1968) é condenado por vários pesquisadores na literatura, devido à instabilidade desse material e a possibilidade de não ficar firmemente aderido em seu local próprio. A técnica descrita acima foi utilizada somente para se verificar o tamanho apropriado do modelo ao espaço entre o garfo de mordida do arco facial e a placa de montagem do ramo superior.

Após esse ajuste, o modelo-padrão foi isolado com um verniz a base de metil metacrilato (monômero Jet, Clássico Art. Odontol., Brasil) e poliestireno cristal (plástico), com o objetivo de fornecer uma superfície lisa livre de porosidades, além de preservar o aspecto intrínseco da superfície.

Na seqüência, foram obtidos dois moldes do modelo-padrão por meio de uma borracha de silicone para duplicação de modelos (Silabor, Clássico Art. Odontol., Brasil) de acordo com as especificações do fabricante. A partir desses moldes, foram vazados então, vinte modelos, denominados de modelos $\mathrm{C}$, também com gesso pedra especial microgranulado (Durone, Dentsply Ind. e Com. Ltda., Brasil) para aumentar a resistência desses modelos para as etapas seguintes, e manipulado de acordo com as 
instruções do fabricante. Todos os modelos foram recortados em recortador de gesso e pesados de modo a terem o mesmo peso (80g) cada um (Figuras 4.6, 4.7 e 4.8).

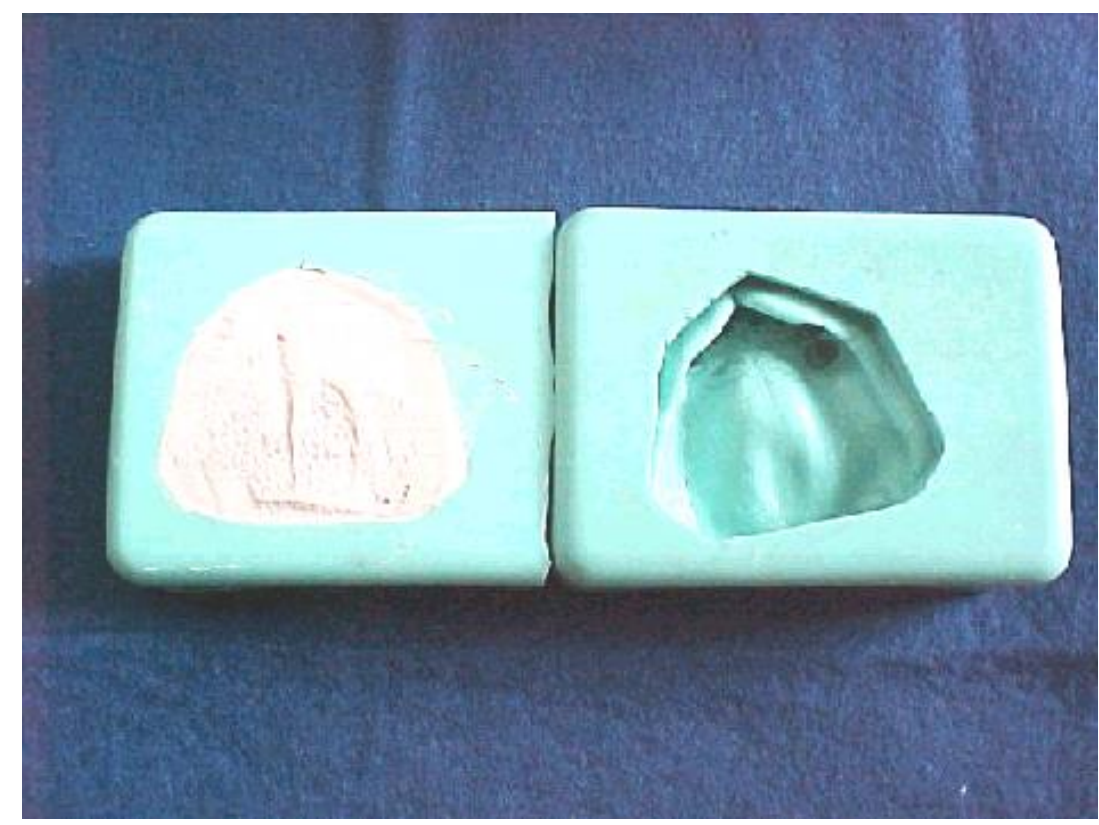

Figura 4.6 - Após a obtenção dos moldes do modelo-padrão, os modelos foram duplicados: à esquerda o molde vazado

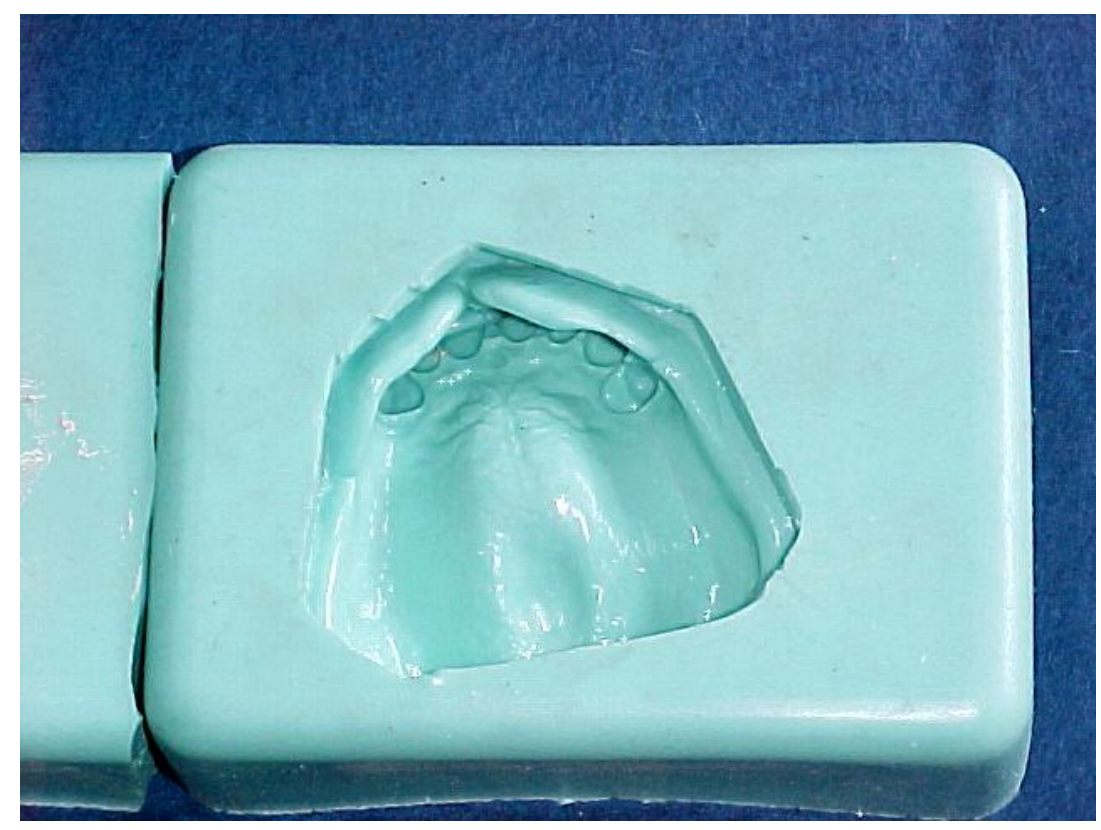

Figura 4.7 - Detalhe do molde de borracha de silicone para a duplicação dos modelos 


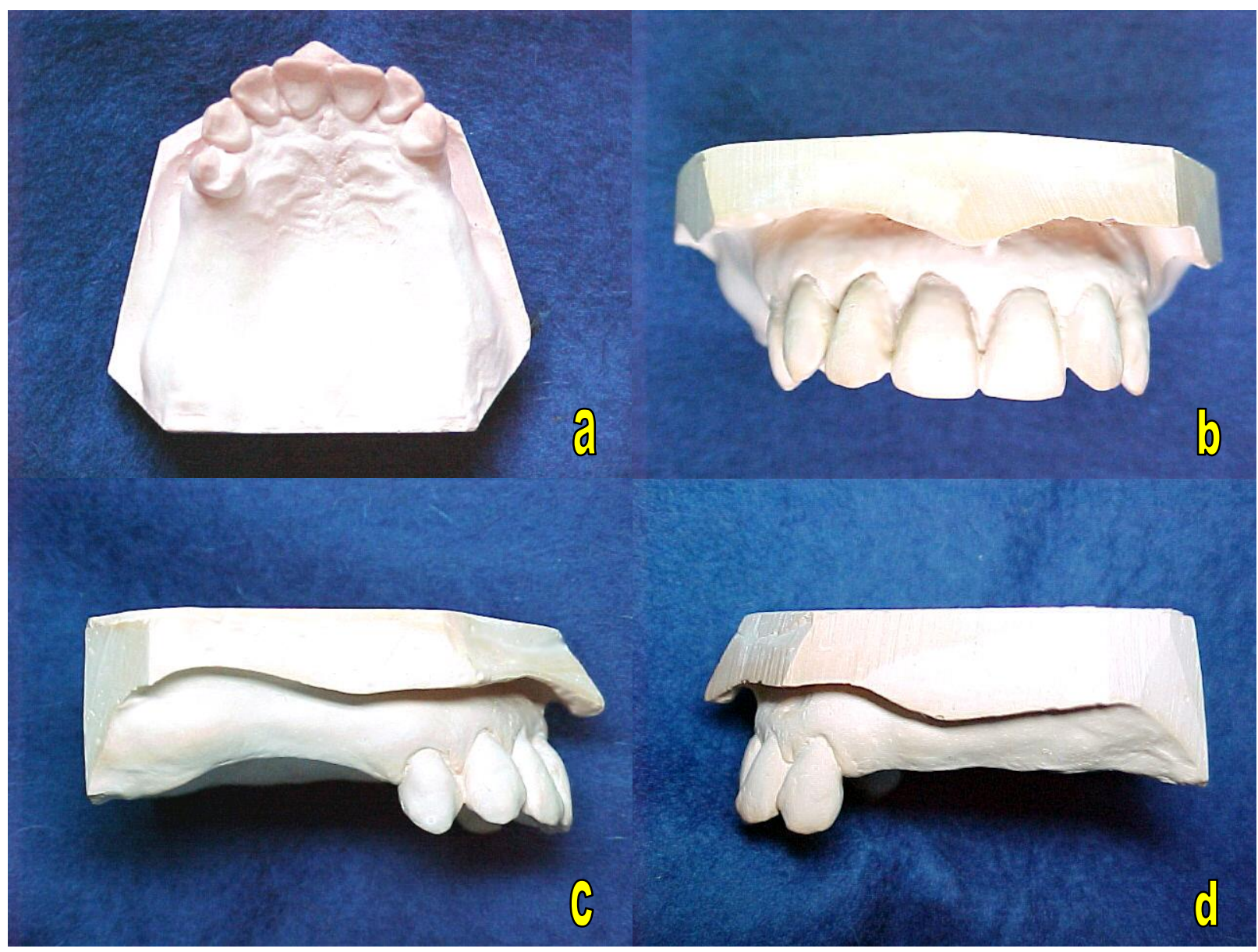

Figura 4.8 - Detalhe de um modelo de gesso C (convencional) obtido a partir do molde do modelo-padrão: (a) vista Oclusal; (b) vista anterior; $(c)$ vista do lado direito e, $(d)$ vista do lado esquerdo

Devido tratar-se de uma arcada de Classe I de Kennedy, é indicado a utilização de um plano de orientação para a montagem dos modelos de gesso nos articuladores.

Para efetivarmos a montagem desses modelos, baseamo-nos em diversos trabalhos da literatura que dão suporte científico à metodologia que foi seguida para a realização da montagem pela técnica convencional. Não tivemos nesse momento, portanto, o propósito de fazer uma nova revisão da literatura e, sim, embasar 
cientificamente todos os passos clínicos e laboratoriais necessários para esse procedimento de montagem. Os mais significativos serão citados a seguir.

Miller (1972); Henderson \& Steffel (1979) e Whitbeck \& Ivanhoe (1985) indicavam o uso de resina acrílica para a construção das bases de registro. É conveniente lembrar o trabalho de Phillips (1976) que referiu sobre a contração de polimerização dessas resinas. McCracken (1962); Miller (1972) e Desplats (1986) indicavam a utilização de cera para a confecção dos planos de orientação, para reconstruir o que seria o plano oclusal. Também vale lembrar que Henderson \& Steffel (1979) demonstraram que ao utilizar um plano de orientação, denominado pelos autores de guia oclusal, os tecidos que recobrem os rebordos residuais podem ser deslocados, quase sempre quando o paciente fecha a boca sobre a cera do plano. Assim sendo, segundo os autores, após as impressões obtidas na cera, em decorrência da pressão, o plano de orientação não iria reproduzir a dimensão vertical exata do paciente.

Osborne \& Lamie (1968); Miller (1972) e Desplats (1986) indicavam o uso de grampos provisórios aplicados nos dentes adjacentes ao espaço protético para estabilizar a base de registro em posição, evitando o possível movimento posterior das bases de Classe I de Kennedy.

De posse dos modelos padronizados, foram construídos planos de orientação, cuja descrição será feita mais adiante, para obtenção do tripodismo necessário à montagem de modelos de gesso superiores sem suportes posteriores.

Segundo Schnader (1981) e Ziebert \& Balthazar (1984) citados por Freilich et al. (1992) a presença de três pontos de apoio espaçados, um anterior e dois posteriores (um de cada lado da arcada) é o número mínimo indispensável para a montagem dos modelos. Esses autores demonstraram que os materiais mais indicados para esse fim 
são aqueles que se apresentam macios na introdução e tornam-se rígidos na remoção da boca, como ocorre com a pasta de óxido de zinco e eugenol. Esses materiais são colocados entre os dentes e entre os materiais combinados colocados nas áreas edêntulas (resina e cera) e os materiais utilizados no garfo do arco facial, como a godiva. São denominados de meios macios de transferência.

Com os modelos previamente delimitados com a área basal necessária à confecção das bases de registro, foram confeccionados grampos com fio ortodôntico de 0,6mm (Remanit, Odonto Comercial Imp. Ltda., Brasil) nos dentes adjacentes aos espaços protéticos, a fim de dar estabilidade à base de registro em resina acrílica. Esses grampos foram posicionados nas faces vestibulares dos dentes e fixados com cera rosa $\mathrm{n}^{\mathrm{o}} 7$ (Wilson, Polidental Ind. e Com Ltda., Brasil). Os modelos foram então isolados com isolante próprio para gesso (Isolit, Degussa S. A., Brasil) com auxílio de um pincel $\mathrm{n}^{\mathrm{o}}$ 18. Em seguida, a base de registro foi confeccionada em cada modelo com resina acrílica autopolimerizável incolor (Jet, Clássico Art. Odontol., Brasil). É sabido que a resina incolor promove uma transparência à base que permite verificar a presença de tensões e isquemias na hora da prova clínica. Tomou-se o cuidado de uniformizar a espessura da base em $2 \mathrm{~mm}$. A técnica utilizada foi a seguinte:

a) a resina foi manipulada num pote de vidro com tampa para resina, misturando o polímero e o monômero com uma espátula $\mathrm{n}^{\mathrm{o}} 31$ até saturar;

b) quando a resina encontrava-se na fase arenosa, foi distribuída de forma homogênea sobre a crista do rebordo alveolar e com auxílio do dedo indicador e da espátula $\mathrm{n}^{\mathrm{o}} 31$, umedecidos em monômero, foi distribuída para as vertentes vestibular e palatina, conformando assim um pouco além das áreas limítrofes;

c) com auxílio da espátula $n^{0} 31$, molhada em monômero, empurrou-se o excesso de resina do fundo de sulco vestibular em direção ao rebordo. 
d) após a polimerização da resina, as bases foram recortadas em seus bordos, respeitando-se o limite da área da base. Utilizou-se para tal a fresa de carbeto de tungstênio (H79FSQ, Komet Brasseler GmbH \& Co., Germany), pedra montada branca em forma de pêra (Jon Prod. Odontol. Ltda., Brasil) ponta montada verde ${ }^{\text {a }}$ e disco de carboneto de silício $^{\mathrm{b}}\left(4219^{\mathrm{a}}, 5177^{\mathrm{b}}, 3 \mathrm{M}\right.$ Dedeco Dental Abrasives, Co., USA) e de lixa (Moore's, E. C. Moore Co., Inc., USA);

e) após o ajuste da base na boca da paciente, como acabamento final, as arestas foram arredondadas com auxílio de tiras de lixa (média fina, 3M do Brasil Ltda.) e discos de lixa (Sof-Lex, 3M do Brasil Ltda.) e polidas com pontas de borracha (9644, Komet Brasseler GmbH \& Co., Germany), deixando as bordas arredondadas e lisas.

Com as bases de registro prontas, foram confeccionados os roletes de cera e adaptados às bases. Esses roletes de cera, segundo Freilich et al. (1992) funcionam como substitutos dos dentes ausentes para obtenção do tripodismo (estabilidade horizontal) necessário a montagem do modelo de gesso superior. Os roletes foram confeccionados com cera rosa $n^{0} 7$ (Wilson, Polidental Ind. e Com Ltda., Brasil) do seguinte modo:

a) com auxílio de uma régua milimetrada, foram feitas marcações na lâmina de cera de um em um centímetro, no sentido de seu menor comprimento, para facilitar a dobradura;

b) plastificou-se a cera sobre a chama de lamparina e, sobre uma placa de vidro, foi-se dobrando a lâmina de cera em forma de sanfona (no seu maior eixo), conformando assim um rolete de cera com cerca de $1,5 \mathrm{~mm}$ de espessura no sentido vestíbulo-palatino. Após esse procedimento o rolete foi cortado num tamanho compatível com o espaço edentado de ambos os lados da arcada; 
c) o rolete foi fixado à base de registro com auxílio das espátulas $n^{\text {os }} 7$ e 31 e lamparina de chama dirigida (Hot Shot, Blazer Corp., USA);

d) com auxílio de uma placa conformadora de plano oclusal (Jon Prod. Odontol. Ltda., Brasil) previamente isolada com vaselina sólida (Phoenix Química e Farma. Ltda., SP, Brasil) procurou-se padronizar todos os planos, da seguinte forma: após o término da construção do plano de orientação (base de registro + rolete de cera), a cera do rolete foi plastificada com a lamparina de chama dirigida (Hot Shot, Blazer Corp., USA) e em seguida, foi aplicada a placa conformada do plano de maneira que a mesma tocasse os bordos dos incisivos centrais, a ponta do primeiro premolar direito e a ponta do canino esquerdo, procedimento este que determinou o que seria o plano oclusal da paciente, que é desdentada total inferior, com uma altura posterior de $2,5 \mathrm{~cm}$ da base do modelo à superfície interna da placa conformadora (Figura 4.9).

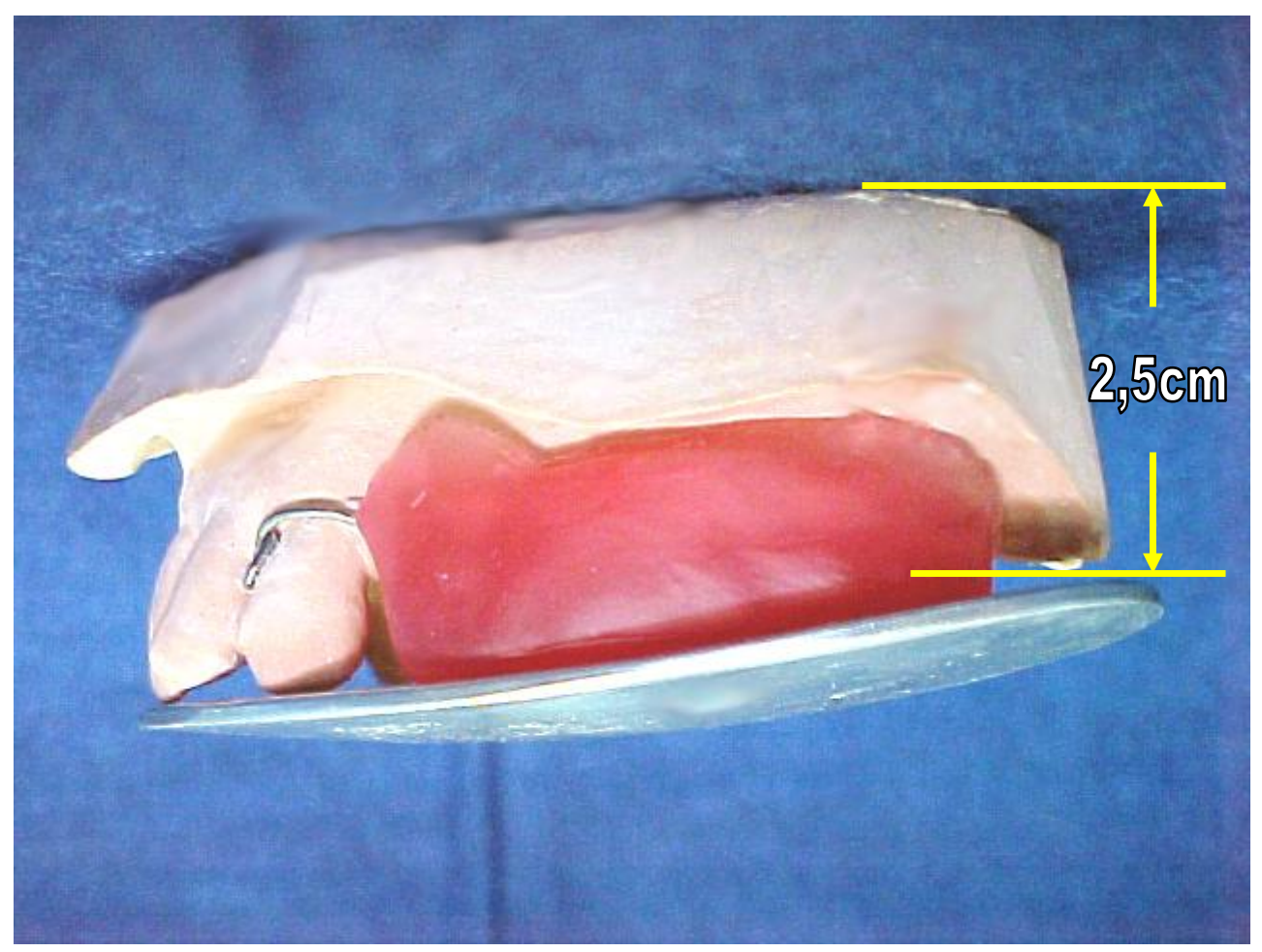

Figura 4.9 - Plano de orientação com a curva antero-posterior confeccionada previamente pela placa conformadora de plano oclusal e, com uma altura posterior de $2,5 \mathrm{~cm}$ da base do modelo à superfície interna da placa 
Os planos de orientação assim padronizados foram entregues aos operadores para utilização na técnica convencional juntamente com os modelos de gesso padronizados.

\subsubsection{Metodologia para o ajuste do arco facial e montagem no articulador com a técnica convencional}

Foram realizadas por esse método vinte montagens convencionais numeradas de C01 a C20, nos respectivos articuladores numerados de 1 a 20, sendo oportuno lembrar que no articulador 01 foi executada uma montagem de demonstração (C01) que serviu de controle. As dezenove restantes foram executadas pelos 10 profissionais (operadores) convidados.

Para o registro do arco facial e montagem dos modelos no articulador, cada operador seguiu um protocolo de acordo com a técnica preconizada por Teteruck \& Lundeen (1966); Hickey et al. (1967); Parel (1972); Whitsett et al. (1977); Laing \& Wise (1978); Henderson \& Steffel (1979); Kotwal (1979); Hockel (1980); Wise (1982); Shillingburg et al. (1983); Carter (1984); Zuckerman (1985); Malone \& Koth (1991); Mohl et al. (1991); Ellis III et al. (1992); Todescan et al. (1998) e pelo manual de instruções do articulador Whip Mix 8500, a qual será descrita a seguir:

1 - inicialmente, para uma melhor adaptação da base de registro em resina acrílica do plano de orientação na fibromucosa da área desdentada, o modelo de gesso foi isolado nessa região com vaselina sólida (Phoenix Química e Farma. Ltda., SP, Brasil) e uma porção de pasta de óxido de zinco e eugenol (Lysanda Prod. Odontol. Ltda., Brasil) foi espatulada e colocada na parte interna da base e, assim, recolocada no modelo de 
gesso (Figura 4.10). Beckett (1955); Swenson \& Terkla (1958); Terkla \& Laney (1963) e Rudd et al. (1981) indicavam o reembasamento da base de registro com pasta de óxido de zinco e eugenol sobre o modelo de gesso, denominada de base estabilizada, para obter um melhor assentamento da base sobre a fibromucosa e com a finalidade de minimizar o deslocamento dos tecidos moles que servem de suporte para a base.

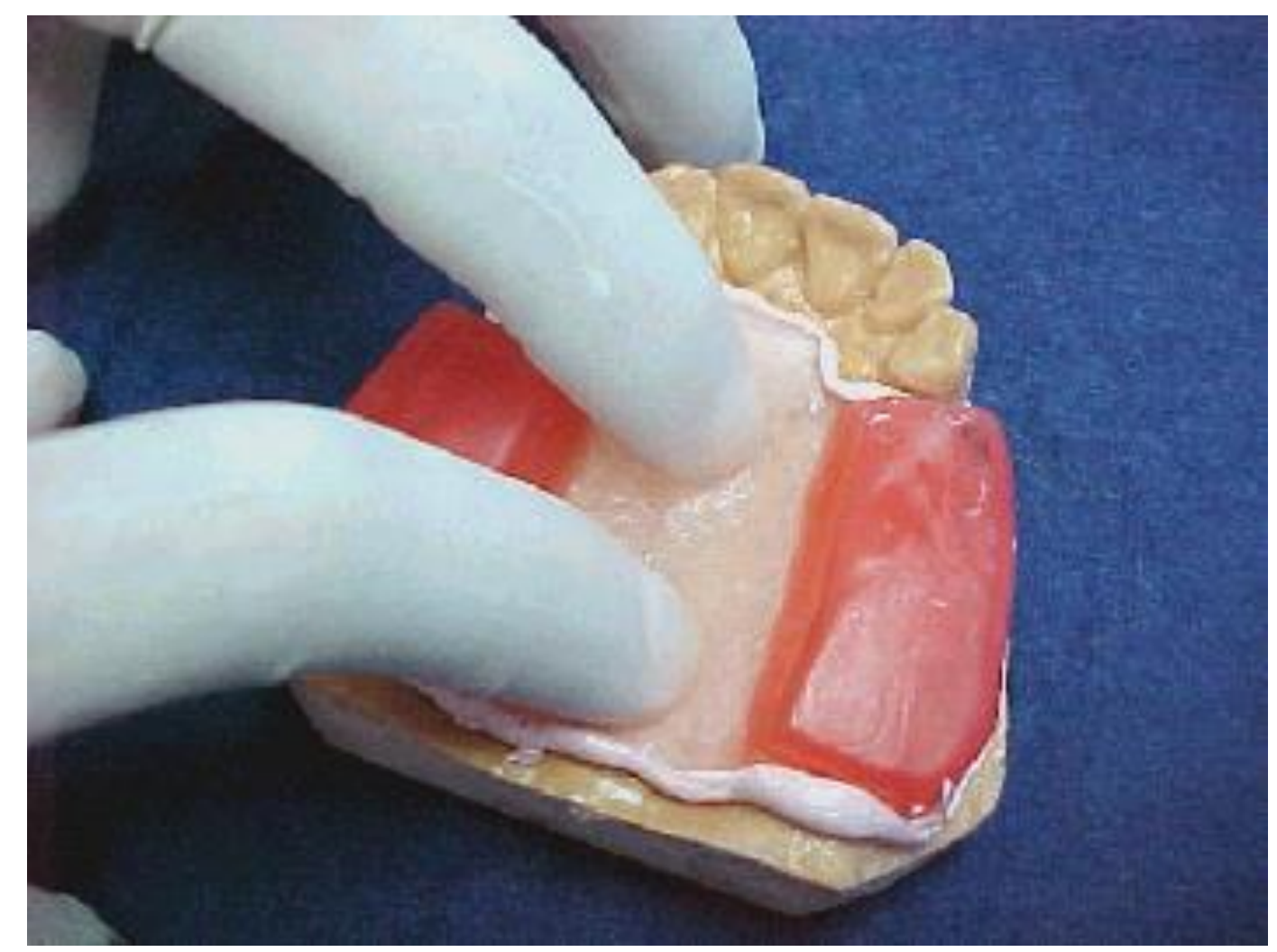

Figura 4.10 - Melhoria da adaptação do plano de orientação no modelo com a aplicação de pasta de óxido de zinco e eugenol (base estabilizada)

Os excessos da pasta foram removidos com uma lâmina de bisturi e, dessa maneira, o plano de orientação (rolete de cera) foi vaselinado e colocado na boca da paciente (Figura 4.11).

2 - para o registro das pontas de cúspides no garfo de mordida do arco facial, bem como do rolete de cera do plano de orientação, foi utilizado, como meio macio ou 
veículo de transferência, um material de moldagem termoplástico (godiva) de média fusão e de baixo escoamento (Godibar, Lysanda Prod. Odontol Ltda., Brasil) que foi plastificado em água a $55^{\circ} \mathrm{C}$ num plastificador elétrico (Plastificador de godiva, MariJós Ind. e Com., PR, Brasil) e adaptado ao garfo de mordida de modo uniforme.

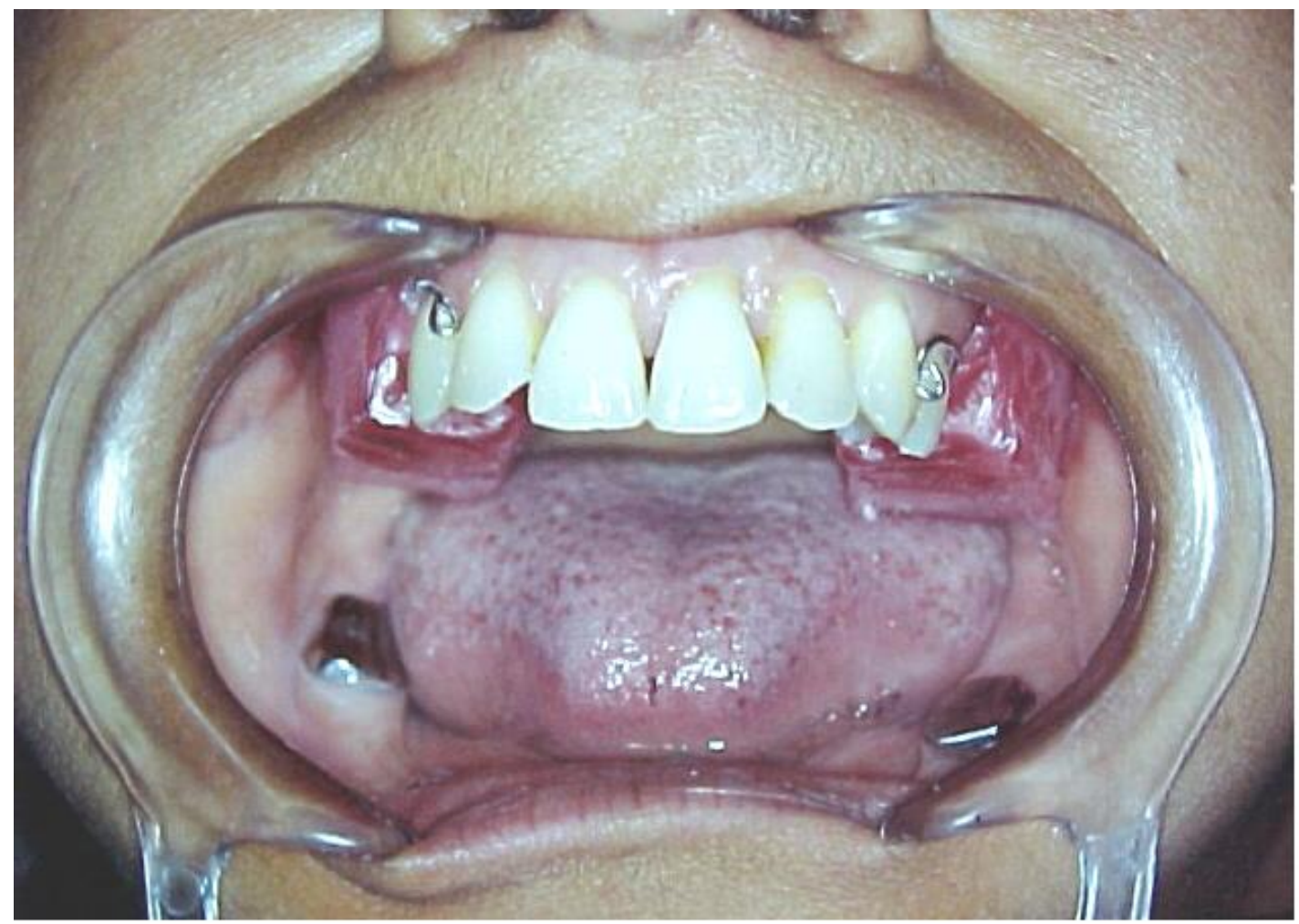

Figura 4.11 - Plano de orientação recolocado na boca da paciente

3 - o garfo de mordida foi então colocado na boca da paciente, tomando-se o cuidado de centralizar seu cabo em relação ao plano mediano e, assim, uma pequena e uniforme pressão foi feita no garfo, contra os dentes superiores e o plano de 
orientação, de modo a obter somente a impressão das pontas de cúspides (edentação) e da cera do plano. Um cuidado especial foi tomado para não deixar as pontas de cúspides penetrarem muito na godiva de modo a não tocarem no metal do garfo, bem como, não produzir uma deformação da cera do plano de orientação para baixo do plano de oclusão dos dentes remanescentes. Após esse procedimento, a godiva foi resfriada com jato de água e depois removida da boca. Todo o excesso de godiva, das ameias e das áreas de tecidos moles impressas, foram cortados e removidos. A vaselina sólida do rolete de cera foi também removida.

4 - com o intuito de controlar melhor a resiliência da fibromucosa, o plano de orientação foi plastificado no plastificador elétrico em $55^{\circ} \mathrm{C}$ (Plastificador de godiva, Mari-Jós Ind. e Com., PR, Brasil) e recolocado na boca e, para aumentar a precisão do registro do garfo do arco facial, foi utilizada a pasta de óxido de zinco e eugenol de alto escoamento (Lysanda Prod. Odontol. Ltda., Brasil), colocada somente nas impressões de cúspides e na região da impressão do plano de orientação e, assim, o garfo de mordida foi recolocado na boca com uma leve pressão (Figura 4.12).

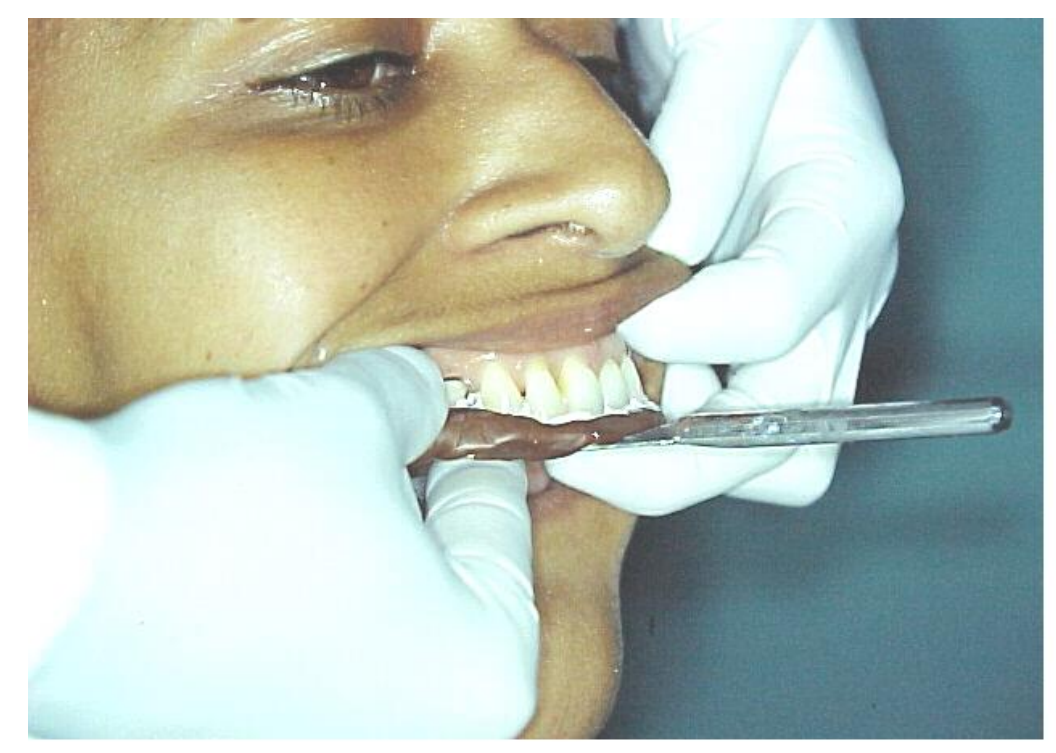

Figura 4.12 - Colocação do garfo com godiva e pasta de óxido de zinco e eugenol, para o registro da posição da arcada superior da paciente 
Osborne \& Lamie (1968); Henderson \& Steffel (1979) e Whitbeck \& Ivanhoe (1985) indicavam o uso de pasta de óxido de zinco e eugenol para o registro oclusal, para evitar a compressão da fibromucosa. Machado (1992) concluiu em seu trabalho, que a utilização desses materiais constitui um recurso aceitável de confecção e estabilização das bases de registro.

5 - com o auxílio de uma assistente, o garfo foi mantido em posição na boca da paciente para o posicionamento e ajustes do arco facial.

Esse tipo de arco facial arbitrário simples provém do desenho original do articulador Whip Mix modelo 8500 (Whip Mix Corp., USA), desenvolvido pelo Dr. Charles Stuart em 1963 e descrito por Hickey et al., 1967. Foi concebido para utilizar os meatos acústicos externos (pontos posteriores) como meio de se obter a localização arbitrária do eixo terminal de rotação dos côndilos da mandíbula, e um suporte nasal (ponto anterior) para obtenção do plano de referência horizontal.

$\mathrm{O}$ arco foi posicionado primeiramente orientando a união universal para seu encaixe no garfo, deslizando-a pelo cabo do garfo até ficar perto dos lábios, porém sem tocá-los e permitindo que essa conexão fique completamente livre de tensão (Figura 4.13). O paciente normalmente é instruído para auxiliar na colocação das olivas do arco simultaneamente nos meatos acústicos externos de ambos os lados, tal como o faria com um estetoscópio. Os três parafusos superiores do arco foram apertados para manter esta posição (Figura 4.14). 


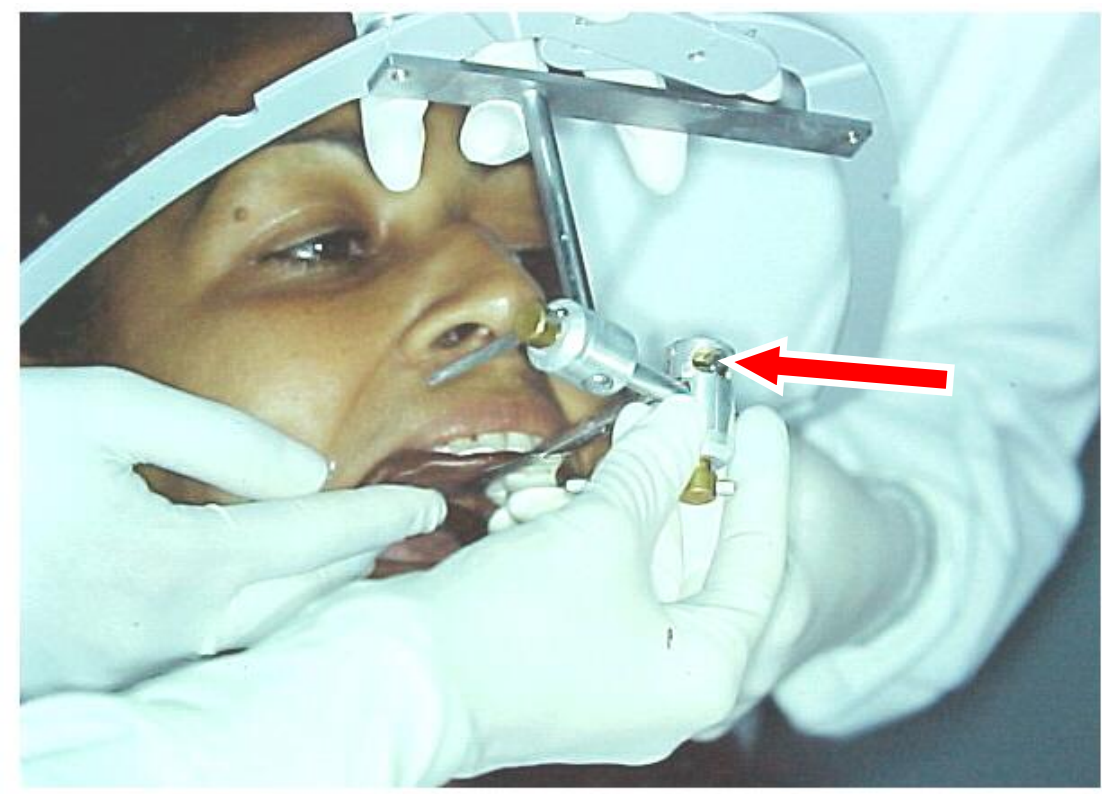

Figura 4.13 - Colocação do arco facial iniciando pela introdução da união universal no cabo do garfo (seta)

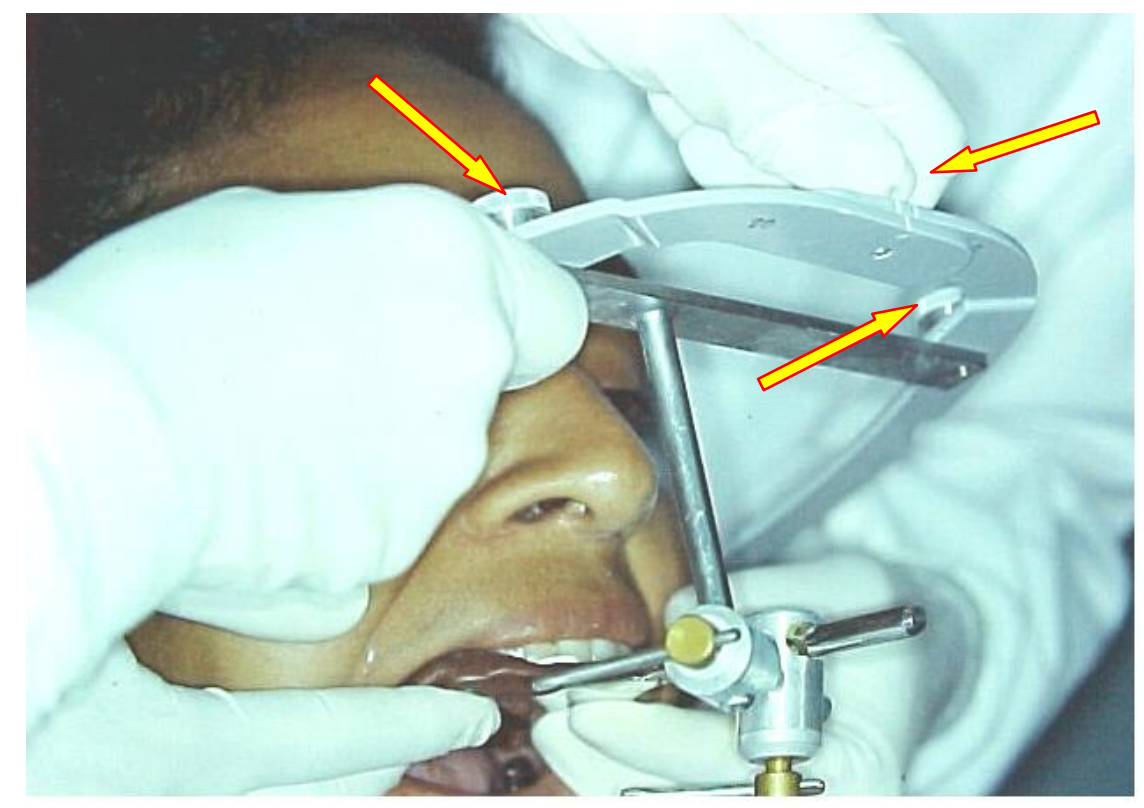

Figura 4.14 - Aperto dos três parafusos superiores do arco facial (setas) 
6 - o arco facial, então, foi ajustado anteriormente por meio do suporte nasal, relator nasal ou násion (Figura 4.15,a) como também é conhecido, de maneira a completar o terceiro ponto do plano de referência ou plano de Frankfurt, por meio de seu suporte próprio fixado na trave do arco, também denominada de suporte geral ou barra transversal do arco (Figura 4.15, b).

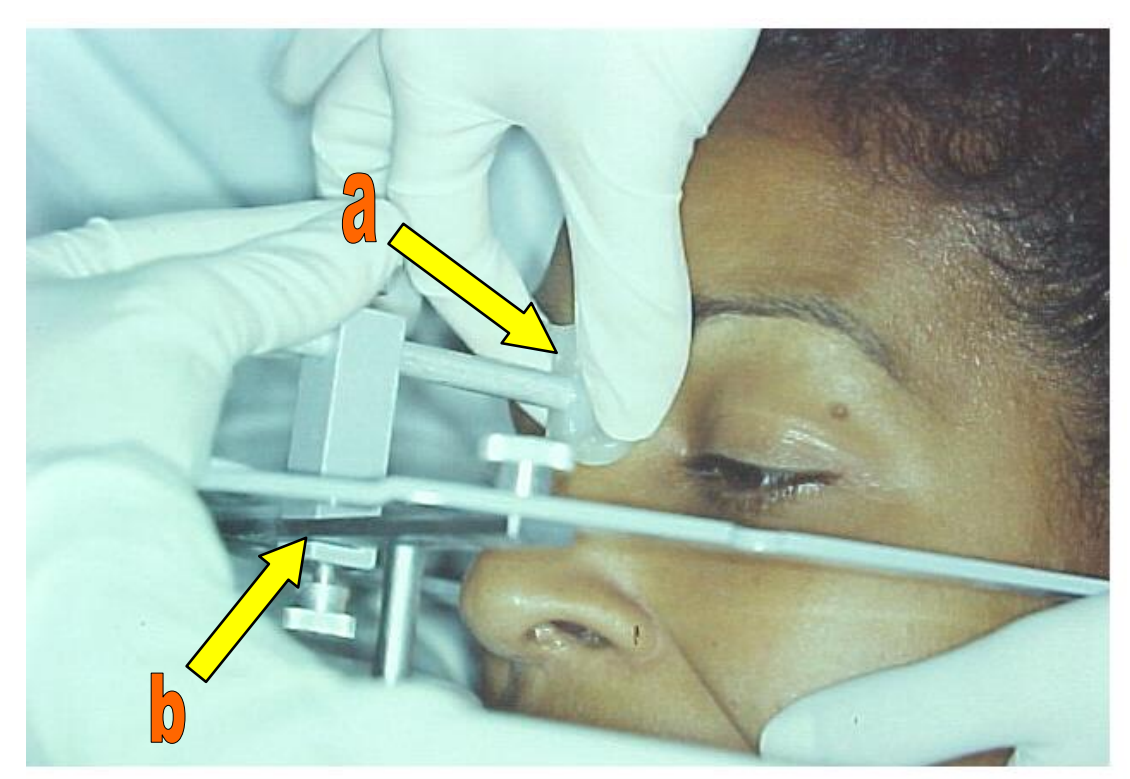

Figura 4.15 - Colocação do násion (a) no suporte geral do arco facial (b)

7 - todo o cuidado foi tomado para que, durante os procedimentos de fixação dos parafusos do arco facial, o mesmo não se desviasse de sua posição correta devido ao efeito de torção, mantendo a mão esquerda segurando firmemente o arco e deixando a outra (direita) para o aperto dos parafusos. Dessa maneira o parafuso da união universal da haste ou eixo principal horizontal foi apertado (Figura 4.16). 


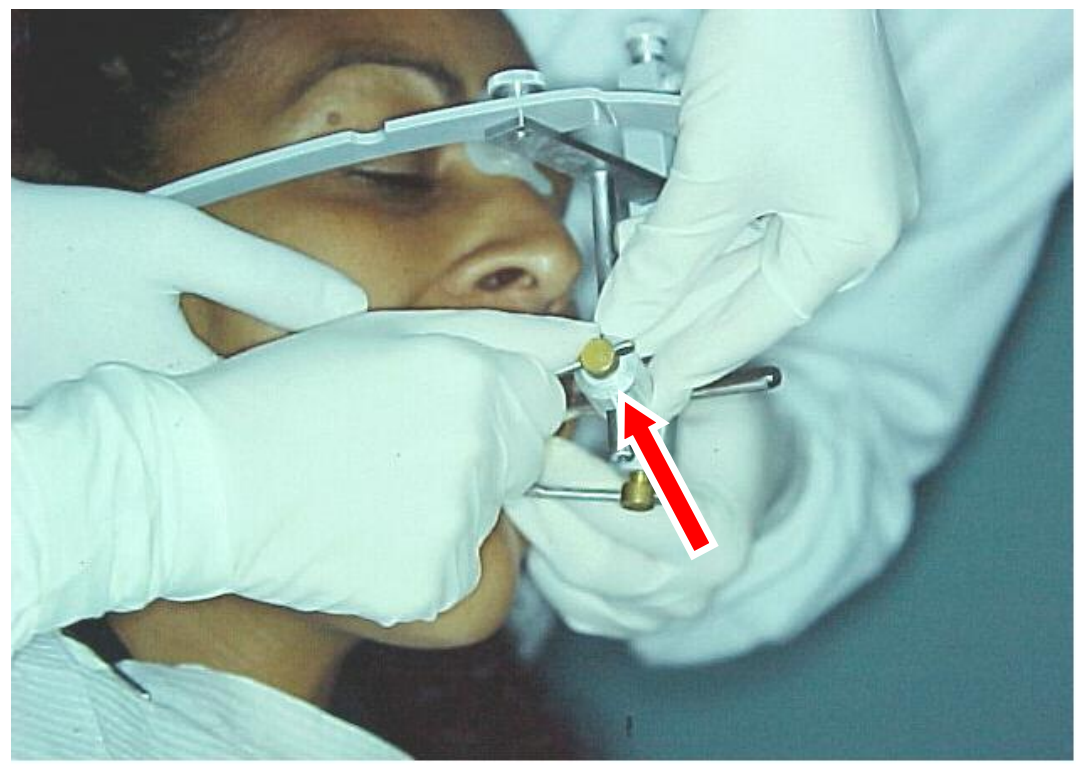

Figura 4.16 - Aperto da união universal do eixo principal do arco facial (seta)

8 - a seguir, o parafuso que aperta a união universal que fixa o garfo na posição em que se encontra na boca foi apertado firmemente (Figura 4.17).

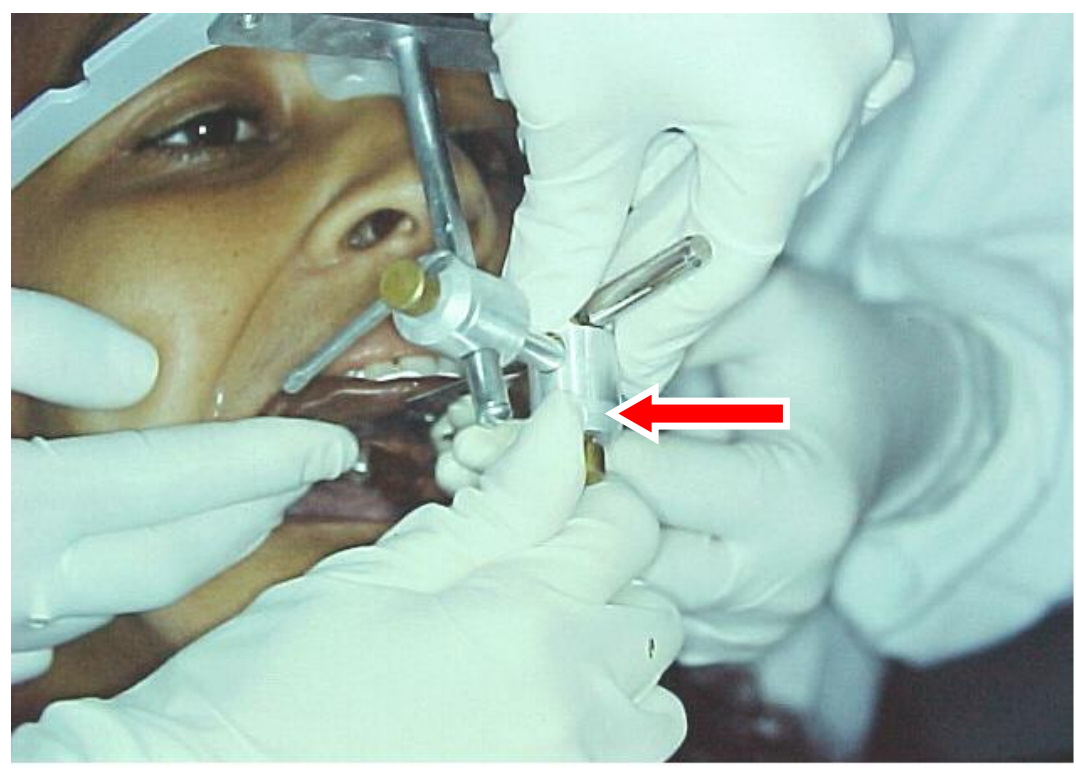

Figura 4.17 - Aperto da união universal que fixa o cabo do garfo ao arco facial (seta) 
Nessa etapa, a distância intercondilar da paciente foi anotada, para posterior ajuste dos postes condilares do articulador.

9 - após o término de todos os ajustes necessários, foi retirado o suporte nasal e afrouxados os três parafusos da parte superior do arco. Ao mesmo tempo em que a paciente foi abrindo lentamente a boca, o arco facial foi cuidadosamente removido e colocado sobre a mesa de trabalho com o garfo de mordida para cima. Nessa fase foi colocada a banda elástica ao redor do arco facial, com a finalidade de auxiliar nos procedimentos de montagem seguintes (Figura 4.18).

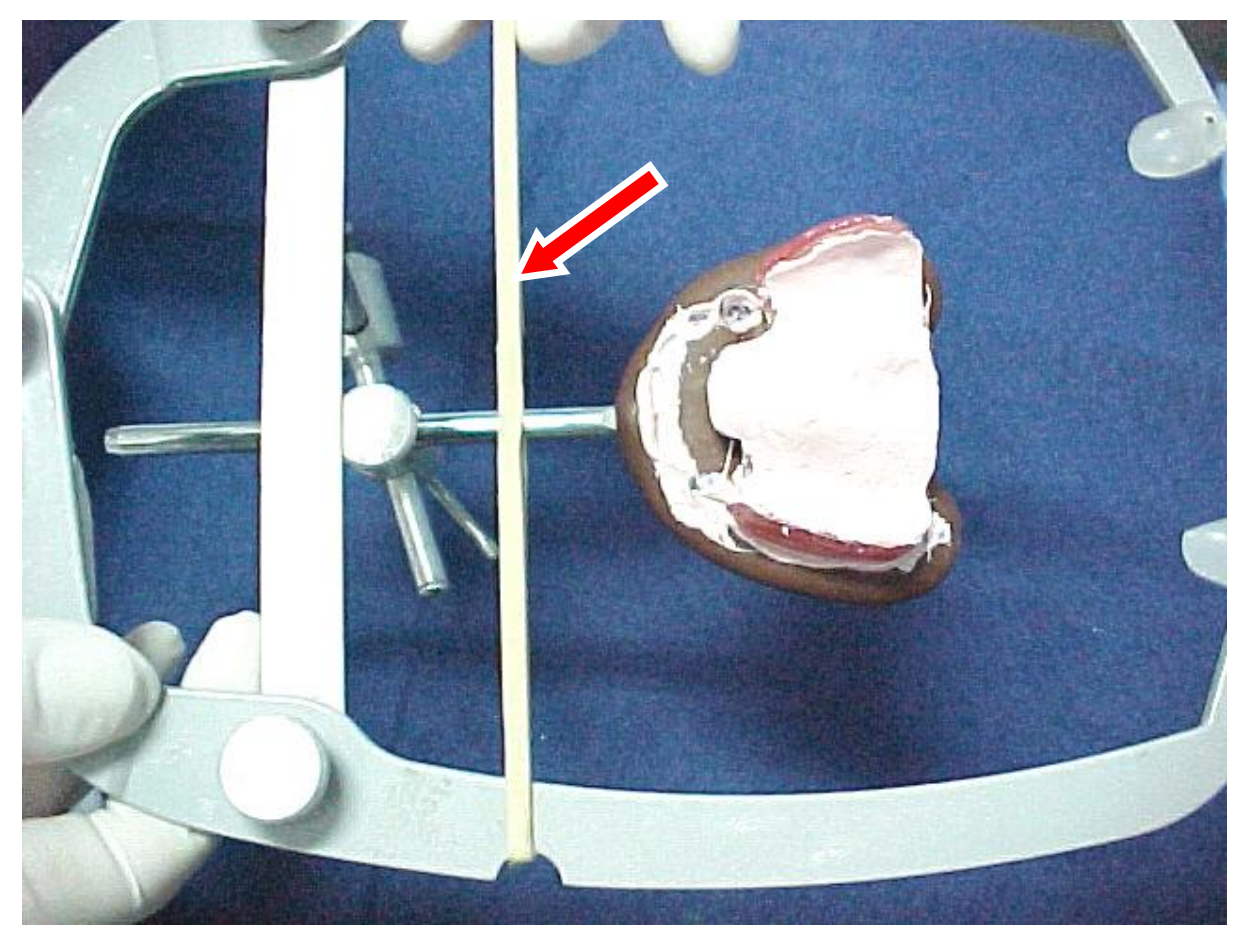

Figura 4.18 - Após a remoção do arco facial da face da paciente, deve-se colocar a banda elástica ao redor do arco (seta) 
10 - o articulador foi, então, preparado para receber o arco facial. Os elementos condilares do ramo inferior do articulador foram aparafusados nos orifícios correspondentes à distância intercondilar obtida da paciente (M, média). Estabeleceuse a mesma distância intercondilar no ramo superior, acrescentando-se um espaçador nas hastes das guias condilares, de modo a corresponder ao tamanho $\mathrm{M}$ (médio) da paciente.

11 - as guias condilares foram ajustadas numa angulação média de $30^{\circ}$, antes da colocação do arco facial, para que os pinos de fixação das olivas do arco facial, localizados nas laterais dessas guias, fiquem no mesmo plano horizontal que passa pelo centro da esfera do elemento condilar (Figuras 4.19 e 4.20).

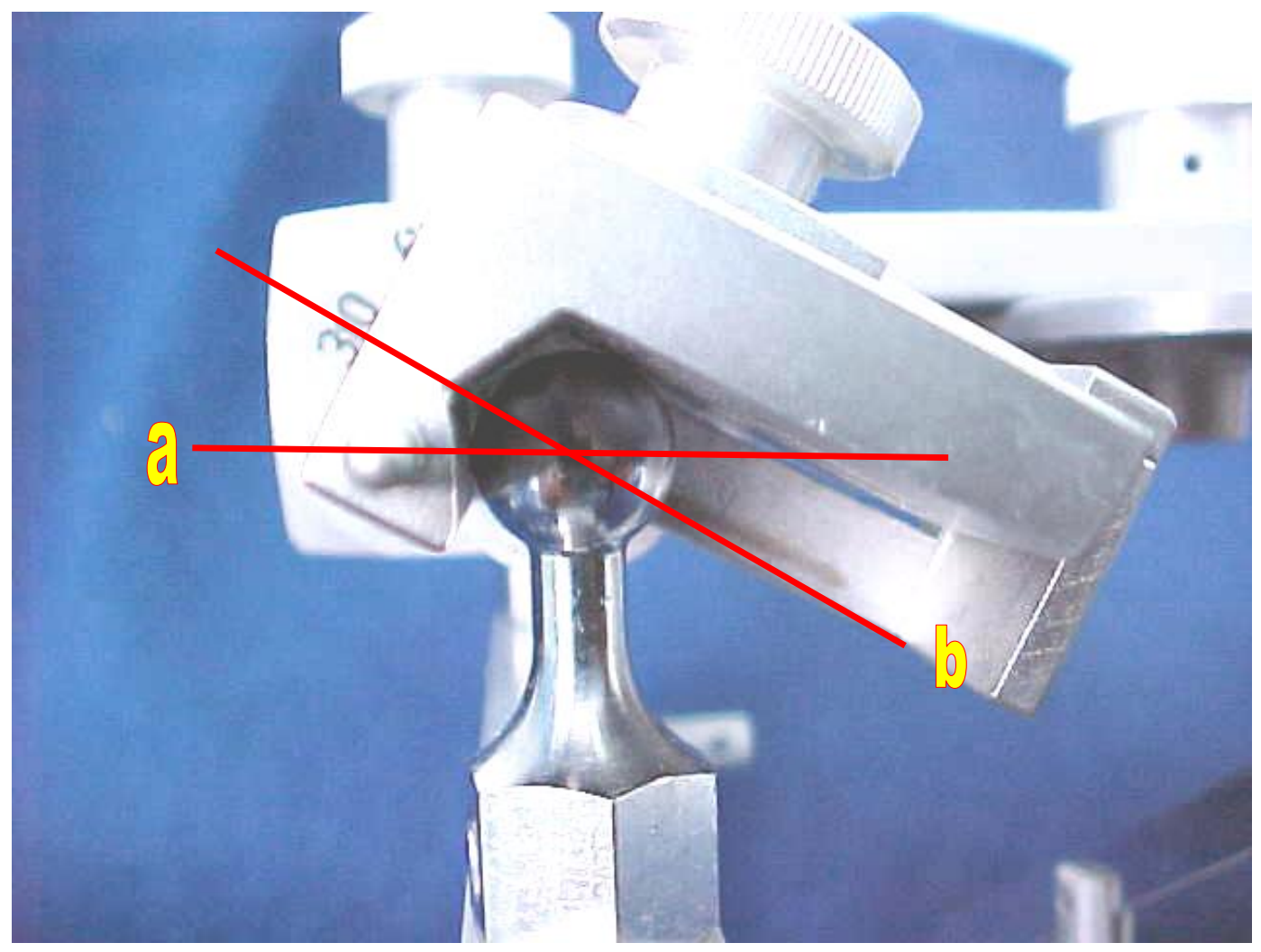

Figura 4.19 - Para que o arco facial passe pelo centro de rotação dos elementos condilares (linha a) e, dessa forma, fique paralelo ao ramo superior do articulador (plano de Frankfurt), as guias condilares devem ser ajustadas inicialmente em $30^{\circ}$ (linha $b$ ) 


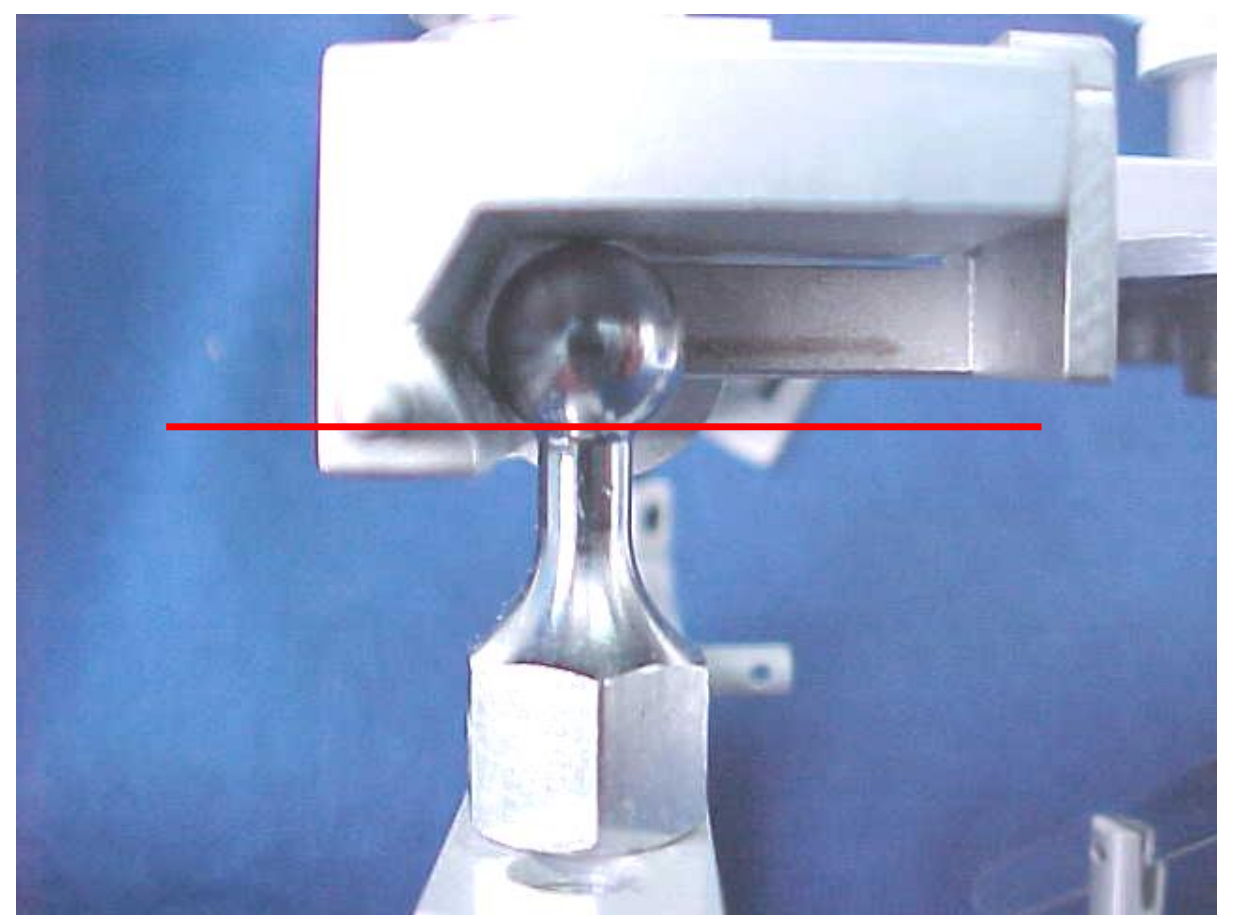

Figura 4.20 - Guia condilar regulada em $0^{\circ}$. Observar que o arco facial montado dessa forma não passaria pelo centro de rotação do elemento condilar (linha) e também não permitiria seu paralelismo com o ramo superior do articulador

12 - a placa de montagem do ramo superior foi firmemente fixada em seu local próprio. No lugar da placa de montagem inferior, foi colocado o suporte inferior do garfo, cuja função é sustentar o garfo (forquilha) do arco facial e o modelo durante os procedimentos de montagem (Figura 4.21). 


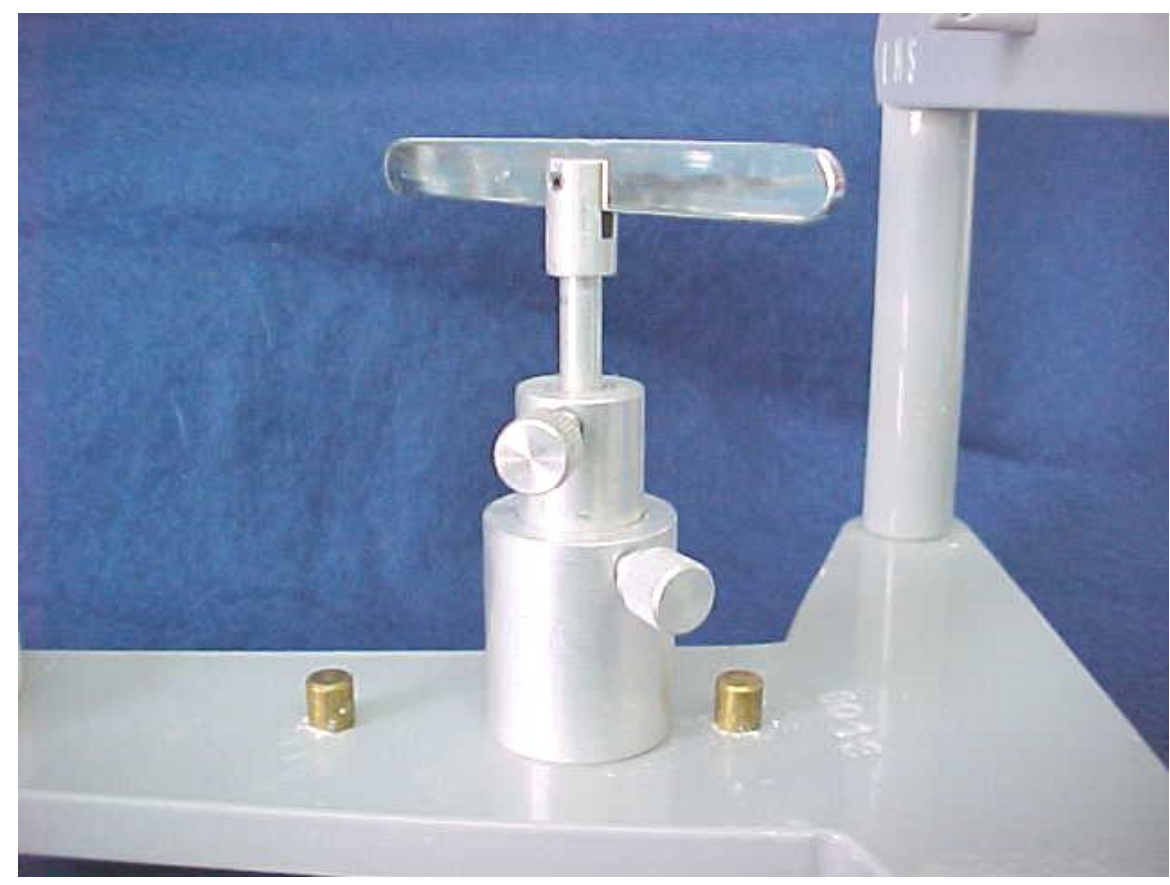

Figura 4.21 - Suporte inferior do garfo posicionado no ramo inferior do articulador

Com esse dispositivo, o peso do modelo em gesso é suportado separadamente do arco facial, eliminando, assim, a possibilidade de um movimento para baixo, conseqüente da combinação do seu peso com o do gesso utilizado para fixação do modelo. Seu uso é altamente recomendado segundo Henderson \& Steffel (1979); Costa (1998) e Costa et al. (1999).

13 - embora os autores consultados não tenham feito menção, ou mesmo relatado a aparente irrelevância do ajuste da guia do movimento lateral (ângulo de Bennett) nessa fase da montagem, procedimento esse também omitido no manual do articulador Whip Mix 8500, o ajuste dessa guia com uma angulação negativa é de 
grande valia para travar as guias condilares e, por conseqüência, o ramo superior do articulador em posição, evitando seu deslocamento posterior durante a colocação do gesso para a fixação do modelo de gesso superior (Figura 4.22).

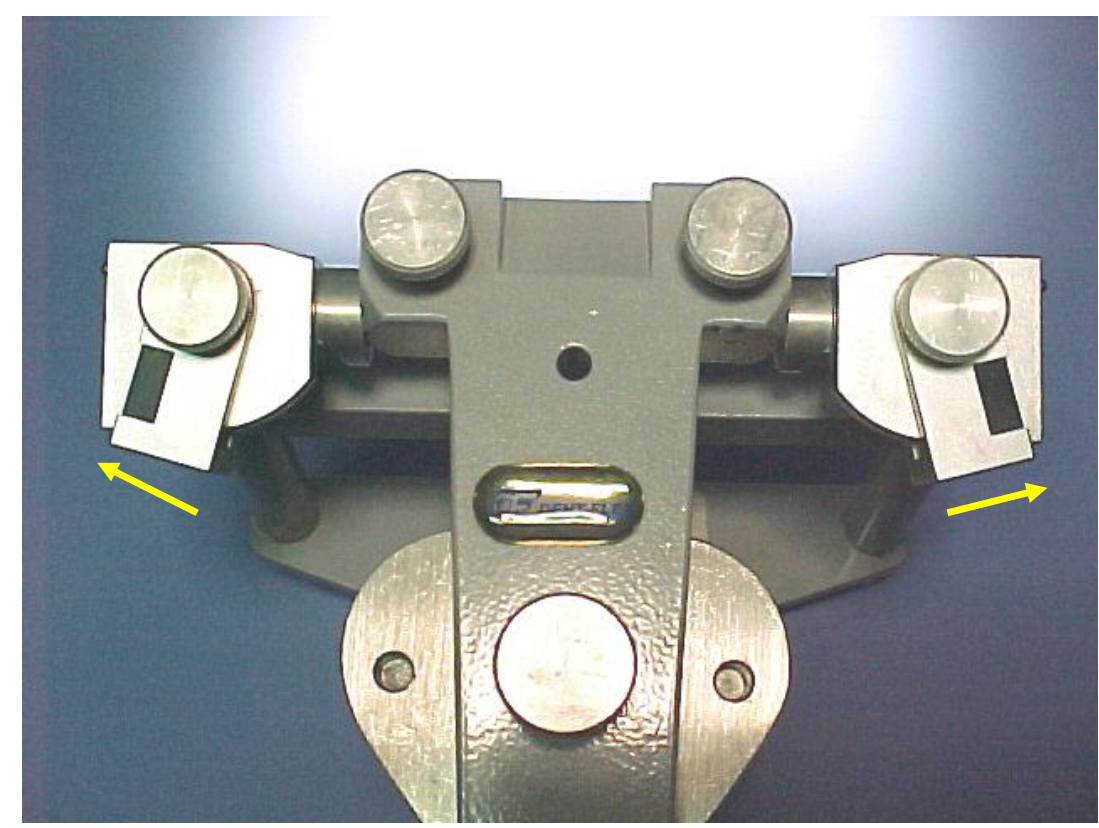

Figura 4.22 - Ajuste das guias do movimento lateral (Bennett) com angulação negativa para facilitar o manuseio do ramo superior do articulador (setas)

14 - em seguida, o arco facial foi posicionado no ramo superior do articulador por meio da fixação dos orifícios de montagem das olivas de plástico nos pinos situados externamente às guias condilares, apertando-se firmemente os três parafusos da parte superior do arco facial.

Consta do manual de instruções do articulador Whip Mix 8500, uma observação informando que "a relação entre o ramo superior do articulador e seu arco facial com o ramo inferior do mesmo e seus elementos condilares não tem 
importância nessa etapa da montagem, pois o ramo inferior serve meramente como um conveniente meio de suporte durante a montagem do modelo superior".

No entanto, foi demonstrado por Costa (1998) e Costa et al. (1999) que o arco facial, juntamente com o modelo de gesso, não pode ser apoiado sobre a mesa incisal do ramo inferior do articulador, por causa do efeito de alavanca que é gerado por esse procedimento, fazendo com que o modelo seja desposicionado em relação ao eixo de rotação da mandíbula.

15 - para evitar esse problema, é altamente indicado o uso de um suporte anterior do arco facial (conjunto de suportes Ribas, Dent-Flex Ind.. e Com. Ltda., Brasil) desenvolvido pelo autor, que elimina a possibilidade do modelo alterar sua posição no articulador, o que acarretaria todos os problemas oclusais já mencionados anteriormente. Esse suporte foi então instalado e ajustado em altura (Figura 4.23, a). 16 - o modelo foi, então, umidificado e retenções em sua base foram realizadas a fim de melhorar sua conexão ao gesso de fixação. Na seqüência o modelo foi posicionado no garfo do arco facial, com a orientação da base de registro e rolete de cera (plano de orientação) e mantido nessa posição por meio de pequenas gotas de cera rosa $n^{0} 7$ (Wilson, Polidental Ind. e Com. Ltda., Brasil) colocadas entre os dentes, plano de orientação e da godiva do garfo do arco facial. Nessa fase ajustou-se a altura do suporte inferior do garfo do arco facial, de modo a tocar levemente o garfo na parte inferior do mesmo (Figura 4.23, $b$ ). 


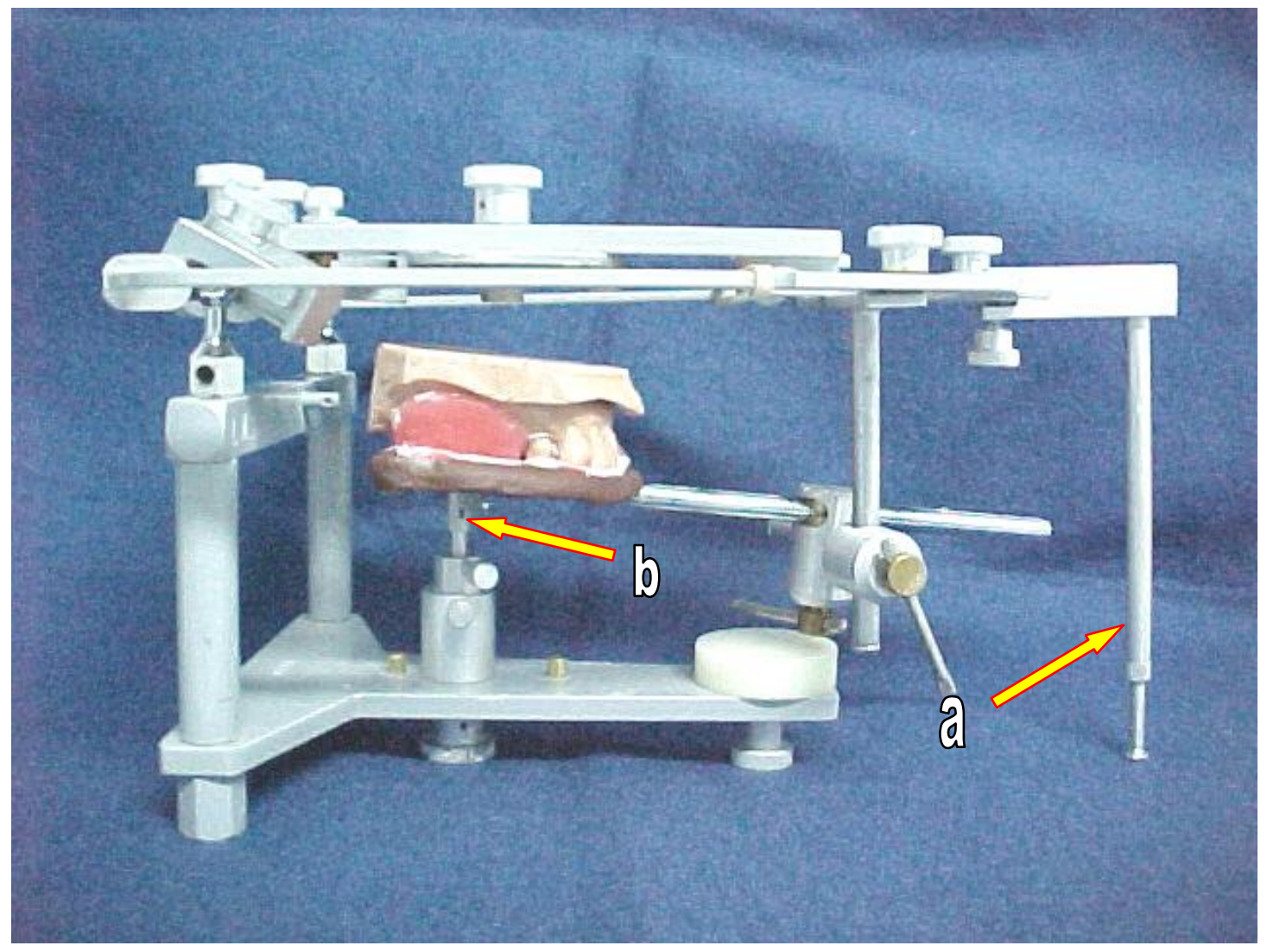

Figura 4.23- Colocação do modelo de gesso no garfo do arco facial. A seta a mostra o suporte anterior ; A seta $b$ mostra 0 suporte inferior do garfo

17 - por meio de uma porção de gesso pedra comum (Herodent, Vigodent Ind. e Com. Ltda., Brasil) o modelo foi fixado à placa de montagem do ramo superior do articulador. Seguiu-se as orientações de manipulação do gesso fornecidas pelo fabricante (100 partes de gesso para 30 de água, à temperatura ambiente). Primeiramente colocou-se uma porção de gesso na placa de montagem (Figura 4.24) e depois no modelo de gesso (Figuras 4.25 e 4.26) para não permitir uma aceleração de cristalização do gesso se colocado primeiramente sobre o modelo e, na seqüência, abaixou-se o ramo superior apoiando-o sobre o suporte geral do arco facial, tomandose o cuidado de posicionar a banda elástica sobre o ramo superior. A banda elástica irá controlar e direcionar a expansão de cristalização do gesso lateralmente (Figura 4.27). 


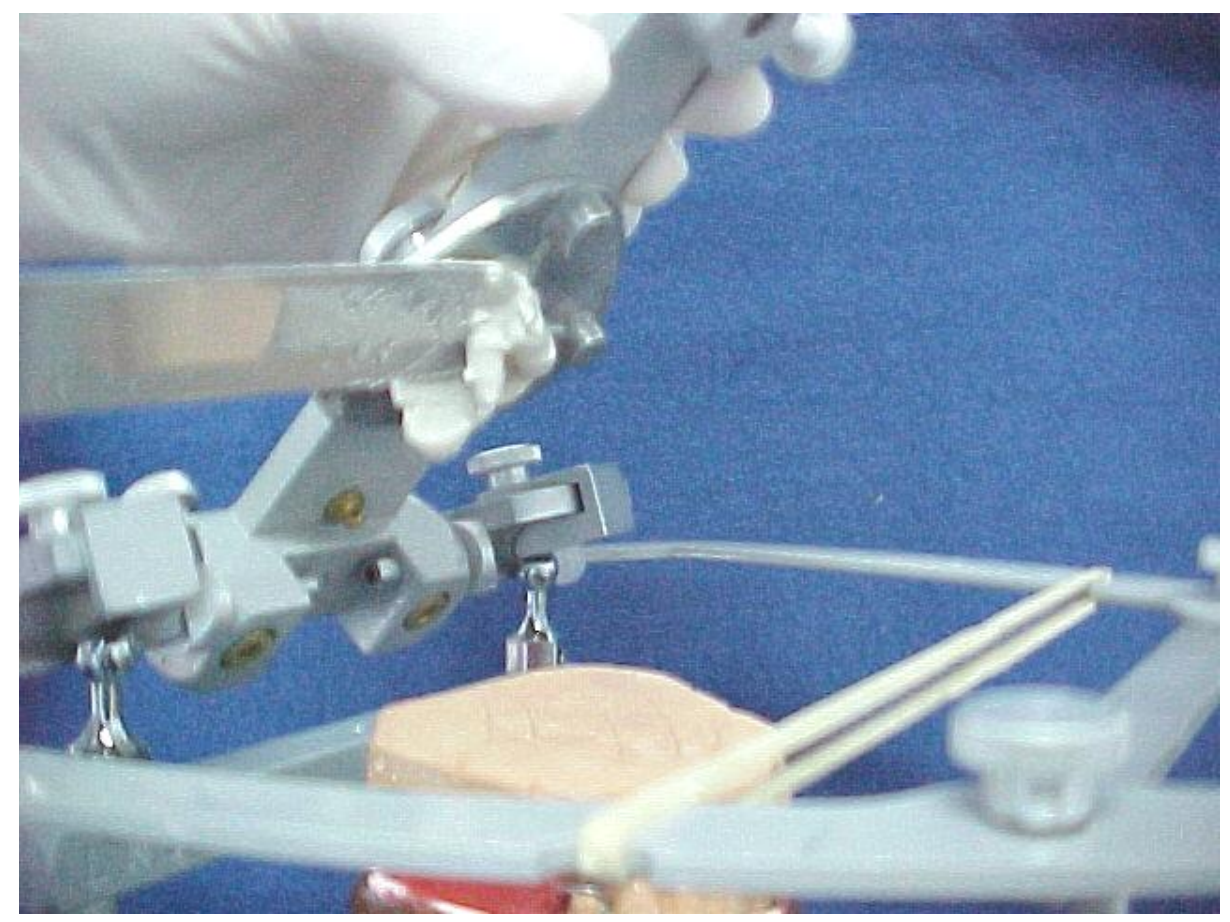

Figura 4.24 - Colocação do gesso primeiramente na placa de montagem superior

De acordo com os trabalhos de Grant (1963); Roraff \& Stansbury (1972); Dilts et al. (1978) e Peregrina \& Feil (1994) foi utilizada uma quantidade mínima de gesso suficiente para permitir a complementação da transferência do modelo ao articulador, minimizando a possibilidade de expansão de presa do gesso, que alteraria a posição do modelo de gesso (Figuras 4.28 e 4.29).

18 - após a cristalização do gesso, uma nova camada foi aplicada para aumentar a resistência de fixação do modelo ao articulador (Figura 4.30). 


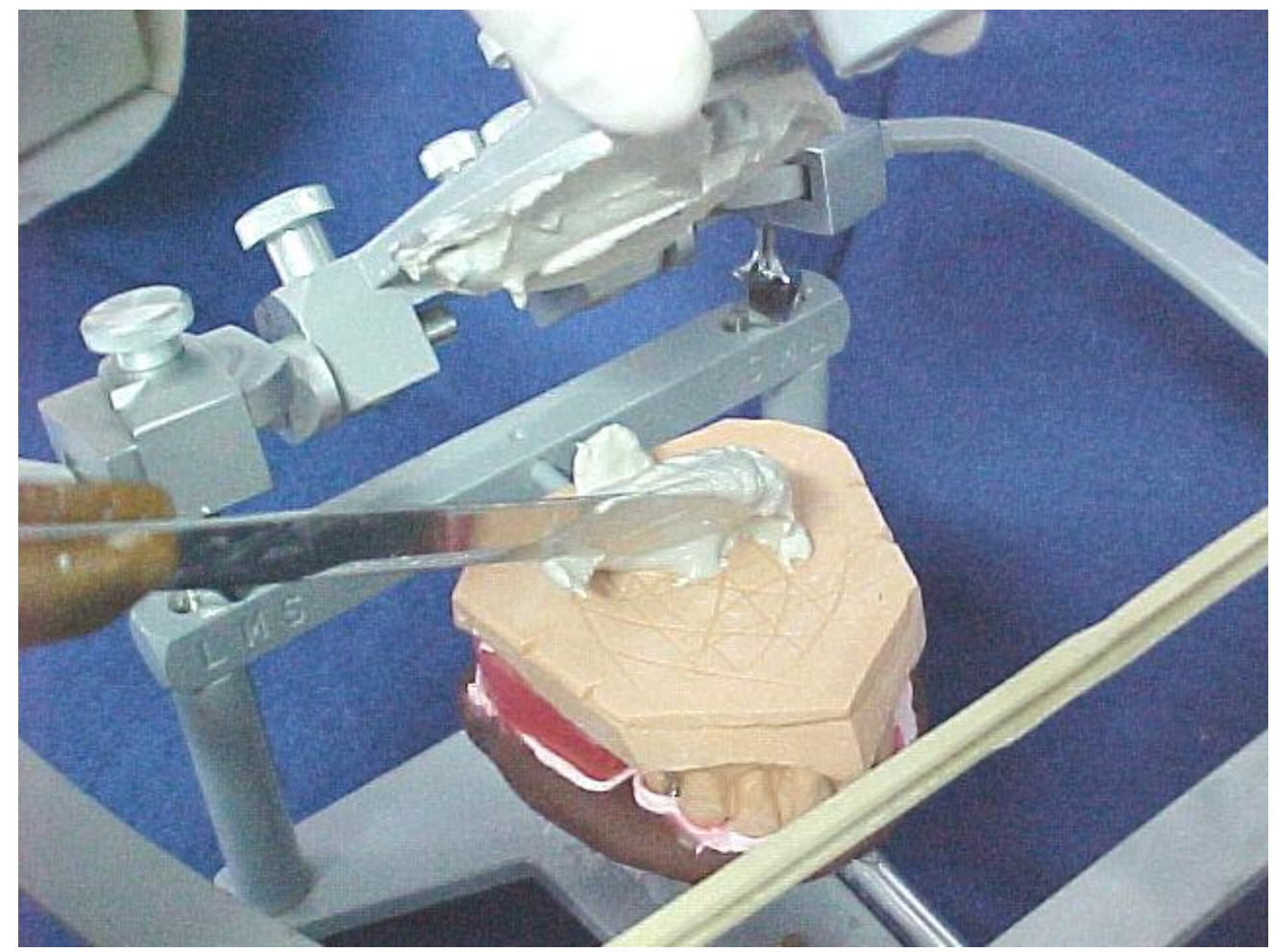

Figura 4.25 - 0 gesso é colocado na base do modelo após a placa superior do articulador

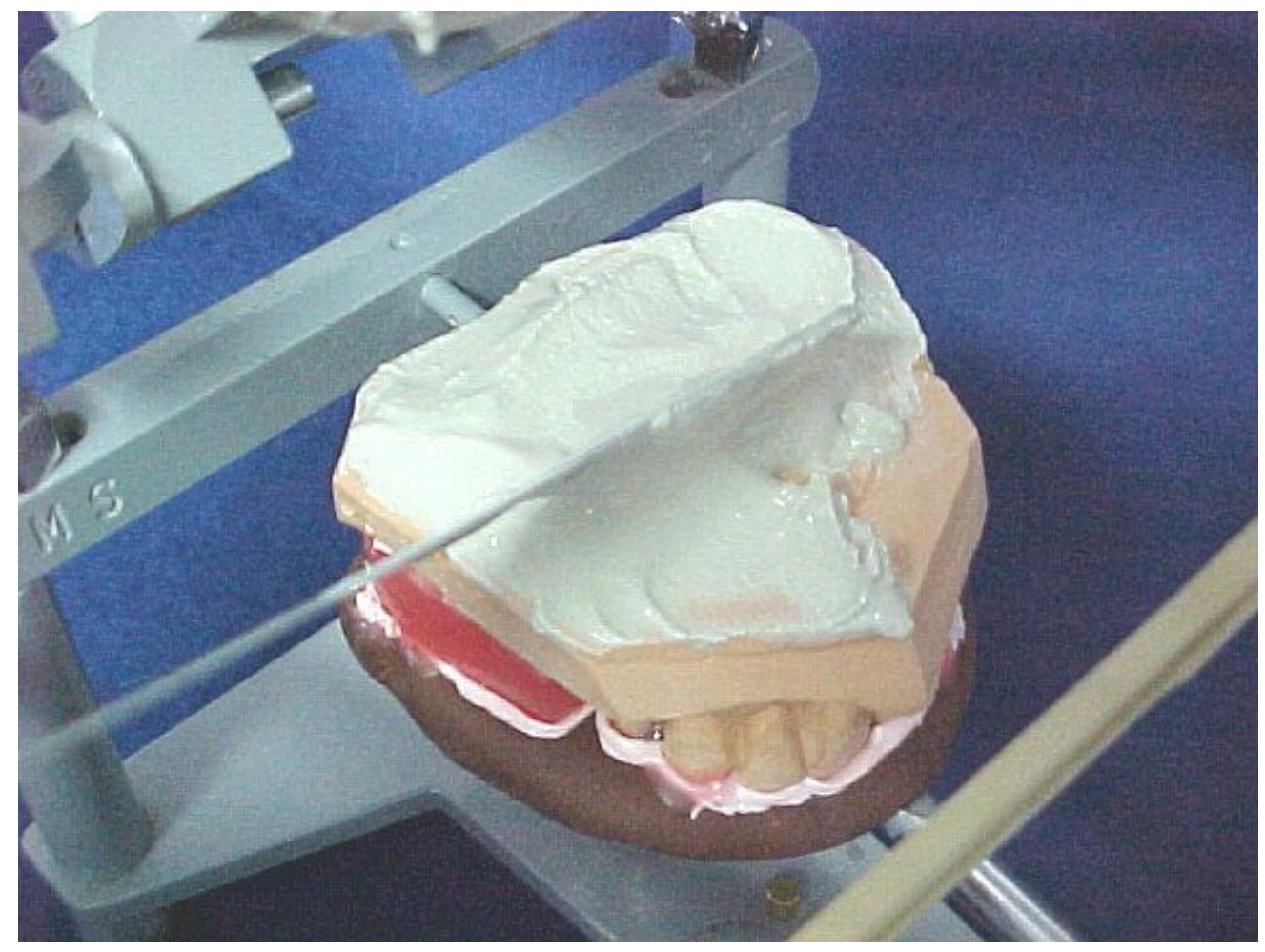

Figura 4.26 - 0 gesso deve ser espalhado sobre as retenções da base do modelo 


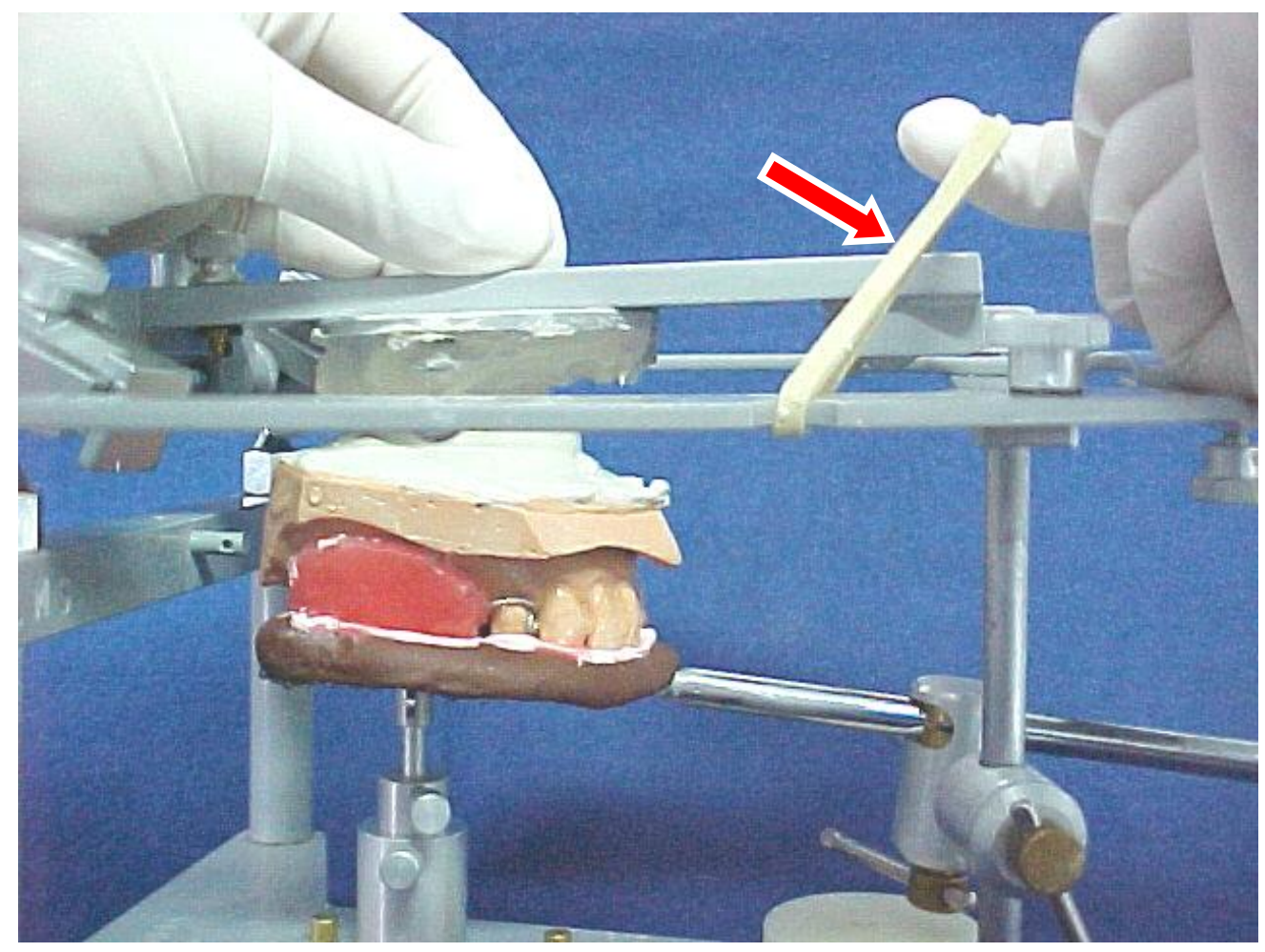

Figura 4.27 - Após a colocação do gesso para fixação do modelo, abaixa-se o ramo superior tomando-se o cuidado de posicionar corretamente a banda elástica (seta)

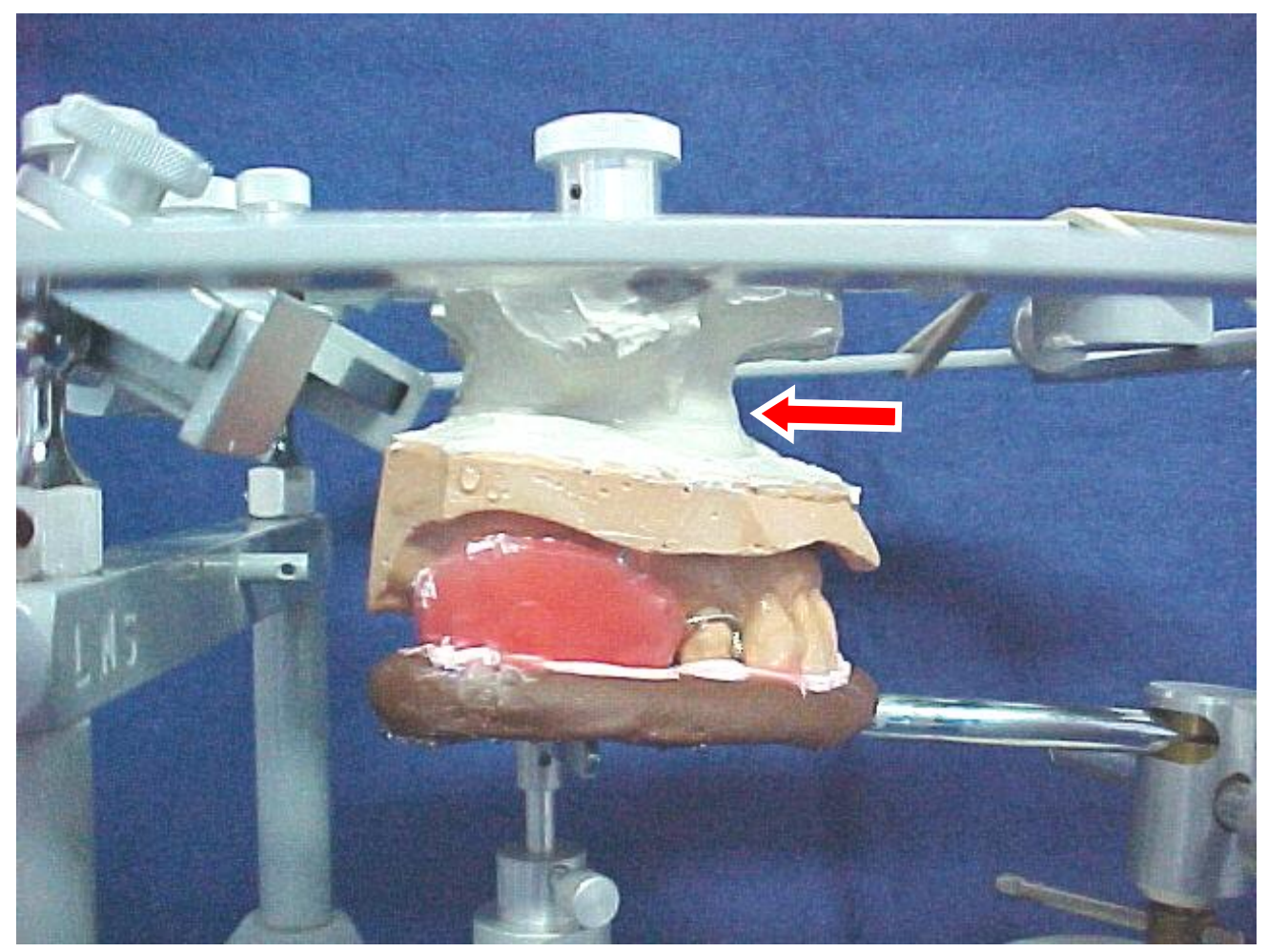

Figura 4.28 - Uma pequena quantidade de gesso (seta) é suficiente para garantir a fixação inicial do modelo e impedir os efeitos da expansão de cristalização do gesso 


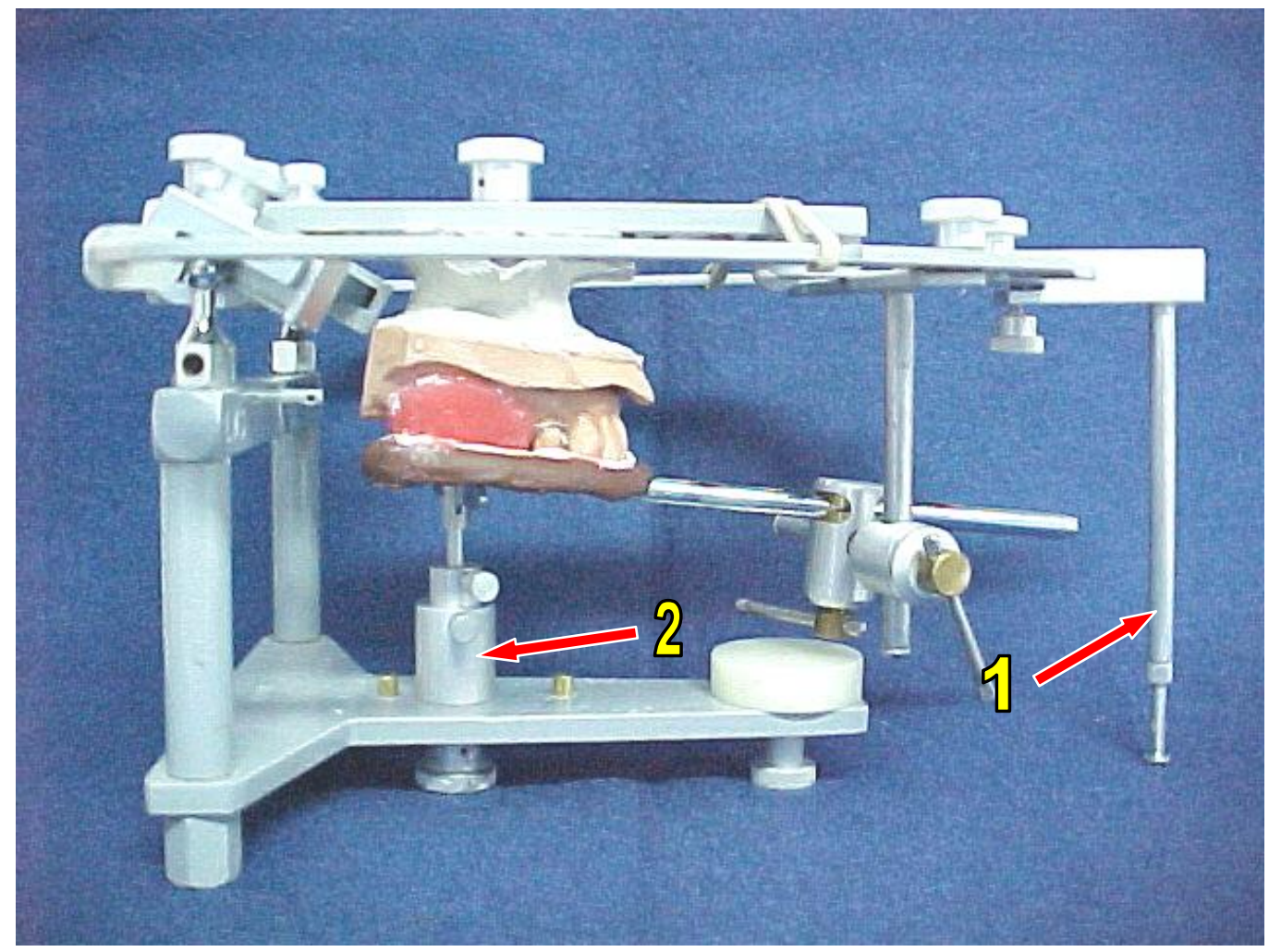

Figura 4.29 - Modelo de gesso montado pela técnica convencional. Observar a utilização do suporte anterior do arco facial (1) e o suporte inferior do garfo (2) para garantir a correta posição do modelo no articulador de maneira idêntica àquela ocupada pela maxila da paciente

Lembramos que o objetivo desse estudo foi o de especificamente comparar o posicionamento do modelo de gesso superior no articulador, utilizando-se duas técnicas de montagem, a fixação com gesso do modelo inferior à placa de montagem do ramo inferior do articulador não foi efetivada. 


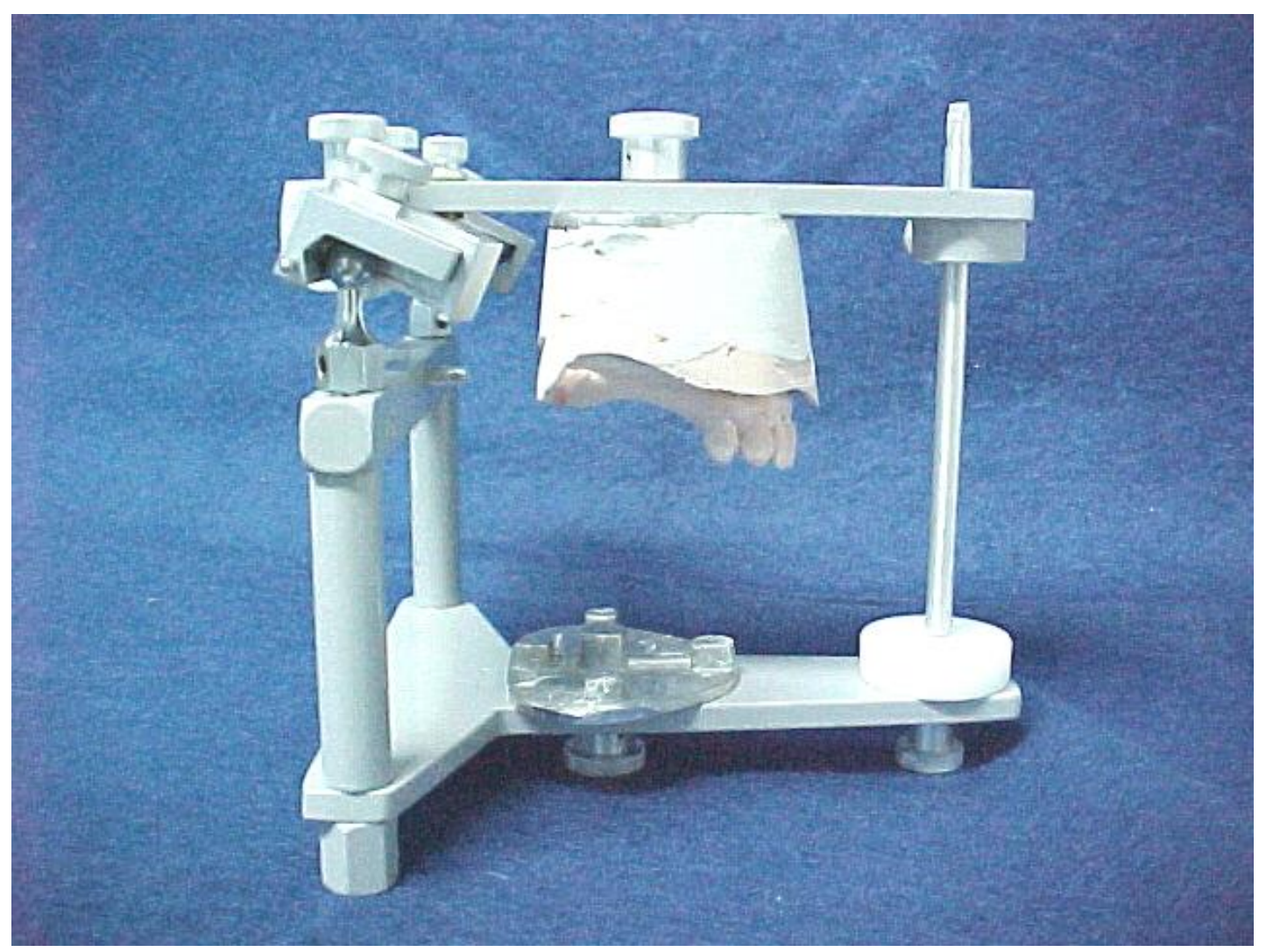

Figura 4.30 - Uma nova camada de gesso foi colocada para aumentar a resistência de fixação do modelo ao articulador, completando o acabamento final do modelo de gesso montado com a técnica convencional

\subsubsection{Técnica de montagem direta no articulador}

\subsubsection{Sistema de transferência direta do molde}

O sistema de transferência direta do molde para o articulador foi desenvolvido por Zanetti \& Ribas (1996, 1997). É conhecida como técnica Zanetti e vem sendo utilizado na clínica da Faculdade de Odontologia da Universidade da Cidade de São Paulo (UNICID) desde 1996. 
Trata-se de um processo de montagem que utiliza um dispositivo com o qual se consegue transferir o molde e os registros da arcada superior do paciente para o articulador numa só etapa, sem necessidade de se confeccionarem bases de prova e planos de orientação, utilização do garfo do arco facial e dos meios macios de transferência do modelo.

É apresentado num sistema conhecido por conjunto de moldeiras Zanetti (Teccom Ind. e Com. de Equip. Ltda., Brasil). O sistema é constituído por três partes:

(a) moldeira de transferência, formada por uma moldeira propriamente dita (tamanhos 1, 2, 3 e 4) com cabo cilíndrico com cerca de 100mm de comprimento por 6,3mm de diâmetro, confeccionados em aço inox (Figura 4.3, 1);

(b) sistema de fixação da moldeira no arco facial, confeccionado em alumínio (Figura 4.3, 2) e,

(c) cabo para confecção da moldeira funcional de transferência, para utilização em prótese total (Figura 4.3,3).

O sistema de fixação da moldeira de transferência feito em alumínio, divide-se em quatro segmentos:

(1) presilha convencional superior. É responsável pela fixação de todo o sistema no suporte principal (horizontal) do arco facial (Figuras 4.31 e 4.32).

(2) conexão posicionadora inferior. Essa conexão fixada ao arco facial por meio de uma presilha convencional superior. Ela tem a função de apreender o cabo da moldeira de transferência e auxiliar no registro da posição da moldeira (Figuras $4.31,4.32$ e 4.33$)$

(3) sistema de encaixe angular, o qual trabalha por meio de um duplo plano inclinado. Metade desse encaixe angular é parte integrante do lado voltado para o paciente da conexão posicionadora inferior. A outra metade faz parte do 
posicionador da moldeira que irá contatar com a conexão inferior do sistema (Figuras 4.31, 4.32 e 4.33) e,

(4) posicionador da moldeira de transferência, que é colocado no cabo da moldeira e tem por função registrar a exata posição que essa peça ocupa na boca do paciente (Figuras 4.31, 4.32 e 4.33).

A conexão posicionadora inferior possui um parafuso convencional que também transfixa a presilha superior para fixá-la ao arco facial (Figura 4.33, 1). Possui ainda um outro parafuso independente para fixação do cabo da moldeira, ambos localizados na parte inferior da conexão para facilitar o acesso (Figura 4.33, 4).

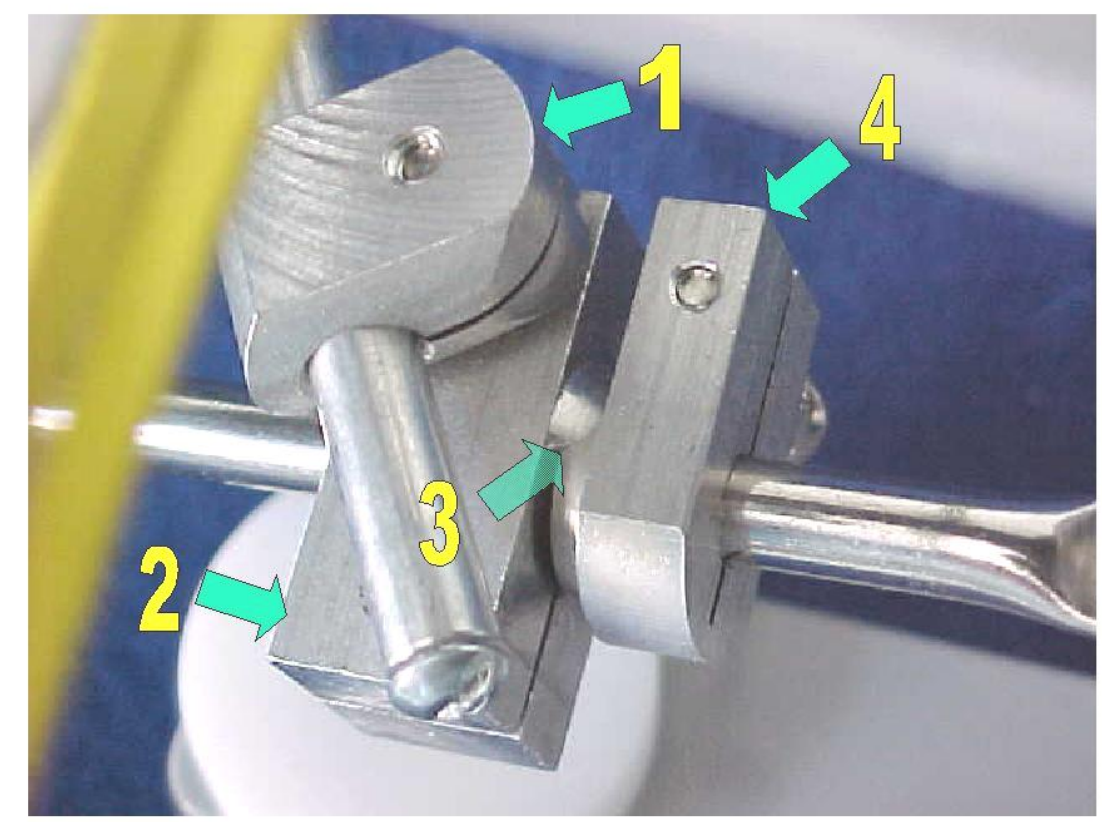

Figura 4..31 - Detalhe do sistema de fixação da moldeira de transferência (vista superior): (1) presilha superior; (2) conexão posicionadora inferior; (3) sistema de encaixe angular e, (4) posicionador da moldeira de transferência 
O posicionador da moldeira encaixa-se na conexão referida acima por meio de seus planos inclinados, de maneira a promoverem o registro da posição exata da moldeira no interior da boca do paciente em relação ao arco facial. Esse sistema permite controlar a posição da moldeira ântero-posteriormente e do eixo rotacional ao redor do cabo da moldeira.

O encaixe angular é ativado quando os lados que contém os planos inclinados, da conexão inferior e do posicionador da moldeira, são colocados firmemente um contra o outro e o parafuso do posicionador é apertado (Figura 4.33, 3).

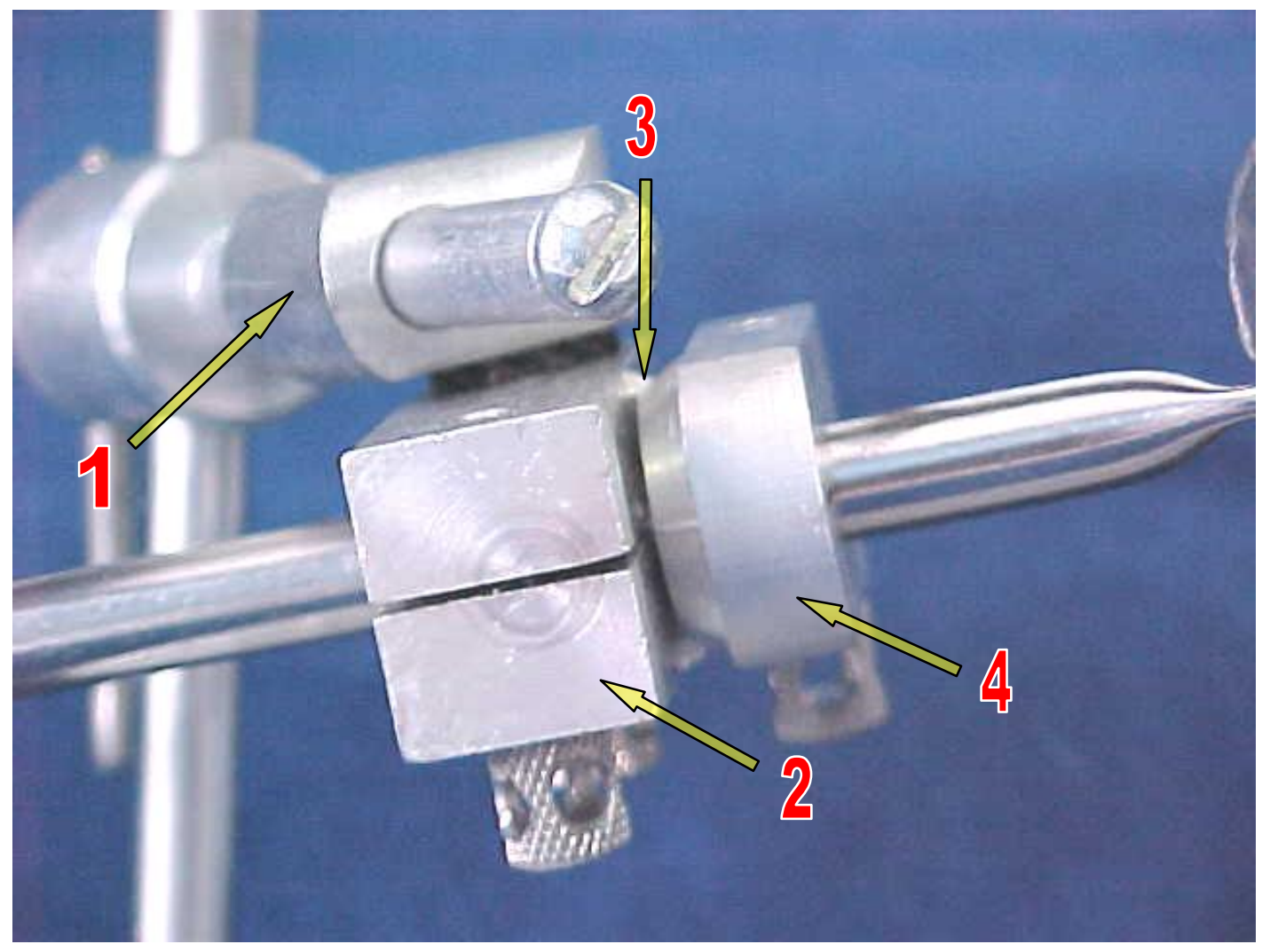

Figura 4.32 - Detalhe do sistema de fixação da moldeira de transferência (vista lateral esquerda): (1) presilha superior; (2) conexão posicionadora inferior; (3) sistema de encaixe angular e, (4) posicionador da moldeira de transferência 


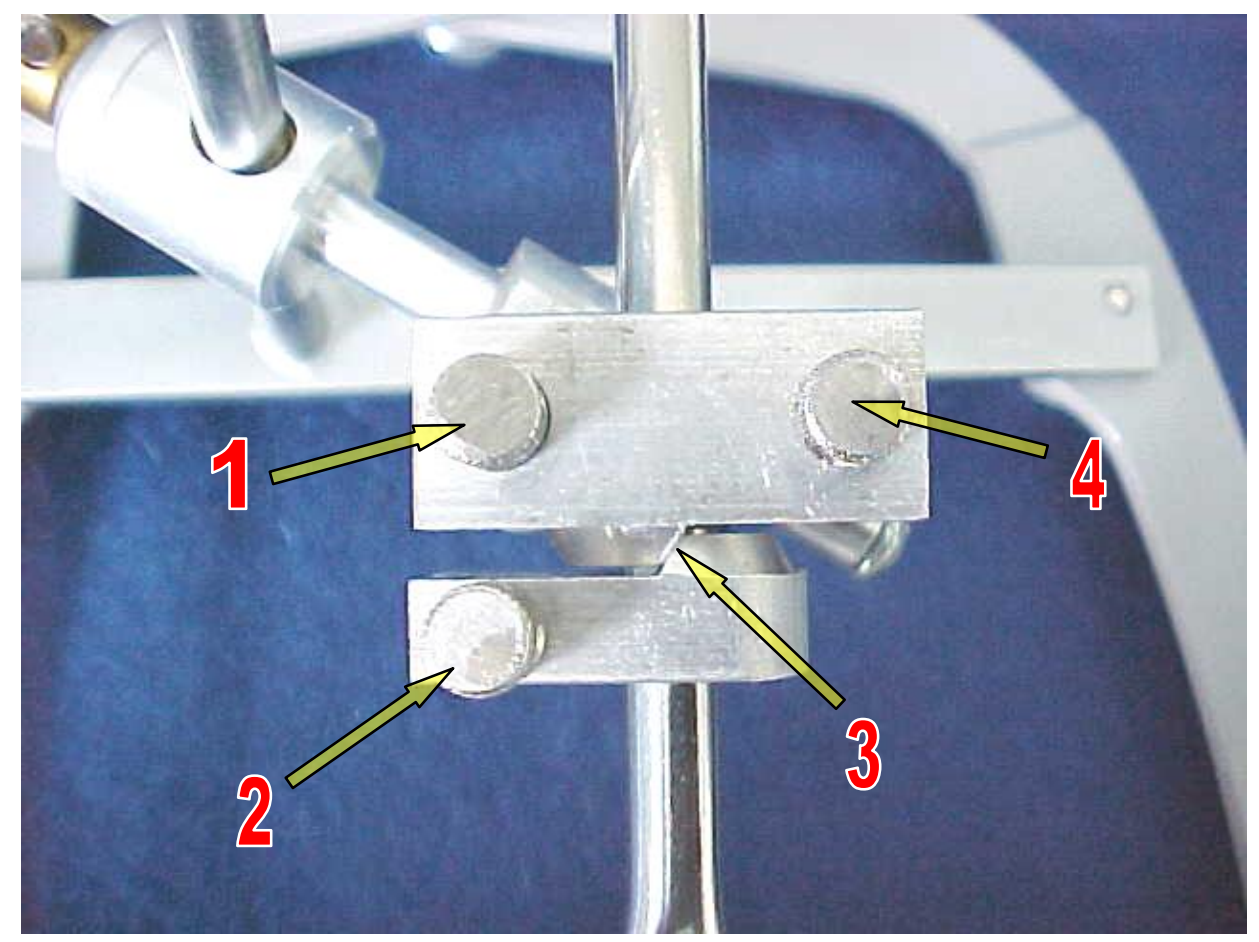

Figura 4.33 - Detalhe do sistema de fixação da moldeira de transferência (vista inferior): (1) parafuso convencional Transfixador; (2) parafuso de fixação do posicionador da moldeira; (3) sistema de encaixe angular com duplo plano inclinado e, (4) parafuso independente para fixação do cabo da moldeira

\subsubsection{Metodologia para moldagem e montagem no articulador com a técnica de transferência direta (Técnica Zanetti)}

Foi realizada uma demonstração de moldagem e obtenção do modelo de gesso, denominado de modelo $\mathrm{Z}$, com a técnica direta no articulador 01, sendo que essa montagem (Z01) serviu de controle para as demais dezenove, realizadas pelos dez operadores. Foram realizadas por esse método um total de vinte montagens diretas numeradas de Z01 a Z20, nos respectivos articuladores numerados de 01 a 20. 
Os procedimentos necessários a execução da moldagem e montagem no articulador utilizando essa técnica foram os seguintes:

1 - as moldeiras de transferência foram devidamente individualizadas com cera rosa $\mathrm{n}^{\mathrm{o}} 7$ (Wilson, Polidental Ind. e Com. Ltda., Brasil) segundo a técnica descrita por Zinner, 1987, com a finalidade de minimizar as variáveis decorrentes de diferentes espessuras do material de moldagem. Após o amolecimento em plastificador elétrico com água a $55^{\circ} \mathrm{C}$ (Mari-Jós Ind. e Com., Brasil) a cera foi inicialmente colocada na região da moldeira correspondente ao palato. Nesse procedimento de acomodação da cera na moldeira, também fez-se uso de uma tocha de chama dirigida (Hot Shot, Blazer Co., USA). Após um banho homogeneizador no plastificador, a moldeira foi colocada na boca da paciente para adaptação da cera à anatomia da região do palato. Na seqüência, a cera foi colocada em toda a extensão dos rebordos residuais até o fundo de sulco vestibular. Procedeu-se da mesma maneira que na região do palato. Esse procedimento foi repetido várias vezes até que a cera estivesse adequadamente adaptada ao palato, rebordos residuais e fundo de sulco vestibular. Na região do bordo anterior da moldeira foi colocada cera periférica (Kota Ind. e Com. Ltda., Brasil) plastificada com auxílio da tocha de chama dirigida e homogeneizada em plastificador a $55^{\circ} \mathrm{C}$, sendo a moldeira colocada na boca da paciente para adaptação da cera ao fundo de sulco vestibular (Figura 4.34). 


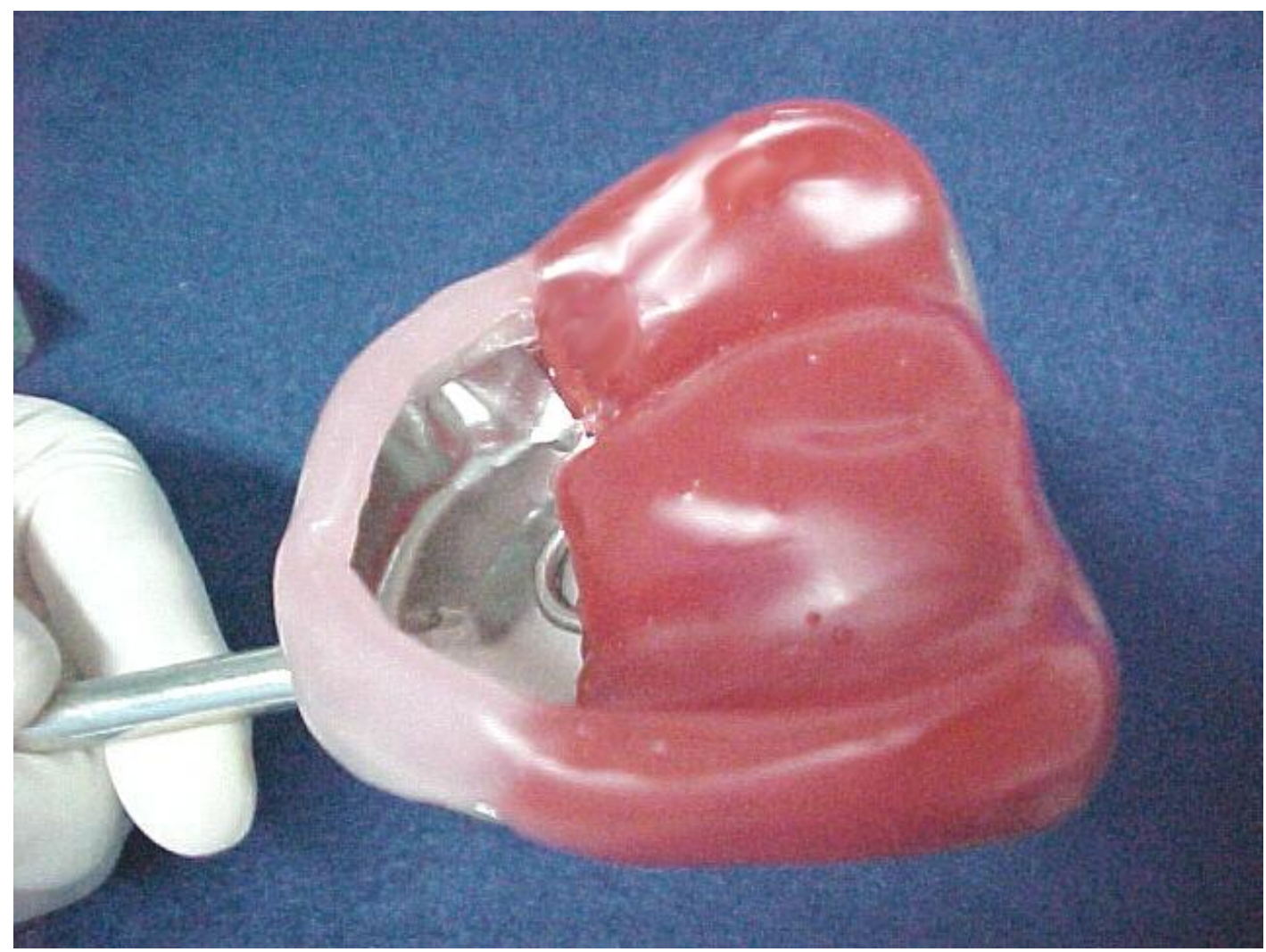

Figura 4.34 - Individualização da moldeira de transferência finalizada

2 - removeu-se uma camada de $3 \mathrm{~mm}$ de cera da região dos rebordos e palato para propiciar uma espessura uniforme ao material de moldagem (Valderhaug \& Flфystrand, 1984; Mendez, 1985). Para promover a retenção do alginato à cera, foram feitas ranhuras em toda a extensão da cera (Figura 4.35). 


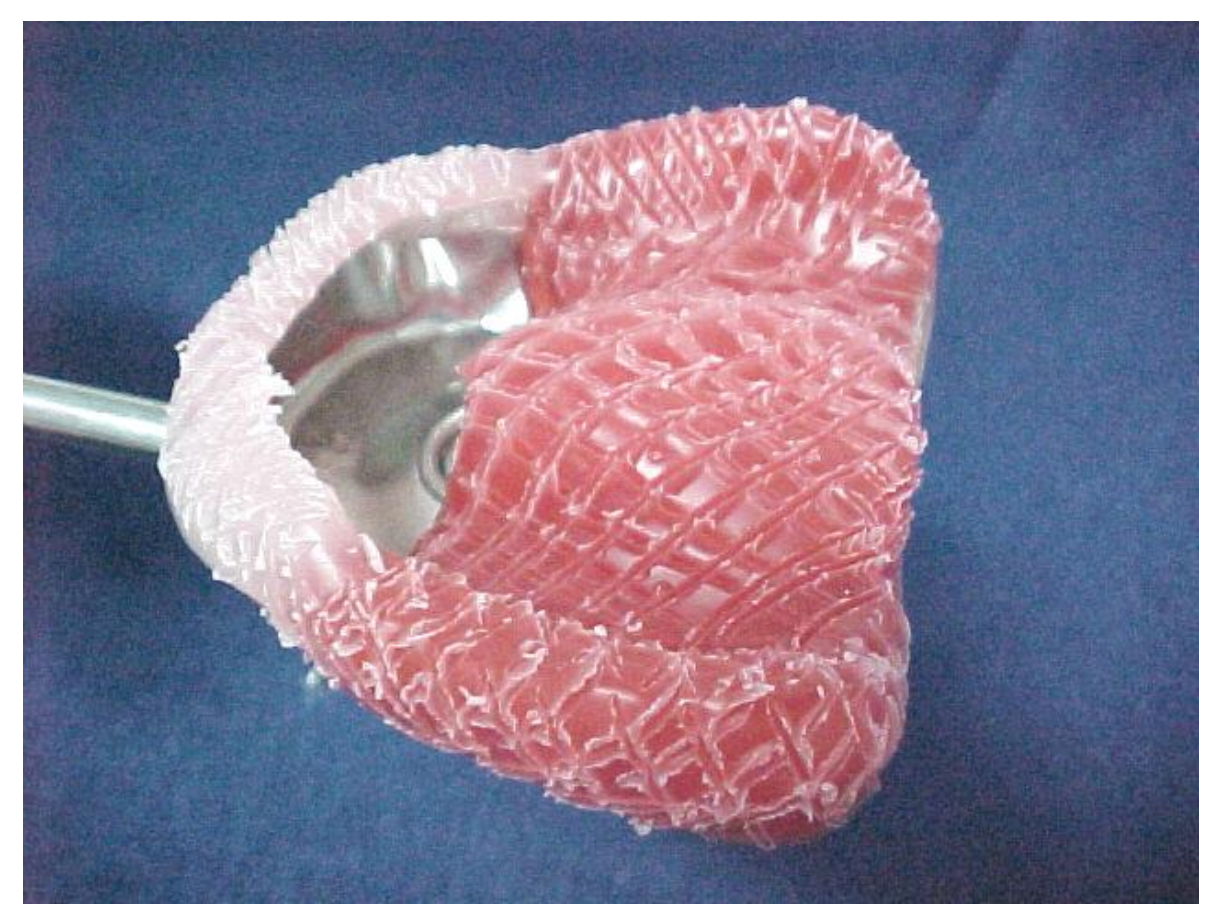

Figura 4.35 - Para garantir a retenção do alginato deve-se fazer retenções em toda a extensão da cera

3 - utilizou-se para essa técnica um material de moldagem à base de alginato tixotrópico isento de pó (dust free) de presa rápida (Hydrogum, Zhermack® S.p.A., Itália). O pote de alginato foi virado de fundo para cima umas duas ou três vezes, para homogeneizar os componentes do pó que se sedimentam. Para a moldeira escolhida foram utilizadas três porções do pó para três medidas de água à temperatura ambiente, sendo que a colher e o medidor de água são utensílios fornecidos pelo fabricante. Primeiramente foi colocada a quantidade de pó necessária e depois a água. A mistura foi espatulada por 30 segundos e colocada na moldeira. Ao mesmo tempo pediu-se à paciente para fazer bochechos com água morna para remoção da saliva mais mucilaginosa. A moldeira foi inserida na boca e comprimida suavemente até sua correta posição. Assim permaneceu durante 60 segundos após o desaparecimento da viscosidade e brilho superficial do alginato (Figura 4.36, $a$ ). 
4 - após a presa do material, a moldeira foi deixada em posição na boca para montagem do arco facial. O posicionador da moldeira foi colocado no cabo da mesma, até próximo do lábio da paciente (Figura 4.36, b). Os passos seguintes foram auxiliados por uma assistente que manteve a posição correta da moldeira na boca, sem pressão.

5 - o arco facial foi, então, colocado na face da paciente, ao mesmo tempo em que a conexão posicionadora inferior do sistema de fixação foi colocada no cabo da moldeira. A paciente foi instruída a guiar as duas olivas do arco simultaneamente em direção aos meatos acústicos externos, da mesma maneira que o faria com um estetoscópio (Figura 4.36, c). Depois disso apertaram-se os três parafusos da parte superior do arco facial propriamente dito (Figura 4.36, $d$ ).

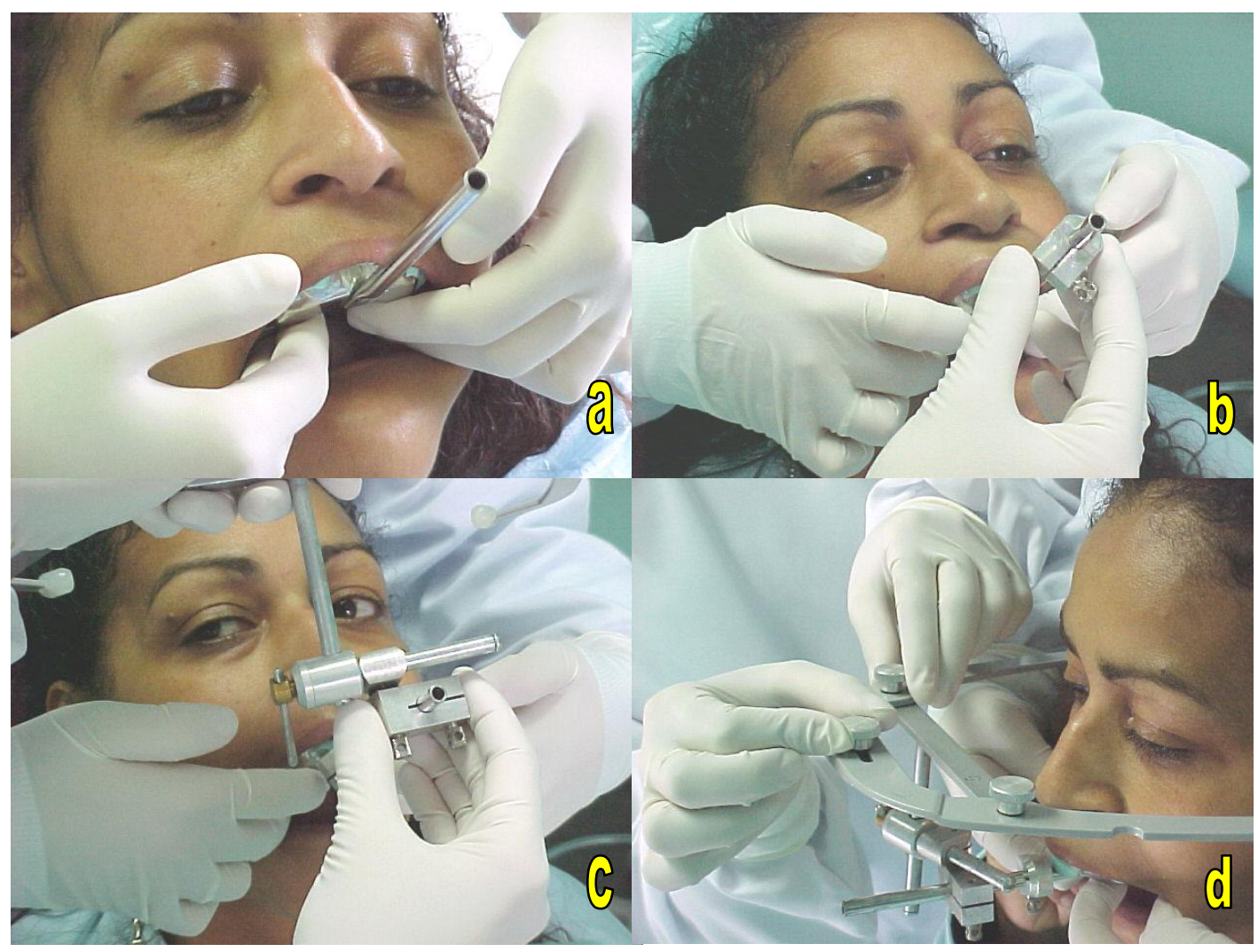

Figura 4.36 - Seqüência de montagem do arco facial pela técnica de transferência direta: (a) moldagem da arcada superior; (b) colocação do posicionador da moldeira; (c) colocação do arco facial e, (d) aperto dos 3 parafusos da parte superior do arco 
6 - colocou-se o relator nasal ou suporte nasal (nasion), tomando-se o cuidado para verificar a posição do arco facial em relação ao plano de referência horizontal ou plano de Frankfurt (Figura 4.37).

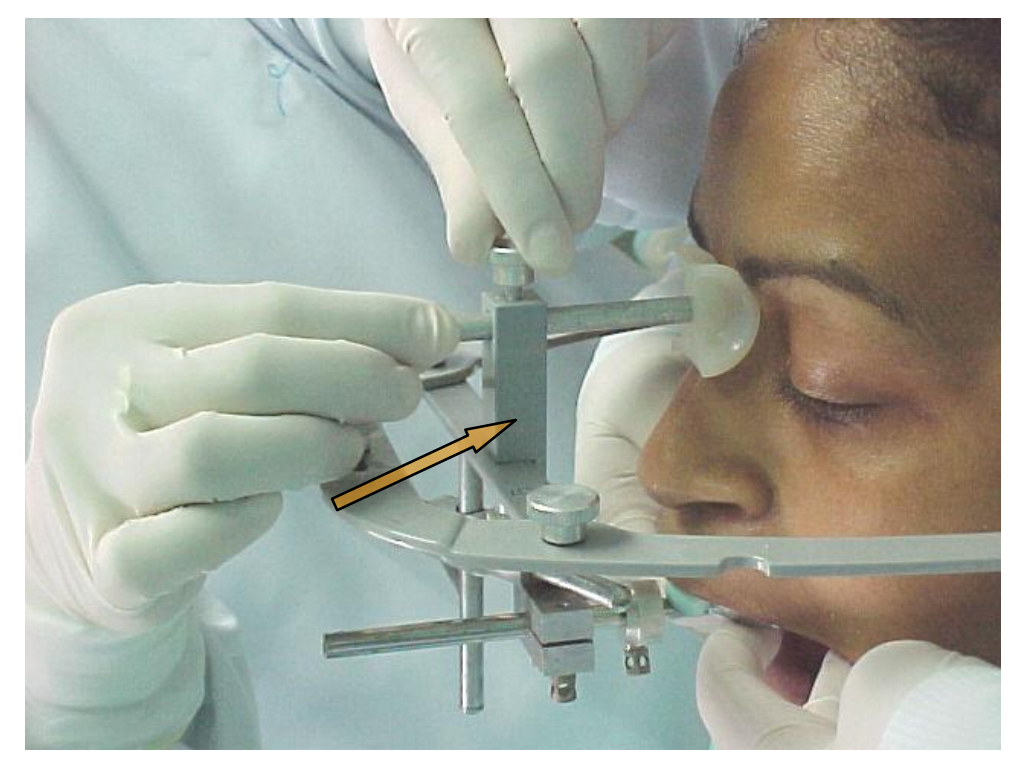

Figura 4.37 - Colocação do suporte nasal ou nasion (seta)

Observação:

Vale lembrar que para realização dos ajustes necessários, é sempre indispensável que o arco seja estabilizado com a mão livre (normalmente a esquerda), enquanto a outra (normalmente a direita) é usada para apertar os parafusos. A seqüência de ajustes do arco facial deve obedecer a seguinte ordem de regulagem:

7 - parafuso da união universal do suporte horizontal principal do arco (Figura 4.38). 


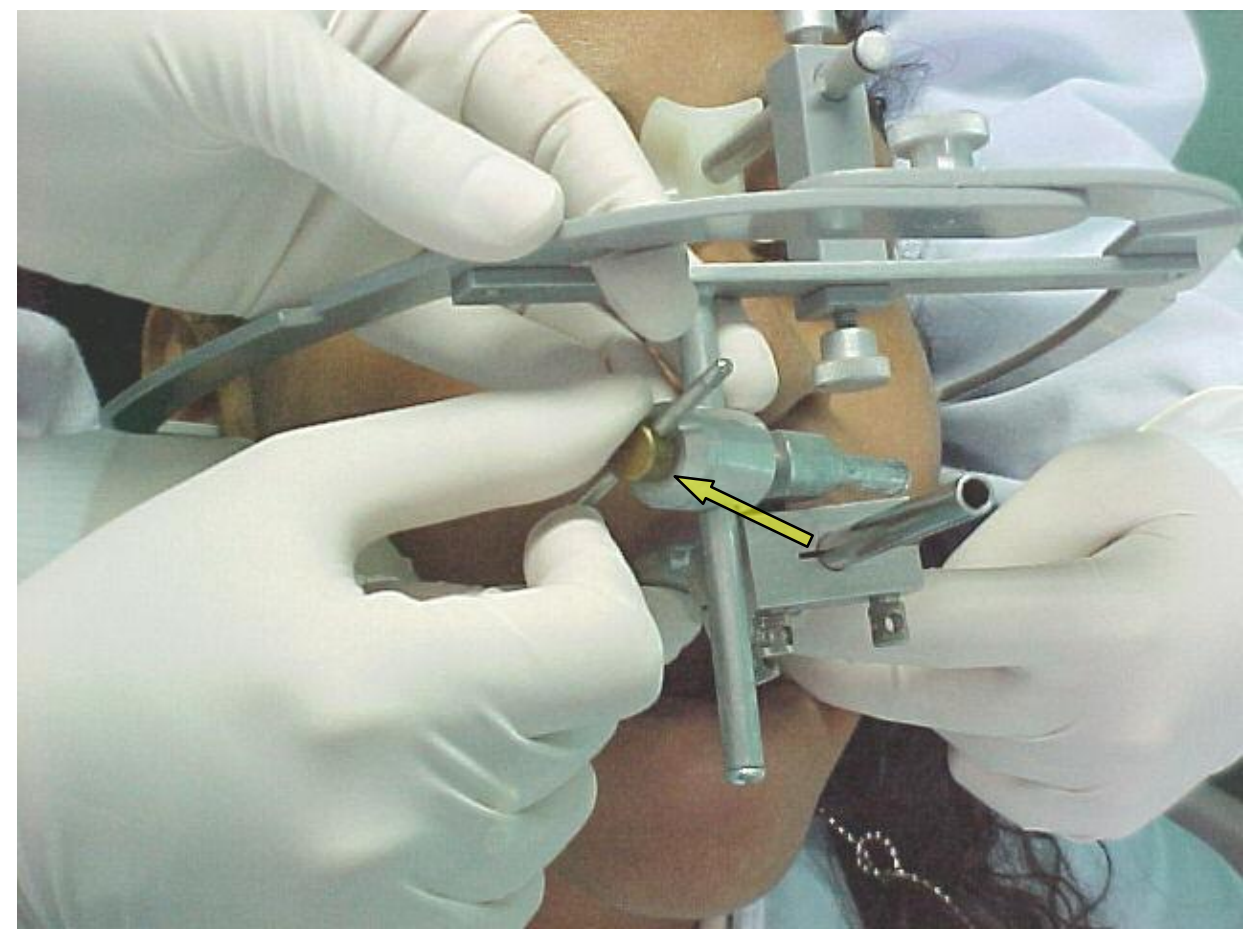

Figura 4.38 - Aperto do parafuso da união universal do suporte principal do arco facial (seta), tomando-se o cuidado de manter a estabilidade do arco com a outra mão

8 - parafuso transfixador da conexão posicionadora inferior do sistema de fixação e presilha superior, fixando-as no suporte principal (Figura 4.39).

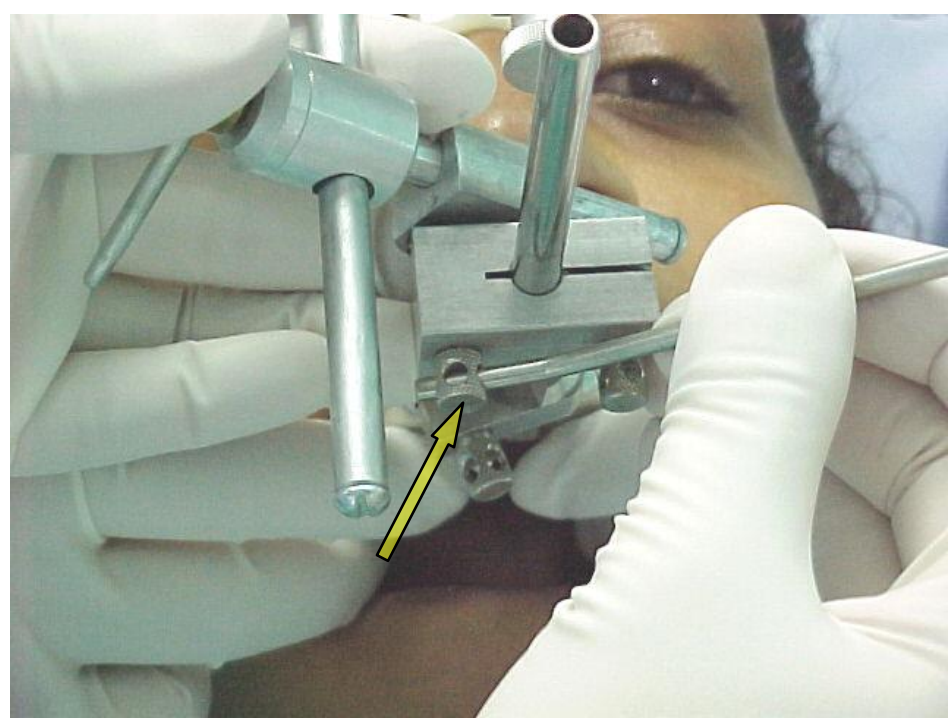

Figura 4.39 - Aperto do parafuso transfixador da conexão posicionadora inferior (seta) 
9 - encaixa-se o posicionador da moldeira na conexão inferior por meio de seus planos inclinados e aperta-se seu parafuso (Figura 4.40, $a$ ).

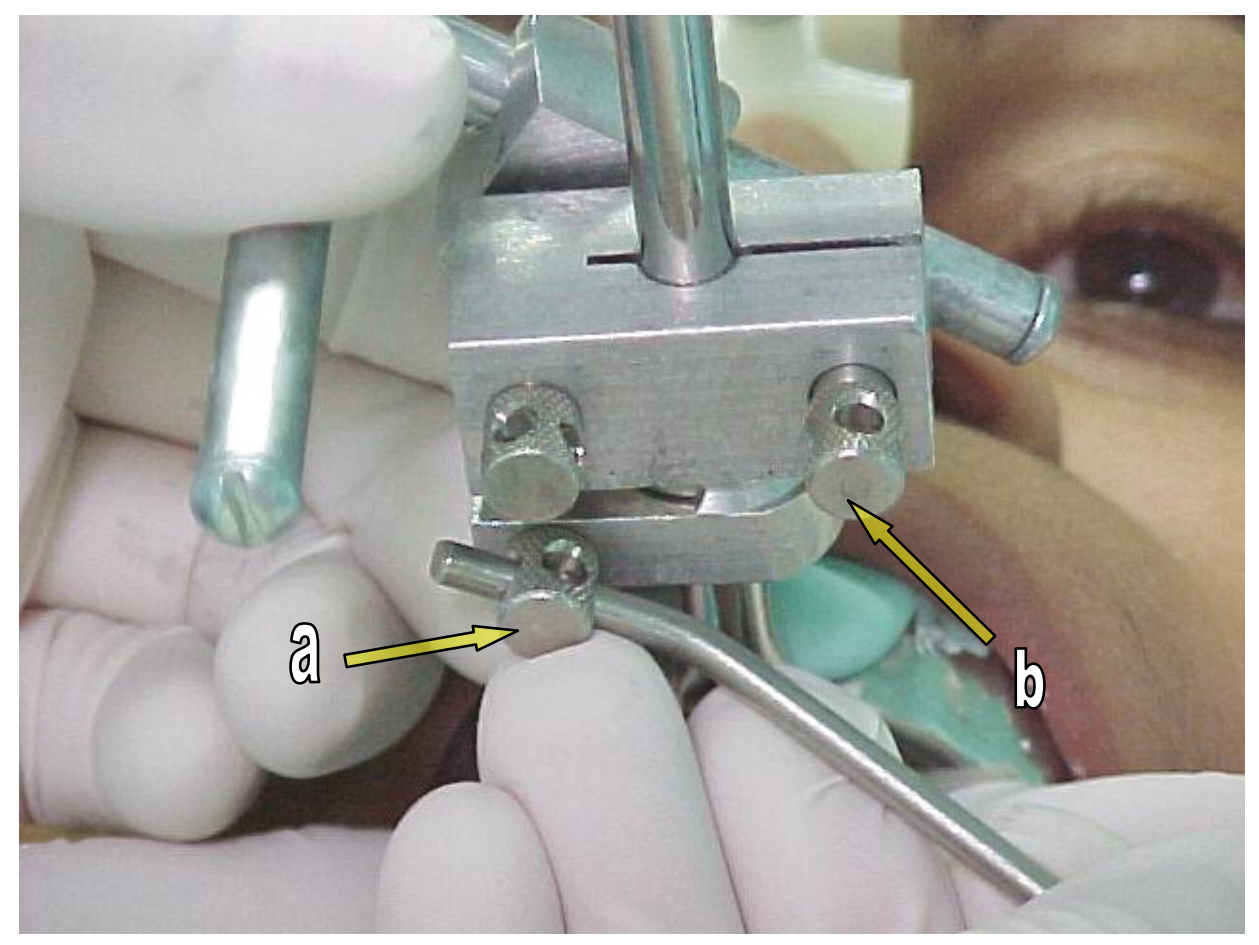

Figura 4.40 - Aperto do parafuso do posicionador da moldeira (a); não é necessário nessa fase apertar o parafuso independente de fixação da haste da moldeira $(b)$

Não é necessário nessa fase, apertar o parafuso independente que fixa o cabo da moldeira (Figura 4.40, b). O sistema de fixação da moldeira de transferência, dessa maneira, permanece totalmente ajustado e travado e, o arco em posição no plano de Frankfurt (Figura 4.41, setas). 


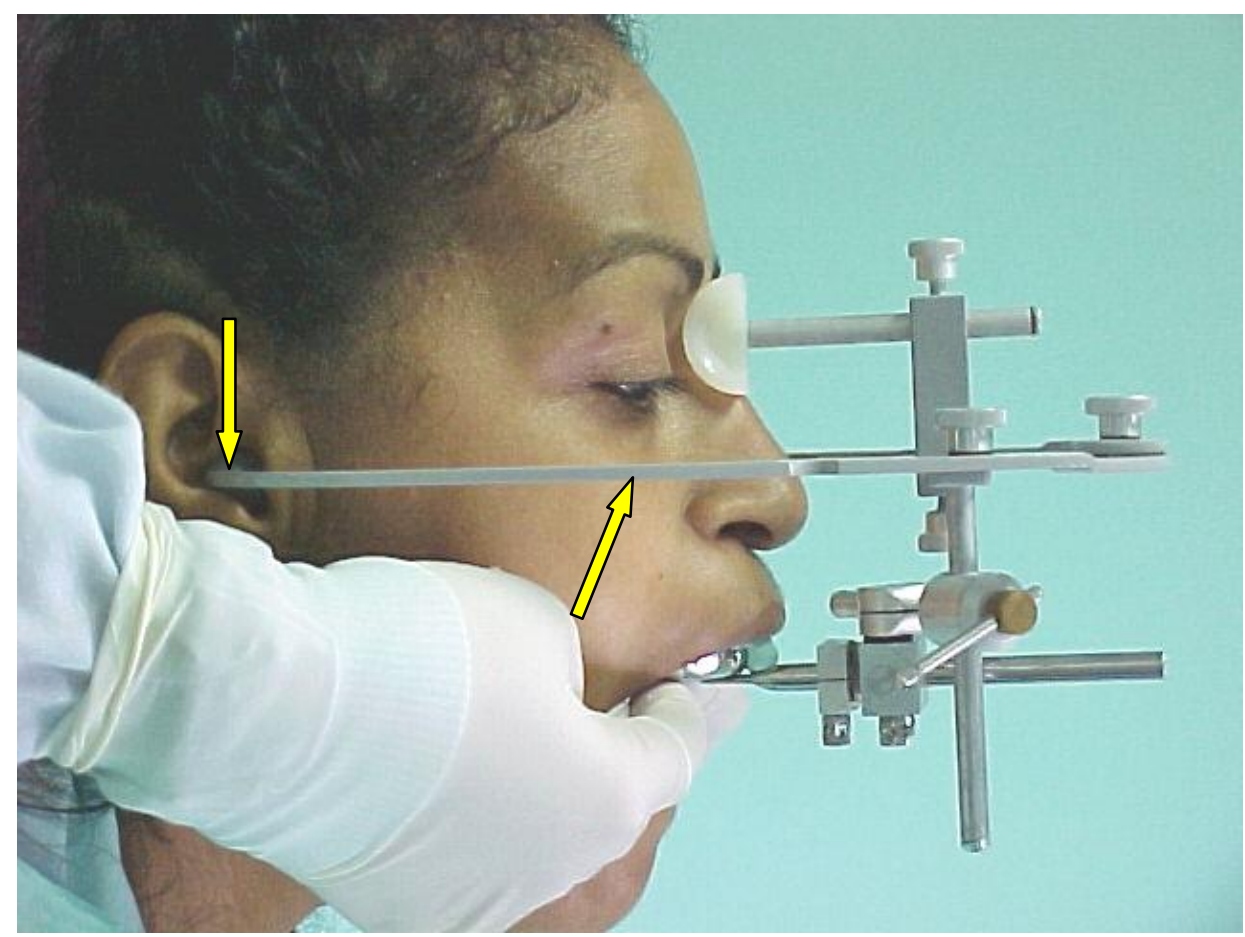

Figura 4.41 - Observar o correto posicionamento do arco facial em relação ao plano de referência horizontal (plano de Frankfurt)

10 - para remover o arco facial, deve-se retirar o suporte nasal e afrouxar os três parafusos da parte superior do mesmo e removê-lo (Figura 4.42) Vale lembrar a importância de se colocar o arco facial apoiado pelo próprio arco numa bancada e nunca apoiado pela moldeira, o que poderia alterar a posição da mesma. 


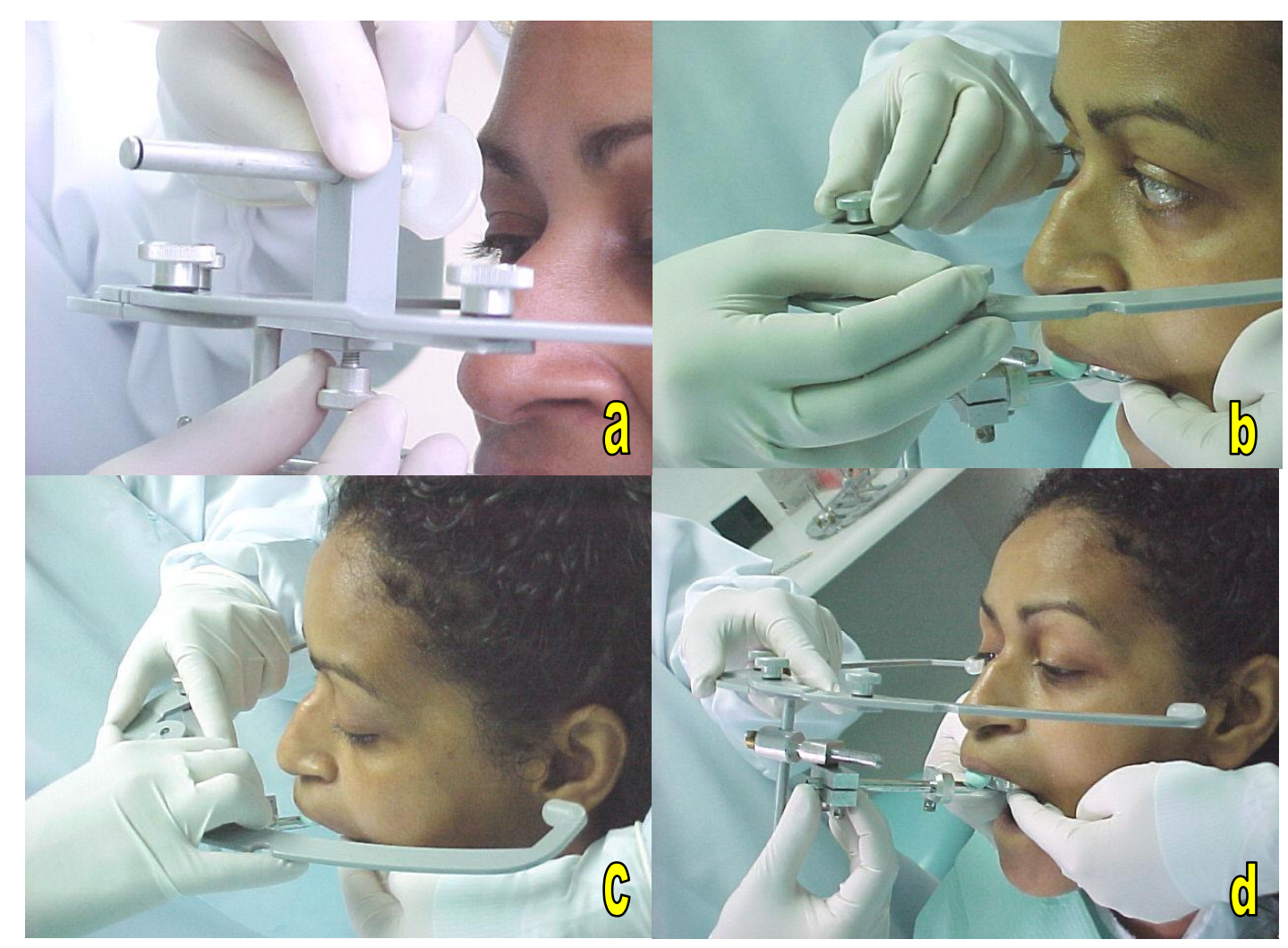

Figura 4.42 - (a) remove-se o suporte nasal; (b) afrouxa-se os parafusos da parte superior do arco; (c) desaloja-se as olivas dos meatos acústicos externos e, (d) desliza-se a conexão inferior pelo cabo da moldeira até soltar-se totalmente da mesma

11 - a moldeira de transferência permanece na boca com o posicionador da moldeira fixado ao cabo da mesma, registrando precisamente sua posição (Figura 4.43).

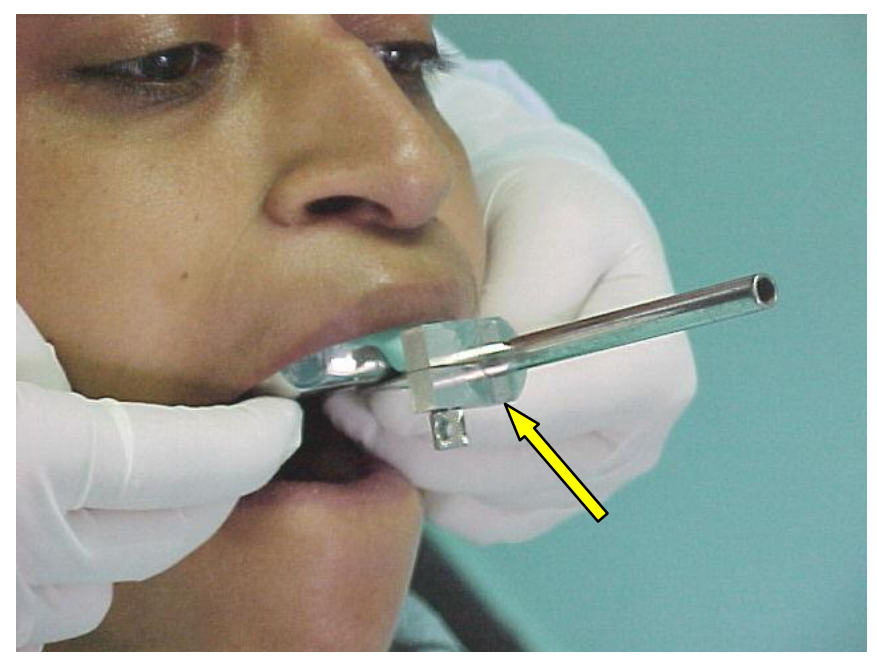

Figura 4.43 - Moldeira de transferência com o posicionador (seta) fixado em seu cabo 
12 - na etapa subsequente removeu-se a moldeira da boca do paciente (Figura 4.44).

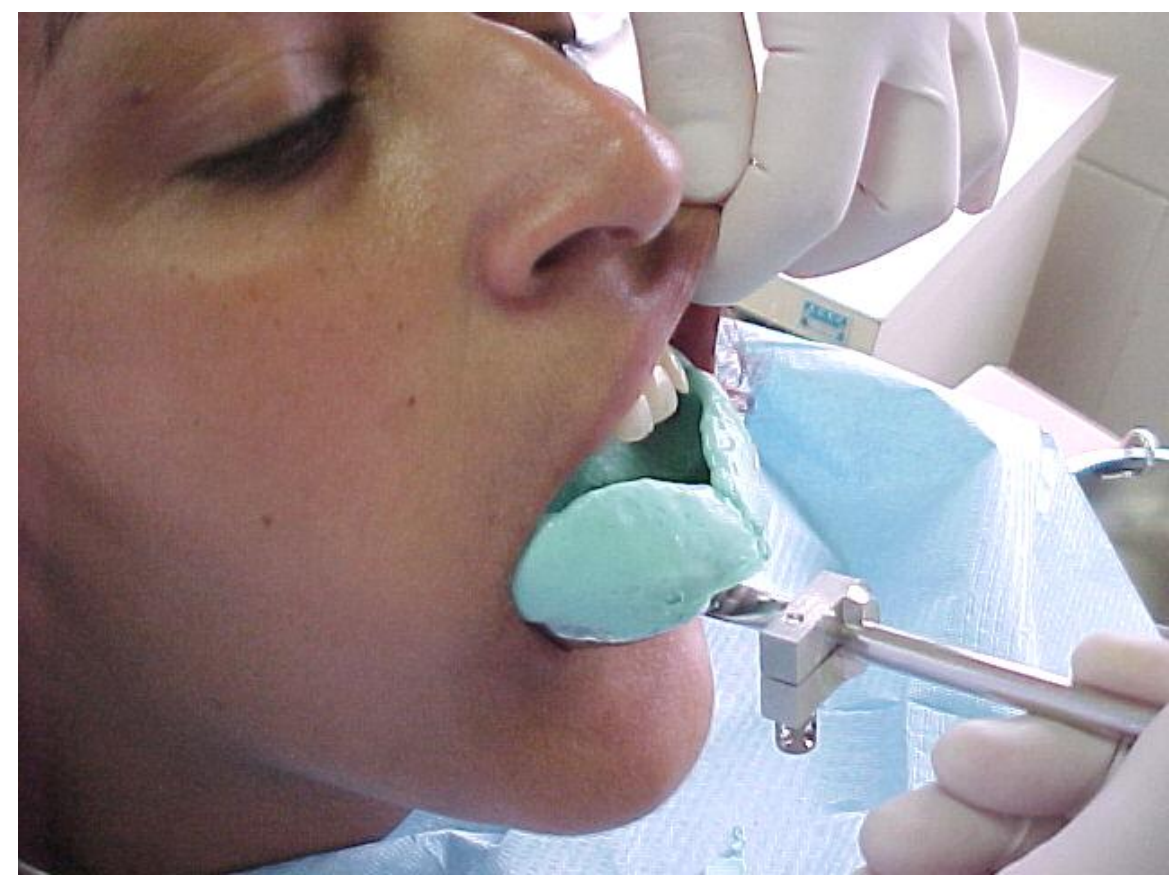

Figura 4.44 - Remoção da moldeira de transferência

13 - estando o molde perfeito, deu-se continuidade aos procedimentos. Antes de vazar o gesso no molde, preparou-se o articulador para receber o conjunto arco facial+moldeira de transferência+molde. Colocou-se a banda elástica que acompanha o articulador no arco facial no local próprio, isto é, na depressão lateral localizada nas duas metades do arco, próxima ao suporte geral do arco (Figura 4.45, a).

14 - colocou-se o suporte inferior da moldeira (Figura 4.45, b) e o suporte anterior do arco facial (Figura 4.45, c), com a moldeira em posição para os ajustes necessários dos suportes. Os demais ajustes do articulador foram realizados da mesma forma adotada na técnica convencional. 


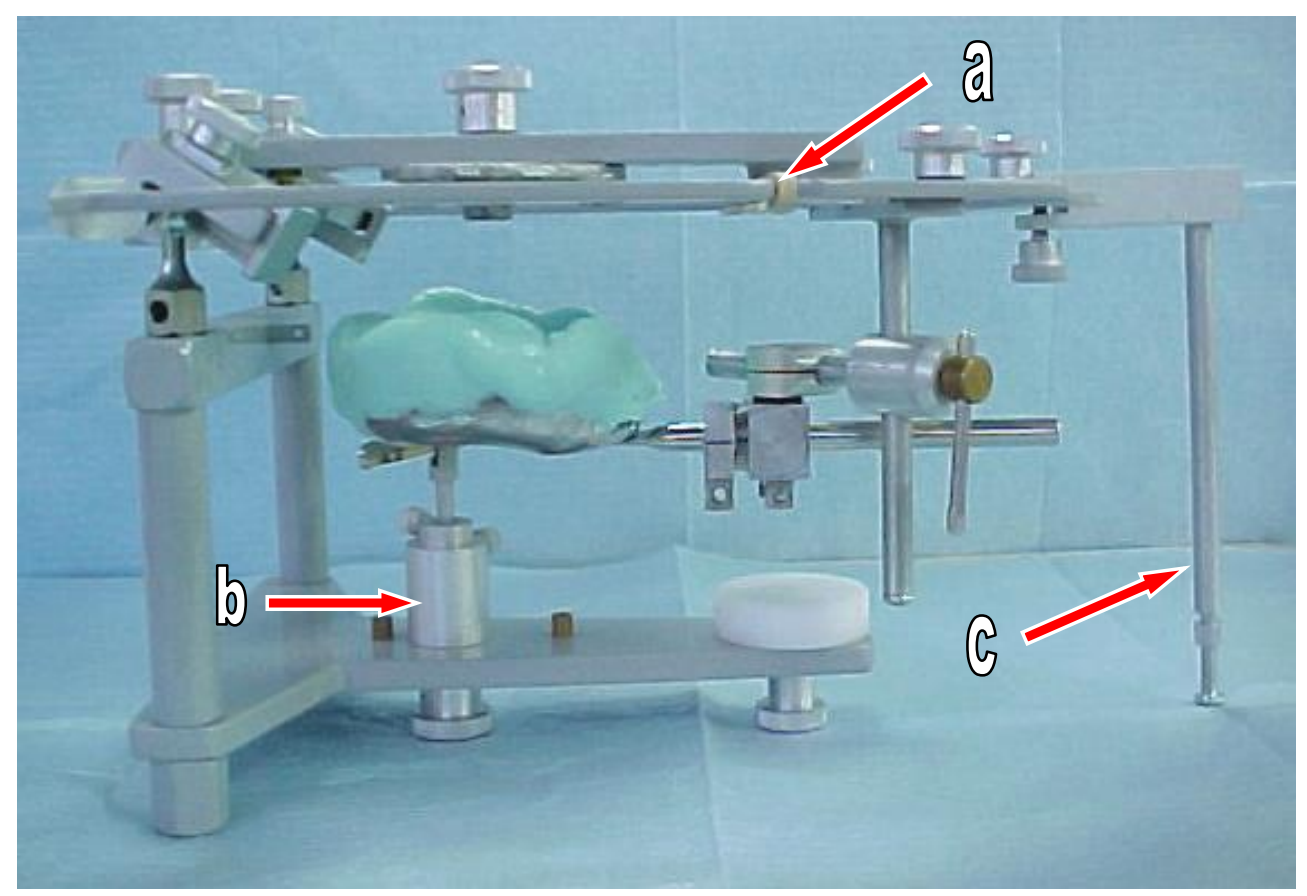

Figura 4.45 - Colocação correta da banda elástica (a); ajuste dos suportes inferior da moldeira $(b)$ e, anterior do arco facial (c)

15 - o molde, então, foi vazado com gesso pedra comum (Herodent, Vigodent Ind. $e$ Com. Ltda., Brasil), sob vibração até o molde ser completado até seu bordo. Seguiu-se as orientações de manipulação do gesso fornecidas pelo fabricante (100 partes de gesso para 30 de água, à temperatura ambiente). Os procedimentos e cuidados para manipulação do gesso foram os mesmos mencionados para a técnica convencional (Figura 4.46). 


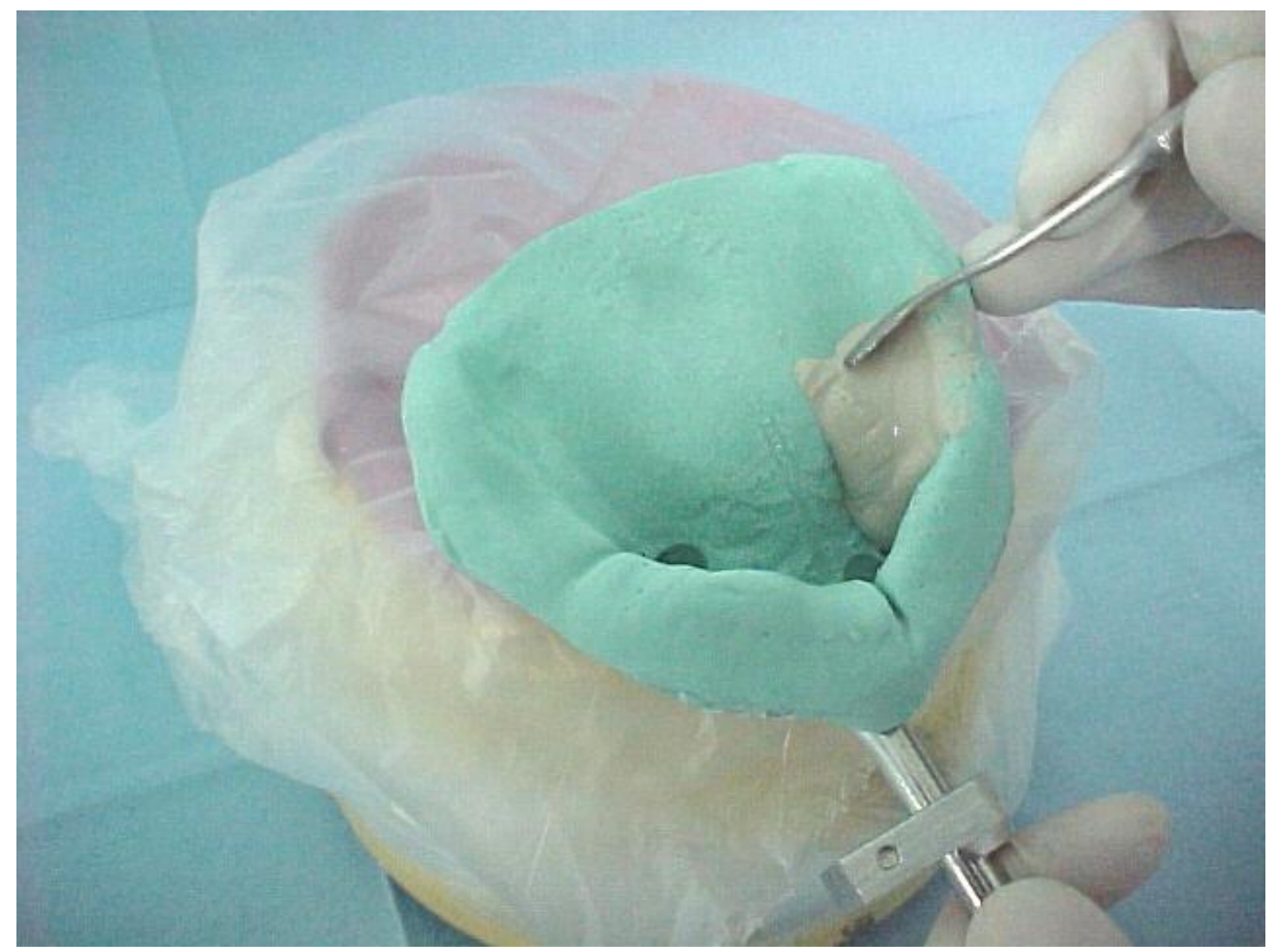

Figura 4.46 - Vazamento do molde sob vibração. Observar que o posicionador da moldeira de transferência permanece no cabo da mesma, mantendo o registro de sua posição original na boca

16 - em seguida, a moldeira com o molde já vazado foi colocada no arco (Figura 4.47,

a), apertando-se o parafuso independente da conexão inferior que fixa o cabo da moldeira (Figura 4.47, $b$ ). 


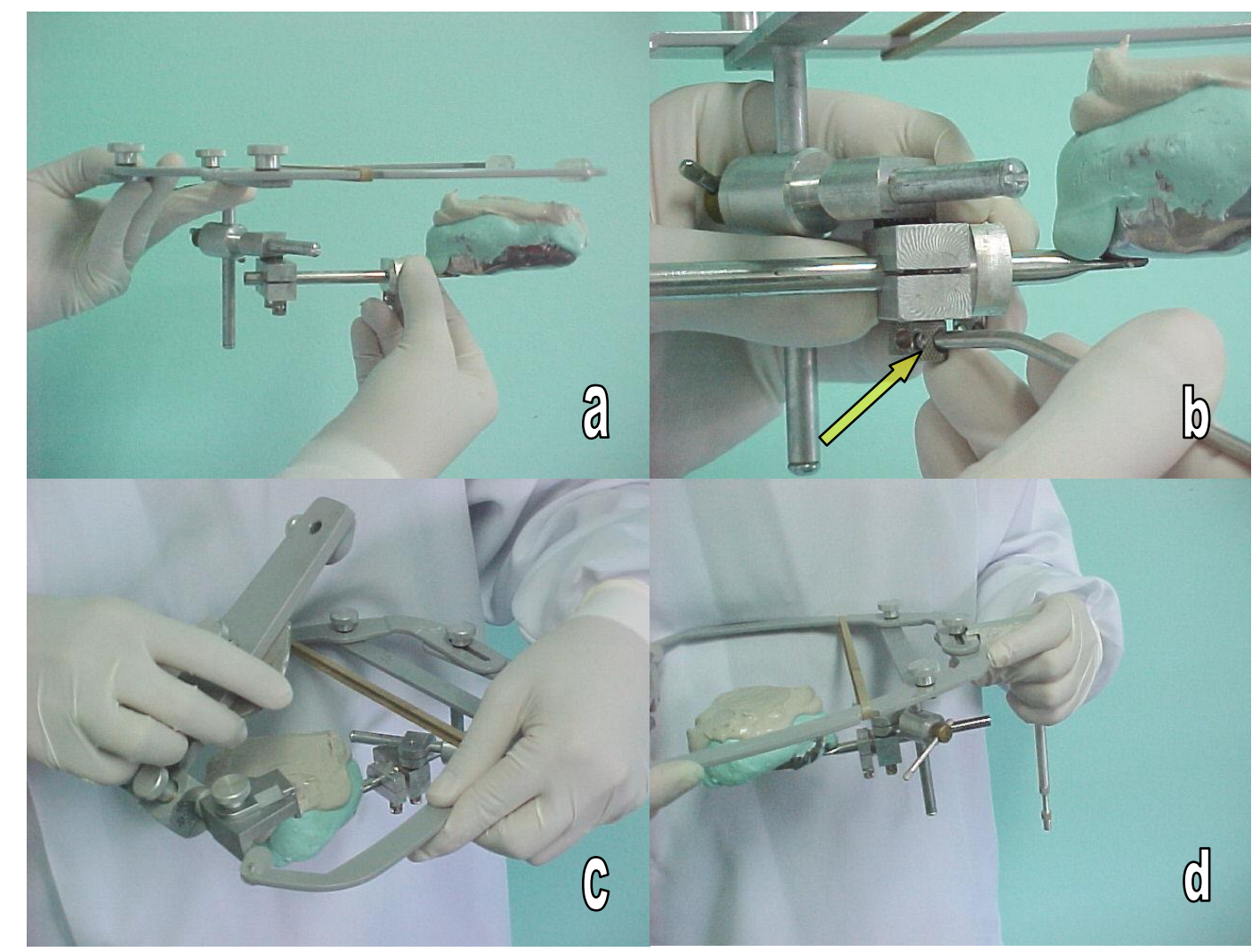

Figura 4.47 - (a) colocação do conjunto molde vazado+moldeira de transferência no arco facial; (b) o parafuso independente da conexão inferior (seta) é apertado para fixar o cabo precisamente no arco; (c) colocação do arco no ramo superior $e,(d)$ colocação do suporte anterior no arco

17 - esse conjunto (arco facial+moldeira+molde vazado) foi montado no articulador já previamente ajustado e, com a mesma porção de gesso utilizada para o vazamento do molde, foi completada a fixação do futuro modelo (molde vazado) à placa de montagem do ramo superior do articulador. O gesso foi colocado primeiramente na placa de montagem (Figura 4.48) e depois no molde já vazado (Figura 4.49). 


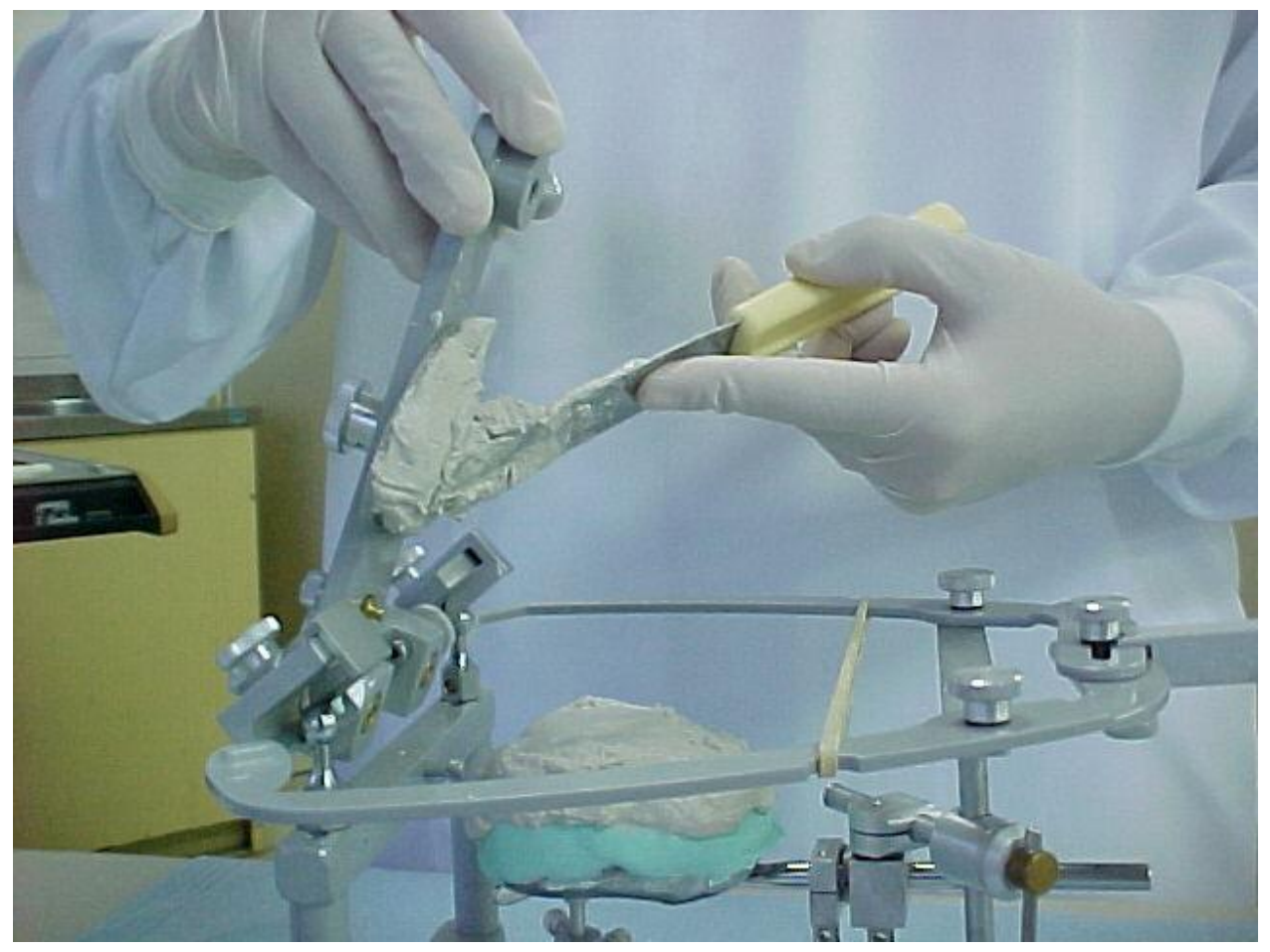

Figura 4.48 - Coloca-se o gesso primeiramente na placa de montagem superior

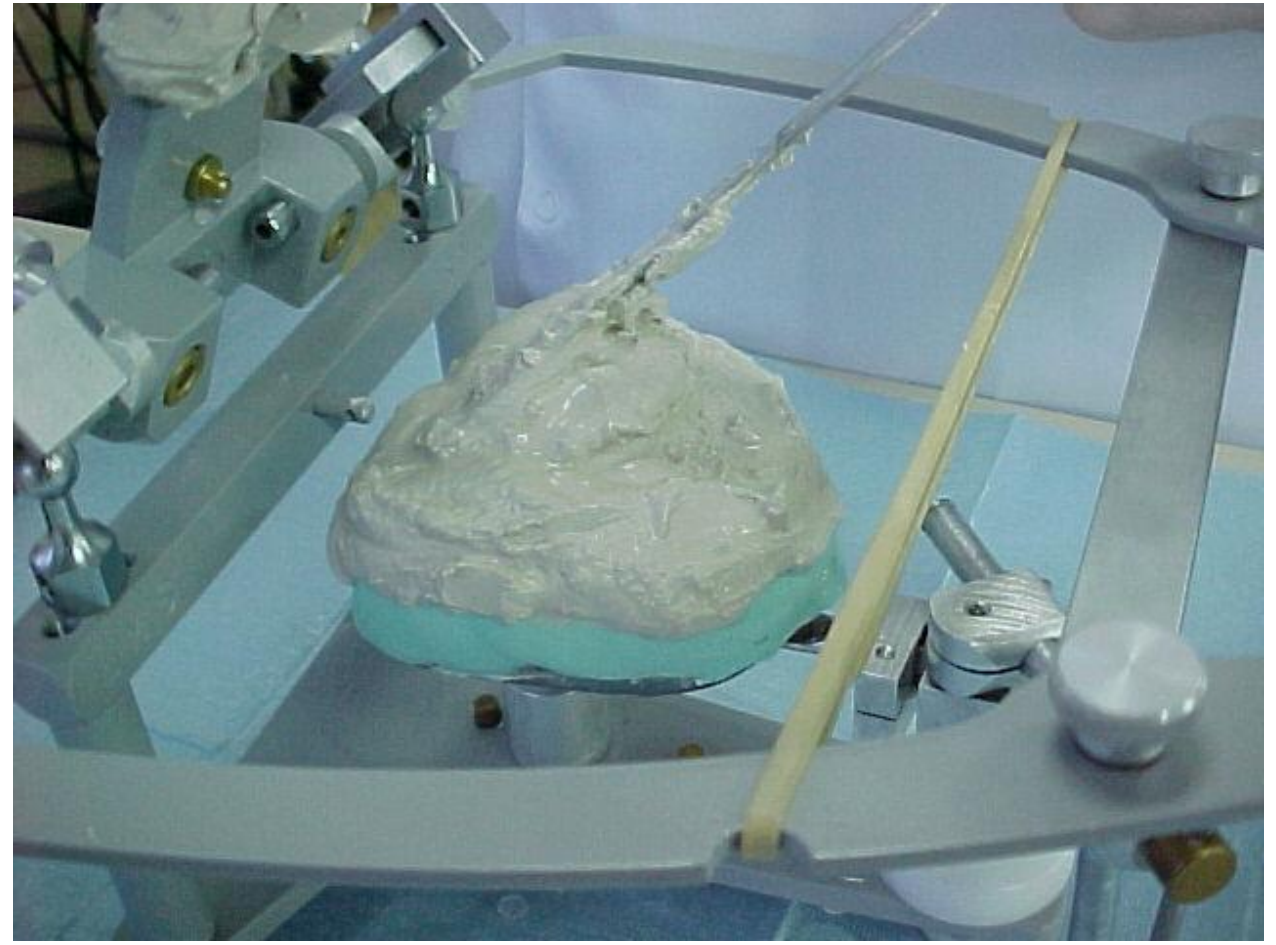

Figura 4.49 - Na seqüência, coloca-se o gesso sobre a porção previamente vazada do molde 
18 - o ramo superior do articulador foi abaixado sobre o suporte geral do arco facial, tomando-se o cuidado de posicionar a banda elástica sobre o ramo superior (Figuras 4.50, 4.51 e 4.52). A finalidade desse procedimento, como já mencionada anteriormente, é direcionar e controlar a expansão de presa do gesso lateralmente.

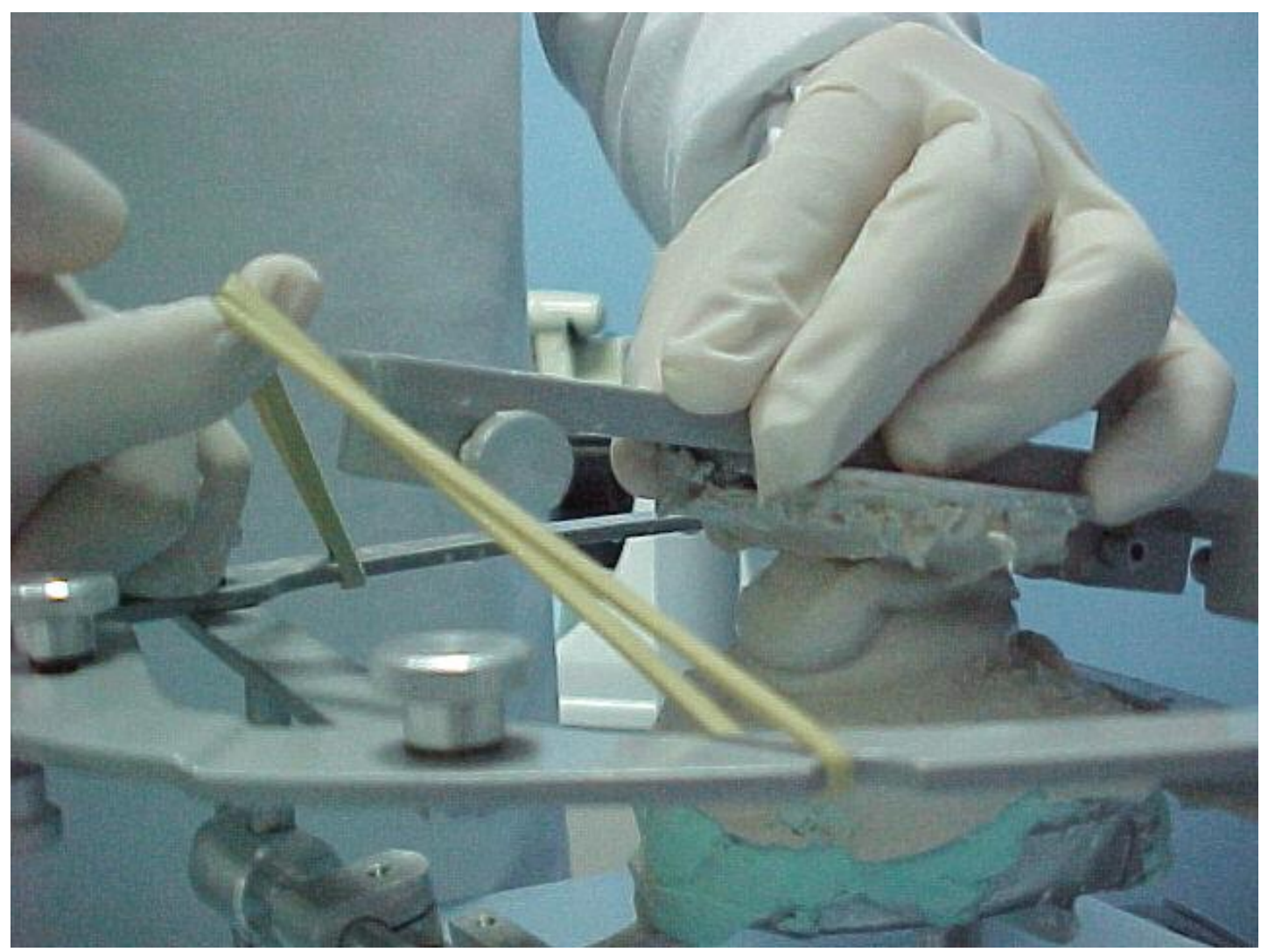

Figura 4.50 - Levanta-se a banda elástica e abaixa-se o ramo superior 


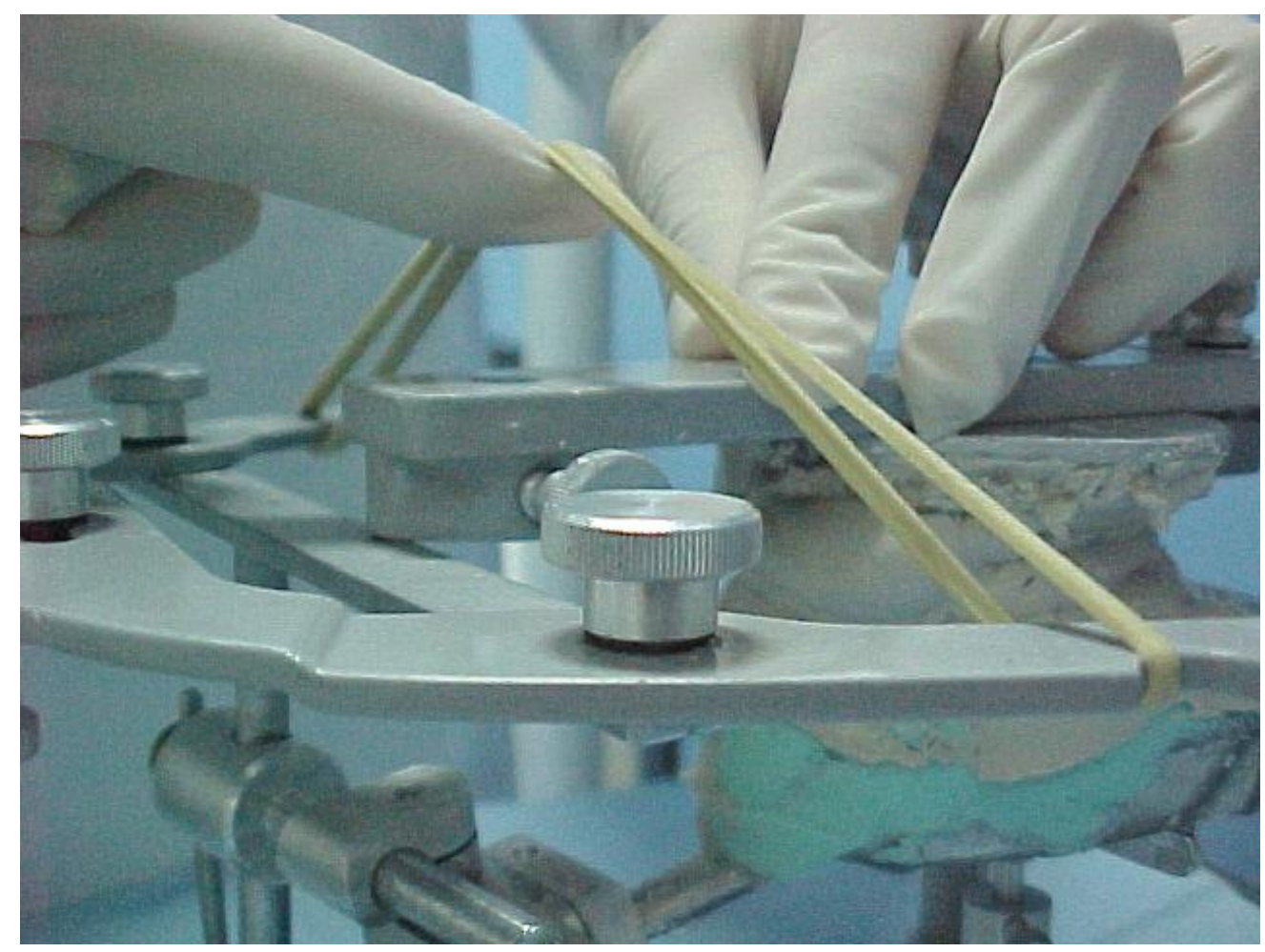

Figura 4.51 - 0 ramo superior deve encostar completamente sobre o suporte geral do arco facial

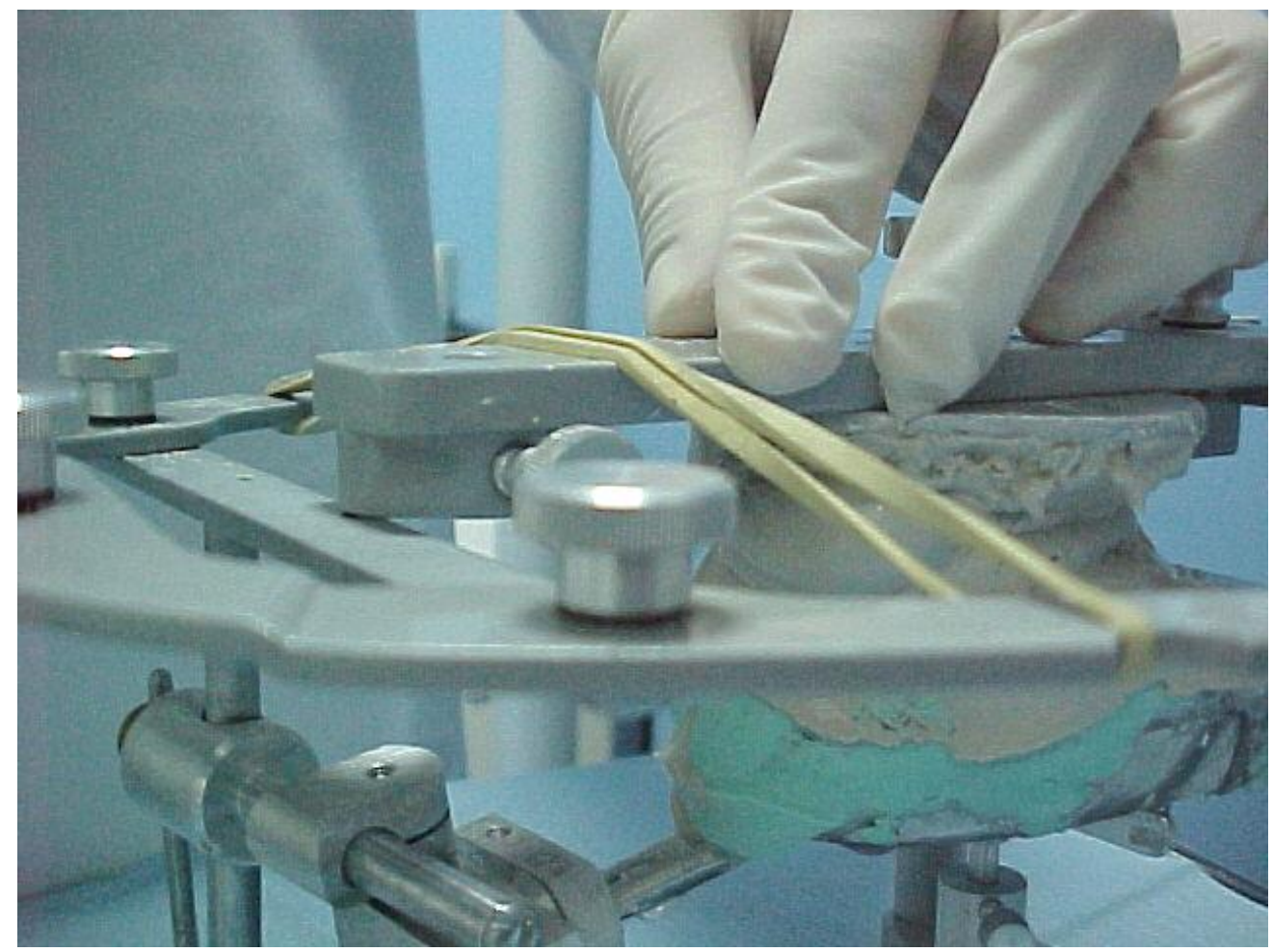

Figura 4.52 - A banda elástica é aplicada sobre o ramo superior do articulador 


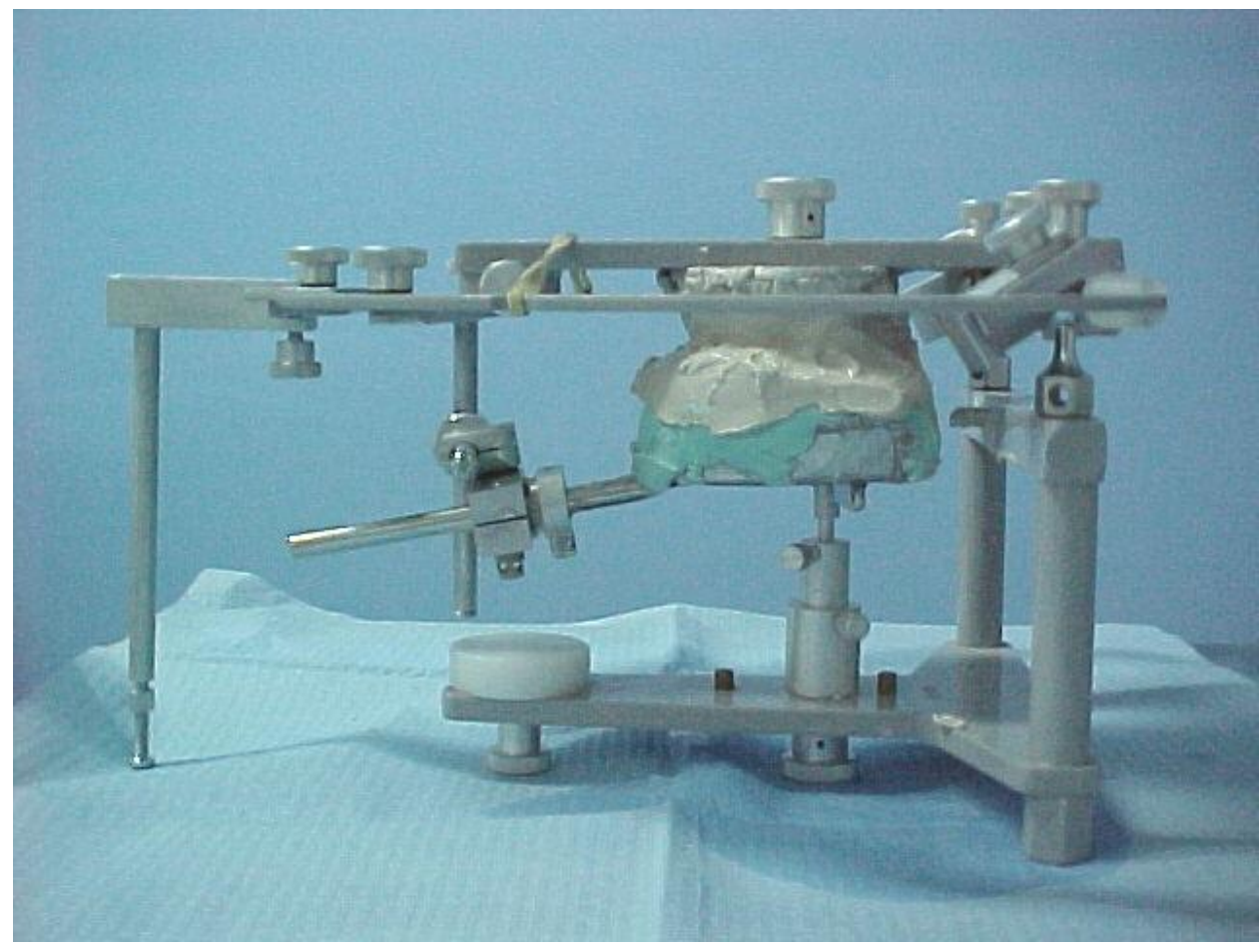

Figura 4.53 - Foi colocada uma pequena quantidade de gesso suficiente para complementar a fixação do futuro modelo no articulador

Seguiram-se, também nesta técnica, as orientações dos trabalhos de Grant (1963); Roraff \& Stansbury (1972); Dilts et al. (1978) e Peregrina \& Feil (1994) relacionadas a quantidade de gesso suficiente para permitir a complementação da transferência do molde ao articulador, minimizando a possibilidade de expansão de presa do gesso, circunstância que iria alterar a posição do modelo de gesso (Figura 4.53).

19 - após a cristalização do gesso, o arco facial foi removido do articulador e, em seguida, o modelo também foi retirado. Uma nova camada de gesso foi colocada para melhorar a fixação do modelo à placa de montagem. 


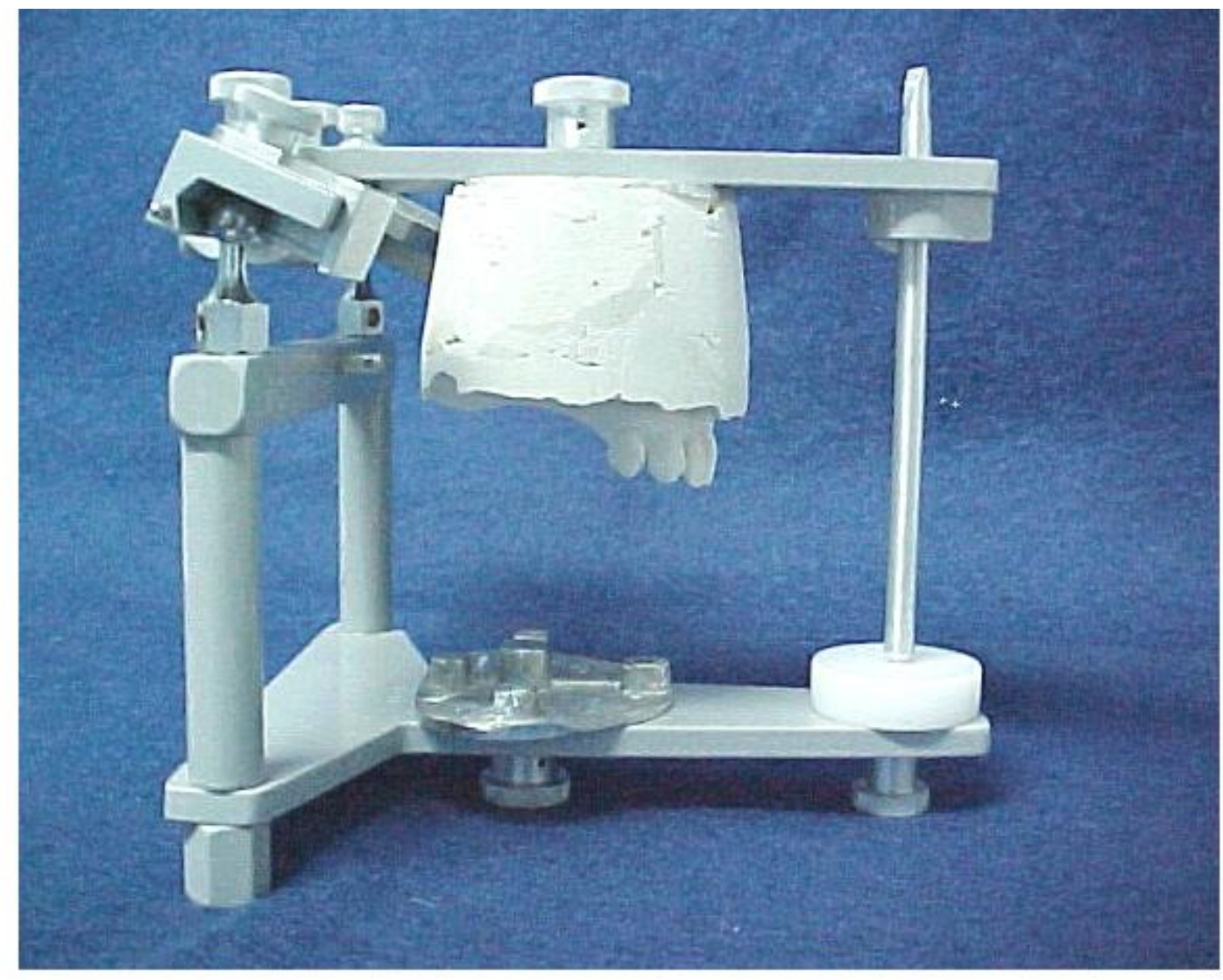

Figura 4.54 - Modelo de gesso montado em articulador pela técnica de transferência direta (Técnica Zanetti)

Foi dado um acabamento final do modelo em recortador de gesso (Figura 4.54).

Dessa forma foram obtidos todos os modelos de gesso utilizados nessa pesquisa (Figuras 4.55 e 4.56 ). 


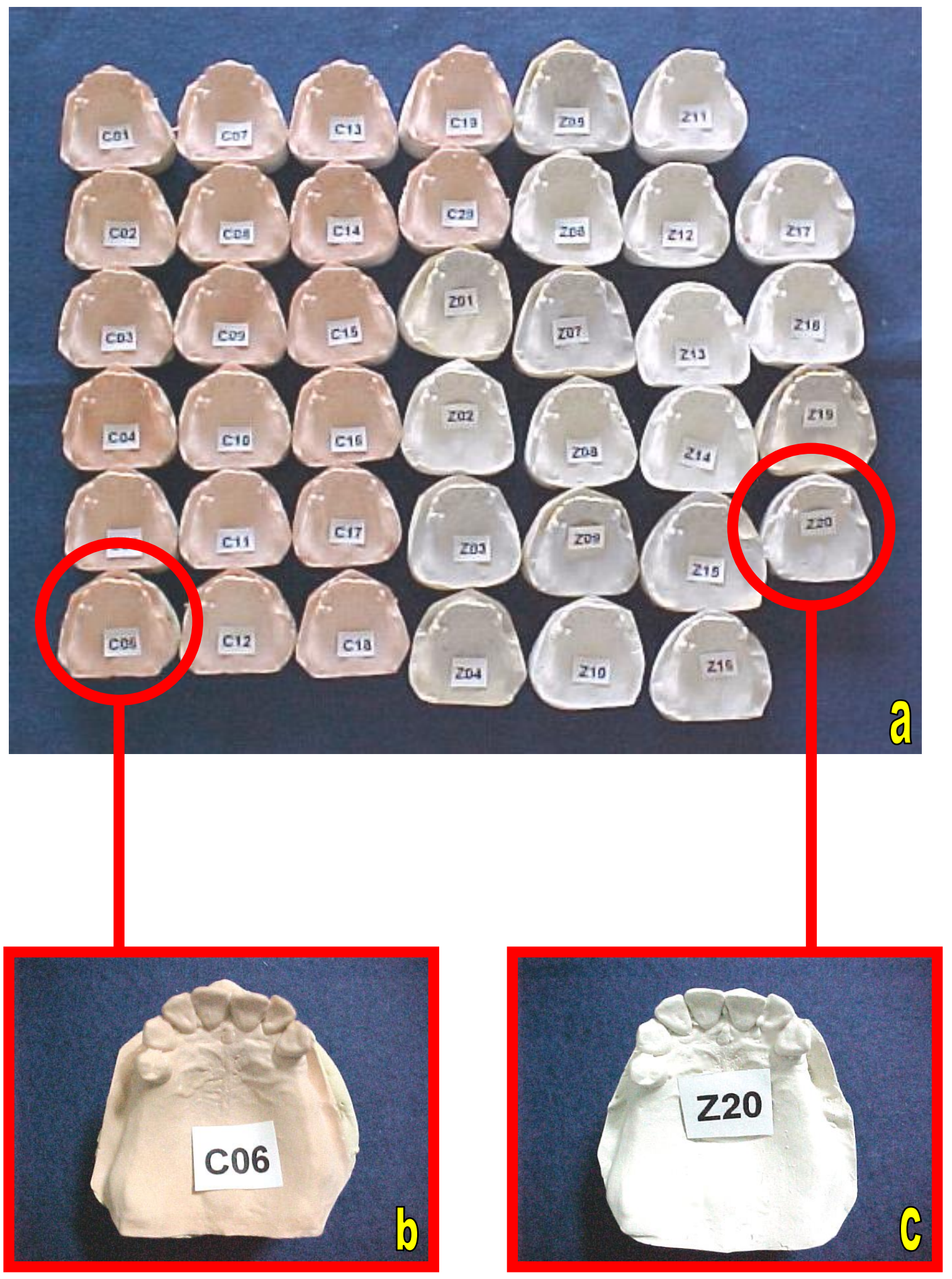

Figura 4.55 - (a) término da confecção dos modelos convencionais e de transferência direta (Zanetti); (b) detalhe do modelo convencional e, (c) detalhe do modelo obtido pela técnica Zanetti 


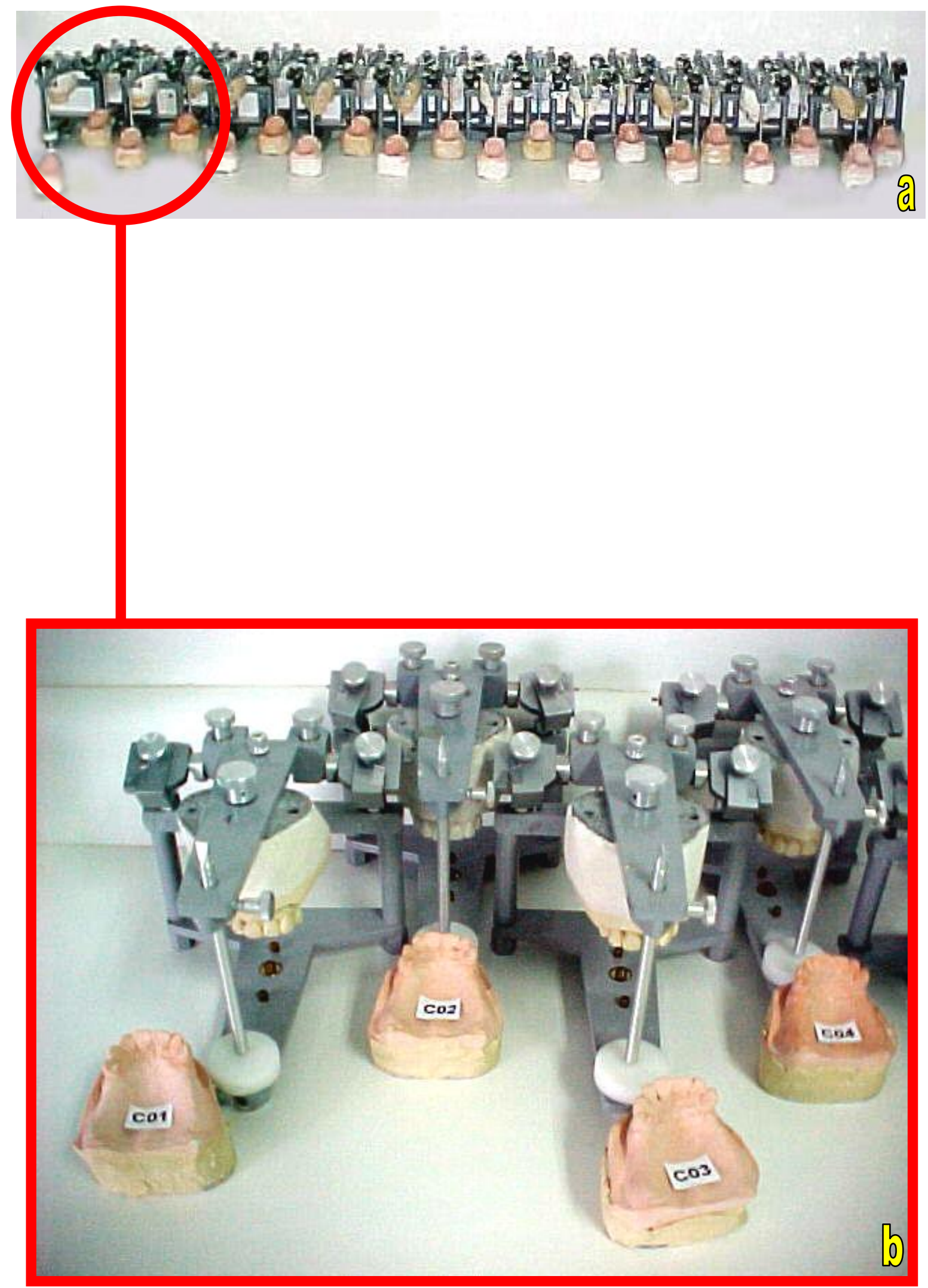

Figura 4.56 - (a) montagem dos modelos nos articuladores e, (b) no detalhe, os modelos da técnica Zanetti prontos para serem fotografados nos articuladores 


\subsubsection{Metodologia para análise das imagens}

A metodologia utilizada nesse estudo baseou-se nos trabalhos de Gross et al. (1990) e Ellis III et al. (1992) que analisaram a precisão de montagem dos modelos de gesso em articulador. Os autores utilizaram, respectivamente, métodos comparativos por meio de traçados cefalométricos sobre uma telerradiografia e nas fotografias dos modelos montados em articuladores e, também, um compasso comum para registrar o ângulo formado entre o plano oclusal e o de Frankfurt na radiografia do paciente e compará-lo com o ângulo entre o plano oclusal do modelo de gesso e o ramo superior do articulador.

Segundo Ferreira (2001) os traçados cefalométricos podem ser realizados manualmente ou com auxílio do computador.

No presente estudo, os traçados foram realizados manualmente, por meio de um esquadro e um transferidor, na telerradiografia e nas fotografias digitais impressas em papel fotográfico e, posteriormente, todos esses dados foram digitalizados e analisados no computador.

\subsubsection{Obtenção e digitalização da telerradiografia em norma lateral}

Utilizou-se o aparelho Orthopantomograph OP100 - Orthoceph OC100 (Instrumentarium Imaging Inc., Finland) com distância foco-objeto de 15,20cm, para a obtenção de uma telerradiografia em norma lateral da paciente com o arco facial ajustado em sua face pelo método convencional, que utiliza o garfo do arco para sua 
aplicação. Tomou-se o cuidado de evitar um erro de paralaxe na imagem do arco facial, assim somente o aspecto lateral do arco (e não o superior ou inferior) ficou visível na telerradiografia.

A finalidade dessa radiografia foi obter o ângulo entre os traçados dos planos oclusal e de Frankfurt, que serviu de parâmetro para as medições em computador que foram realizadas nas fotografias digitalizadas (Figura 4.57).

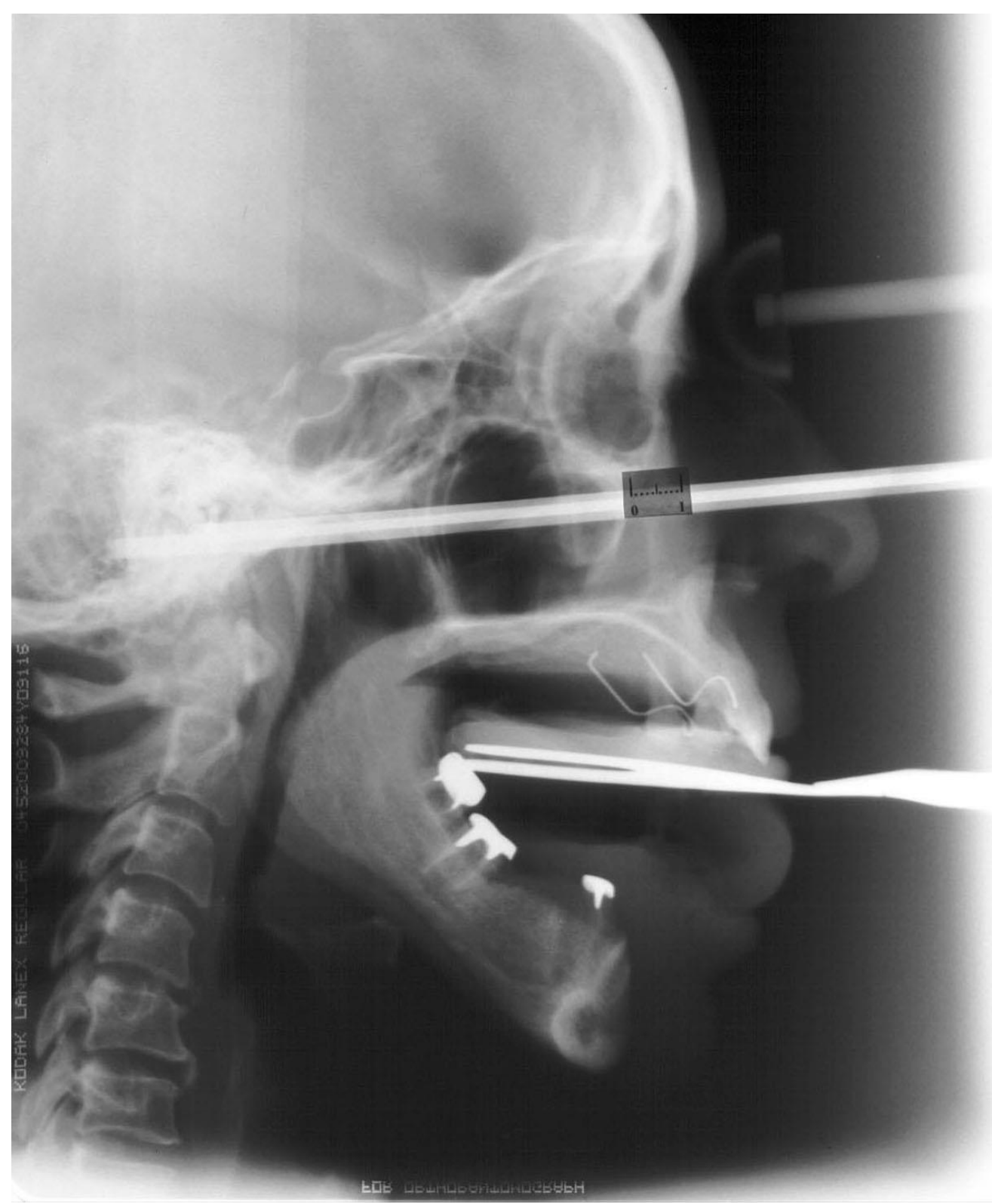

Figura 4.57 - Telerradiografia em norma lateral tomada com o arco facial em posição na face da paciente. Todo cuidado foi dado para que não ocorresse um erro de paralaxe em relação ao arco 
A telerradiografia foi obtida com um filme Kodak T-Mat (Eastman Kodak Co., USA) de tamanho $20 \times 25 \mathrm{~cm}$. O traçado foi realizado sobre o papel ultraphan (Dentaurum, Germany) colocado sobre o filme radiográfico, da seguinte maneira: inicialmente foi traçada uma linha sobre a porção superior mais radiopaca da imagem do arco facial, que corresponde ao plano de referência horizontal (Frankfurt) da paciente. Em seguida foi realizado outro traçado desde a imagem da porção mais proeminente do incisivo central superior direito, até a porção mais proeminente do segundo premolar superior direito, que corresponde ao plano oclusal da paciente. Esse traçado foi então transferido, com auxílio de um esquadro e um transferidor, com a finalidade de permitir sua intersecção com a linha do arco facial dentro dos limites da telerradiografia (Figura 4.58, seta $a$ ).

Antes da digitalização dessa imagem, a telerradiografia foi calibrada empregando-se uma régua de 01 centímetro (Figura 4.58, seta $b$ ), que foi colada paralelamente sobre a imagem do arco facial imediatamente acima da imagem do segundo premolar superior direito. Esse procedimento será analisado mais adiante no item 4.4.5.3.

Em seguida foi digitalizada por meio de um scanner de mesa Genius ${ }^{\circledR}$ colorpage CS modelo FS 1130 (Genius Scan Co., Taiwan), acoplado a um computador do tipo desktop (compatível com IBM) de 64MB de memória RAM e com processador Pentium ${ }^{\circledR}$ MMX de 133Mhz. Esse equipamento utilizou um editor de fotografia (Photoimpact ${ }^{\mathrm{TM}} 3.0 \mathrm{SE}$, Ulead Systems, Inc. Int., USA) que processou a imagem captada pelo scanner no formato JPEG de $837 \mathrm{~KB}$, compatível com a plataforma do Windows ${ }^{\circledR} 98$ (Microsoft Co., USA) e foi gravada no disco rígido do computador para posterior análise num software específico. 


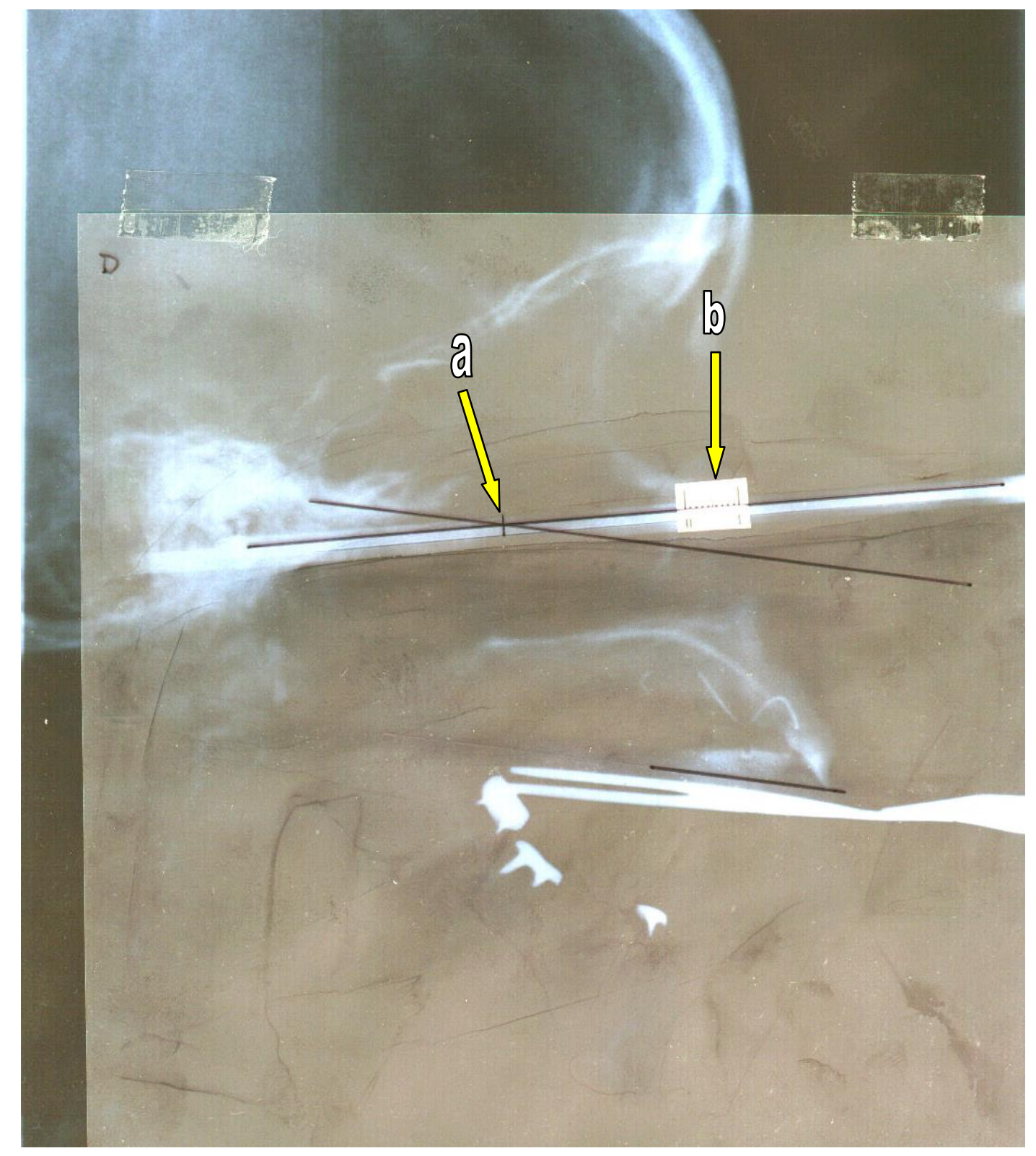

Figura 4.58 - Telerradiografia em norma lateral digitalizada com os traçados dos planos de referência horizontal (arco facial) e oclusal com a intersecção sobre o arco (a) e régua de calibragem de $1 \mathrm{~cm}(b)$

\subsubsection{Digitalização das imagens dos modelos de gesso montados nos articuladores}

Após a efetivação das montagens nos articuladores pelas duas técnicas, os modelos de gesso foram fotografados com a câmera digital Mavica ${ }^{\circledR}$ modelo MVC- 
FD73 (SONY da Amazônia Ltda., Brasil) que utiliza disquetes magnéticos de 3.5" (90mm) de dupla face e alta densidade com 1.44MB (megabytes) de capacidade para armazenar as imagens.

A exposição fotográfica dos modelos de gesso montados nos articuladores foi padronizada para a obtenção das imagens. O ramo inferior do articulador foi fixado numa bancada com cola SuperBonder ${ }^{\circledR}$ (Loctite Brasil Ltda., Brasil) com o lado direito voltado para a câmera e com um fundo azul para melhorar a definição dos limites da imagem do modelo.

A câmera foi montada num tripé (modelo V-0540, AMBICO Co., USA) com seu corpo paralelo ao plano sagital mediano do articulador e numa distância focal fixa de 15,20cm (a mesma do aparelho de telerradiografia). A câmera e o ramo superior do articulador foram relacionados horizontalmente usando-se um nível de bolha. A altura da câmera $(94 \mathrm{~cm})$ foi ajustada de maneira a evitar um erro de paralaxe, assim somente o aspecto lateral do ramo superior do articulador (e não o superior ou inferior) ficou visível na tela de cristal líquido da câmera. Apenas o ramo superior do articulador, com o modelo de gesso montado por meio de seu arco facial, foi trocado para a obtenção das imagens. De maneira idêntica a realizada na telerradiografia, todos os ramos superiores foram calibrados com uma régua de 01 centímetro, colada paralelamente na lateral do ramo e imediatamente acima da posição do segundo premolar superior direito (Figura 4.59, seta $b$ ). Para cada modelo de gesso, o articulador recebeu uma identificação numérica sobre o poste direito do ramo inferior de C01 a C20 para a técnica convencional e, de Z01 a Z20 para a técnica de transferência direta. O procedimento de calibração das fotografias com uma medida conhecida $(1 \mathrm{~cm})$, será analisado no item 4.4.5.3. 
As fotografias foram realizadas utilizando-se a resolução máxima da câmera no modo de gravação JPEG (Joint Photographic Experts Group) fine de 640 X 480 pixels (unidade básica da imagem digitalizada), em quatro disquetes com aproximadamente dez imagens de 78KB de tamanho (em média).

Na seqüência, as fotografias digitais dos modelos foram impressas no tamanho $6,5 \times 8,5 \mathrm{~cm}$ em papel revestido branco fosco de tamanho A4 (Ripax Ink Jet de $21 \mathrm{X}$ 29,7cm, RIPASA S. A., Brasil) com qualidade fotográfica de 720dpi (pixels por polegada) em impressora de jato de tinta colorida HP modelo Deskjet $^{\circledR}$ 710C (Hewlett-Packard Co., USA).

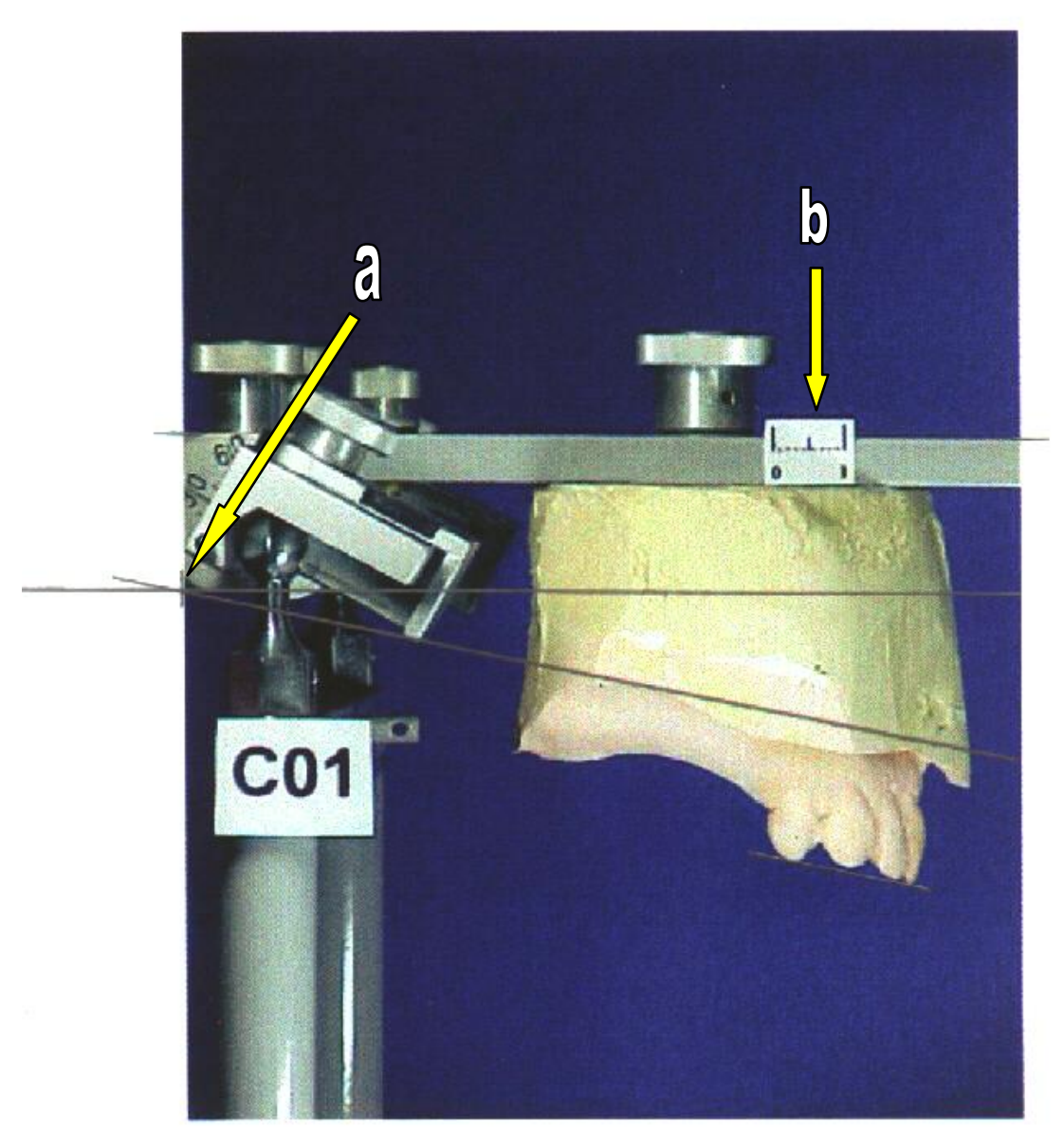

Figura 4.59 - Imagem digitalizada mostrando a intersecção dos traçados na borda esquerda da fotografia (a) e a régua de calibragem de $1 \mathrm{~cm}$ aplicada sobre o ramo superior do articulador $(b)$ 
Com a finalidade de padronizar e facilitar a visualização das mensurações, foram traçadas sobre as fotografias inicialmente uma linha paralela ao ramo superior do articulador, 1,2cm abaixo da porção superior do mesmo. Em seguida, de maneira idêntica a realizada na telerradiografia, foi traçada outra linha desde a imagem da porção mais proeminente do incisivo central superior direito, até a porção mais proeminente do segundo premolar superior direito, que corresponde ao plano oclusal da paciente. Esse traçado foi então transferido, com auxílio de um esquadro e um transferidor, com a finalidade de permitir sua intersecção com a linha do ramo superior junto à margem esquerda da fotografia (Figura 4.59, seta $a$ ) para facilitar a posterior mensuração do ângulo formado.

Com os traçados prontos, as fotografias foram digitalizadas com o scanner de mesa de maneira similar a realizada para a telerradiografia e armazenadas no disco rígido do computador no formato JPEG, com tamanho médio de 74KB.

\subsubsection{Análise das imagens no computador}

Para a análise do ângulo formado entre o plano oclusal e o de Frankfurt em todas as imagens digitalizadas, utilizou-se o software Image Tool versão 1.28 , da University of Texas Health Science Center at San Antonio (UTHSCSA), compatível com o Windows 98 (Microsoft Co., USA) instalado num computador multimídia portátil Compaq Presario ${ }^{\mathrm{TM}}$ série 1200 , com processador AMD-K6II de 450Mhz e 160MB de memória RAM. 
Trata-se de um programa de análise e processamento de imagens de uso público, desenvolvido pelos doutores C. Donald Wilcox, S. Brent Dove, W. Doss McDavid e David B. Greer, no Departamento de Ciência Diagnóstica Dental, do Centro de Ciência da Saúde da Universidade do Texas, San Antonio, Texas, EUA.

A análise que esse programa permite, inclui a função de medir ângulos e também a calibragem espacial que possibilitou trabalhar com a telerradiografia e as fotografias com o mesmo tamanho, isto é, ao permitir definir a unidade de referência (centímetro), foi possível corrigir a magnificência das imagens e obter todos os ângulos baseados na medida real dos objetos analisados.

Após a calibragem das imagens digitalizadas, as medições dos ângulos, realizadas pelo mesmo observador, foram repetidas por quatro vezes na telerradiografia (Figura 4.60), bem como em todas as imagens fotográficas (Figura 4.61), com intervalos de cinco minutos para não permitir a memorização dos pontos de aplicação da função de mensuração de ângulo, propiciando uma maior fidedignidade da análise.

O ângulo é desenhado clicando-se o botão esquerdo do mouse do computador em três pontos sobre a imagem digital: na intersecção entre os traçados e em dois pontos adicionais, um localizado sobre o plano do arco facial e outro sobre o traçado do plano oclusal.

O programa Image Tool fornece automaticamente o desvio padrão e o ângulo médio obtido. 


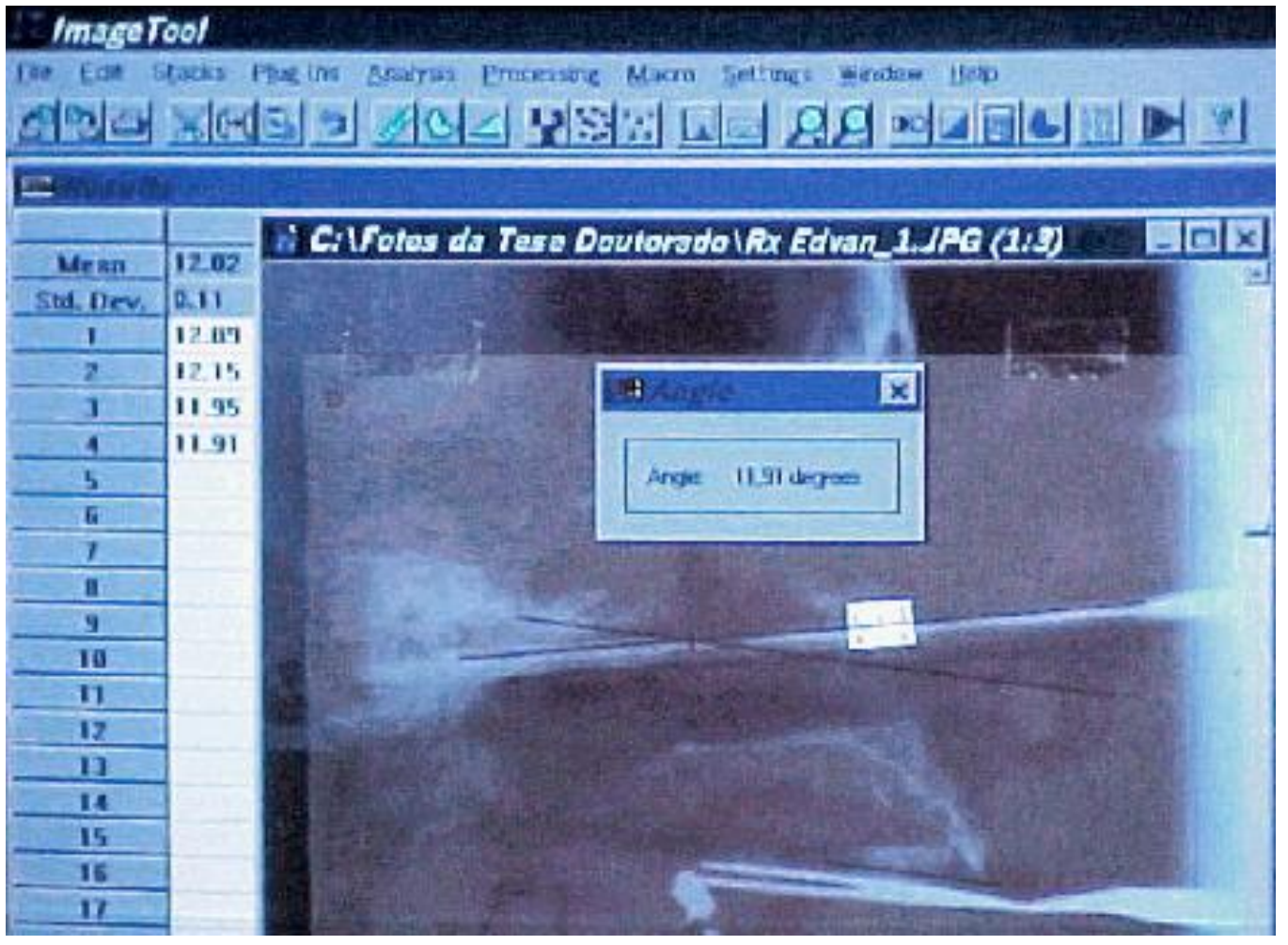

Figura 4.60 - Imagem digitalizada da telerradiografia em norma lateral sendo analisada pelo software Image Tool, após a calibragem espacial

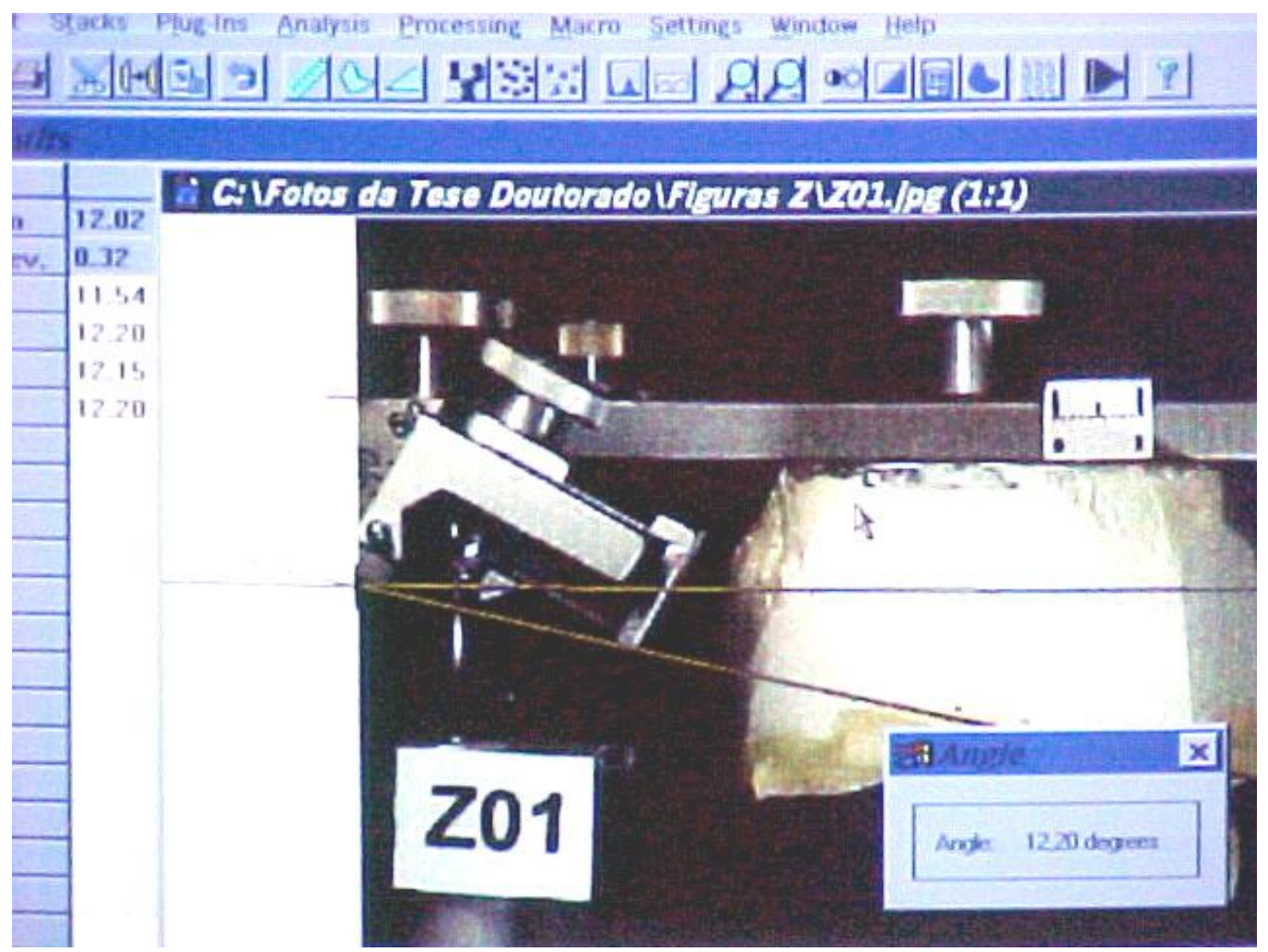

Figura 4.61 - Imagem digitalizada do modelo de gesso sendo analisada pelo software Image Tool, após a calibragem para correção da magnificência entre a telerradiografia e as fotografias 


\section{RESULTADOS}

Para avaliar a precisão de montagem dos modelos de gesso nos articuladores, foi utilizado um método comparativo por meio de traçados cefalométricos realizados manualmente, com auxílio de um esquadro e um transferidor, sobre uma telerradiografia e nas fotografias digitais impressas em papel fotográfico dos modelos montados nos articuladores e analisados num software específico em computador, o qual mediu o ângulo formado entre o plano oclusal e o de Frankfurt na radiografia da paciente e comparou-o com o ângulo entre o plano oclusal do modelo de gesso e o ramo superior do articulador. As medidas obtidas por meio desses traçados foram realizadas por um único operador.

A variável de interesse em ambas as técnicas foi o ângulo formado entre o plano oclusal e o de Frankfurt (Tabela 5.1). 


\subsection{Dados}

Tabela 5.1 - Ângulo (em graus) formado entre o plano oclusal e o de Frankfurt, segundo a telerradiografia em norma lateral da paciente

\section{Análise Angular}

\begin{tabular}{cc|c|c|c|c|c}
\hline & $\mathbf{1}$ & $\mathbf{2}$ & $\mathbf{3}$ & $\mathbf{4}$ & Média & Desvio Padrão \\
Telerradiografia & 12,09 & 12,15 & 11,95 & 11,91 & $\mathbf{1 2 , 0 2}$ & 0,11 \\
\hline
\end{tabular}

Os ângulos médios obtidos pela mensuração das imagens fotográficas digitais foram colocadas em duas tabelas, uma para a técnica convencional (Tabela 5.2) e outra para a técnica de transferência direta (Tabela 5.3). 
Tabela 5.2 - Ângulo (em graus) formado entre o plano oclusal e o ramo superior (plano de Frankfurt) do articulador, segundo os modelos montados pela técnica convencional

\begin{tabular}{|c|c|c|c|c|c|c|}
\hline \multicolumn{7}{|c|}{ Análise Angular } \\
\hline Modelos & 1 & 2 & 3 & 4 & Média & Desvio Padrão \\
\hline $\mathrm{C} 01$ & 11,17 & 11,17 & 11,85 & 11,15 & 11,33 & 0,34 \\
\hline $\mathrm{CO2}$ & 10,10 & 10,88 & 10,07 & 10,07 & 10,28 & 0,40 \\
\hline C03 & 7,81 & 7,21 & 8,51 & 8,51 & 8,01 & 0,63 \\
\hline C04 & 9,24 & 8,53 & 9,01 & 9,83 & 9,15 & 0,54 \\
\hline C05 & 6,95 & 6,17 & 6,17 & 6,94 & 6,56 & 0,45 \\
\hline $\mathrm{CO6}$ & 9,57 & 9,71 & 9,70 & 8,92 & 9,43 & 0,38 \\
\hline $\mathrm{CO7}$ & 4,96 & 4,19 & 5,03 & 4,13 & 4,58 & 0,48 \\
\hline C08 & 8,56 & 8,67 & 8,68 & 8,68 & 8,65 & 0,06 \\
\hline C09 & 7,01 & 7,12 & 7,00 & 7,12 & 7,06 & 0,07 \\
\hline C10 & 9,81 & 9,78 & 9,10 & 8,39 & 9,27 & 0,67 \\
\hline C11 & 6,19 & 6,26 & 5,57 & 6,26 & 6,07 & 0,33 \\
\hline C12 & 10,52 & 11,31 & 11,18 & 11,16 & 11,04 & 0,35 \\
\hline C13 & 5,64 & 5,71 & 5,65 & 5,71 & 5,68 & 0,04 \\
\hline C14 & 8,01 & 8,62 & 8,75 & 8,75 & 8,53 & 0,35 \\
\hline C15 & 9,33 & 9,33 & 9,33 & 9,38 & 9,34 & 0,03 \\
\hline C16 & 11,31 & 11,28 & 11,12 & 11,31 & 11,26 & 0,09 \\
\hline C17 & 9,44 & 9,37 & 9,44 & 8,36 & 9,15 & 0,53 \\
\hline C18 & 8,78 & 8,12 & 8,12 & 7,45 & 8,12 & 0,54 \\
\hline C19 & 10,93 & 11,07 & 11,17 & 11,99 & 11,29 & 0,48 \\
\hline $\mathrm{C} 20$ & 8,42 & 7,72 & 8,52 & 8,41 & 8,27 & 0,37 \\
\hline
\end{tabular}


Tabela 5.3 - Ângulo (em graus) formado entre o plano oclusal e o ramo superior (plano de

Frankfurt) do articulador, segundo os modelos montados pela técnica de transferência direta

\begin{tabular}{|c|c|c|c|c|c|c|}
\hline \multicolumn{7}{|c|}{ Análise Angular } \\
\hline Modelos & 1 & 2 & 3 & 4 & Média & Desvio Padrão \\
\hline Z01 & 11,54 & 12,20 & 12,15 & 12,20 & 12,02 & 0,32 \\
\hline Z02 & 12,35 & 12,35 & 11,66 & 11,66 & 12,00 & 0,40 \\
\hline Z03 & 12,30 & 12,23 & 13,11 & 11,81 & 12,36 & 0,54 \\
\hline Z04 & 11,77 & 11,73 & 11,77 & 11,73 & 11,75 & 0,02 \\
\hline Z05 & 11,71 & 11,58 & 11,58 & 12,27 & 11,79 & 0,33 \\
\hline Z06 & 11,93 & 12,53 & 12,53 & 11,89 & 12,22 & 0,36 \\
\hline Z07 & 11,68 & 11,68 & 12,59 & 12,38 & 12,06 & 0,44 \\
\hline Z08 & 11,05 & 12,39 & 12,05 & 10,67 & 11,54 & 0,81 \\
\hline Z09 & 12,08 & 12,08 & 12,05 & 12,08 & 12,07 & 0,01 \\
\hline Z10 & 11,98 & 11,98 & 11,98 & 12,01 & 11,99 & 0,01 \\
\hline Z11 & 10,60 & 11,63 & 10,57 & 10,75 & 10,89 & 0,50 \\
\hline Z12 & 11,74 & 12,30 & 11,74 & 12,30 & 12,02 & 0,32 \\
\hline Z13 & 10,58 & 10,58 & 10,59 & 11,28 & 10,76 & 0,35 \\
\hline Z14 & 12,35 & 11,68 & 11,68 & 12,35 & 12,02 & 0,38 \\
\hline Z15 & 11,47 & 12,53 & 11,63 & 12,50 & 12,03 & 0,56 \\
\hline Z16 & 11,73 & 12,87 & 11,73 & 11,73 & 12,02 & 0,57 \\
\hline Z17 & 10,99 & 10,82 & 11,05 & 11,71 & 11,14 & 0,39 \\
\hline Z18 & 12,71 & 11,38 & 12,55 & 11,52 & 12,04 & 0,68 \\
\hline Z19 & 11,31 & 12,04 & 12,04 & 12,81 & 12,05 & 0,61 \\
\hline $\mathrm{Z} 20$ & 11,58 & 12,27 & 12,41 & 11,74 & 12,00 & 0,40 \\
\hline
\end{tabular}




\subsection{Análise estatística}

Com o objetivo de avaliar se o uso da média das medidas, obtidas segundo cada uma das técnicas, não poderia trazer algum viés nos cálculos, foi feito um teste do sinal (Altman, 1991). Para cada técnica foram construídos os resíduos obtidos da seguinte maneira: cada uma das medidas, de cada um dos modelos, foi subtraída de sua respectiva média, resultando assim em quatro valores para cada um dos modelos, o que no final totalizou o montante de 80 valores de resíduos. Os Gráficos 5.1 e 5.2 mostram a dispersão desses resíduos para cada técnica.

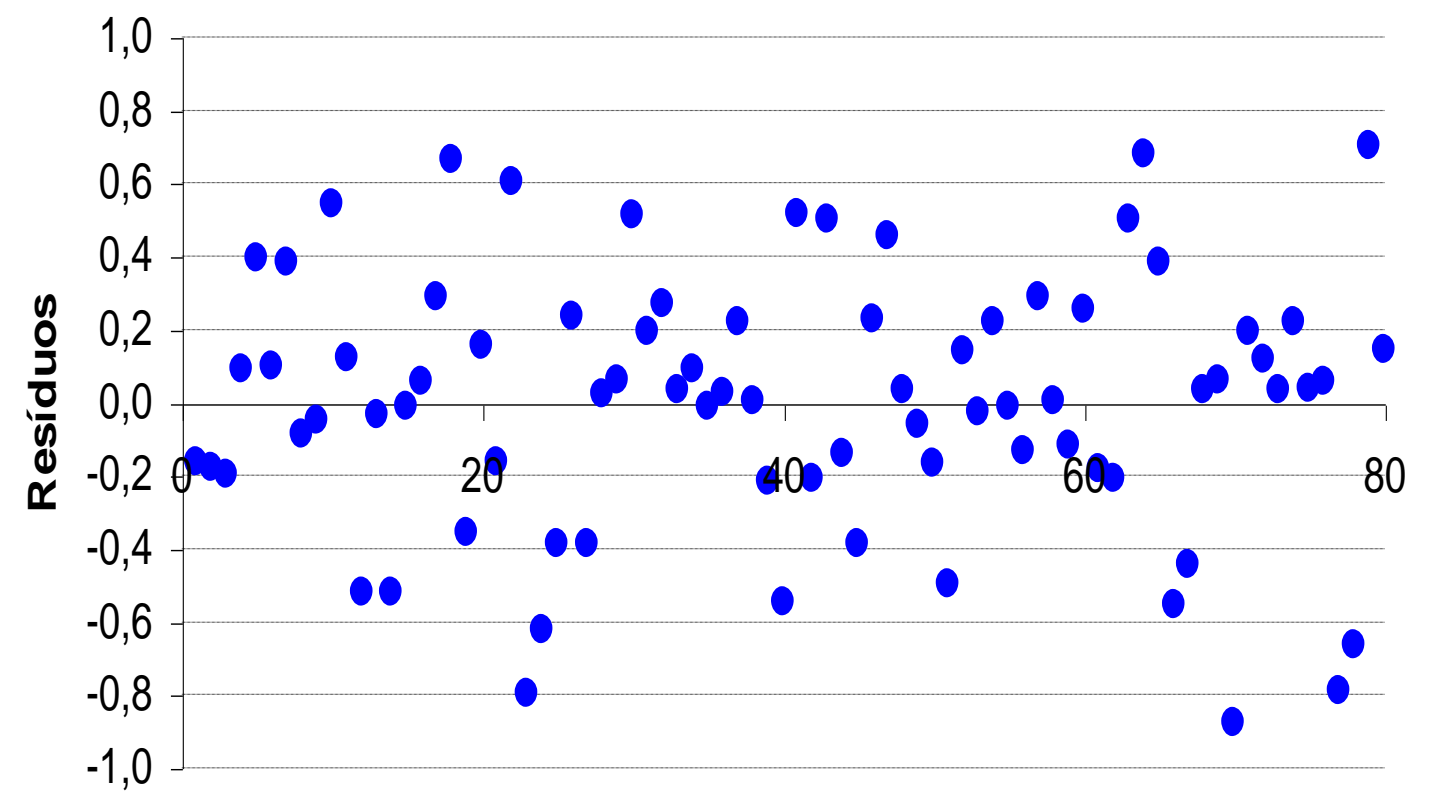

Modelos

Gráfico 5.1 - Gráfico de dispersão dos resíduos segundo os modelos da técnica convencional 


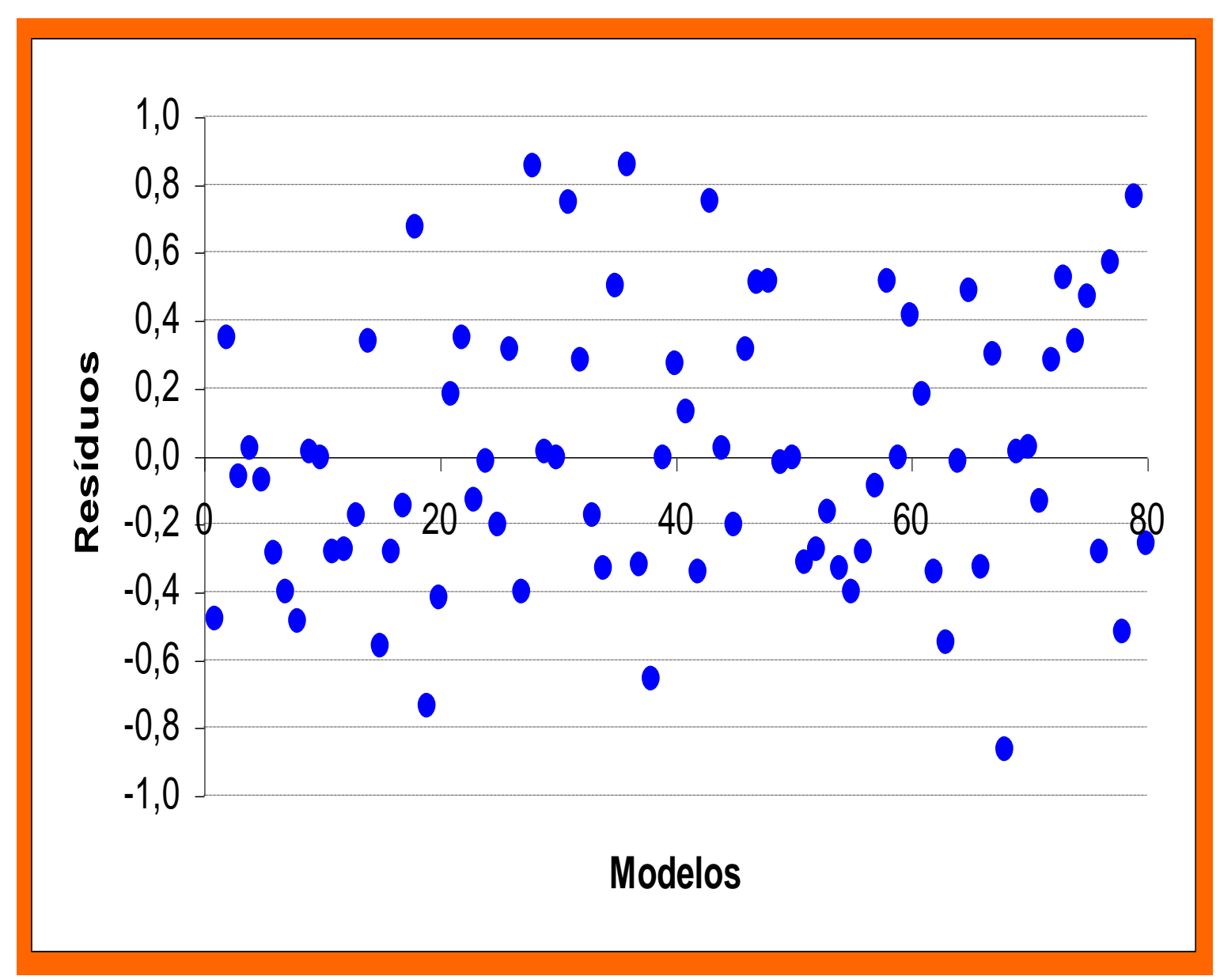

Gráfico 5.2 - Gráfico de dispersão dos resíduos segundo os modelos da técnica de transferência direta

Os Gráficos 5.3 e 5.4 apresentam uma análise da dispersão onde estão representados os valores médios dos ângulos entre o ramo superior (plano de Frankfurt) e o plano oclusal de cada modelo, segundo cada uma das técnicas, juntamente com o valor médio obtido da telerradiografia. 


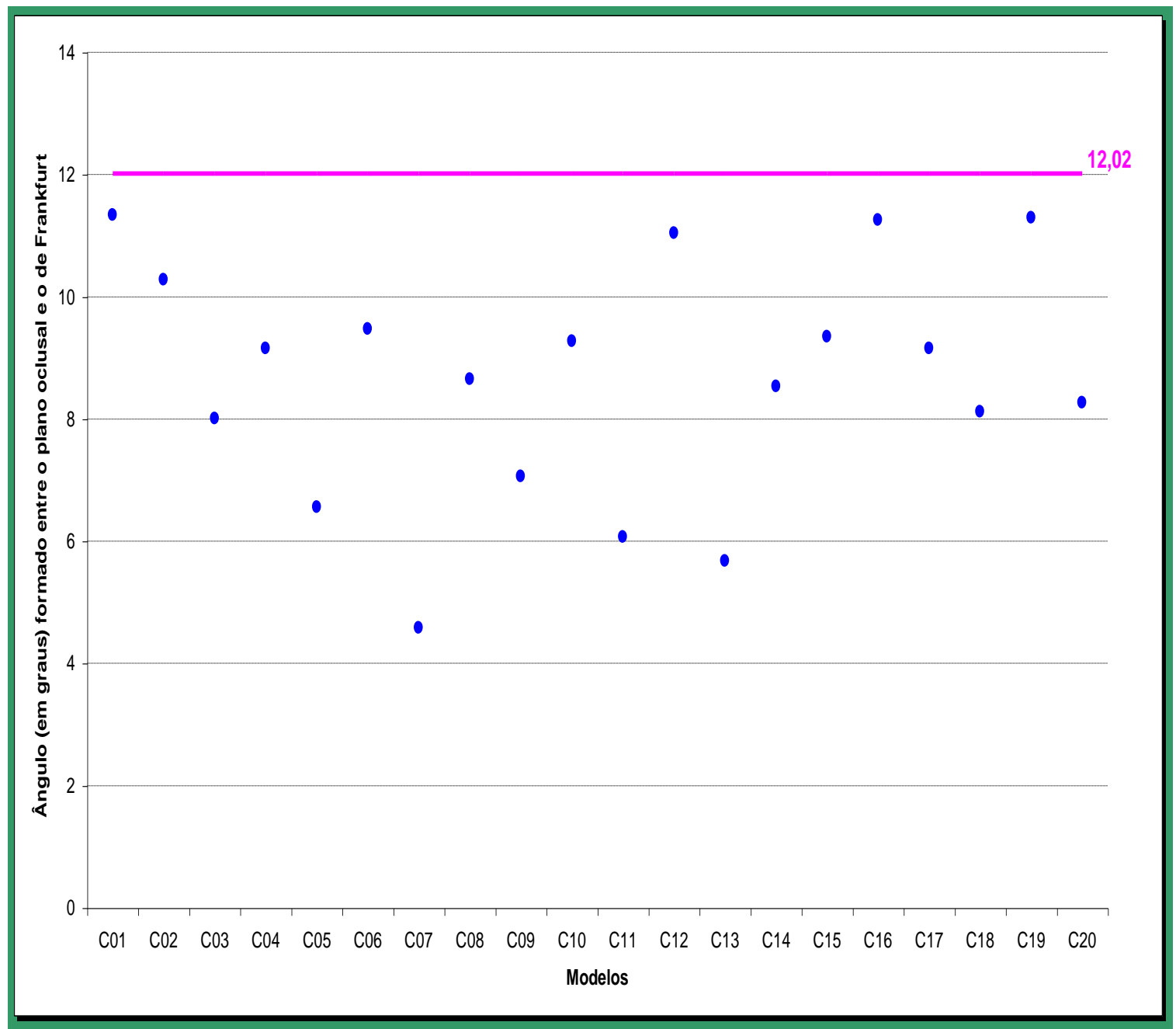

Gráfico 5.3 - Gráfico de dispersão dos valores médios dos modelos da técnica convencional 


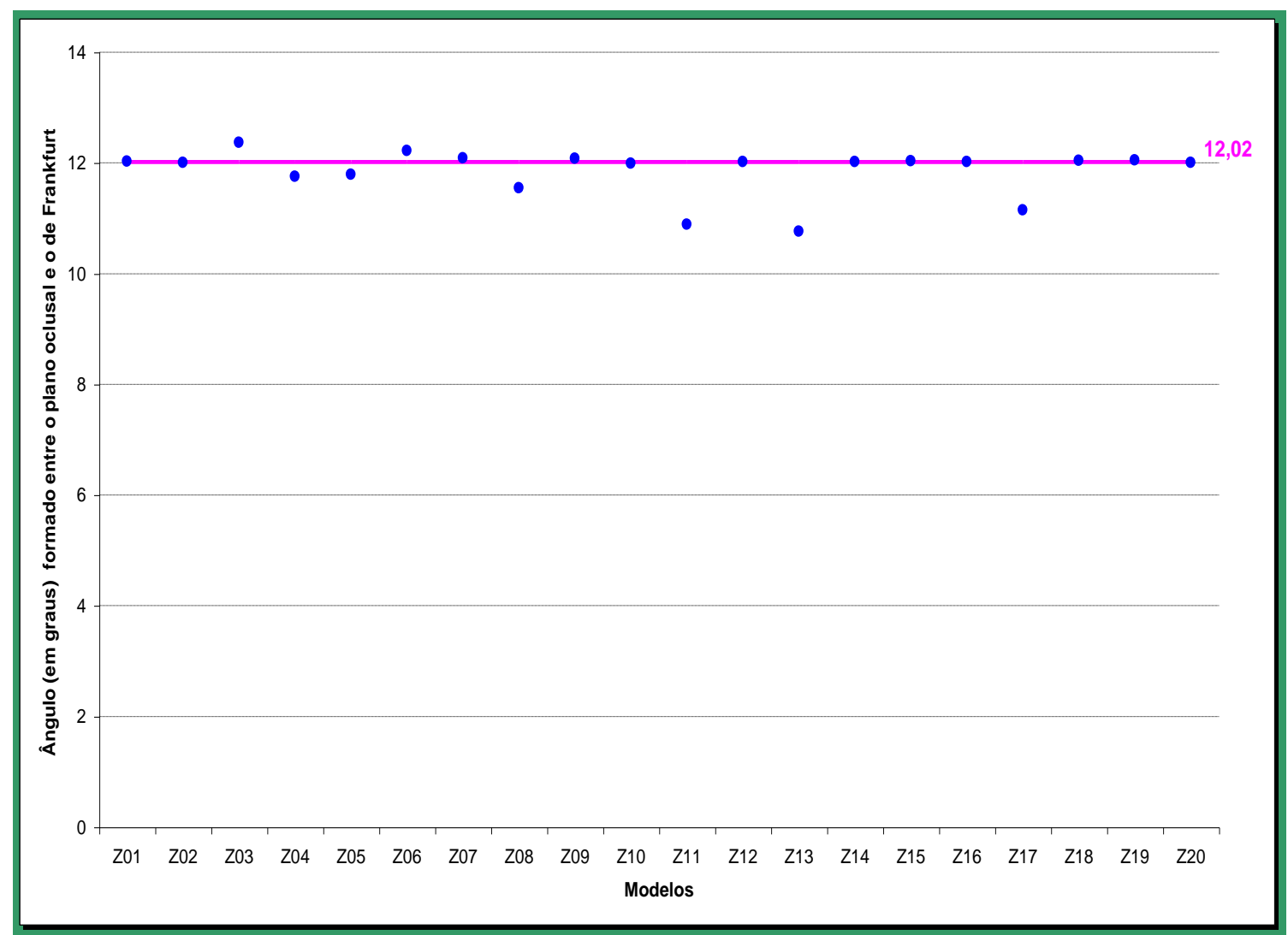

Gráfico 5.4 - Gráfico de dispersão dos valores médios dos modelos da técnica de transferência direta

Com o objetivo de quantificar e visualizar a magnitude das diferenças entre o valor obtido pelo modelo e aquele obtido na telerradiografia, foram construídos os Gráficos 5.5 e 5.6 que mostram, para cada uma das duas técnicas, as diferenças entre o valor obtido pela telerradiografia e o obtido por cada uma das duas técnicas. 


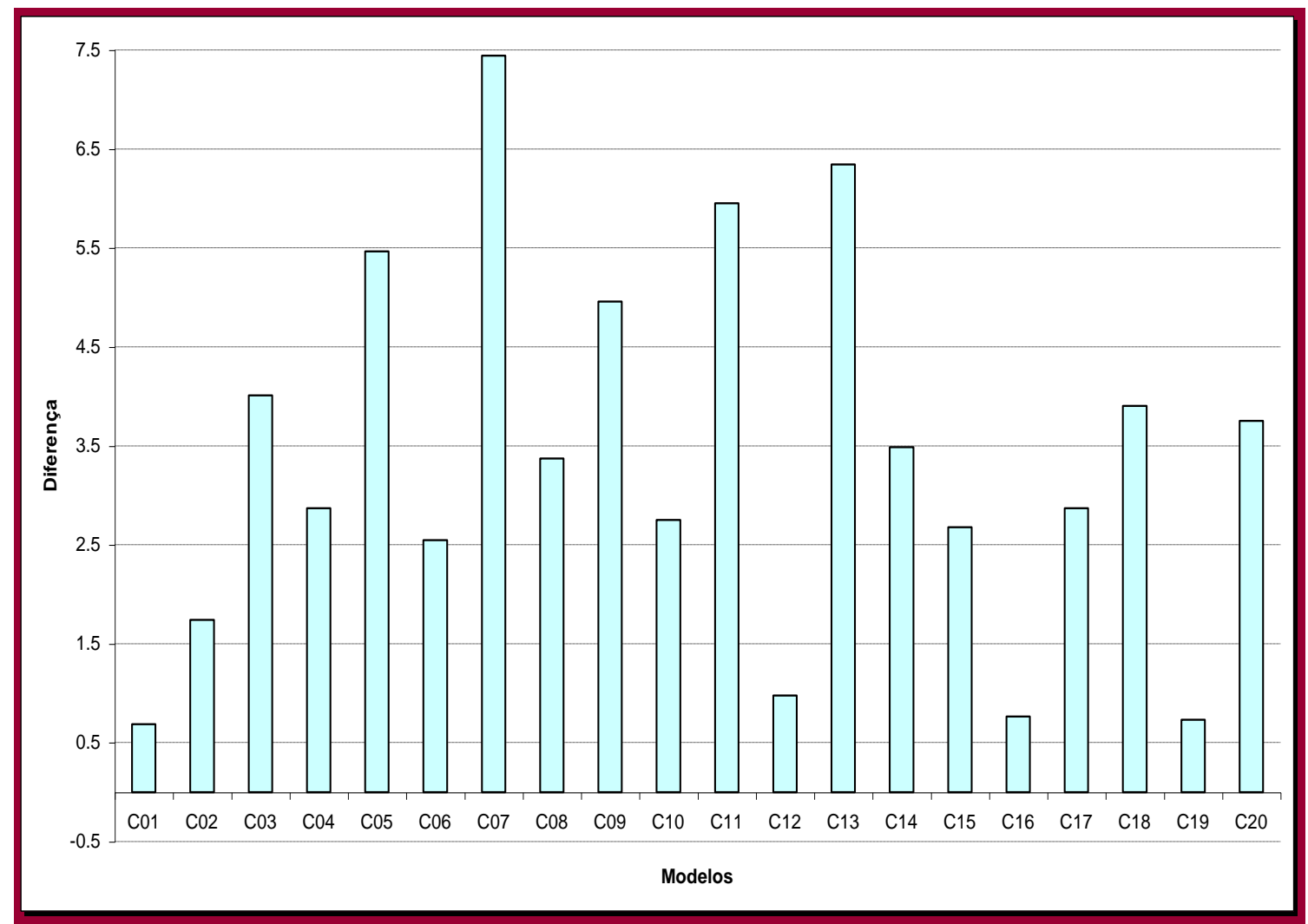

Gráfico 5.5 - Gráfico de barras das diferenças entre os valores obtidos da telerradiografia e os obtidos pela técnica convencional segundo cada modelo 


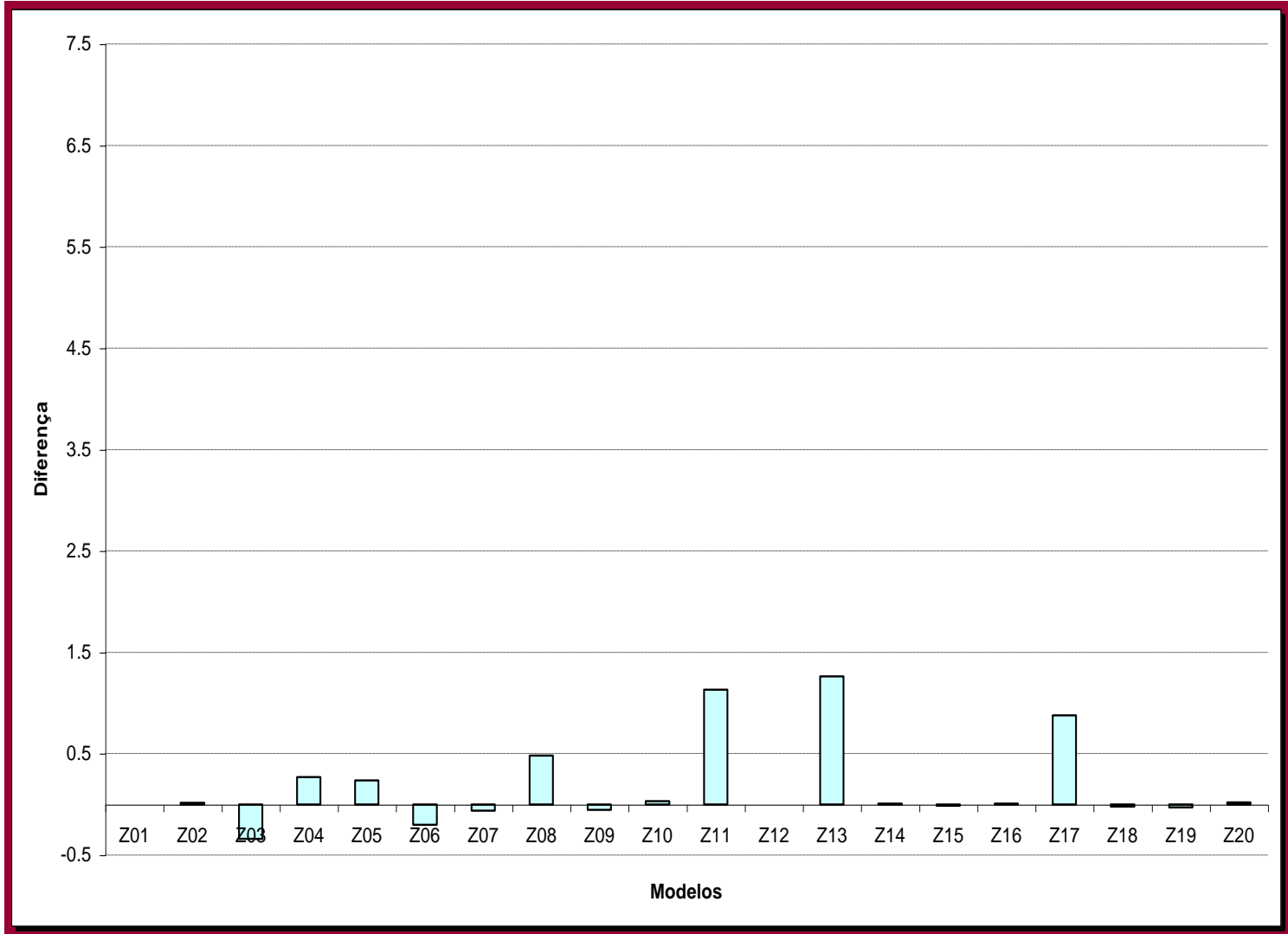

Gráfico 5.6 - Gráfico de barras das diferenças entre os valores obtidos da telerradiografia e os obtidos pela técnica de transferência direta segundo cada modelo

Com o intuito de avaliarmos se as diferenças observadas por meio da análise descritiva foram casuais, construímos intervalos de confiança com coeficiente de confiança de 95\% (Bussab \& Morettin, 1987) para verificarmos se, em média, o ângulo formado entre o plano oclusal e o de Frankfurt, segundo cada uma das técnicas, estavam contendo o ângulo obtido via telerradiografia. 
Para a técnica convencional o intervalo de confiança obtido foi de $\left[7,75^{\circ}\right.$; $\left.9,56^{\circ}\right]$, já para a técnica de transferência direta o intervalo encontrado foi de $\left[11,64^{\circ}\right.$; 12,04]. O Gráfico 5.7 mostra uma representação desses intervalos de confiança.

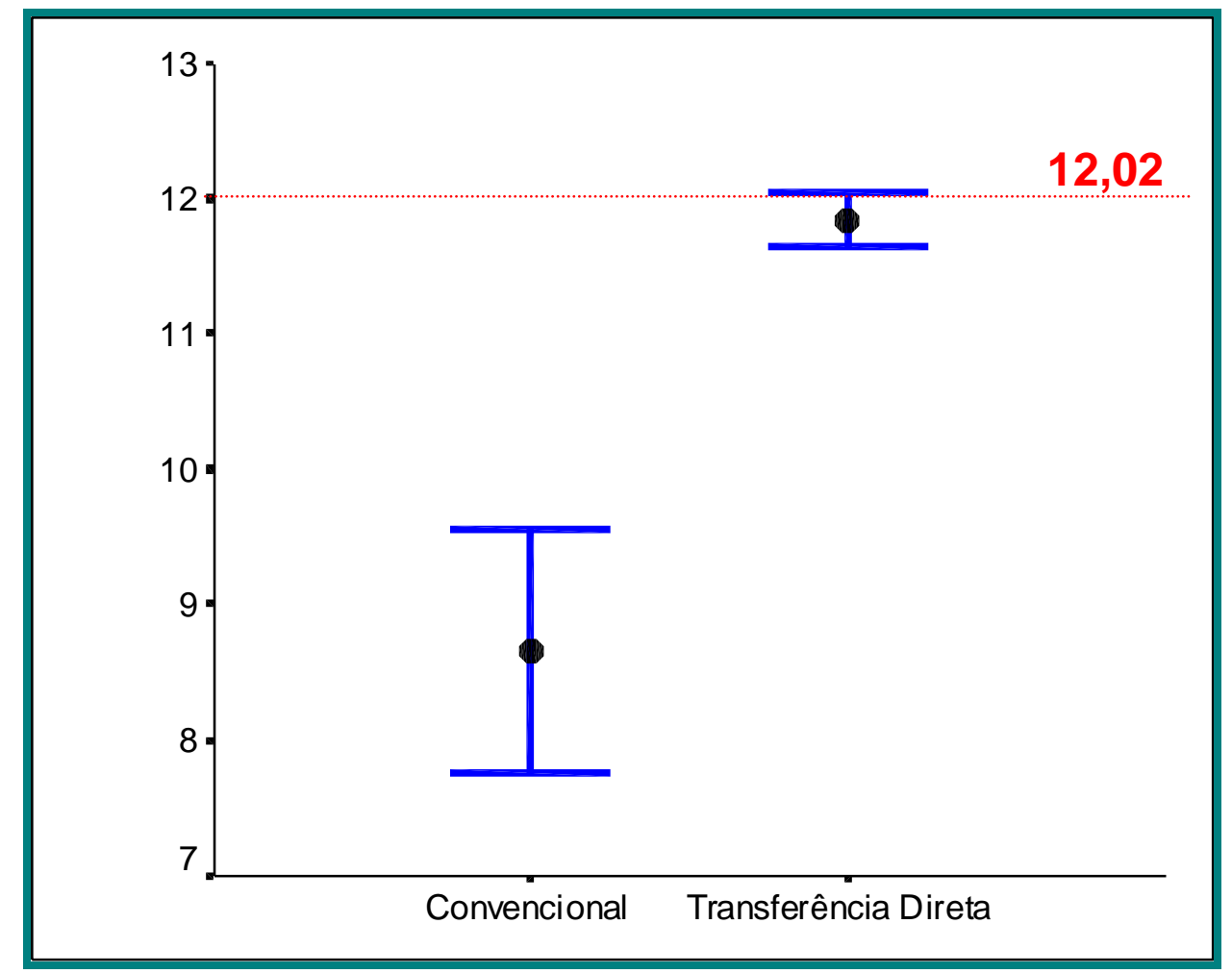

Gráfico 5.7 - Representação gráfica do intervalo de confiança a 95\% para cada uma das técnicas avaliadas

Foi feita uma análise complementar com o objetivo de comparar se as duas técnicas em questão produzem os mesmos valores do ângulo formado entre o plano oclusal e o de Frankfurt. Como não há sentido em comparar simplesmente os valores 
encontrados para cada técnica, então vamos comparar as duas técnicas com relação ao valor obtido via telerradiografia, ou seja, a variável utilizada para isso será a diferença entre o valor obtido pelo modelo e o obtido pela telerradiografia. O teste utilizado foi o teste $t$ de Student (Bussab \& Morettin, 1987). A diferença média obtida entre as diferenças das duas técnicas foi de $3,18^{\circ}$ (desvio padrão $=1,81^{\circ}$ ) a qual mostrou-se estatisticamente significante uma vez que o nível descritivo (Bussab \& Morettin, 1987) obtido foi $p<0.001$, isto é, menor do que o nível de significância adotado de $\alpha=0.05$. Ou seja, a técnica convencional produz, em média, diferenças de $2,34^{\circ}$ a $4,03^{\circ}$ maiores do que as produzidas pela técnica da transferência direta. 


\section{DISCUSSÃO}

Considerando-se toda a complexidade existente na montagem dos modelos de gesso nos articuladores, esse trabalho de investigação foi desenvolvido com a finalidade de se comparar duas técnicas de montagem: uma convencional, assim denominada por ser descrita por diversos pesquisadores e, outra de transferência direta do molde para o articulador, tendo em vista a capacidade de cada uma em relacionar, de forma precisa, o modelo de gesso superior aos elementos mecânicos do articulador, tal como a maxila se relaciona ao contexto craniofacial da paciente. Essa comparação, na verdade, poderia ser realizada analisando-se diversas variáveis presentes em todos os procedimentos necessários para se efetivar a montagem dos modelos de gesso no articulador. No entanto, nessa investigação, procurou-se restringir essas variáveis utilizando-se apenas uma paciente, um mesmo tipo de articulador e diversos operadores, como veremos a seguir.

A utilização de apenas uma paciente justifica-se pela necessidade de eliminar as variáveis anatômicas, de acordo com os trabalhos de Walker (1980); Chow et al. (1985); Zuckerman (1985); Tamaki et al. (1990) e Santos Jr. et al. (1996) que demonstraram a grande variabilidade entre a posição dos modelos montados em articulador e o eixo transversal de rotação dos côndilos da mandíbula, em virtude de variações anatômicas que podem ser encontradas nos pacientes, como por exemplo, uma assimetria facial que impossibilite a correta localização do eixo de rotação e, por 
consequiência, a montagem correta do arco facial em relação ao plano de Frankfurt do paciente.

Ricketts (1981), citado por Santos Jr. et al. (1996) demonstrou que em relação aos arcos faciais arbitrários de posicionamento no meato acústico externo, naturalmente são encontradas variações na anatomia do ouvido externo (localização do meato acústico externo) circunstância que poderia contribuir grandemente para a ocorrência de desvios no eixo de rotação da mandíbula, desposicionando assim o modelo de gesso superior.

Pode-se citar também, a grande variabilidade de tamanhos de modelos em virtude das diferenças anatômicas das arcadas que seriam encontradas entre diversos pacientes, que aumentaria muito a multiplicidade de fatores envolvidos nessa investigação, conforme ficou demonstrado no trabalho de Bowley \& Morgano (2001).

A decisão de utilizar-se uma paciente e um mesmo tipo de articulador, também baseou-se nos trabalhos de Weinberg (1961); Hart et al. (1983); Gordon et al. (1984) e Gross et al. (1990), os quais mostraram que os erros oclusais resultam de erros na localização do eixo de rotação, que afetam a localização dos modelos no articulador.

O emprego de apenas um tipo de articulador também baseou-se no trabalho de Goska \& Christensen (1988) que mostraram a grande variabilidade entre o eixo de rotação dos côndilos da mandíbula do paciente e as montagens com arco facial ao longo dos eixos tridimensionais $\mathrm{X}, \mathrm{Y}$ e $\mathrm{Z}$, quando compararam as posições do modelo de gesso no articulador utilizando quatro diferentes arcos faciais (Hanau kinematic, Hanau Face-bow, Hanau 159 de posicionamento no meato acústico e Hanau Twirl, também de posicionamento no meato). 
A utilização de vários operadores visou, propositadamente, não controlar o comportamento biomecânico dos dois sistemas de suporte de carga encontrados numa arcada desdentada posterior bilateral. Dessa maneira multiplicou-se sensivelmente as possibilidades de comparar-se a técnica convencional (onde esses dois sistemas atuam e dificultam seu controle) e a técnica de transferência direta (onde esses dois sistemas são mais facilmente controlados). Essa opção também pode ser fundamentada no trabalho de Zuckerman, 1985, que demonstrou que a precisão de montagem em articulador depende do método utilizado para localizar o eixo de rotação transversal dos côndilos da mandíbula, da precisão dos instrumentos utilizados para o registro desta posição e da habilidade e experiência do dentista no manuseio dos instrumentos. Gross et al. (1990) também empregaram mais de um operador em apenas um paciente.

O parâmetro utilizado nesta pesquisa foi o ângulo formado entre o plano de Frankfurt e o plano oclusal da paciente, sendo que os ângulos formados entre o ramo superior do articulador e o plano oclusal dos modelos montados na técnica convencional e na técnica de transferência direta do molde, foram comparados a ele.

De acordo com essa proposta, os resultados obtidos nesse estudo serão discutidos a seguir.

Analisando-se os Gráficos 5.1 e 5.2, pode-se notar que os valores dos resíduos encontram-se aleatoriamente distribuídos em torno dos valores de -1 a +1 sugerindo um não viés, isto é, não apresentam vício. O teste do sinal verifica se o número de resíduos positivos é estatisticamente igual ao número de resíduos negativos. Adotando-se um nível de significância $(\alpha)$ igual a 5\% (Bussab \& Morettin, 1987) verificamos uma não significância estatística tanto para a técnica convencional ( $p=$ 0.314) como para a técnica de transferência direta $(p=0.218)$, mostrando a não 
existência de viés em utilizar-se a média como uma medida resumo dos quatro valores obtidos para cada montagem.

Mediante essa informação, para toda a análise estatística foram utilizados o valor médio do ângulo (em graus) formado entre o plano oclusal e o de Frankfurt obtidos para cada um dos modelos em cada uma das técnicas. Apesar de tratar-se de uma medida em graus, como todos os seus valores encontram-se no primeiro quadrante (de 0 a 90 graus) não se faz necessária a utilização de metodologia específica para dados circulares.

Tomando-se o ângulo obtido pela telerradiografia como sendo a posição real da arcada superior da paciente, podemos notar por meio dos Gráficos 5.3 e 5.4 que os valores do ângulo obtido pela técnica convencional foram todos menores do que aquele da telerradiografia ao passo que para a técnica de transferência direta os valores obtidos encontram-se mais próximos do valor da telerradiografia.

Observando-se os Gráficos 5.5 e 5.6 pode-se notar que para a técnica de transferência direta as diferenças obtidas estão próximas de zero (média $=0,18^{\circ} \mathrm{e}$ desvio padrão $=0,43^{\circ}$ ), apresentando o valor $1,26^{\circ}$ como a maior diferença encontrada entre o valor obtido pela telerradiografia e o obtido pela transferência direta. Já para a técnica convencional a diferença média encontrada foi de $3,36^{\circ}$ (desvio padrão $=$ $\left.1,94^{\circ}\right)$

Ainda com relação aos Gráficos 5.5 e 5.6, parece que a técnica transferência direta permite um melhor posicionamento do modelo de gesso no articulador adotando-se a telerradiografia como a posição real da arcada superior do paciente.

Pela análise do Gráfico 5.7, podemos perceber que o valor obtido pela telerradiografia, que está sendo considerado como a posição real da arcada, encontrase contido somente no intervalo de confiança da técnica de transferência direta. Ao 
compararmos tanto o limite inferior $\left(7,75^{\circ}\right)$ quanto o limite superior $\left(9,56^{\circ}\right)$ do intervalo de confiança obtido pela técnica convencional, notamos que os valores encontrados são inferiores àquele que está sendo considerado como o nosso valor de referência $\left(12,02^{\circ}\right)$.

Esses resultados demonstram a influência da técnica nessa importante etapa do tratamento de um paciente, que é a montagem dos modelos de gesso em articulador.

Vale lembrar que para se proceder à uma análise oclusal, um adequado plano de tratamento ou mesmo a reabilitação de qualquer caso em Odontologia, necessita-se de uma tríade formada pelo exame clínico, exame radiográfico e modelos de gesso de ambas as arcadas correlatados de maneira adequada, sem a interferência neuromuscular (Thorp et al., 1978; Kotwal, 1979; Hockel, 1980; Beard \& Clayton, 1981; Chow et al., 1985).

De acordo com Pruden (1960); Weinberg (1963a); Hickey et al. (1967); Heartwell \& Rahn (1974); Henderson \& Steffel (1979); Tamaki (1981), Zanetti \& Ribas (1996, 1997); Costa (1998); Todescan et al. (1998); Turano \& Turano (1998); Costa et al. (1999) e Santos, Jr. (2000, informação verbal), o articulador é o dispositivo mecânico metálico ou quase totalmente metálico utilizado para relacionar os modelos de gesso da maxila e mandíbula e para representar as articulações temporomandibulares.

Teteruck \& Lundeen (1966) afirmaram que o uso de um articulador está na dependência de uma precisa transferência feita pelo arco facial.

A revisão da literatura apresentou uma similaridade muito grande entre os pesquisadores em relação à montagem do modelo de gesso superior em articulador semi-ajustável, particularmente no Whip Mix modelo 8500, utilizando o método arbitrário com o arco facial simples de posicionamento no meato acústico externo e o 
garfo ou forquilha contendo um meio macio de transferência do modelo para o articulador (Weinberg, 1961; Weinberg, 1963b; Teteruck \& Lundeen, 1966; Tamaki, 1971; Tanaka et al., 1975; Whitsett et al., 1977; Hockel et al., 1980; Walker, 1980; Hart et al., 1983; Shillingburg et al., 1983; Gordon et al., 1984; Todescan et al., 1998) o qual é descrito como um método aceitável para montagem dos modelos de gesso em articulador (Teteruck \& Lundeen, 1966; Fox, 1967; Hickey et al., 1967; Bonfante et al., 1974; Tanaka et al., 1975; Mohamed et al., 1976; Whitsett et al., 1977; Laing \& Wise, 1978; Hockel, 1980; Gross \& Gazit, 1985; Palik et al., 1985; Ellis III et al., 1992; Akerly, 1996; Zanetti \& Ribas, 1996, 1997; Costa, 1998 e Costa et al., 1999).

A literatura também demonstrou que esses aparelhos, mesmo apresentando certas limitações mecânicas (Aull, 1965; Hickey et al., 1967; Bellanti, 1973; Whitsett et al., 1977; Shillingburg et al., 1983; Whitbeck \& Ivanhoe, 1985; Desplats, 1986; Johnson \& Stratton, 1988; Malone \& Koth, 1991; Mohl et al., 1991; Todescan et al., 1998) possuem uma razoável precisão e, dependendo do tipo utilizado, conseguem uma eficiência de 75,5\% na localização do eixo terminal de rotação da mandíbula (Teteruck \& Lundeen, 1966; Parel, 1972; Whitsett et al., 1977; Shillingburg et al., 1983).

Utilizou-se a mesma técnica descrita na literatura para os articuladores semiajustáveis da marca Whip Mix modelo 8.500, visto que os disponíveis em nosso mercado, como por exemplo o Dent-Flex modelo 10.600 que foi empregado nessa pesquisa, possuem a mesma concepção de funcionamento do modelo americano.

Para ter-se idéia da problemática encontrada na montagem de modelos de gesso em articuladores, pode-se preceituar que as arcadas que apresentam grandes espaços protéticos ou extremidades livres, uni ou bilaterais, são as que apresentam um grau de complexidade muito grande na montagem em articulador e, 
consequentemente, na construção de próteses adequadas, devido a presença de duas vias de suporte, de naturezas diferentes, na sua sustentação: uma dentária, representada pelas fibras periodontais e outra fibromucosa, representada pela resiliência dos tecidos que recobrem o rebordo alveolar. Diversos pesquisadores mencionaram a diferença de comportamento entre dentes e fibromucosa diante das forças mastigatórias (Henderson \& Steffel, 1979; Zanetti \& Laganá, 1996; Zanetti \& Ribas, 1996).

Essas diferenças foram bem denotadas nos trabalhos de Thielemann (1938) citado por Rebossio (1963) e Biagi \& Elbrech (1955) que demonstraram a movimentação fisiológica dos dentes para dentro do alvéolo de $0,1 \mathrm{~mm}$, bem como os trabalhos de Fava (1956); Applegate (1959); Rebossio (1963); Henderson \& Steffel (1979); Zanetti \& Laganá (1996); Zanetti \& Ribas (1996) e Todescan et al. (1998) que, ao verificarem os valores médios da resiliência da fibromucosa em torno de 1 a $4 \mathrm{~mm}$, portanto dez a quarenta vezes mais que a movimentação do dente para dentro do alvéolo, demonstraram que dentes e fibromucosa são duas vias de transmissão de cargas mastigatórias com comportamentos biomecânicos bem diferentes.

No caso da arcada dentária de Classe I de Kennedy, utilizada nessa pesquisa, quando se emprega o método convencional de montagem em articuladores necessitase de no mínimo duas sessões clínicas e duas laboratoriais para que a montagem seja concluída. Na primeira sessão clínica molda-se o paciente. O paciente é dispensado e na primeira sessão laboratorial é necessário que o molde seja vazado, aguardando-se aproximadamente 40 minutos para a cristalização do gesso e depois, no caso de edentados parciais, confecciona-se a base de registro e o rolete de cera para a obtenção do plano de orientação, o qual, além de outras finalidades, irá proporcionar o tripodismo necessário para a montagem do modelo em articulador. Na segunda sessão 
clínica ajusta-se o plano de orientação na boca do paciente, quanto as suas bordas e dimensão vertical e, somente então, procede-se ao registro do arco facial na face do paciente. Após esta consulta, na segunda sessão laboratorial monta-se o modelo superior no articulador.

Mesmo nos casos totalmente dentados, é possível a introdução de erros durante os procedimentos de moldagem da arcadas dentárias e montagem do modelo de gesso no articulador, desde a própria escolha das moldeiras ou confecção das mesmas (no caso de moldeiras individuais ou funcionais), escolha e manuseio dos materiais de moldagem, antes, durante e depois desse procedimento, vazamento do gesso no molde e, também, aqueles motivados por alterações dimensionais dos veículos macios de transferência do modelo utilizados no garfo do arco facial (cera, cera com pasta zinco-eugenólica, godiva, e outros).

Segundo Heartwell \& Rahn (1974) e Freilich et al. (1992) a godiva, utilizada no garfo do arco facial como meio de transferência do modelo para o articulador, é um material termoplástico, anelástico, imediato e de baixo escoamento que apresenta instabilidade dimensional frente a alterações de temperatura. Necessita ser reembasada pela pasta de óxido de zinco e eugenol para poder aumentar sua fidelidade e dar estabilidade ao modelo de gesso.

Henderson \& Steffel (1979) demonstraram que, as ceras são materiais termoplásticos e muito moles, portanto muito instáveis dimensionalmente. Dependendo de sua extensão, a deformação pode ser facilitada no ato da remoção da boca. Quando estas deformidades forem além de seu limite elástico, tornam-se permanentes, ainda que possam passar despercebidas pelo profissional. São utilizadas na confecção dos roletes de cera e sofrem contrações térmicas consideráveis e algumas delas são facilmente deformadas com a alteração de temperatura a que é 
submetida no interior da cavidade oral. Por isso devem ser sempre reembasadas com pastas de óxido de zinco e eugenol para compensar, segundo os autores, apenas parcialmente suas contrações.

As resinas acrílicas autopolimerizáveis utilizadas nas bases de registro, embora duráveis e fortes, apresentam contração de polimerização de acordo com Phillips (1976). A quantidade dessa contração irá depender das características de cada resina e do volume de material utilizado.

Heartwell \& Rahn (1974); Freilich et al. (1992) e Turano \& Turano (1998) notaram que todos os materiais utilizados para moldagem e para o registro oclusal apresentam uma dissimilaridade na reprodução de detalhes das superfícies oclusais. Por exemplo, o alginato é o material de eleição nas moldagens em prótese parcial removível. Devido a sua viscosidade, sua habilidade em copiar os detalhes de uma face oclusal é inferior àquela conseguida pela pasta de óxido de zinco e eugenol, que é de alto escoamento, utilizada neste caso para estabilizar a godiva e a cera. Esse fato contribui para o aparecimento de erros oclusais na montagem dos modelos de gesso, pela dificuldade em se adaptar o modelo de gesso na superfície da pasta, simplesmente por que não há uma perfeita adaptação entre estas duas superfícies. Além disso, as pastas de óxido de zinco e eugenol, também chamadas zincoeugenólicas, são materiais não termoplásticos, anelásticos e mediatos (levam um tempo para endurecerem). São frágeis e requerem sempre um suporte adequado para não sofrerem fraturas, as quais dificilmente não ocorrem nas porções mais finas ao serem removidas da boca, o que acarreta em sérias dificuldades para se colocar o modelo de gesso sobre ela.

No trabalho de Freilich et al. (1992) ficou demonstrado que existe o deslocamento da base de registro combinada com o rolete de cera, devido não 
somente a resiliência da fibromucosa que recobre o rebordo residual, mas também pela diferença de comportamento entre a fibromucosa e os dentes, já analisados anteriormente, somado as diferenças resultantes das limitações na precisão dimensional dos materiais de moldagem, da resina acrílica, da cera e do gesso.

A fim de evitar-se toda a problemática mencionada acima, Zanetti \& Ribas (1997) estudaram um novo método para simplificação e maior precisão de montagem do modelo de gesso da arcada superior em articuladores, por meio de moldeiras de transferência. Trata-se de um processo de montagem que utiliza um dispositivo com o qual se consegue transferir o molde e os registros da arcada superior do paciente para o articulador numa só etapa, sem necessidade de se confeccionarem bases de prova e planos de orientação, utilização do garfo do arco facial e dos meios macios de transferência do modelo.

Costa (1998) e Costa et al. (1999) também estudando a precisão de montagem dos modelos de gesso nos articuladores, verificaram a existência de alterações posicionais durante os procedimentos para montagem do modelo de gesso no articulador. Os autores analisaram esses desvios de posição do modelo de gesso superior fixado ao garfo de mordida, que foram causados pela formação de uma alavanca (Kneip et al., 1951) devido ao apoio do arco facial sobre a mesa incisal do ramo inferior dos articuladores semi-ajustáveis do tipo arcon, que utilizam o arco facial arbitrário simples, técnica que é preconizada por vários autores (Teteruck \& Lundeen, 1966; Hickey et al., 1967; Parel, 1972; Whitsett et al., 1977; Laing \& Wise, 1978; Kotwal, 1979; Hockel, 1980; Wise, 1982; Zuckerman, 1982, Shillingburg et al., 1983; Carter, 1984; Zuckerman, 1985; Malone \& Koth, 1991; Mohl et al., 1991; Ellis III et al., 1992; Todescan et al., 1998; Manual de Instruções do articulador Whip Mix) e desenvolveram um dispositivo para ser utilizado no arco facial, aumentando-lhe a 
precisão. Esse dispositivo foi empregado nessa pesquisa tanto na técnica convencional como na de transferência direta.

Os resultados obtidos revelam que a técnica direta, conhecida como técnica Zanetti, é a melhor indicação para a transferência das informações posicionais da arcada superior do paciente para o articulador, sendo que a técnica convencional de montagem de modelos de gesso apresenta limitações nessa transferência.

Tendo em vista a experiência adquirida no desenvolvimento desse trabalho, sugerimos que novos estudos sejam realizados visando dar continuidade a linha de pesquisa. 


\section{CONCLUSÕES}

De acordo com a proposição dessa investigação e resultados obtidos, podemos concluir que:

1) a técnica de transferência direta apresenta maior capacidade de reprodução do ângulo formado entre o plano de Frankfurt e o plano oclusal do paciente, permitindo assim, um melhor posicionamento do modelo de gesso no articulador.

2) a técnica convencional é extremamente sensível a vários fatores envolvidos, sendo que sua utilização não permite uma precisão adequada devido à deficiências na estabilidade dimensional dos materiais empregados e no controle dos sistemas de suporte com diferentes comportamentos biomecânicos. 
ANEXOS 


\section{Anexo 1 \\ PARECER DA CEP \\ Processo (protocolo) número 13.019.345}

Trata o presente processo de submissão à Comissão de Ética em Pesquisa (CEP) do projeto de pesquisa do Cirurgião Dentista Rogério Ribas da Costa, professor assistente voluntário da Disciplina de Prótese Total da Faculdade de Odontologia da UNICID. Constam do processo o formulário de encaminhamento devidamente preenchido e assinado, o Projeto de Pesquisa em si, o Curriculum vitae do requerente, a avaliação dos riscos potenciais, o termo de responsabilidade do pesquisador e o modelo do Termo de Consentimento a ser eventualmente assinado pelo sujeito. Segundo o requerente, serão comparadas duas técnicas de montagem de modelo de gesso. Para tanto, serão realizadas vinte moldagens por diferentes profissionais em um único indivíduo; assim determinado para que a variabilidade individual entre sujeitos possa ser descartada. O processo está bem instruído e tendo o solicitante atendido todos os trâmites que essa Comissão requer, e, sobretudo, frente ao fato de que não serão empregados equipamentos e/ou materiais de cunho experimental, de risco incerto, mas sim a utilização de um procedimento de uso clínico corriqueiro cujo manuseio será feito por profissionais qualificados, esse parecerista acredita que o projeto como tal prevê e contempla os princípios éticos que norteiam a experimentação cientifica conforme preconizados por esta CEP. Assim sendo, recomendo seu deferimento por essa Comissão. São Paulo, 29 de Março de 2001.

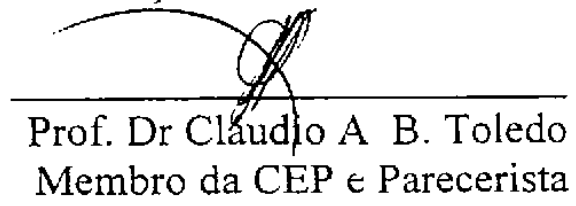

$O$ referido processo foi aprovado por unanimidade na reunião da $\mathrm{CEP}$ realizada no dia 03 de Abril de 2001.

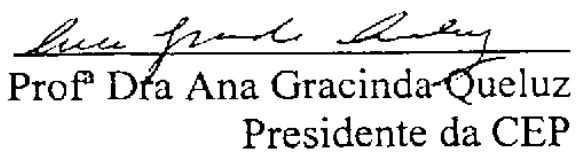




\section{CONSENTIMENTO LIVRE E ESCLARECIDO}

Eu, Edvan Souza Brito, portadora do RG no. 16.371.841, residente a Rua Suzana, 567, CEP 03223-000, fone 6105-8504, paciente do ambulatório de Prótese Dental da Faculdade de Odontologia da UNICID, curso de graduação, aceito participar da pesquisa realizada pelo pósgraduando Mestre Rogério Ribas da Costa, aluno do Curso de PósGraduação da Faculdade de Odontologia da Universidade de São Paulo, que visa comparar 2 diferentes técnicas de montagem de modelos de gesso da arcada superior em articuladores semi-ajustáveis.

Estou ciente que, serão realizadas aproximadamente 25 moldagens em alginato da arcada superior pela técnica de transferência direta para montagem do modelo superior e, também, na mesma arcada, uma moldagem com silicone de adição para obtenção de um modelo-matriz de gesso, para posterior duplicação em 25 modelos de gesso para a montagem pela técnica convencional em articulador, totalizando aproximadamente $\mathbf{4 0}$ montagens com auxílio do arco facial.

Estou ciente ainda que, em determinada fase da pesquisa, serão realizadas fotografias para publicação especializada.

Também estou ciente que nesta pesquisa está garantido o sigilo que assegura a minha privacidade quanto aos dados confidenciais envolvidos.

Ser-me-á garantido o término do tratamento odontológico, mesmo que, a qualquer momento, eu resolva deixar de participar desta pesquisa.

São Paulo, 06 de Abril de 2001

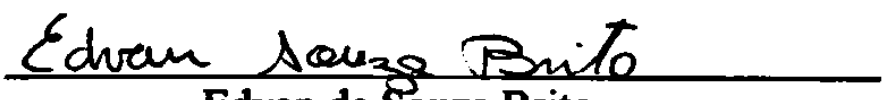

Edvan de Souza Brito

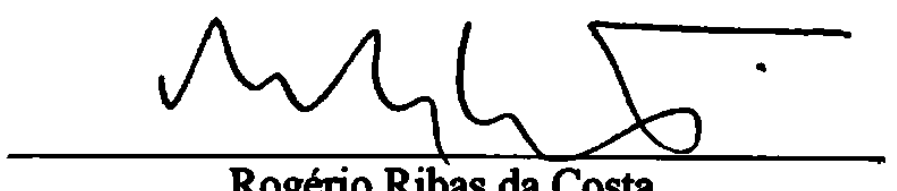

Rogério Ribas da Costa

RG no. 7.954.940

CPF no. 033.805.088-45 


\section{REFERÊNCIAS *}

AKERLY, W. B. Recording jaw relationships in edentulous patients. Dent Clin

North Am, Philadelphia, v. 40, n. 1, p. 53-54, Jan. 1996.

ALTMAN, D. G. Practical statistics in medical research. London: Chapman \& Hall, 1991. 611 p.

ANDERSON, G. C.; SCHULTE, J. K.; ARNOLD, T. G. An in vitro study of an electronic pantograph. J Prosthet Dent, St. Louis, v. 57, n. 5, p. 577-580, May 1987.

APPLEGATE, D. C. Elementos de protesis de dentaduras parciales removibles.

Buenos Aires: Bibliográfica Argentina, 1959.

AULL, A. E. Condylar determinants of occlusal patterns. J Prosthet Dent, St. Louis, v. 15 , n. 5, p. 826-846, Sept./Oct. 1965.

* De acordo com ABNT NBR-6023: 2000. Abreviatura de periódicos segundo Base de Dados MEDLINE. 
BARNETT, F. C. Articulator mounting and adjustments. Aust Orthod J, Brisbane, v. 8, n. 4, p. 128-130, Oct. 1984.

BASSANTA, A. D.; SRNA, M. A. Registros interoclusais e suas interferências na montagem no articulador. Rev Inst Ciênc Saúde, São Paulo, v. 14, n. 2, p. 87-91, jul./dez. 1996.

BEARD, C. C.; CLAYTON, J. A. Studies on the validity of the terminal hinge axis. J Prosthet Dent, St. Louis, v. 46, n. 2, p. 185-191, Aug. 1981.

BECKETT, L. S. Accurate occlusal relations in partial denture construction. Pak Dent Rev, Lahore, v. 5, n. 1, p. 11-18, Jan. 1955.

BELLANTI, N. D. The significance of articular capabilities. Part I: adjustable vs. semiadjustable articulators. J Prosthet Dent, St. Louis, v. 29, n. 3, p. 269-275, Mar. 1973.

BERGSTRÖM, C. On the reproduction of dental articulation by means of articulators: a kinematic investigation. Orebo: A. B. Littorin Ryden, 1950. BIAGI, A.; ELBRECH, H. I. Prótesis articuladas y sus indicaciones. Buenos Aires: Mundi, 1955.

BONFANTE, G.; JANSON, W. A.; PASSANEZI, E.; MORAES, N. Estudo comparativo dos registros do eixo terminal de rotação, determinado por técnicas 
arbitrária e cinemática, no articulador Whip-Mix. Estomatol Cult, Bauru, v. 8, n. 2, p. 173-183, jul./dez. 1974.

BOWLEY, J. F.; BOWMAN, H. C. Evaluation of variables associated with transverse horizontal axis. J Prosthet Dent, St.Louis, v. 68, n. 3, p. 537-541, Sept. 1992.

BOWLEY, J. F.; MORGANO, S. M. Occlusal plane discrepancies generated by transverse horizontal axis deviations. J Prosthet Dent, St. Louis, v. 86, n. 1, p. 67-73, July 2001.

BREEDING, L. C.; DIXON, D. L.; MOSELEY, J. P. Custom impression trays: Part I - Mechanical properties. J Prosthet Dent, St. Louis, v. 71, n. 1, p. 31-34, Jan. 1994.

BUSSAB, W. O.; MORETTIN, P. A. Estatística básica. 4ª ed. São Paulo: Atual Editora, 1987. $321 \mathrm{p}$.

CARTER, R. N. Quick-mounted diagnostic study models. J Clin Orthod, Hempstead, v. 18, n. 6, p. 423-426, June 1984.

CASTLE, A. L.; ANTHONY, T. H. Comparing vertical dimension changes with and without a face-bow transfer. J Dent Technol, Alexandria, v. 15, n. 1, p. 23-25, Jan./Feb. 1998.

CELENZA, F. V. Un analisis de los articuladores. Dent Clin North Am, Philadelphia, v. 2, n. 1, p. 305-326, 1979. 
CHOW, T. W.; CLARK, R. K. F.; COOKE, M. S. Errors in mounting maxillary casts using face-bow records as a result of an anatomical variation. J Dent, Bristol, v. 13, n. 4, p. 277-282, Dec. 1985 .

COSTA, R. R. Estudo da alteração de precisão de montagem do modelo superior em articulador semi-ajustável por meio do arco facial simples. $1998.94 \mathrm{f}$. Dissertação (Mestrado em Prótese Dentária) - Faculdade de Odontologia da Universidade de São Paulo, São Paulo.

COSTA, R. R.; ZANETTI, A. L.; LAGANÁ, D. C.; INOUE, R. T. Estudo da alteração de precisão de montagem do modelo superior em articulador semi-ajustável por meio do arco facial simples. RPG, São Paulo, v. 6, n. 1, p. 88-96, jan./mar. 1999.

DAWSON, P. E. New definition for relating occlusion to varying conditions of the temporomandibular joint. J Prosthet Dent, St. Louis, v. 74, n. 6, p. 619-627, Dec. 1995.

DESPLATS, E. M. La protesis parcial removible en la practica diaria. Barcelona: Labor, 1986. p. 263-302.

DILTS, W. E.; DUNCANSON, M. G.; COLLARD, E. W. Comparative stability of cast mounting materials. J Okla Dent Assoc, Oklahoma, v. 68, n. 4, p. 11-13, Apr. 1978. 
DRAGO, C. J.; RUGH, J. D. Measurement of vertical jaw relationship. In:

LUNDEEN, H. C.; GIBBS, C. H. Advances in occlusion. Bristol: John Wright-PSG, 1982. p. 174-181.

ELLEDGE, D. A.; THEISEN, F. C.; AMET, E. M.; HART, W. K. Secure mounting of diagnosis casts. J Prosthet Dent, Philadelphia, v. 61, n. 4, p. 519-520, Apr. 1989.

ELLIS III, E.; THARANON, W.; GAMBRELL, K. Accuracy of face-bow transfer: effect on surgical prediction and postsurgical result. J Oral Maxillofac Surg, Philadelphia, v. 50, n. 6, p. 562-567, June 1992.

FAVA, P. Conceitos biomecânicos e aparelhos parciais móveis de Beat-Miller. In: ALDROVANDI, C. Prótese parcial móvel. Rio de Janeiro: Científica, 1956. 181 p.

FERREIRA, F. V. Ortodontia: diagnóstico e planejamento clínico. $4^{\mathrm{a}}$ ed. São Paulo: Artes Médicas, 2001. 503 p.

FOX, S. S. The significance of errors in hinge axis location. J Am Dent Assoc, Chicago, v. 74, p. 1268-1272, May 1967.

FREILICH, M. A.; ALTIERI, J. V.; WAHLE, J. J. Principles for selecting interocclusal records for articulation of dentate and partially dentate casts. J Prosthet Dent, St. Louis, v. 68, n. 2, p. 361-367, Aug. 1992. 
GIBBS, C. H.; LUNDEEN, H. C. Jaw movements and forces during chewing and swallowing and their clinical significance. In: LUNDEEN, H. C.; GIBBS, C. H. Advances in occlusion. Bristol: John Wright-PSG, 1982. p. 2-29.

GORDON, S. R.; STOFFER, W. M. Technique for transferring information from a pantograph tracing to semiadjustable articulators. J Prosthet Dent, St. Louis, v. 54, n. 4, p. 503-507, Oct. 1985.

GORDON, S. R.; STOFFER, W. M.; CONNOR, S. A. Location of the terminal hinge axis and its effect on the second molar cusp position. J Prosthet Dent, St. Louis, v. 52, n. 1, p. 99-105, 1984.

GOSKA, J. R.; CHRISTENSEN, L. V. Comparision of cast positions by using four face-bows. J Prosthet Dent, St. Louis., v. 59, n. 1, p. 42-44, Jan. 1988.

GRANT, A. A. Elevation of the incisal guide pin following attachment of casts to articulators. J Prosthet Dent, St. Louis, v. 13, n. 4, p. 664-675, July/Aug. 1963.

GROSS, M. D.; GAZIT, E. Articulators used in North american dental schools. J Dent Educ, San Francisco, v. 49,n. 10, p. 710-711, Oct. 1985.

GROSS, M. D.; NEMCOVSKY, C.; FRIEDLANDER, L. D. Comparative study of condylar settings of three semiadjustable articulators. Int J Prosthodont, Lombard, v. 3, n. 2, p. 135-141, Mar./Apr. 1990. 
HART, T. D.; MALONE, W. F.; SANDRICK, J.; BOWMAN, D.; BALTHAZAR, Y. M. A proposed format for mandibular displacement analysis in fixed prosthodontics. J Prosthet Dent, St. Louis, v. 50, n. 1, p. 54-61, 1983.

HAYASHI, T.; SAITOH, A.; ISHIOKA, K.; MIYAKAWA, M. A computerized system for analyzing occlusal relations during mandibular movements. Int J Prosthodont, Lombard, v. 7, n. 2, p. 108-114, Mar./Apr. 1994.

HEARTWELL, C. M; RAHN, A. O. Syllabus of complete dentures. $2^{\text {a }}$ ed. Philadelphia: Lea \& Febiger, 1974. p. 47, 77, 202.

HENDERSON, D., STEFFEL, V. L. Prótese parcial removível de McCracken. São Paulo: Artes Médicas, 1979. p. 15-8; 105-20; 165-201; 273-321.

HICKEY, J. C.; LUNDEEN, H. C.; BOHANNAN, H. M. A new articulator for use in teaching and general practice. J Prosthet Dent, St. Louis, v. 18, n. 5, p. 425-437, Nov. 1967.

HOBO, S.; SHILLINGBURG, H. T.; WHITSETT, L. D. Articulator selection for restorative dentistry. J Prosthet Dent, St. Louis, v. 36, v. 1, p. 35-42, July 1976.

HOCKEL, J. L. The face bow: A primary diagnostic aid to gaining an organic occlusion, the goal of orthopedic gnathology. Int J Orthod, Lakewood, v. 18, n. 2, p. 13-16, June 1980. 
HUGGETT, R.; HARRISON, A. Antagonizers 1805 to articulators 1977. Dent Tech, London, v. 30, n. 7, p. 4-7, July 1977.

JOHNSON, D. L.; STRATTON, R. J. Fundamentos da prótese removível. Rio de Janeiro: Quintessence, 1988. p. 167-190, 245-8.

JONES, G. L. A method of teaching face-bow transfer. J Dent Educ, San Francisco, v. 38 , n. 10 , p. 558-560, Oct. 1974.

KAFANDARIS, N. M.; THEODOROU, P. T. Modification of a semiadjustable articulator to accept the patient's intercondilar width. J Prosthet Dent, St. Louis, v. 48, n. 4, p. 385-387, Oct. 1982.

KNEIP, K.; WINZER, G.; KILLMANN, P. La escuela del técnico mecánico. Tomo III: mecánica resistencia de materiales grafostática. $3^{\mathrm{a}}$ ed. Barcelona: Labor, 1951. p.78-90 e 166-171.

KOLLING, J. N.; PRICE, R. B.; MILLER, R. L.; CLAYTON, J. A. Evaluation of a digitizer and computer system designed to analyze articulator-generated occlusal tracings. J Prosthet Dent, St. Louis, v. 59, n. 4, p. 499-503, Apr. 1988.

KOTWAL, K. R. The need to use an arbitrary face-bow when remounting complete dentures with interoclusal records. J Prosthet Dent, St. Louis, v. 42, n. 2, p. 224-227, Aug. 1979. 
LAING, D. P.; WISE, M. D. Split cast discrepancies and arbitrary axis dental cast articulator mounting. J Oral Rehabil, Oxford, v. 5, n. 3, p. 249-259, July 1978.

LEKNIUS, C. Structural improvement of an electronic pantograph stylus assembly. J Prosthet Dent, St. Louis, v. 76, n. 3, p. 339, Sept. 1996.

LOOS, L. G. One face-bow adapts to three articulators. J Prosthet Dent, St. Louis, v. 39, n. 4, p. 469-472, Apr. 1978.

MACHADO, M. S. S. Métodos e meios para o registro cêntrico da relação maxilomandibular em pacientes parcialmente edentados com vistas à prótese parcial removível. 1992. 70 f. Dissertação (Mestrado em Prótese Dentária) Faculdade de Odontologia da Universidade de São Paulo, São Paulo.

MALONE, W. F.; KOTH, D. Teoria e prática de prótese fixa de Tylman. $8^{\mathrm{a}}$ ed. São Paulo: Artes Médicas, 1991. p. 371-79.

McCOLLUM, B. B. Fundamentals involved in prescribing restorative dental remedies. Dent Items Interest, Philadelphia, v. 61, n. 9, p. 641-648; 724-36; 852-63; 942-50, 1939.

McCRACKEN, W. L. Occlusal in partial denture prosthesis. Dent Clin North Am, Philadelphia, v. 12, n. 3, p. 311-313, Mar. 1962. 
MENDEZ, A. J. The influence of imprssion trays on the accuracy of stone casts poured from irreversible hydroccoloid impressions. J Prosthet Dent, St. Louis, v. 54, n. 3, p. 383-388, Sept. 1985.

MILLER, E. L. Removable partial prosthodontics. Baltimore: Williams \& Wilkins, 1972, p. 210-230.

MITCHELL, D. L.; WILKIE, N. D. Articulators through the years. Part I. Up to 1940. J Prosthet Dent, St. Louis, v. 30, n. 3, p. 330-338, Mar. 1978.

MOBERG, C. T.; YODER, J. L.; THAYER, K. E. The pantograph as a face-bow transfer instrument. J Prosthet Dent, St. Louis, v. 29, n. 2, p. 139-145, Feb. 1973.

MOHAMED, S. E.; SCHMIDT, J. R.; HARRISON, J. D. Articulators in dental education and practice. J Prosthet Dent, St. Louis, v. 36, n. 3, p. 319-325, Sept. 1976.

MOHL, N. D.; ZARB, G. A.; CARLSSON, G. E.; RUGH, J. D. Fundamentos de oclusão. $2^{\mathrm{a}}$ ed. Rio de Janeiro: Quintessence, 1991. p. 154-159.

MONGINI, F. Occlusion and the temporomandibular joint. In: LUNDEEN, H. C.; GIBBS, C. H. Advances in occlusion. Bristol: John Wright-PSG, 1982. p. 100-103.

OGESEN, R. B. Construction of free-end saddle partial dentures. Dent Dig, Pittsburgh, v. 74, n. 9, p. 381-385, Sept. 1968. 
OSBORNE, J.; LAMMIE, G. A. Removable partial denture. London: Blackwell, 1968. p. 346-366.

PALIK, J. F.; NELSON, D. R.; WHITE, J. T. Accuracy of an earpiece face-bow. J Prosthet Dent, St. Louis, v. 53, n. 6, . 800-804, June 1985.

PAREL, S. M. Using the Whip-Mix face-bow with condylar articulators. J Prosthet Dent, St. Louis, v. 28, n. 2, p. 200-204, Aug. 1972.

PEREGRINA, A.; FEIL, P. H. Reproducibility of occlusal contacts relative to mounting cast variables. J Prosthet Dent, St. Louis, v 25, n. 9, p. 617-619, Sept. 1994.

PHILLIPS, R. W. La ciencia de los materiales dentales de Skinner. $1^{\mathrm{a}}$ ed. México: Interamericana, $1976.583 \mathrm{p}$.

PIEHSLINGER, E.; BAUER, W.; SCHMIEDMAYER, H. B. Computer simulation of occlusal discrepancies resulting from different mounting techniques. J Prosthet Dent, St. Louis, v. 74, n. 3, p. 279-283, Sept. 1985.

PITCHFORD, J. H. A reevaluation of the axis-orbital plane and the use of orbitale in facebow transfer record. J Prosthet Dent, St. Louis, v. 66, n. 3, p. 349-355, Sept. 1991. 
POSSELT, U. Physiology of occlusion and rehabilitation. $2^{\text {a }}$ ed. Oxford:

Blackwell Scientific, 1968. 331 p.

PRUDEN, W. H. The role of study casts in diagnosis and treatment planning. J

Prosthet Dent, St. Louis, v.10, n.4, p.707-710, July 1960.

RAMFJORD, S.; ASH, M. M. Oclusão. Rio de Janeiro: Editora Guanabara, 1983. p. 212-227.

RAZEK, M. K. A. Clinical evaluation of methods used in locating the mandibular hinge axis. J Prosthet Dent, St. Louis, v. 46, n. 4, p. 369-372, Oct. 1981.

REBOSSIO, A. D. Prótesis parcial removible. Buenos Aires: Mundi, 1963, 662 p.

RIHANI, A. Classification of articulators. J Prosthet Dent, St. Louis, v. 43, n. 3, p. 344-347, Mar. 1980.

RORAFF, A. R.; STANSBURY, B. E. Errors caused by dimensional change in mounting material. J Prosthet Dent, St. Louis, v. 28, n. 3, p. 247-252, Sept. 1972.

RUDD, K. D.; MORROW, R. M.; EISSMAN, H. F. Dental laboratory procedures removable partial denture. St. Louis: Mosby, 1981. p. 72-129. 
SANTOS Jr., J.; NELSON, S. J.; NUMMIKOSKI, P. Geometric analysis of occlusal plane orientation using simulated ear-rod facebow transfer. J Prosthodont, St. Louis, v. 5, n. 3, Sept. 1996.

SHARRY, J. J. Complete denture prosthodontics. $3^{\text {a }}$ ed. New York: McGraw-Hill Book, 1974. p. 222-224.

SHILlingBURG, H. T.; HOBO, S.; WHITSETT, L. D. Fundamentos de prótese fixa. São Paulo: Editora Santos, 1983. p. 207-228.

SMITH, D. E. Does one articulator meet the needs for both fixed and removable prosthodontics? J Prosthet Dent, St. Louis, v. 54, n. 2, p. 296-302, Aug. 1985.

SMUTKO, G. E. Making edentulous impressions. Dent Clin North Am, Philadelphia, v. 21, n. 2, p. 261-269, Apr. 1977.

STADE, E. H.; HANSON, J. G.; BAKER, C. L. Esthetic considerations in the use of face-bows. J Prosthet Dent, St. Louis, v. 48, n. 3, p. 253-256, Sept. 1982.

STROHAVER, R. A.; RYAN, J. R. New face-bow simplifies routine use and dental laboratory cooperation. J Prosthet Dent, St. Louis, v. 60, n. 5, p. 638-641, Nov. 1988.

SWENSON, M. G.; TERKLA, L. G. Construcción de dentaduras parciales. Rosário: La Médica, 1958, p. 153-179. 
TAMAKI, N.; YAMADA, M. C. M.; TAMAKI, S. T.; TAMAKI, T. Variações posicionais dos modelos no articulador com bases no eixo terminal de rotação e pontos condilares anatômicos. Rev Odontol Univ São Paulo, São Paulo, v. 4, n. 3, p. 206-211, jul./set. 1990.

TAMAKI, S. T. Calibragem do articulador: estudo comparativo de 3 técnicas. 1976. 111 f. Tese (Livre-Docência em Prótese Dentária) Faculdade de Odontologia da Universidade de São Paulo, São Paulo.

TAMAKI, T. ATM: noções de interêsse protético. São Paulo: Sarvier. 1981. 148 p.

TANAKA, H.; FINGER, I. M. A new semiadjustable articulator. Part IV: an investigation of three semiadjustable articulators. J Prosthet Dent, St. Louis, v. 40, n. 3, p. 288-293, Sept. 1978.

TANAKA, H.; FINGER, I.; PORTER, M. M. J. A new semiadjustable articulator. Part II: adjustment of a new-concept articulator. J Prosthet Dent, St. Louis,. v. 33, n. 2, p. 158-167, Feb. 1975.

TERKLA, L. G.; LANEY, W. R. Partial dentures. St. Louis: Mosby, 1963. p. 112121.

TETERUCK, W. R.; LUNDEEN, H. C. The accuracy of an ear face-bow. J Prosthet Dent, St. Louis, v. 16, n. 6, p. 1039-1046, Nov./Dec. 1966. 
THOMAS, C. J. A classification of articulators. J Prosthet Dent, St. Louis, v. 30, n. 1, p. 11-14, Sept. /Oct. 1973.

THORP, E. R.; SMITH, D. E.; NICHOLLS, J. I. Evaluation of the use of a face-bow in complete denture occlusion. J Prosthet Dent, St. Louis, v. 39, v. 1, p. 5-15, Jan. 1978.

TODESCAN, R.; SILVA, E. E. B.; SILVA, O. J. Atlas de prótese parcial removível. São Paulo: Editora Santos, 1998. p. 278-282.

TURANO, J. C.; TURANO, L. M. Fundamentos de prótese total. $4^{\mathrm{a}}$ ed. São Paulo: Quintessence, 1998. 560 p.

VALDERHAUG, J.; FL $\phi$ YSTRAND, F. Dimensional stability of elastomeric impression materials in custom-made and stock trays. J Prosthet Dent, St. Louis, v. 52, n. 4, p. 514-517, Oct. 1984.

WALKER, P. M. Discrepancies between arbitrary and true hinge axes. J Prosthet Dent, St. Louis, v. 43, n. 3, p. 279-285, Mar. 1980.

WEINBERG, L. A. An evaluation of basic articulators and their concepts. Part I: basic concepts. J Prosthet Dent, St. Louis, v. 13, n. 4, p. 622-644. July/Aug. 1963a. 
WEINBERG, L. A. An evaluation of basic articulators and their concepts. Part II:

arbitrary, positional, semiadjustable articulators. J Prosthet Dent, St. Louis, v. 13, n. 4, p. 645-663. July/Aug. 1963 b.

WEINBERG, L. A. An evaluation of of the face-bow mounting. J Prosthet Dent, St. Louis, v. 11, p. 32-42. 1961.

WhITBECK, P.; IVANHOE, J. R. Occlusal relationship. Dent Clin North Am, Philadelphia, v. 29, n. 1, p. 149-162, Jan. 1985.

WHITSETT, L. D.; SHILLINGBURG, H. T.; KEENAN, M. P. Modifications of a new semi-ajustable for use with a caliper style ear face-bow. J Calif Dent Assoc, Sacramento, v. 5, n. 4, p. 32-38, Apr. 1977.

WINSTANLEY, R. B. The hinge-axis: a review of the literature. J Oral Rehabil, Oxford, v. 12, n. 2, p. 135-159, Mar. 1985.

WISE, M. D. Occlusion and restorative dentistry for the general practicioner. Br Dent J, London, v. 152, n. 8, p. 277-287, Apr. 1982.

WRIGHT Jr., W. J. A mathematical method for calculating the compensating anterior stop pin setting of a semiadjustable arcon articulator. J Prosthet Dent, St. Louis, v. 61, n. 3, p. 362-367, Mar. 1989. 
ZANETTI, A. L.; LAGANÁ, D. C. Planejamento: prótese parcial removível. $2^{\mathrm{a}}$ Ed. São Paulo: Sarvier, 1996. 147 p.

ZANETTI, A. L.; RIBAS, R. A new method to simplify and increase the precision of maxillary cast mounting procedures in fully adjustable or semiadjustable articulators. J Prosthet Dent, St. Louis, v. 77, n. 2, p. 219-224, Feb. 1997.

ZANETTI, A. L.; RIBAS, R. Um novo método para simplificação e maior precisão de montagem de modelos de arcos superiores em articuladores semi ou totalmente ajustáveis. Rev Odontol UNICID, São Paulo, v. 8, n. 1, p. 15-24, jan./jun. 1996.

ZINNER, I. D. Impression procedures for the removable component of a combination fixed na removable prosthesis. Dent Clin North Am, Philadelphia, v. 31, n. 3, p. $417-$ 440, July 1987.

ZUCKERMAN, G. R. The geometry of the arbitrary hinge axis as it relates to the occlusion. J Prosthet Dent, St. Louis, v. 48, n. 6, p. 725-733, Dec. 1982.

ZUCKERMAN, G.R. Practical considerations for using the face-bow for complete denture prosthodontics. J Prosthet Dent, St. Louis, v. 53, n. 2, p. 219-221, Feb. 1985. 


\section{A COMPARATIVE STUDY BETWEEN TWO TECHNIQUES TO MOUNT THE MAXILLARY CAST IN SEMI-ADJUSTABLE}

\section{ARTICULATOR}

This study assessed the ability of two techniques to mount the maxillary cast in the articulator, a conventional technique and one of direct transfer of the maxillary arch impression from the patient's mouth to the articulator. A single female subject, 39 years old, with a partially edentulous arch, Kennedy's Class I, was used in this investigation. It was obtained 20 casts in each technique, totaling 40 cast mountings in the articulators. With the maxillary cast mounted, each articulator was photographed in the same right side of the lateral skull cephalometric radiograph of the patient with the face-bow mounted in her face. The measures obtained by the photographic and cephalometric tracings were evaluated by calculating the angle made by the intersection of the maxillary occlusal plane with craniofacial horizontal reference plane (Frankfort's plane) on the patient's cephalogram and comparing it with the angle between the occlusal plane of the cast with the upper member of the articulators in both techniques using the UTHSCSA Image Tool computerized program. The measuring data was submitted to the statistical analysis. The results of this study demonstrated a better capacity of reproduction of that angle when a direct transfer technique is used. In the same way, it was found a significant low level of reproducibility in mounting the maxillary cast when a conventional technique is used. 


\section{AUTORIZAÇÃO}

Autorizo a reprodução e/ou divulgação total ou parcial da presente obra, por qualquer meio convencional ou eletrônico, desde que citada a fonte e comunicada, ao autor, a referência bibliográfica em que consta a citação.

\section{ROGÉRIO RIBAS DA COSTA}

São Paulo, 20 de Novembro de 2001.

Faculdade de Odontologia da Universidade de São Paulo.

Av. Lineu Prestes, 2227 - Cidade Universitária.

05508-900 São Paulo - Capital - Brasil.

e-mail: rogerio.ribas.cd@gmail.com 